\title{
Información Importante
}

La Universidad Santo Tomás, informa que el(los) autor(es) ha(n) autorizado a usuarios internos y externos de la institución a consultar el contenido de este documento a través del Catálogo en línea del CRAI-Biblioteca y el Repositorio Institucional en la página Web de la CRAI-Biblioteca, así como en las redes de información del país y del exterior con las cuales tenga convenio la Universidad.

Se permite la consulta a los usuarios interesados en el contenido de este documento, para todos los usos que tengan finalidad académica, nunca para usos comerciales, siempre y cuando mediante la correspondiente cita bibliográfica se le dé crédito al trabajo de grado y a su autor.

De conformidad con lo establecido en el Artículo 30 de la Ley 23 de 1982 y elartículo 11 de la Decisión Andina 351 de 1993, la Universidad Santo Tomás informa que "los derechos morales sobre documento son propiedad de los autores, los cuales son irrenunciables, imprescriptibles, inembargables e inalienables."

Centro de Recursos para el Aprendizaje y la Investigación, CRAI-Biblioteca Universidad Santo Tomás, Bucaramanga 
El abuso del derecho y el desconocimiento de la buena fe en las relaciones contractuales de la Empresa Colombiana de Petróleos S.A.

Luz Beatriz Pineda Ramírez

Trabajo de grado presentado para optar al título de Magister en Derecho

\section{Director:}

\section{Manuel Dubian Estupiñan}

Magister

Universidad Santo Tomás, Bucaramanga

Facultad De Derecho

Maestría En Derecho 


\section{Tabla de contenido}

Introducción 8

1. Descripción del problema de investigación ............................................................... 10

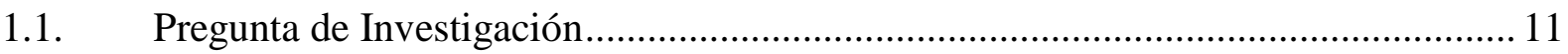

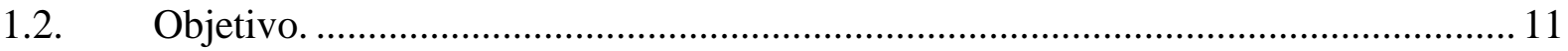

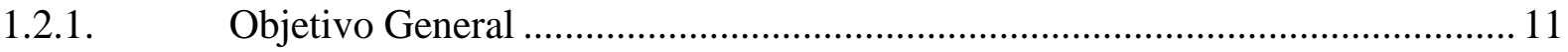

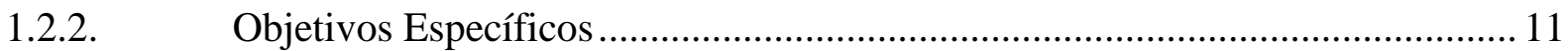

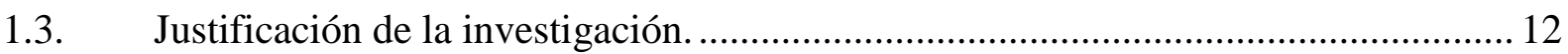

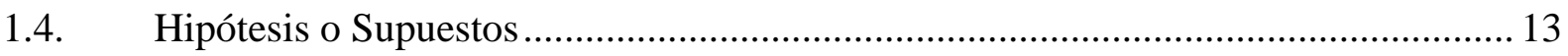

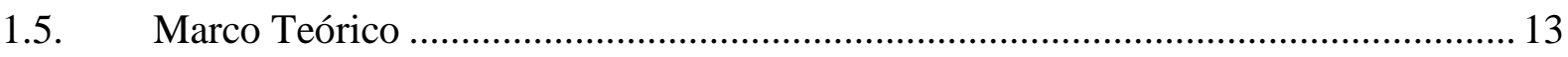

1.6. La buena fe en sentido subjetivo y objetivo ......................................................... 17

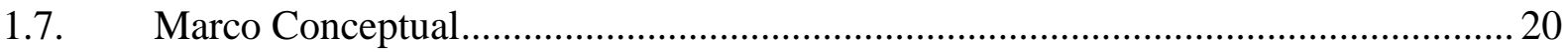

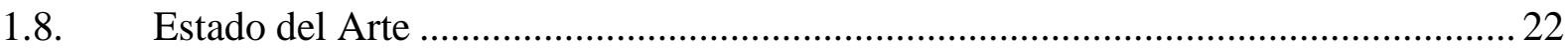

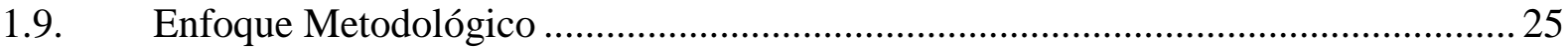

2. El principio de la buena fe en Colombia........................................................................ 26

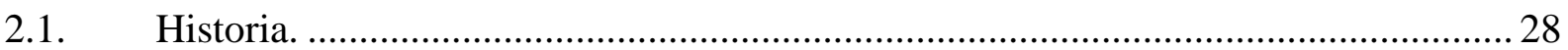

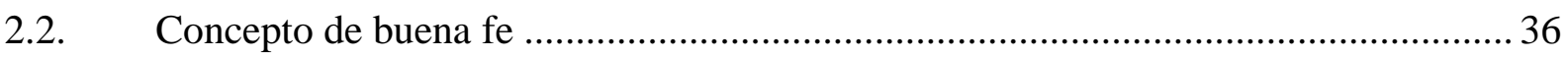

2.3. Diferentes conceptos que derivan de la buena fe como principio ............................ 39

2.4. Principio de buena fe en las actuaciones de la administración ................................. 48

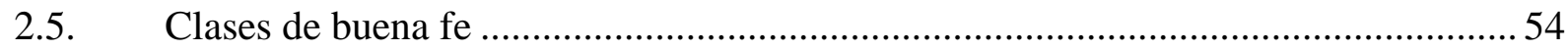

2.6. Principio de la buena fe en la teoría del contrato ....................................................59

2.7. Pronunciamientos Jurisprudenciales sobre el Principio de la Buena Fe ................. 63

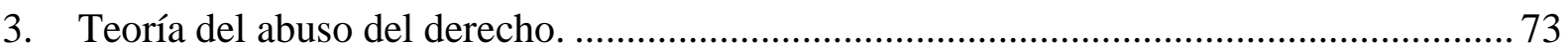

3.1. Características para que exista el Abuso de Derecho. ............................................. 74

3.2. Criterios para la clasificación del Abuso de Derecho............................................. 77

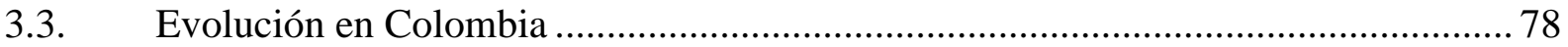

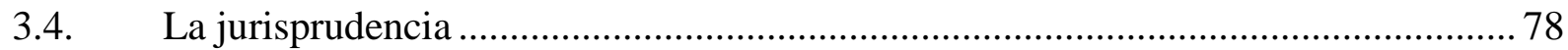

3.4.1 Procesos en los cuales se denota El Abuso del Derecho en la Jurisprudencia de la Corte Suprema de Justicia.

4. Ecopetrol: un caso representativo de abuso del derecho por desconocimiento del principio de la buena fe en el marco de algunas de sus relaciones contractuales.................................. 89

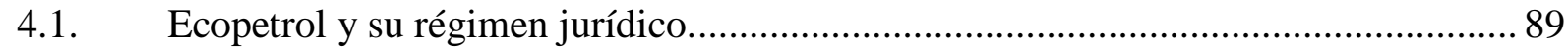

4.2. Manual de Contratación de ECOPETROL S.A........................................................ 91

4.3. Definición de Retención en Garantía....................................................................... 91 
4.4. Casos en los que se constata el abuso del derecho y violación del principio de la buena fe.

\subsubsection{Contrato MA-0018531 suscrito entre ECOPETROL S.A. y la UNIÓN TEMPORAL} PLATAFORMAS PETROLERAS X para el montaje y construcción de facilidades de superficie para proyectos de producción y exploración en la GCO y campos menores asociados a la gerencia.

\subsubsection{Contrato MA-0020935 suscrito entre ECOPETROL S.A. y el CONSORCIO}

PLATAFORMAS PETROLERAS XIV cuyo objeto es "Obras civiles de realce y rehabilitación de los puntos críticos entre el K1+160 al K11+000 en el dique marginal que protege el municipio de Yondo (Antioquia), en el campo casabe de la gerencia regional magdalena medio de Ecopetrol S.A.”.

4.4.3. Otros casos en los que se constata el abuso del derecho y violación del principio de la buena fe reduciendo la utilidad del contratista.

4.5. Sobre las cláusulas excepcionales o exorbitantes previstas en el Estatuto General de Contratación Estatal, y su aplicación en los contratos sometidos a las reglas de derecho privado en los que haga parte una entidad estatal

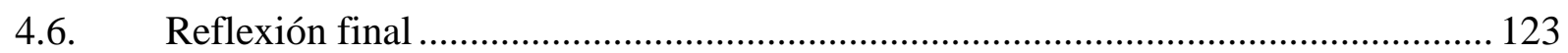

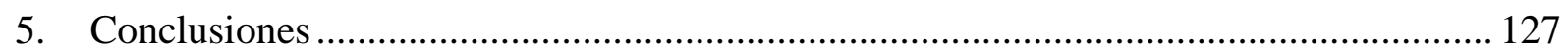

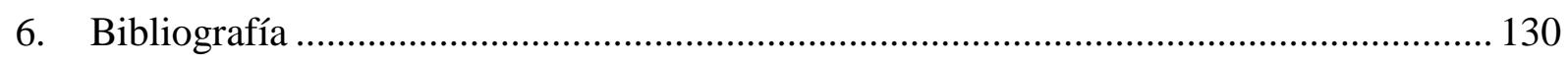

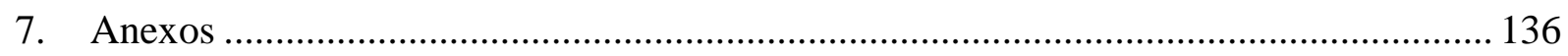




\section{Lista de tablas}

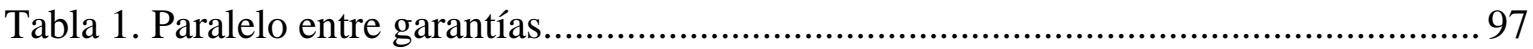




\section{Lista de figura}

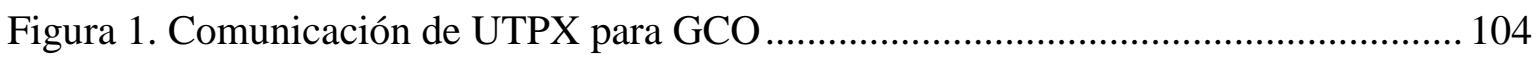

Figura 2. Comunicación de Ecopetrol para UTPX ..................................................... 105

Figura 3. Certificación de cumplimiento de perfiles........................................................ 108

Figura 4. Evidencia electrónica de aceptación de pago...................................................... 109 


\section{Lista de Apéndices}

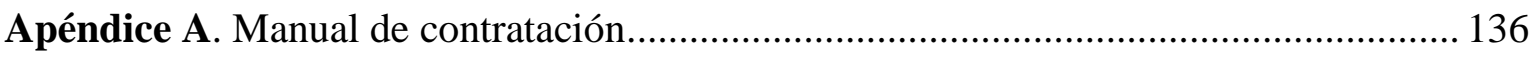

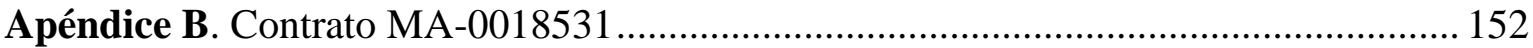




\section{Introducción}

Para Valencia Zea y Ortiz Monsalve (2006: 212-213), la buena fe indica que cada cual debe celebrar sus negocios, cumplir sus obligaciones y, en general, ejercer sus derechos, mediante el empleo de una "conducta de fidelidad, o sea, por medio de la lealtad y sinceridad que imperan en una comunidad de hombres dotados de criterio honesto y razonable".

La buena fe es un principio general del derecho y su validez en todo el ámbito jurídico es incuestionable. Por ello y para entender mejor la cuestión se empieza por considerar a la buena fe como un principio general de derecho, aplicable en el ámbito de las relaciones entre los particulares. Al reivindicar su condición de principio general, presupone que es anterior y está por encima de la legislación positiva y que, en razón a ello, permea todo el sistema jurídico.

$\mathrm{Al}$ respecto, se sostiene que dicho principio es exigible en la expedición de actos jurídicos, en el ejercicio de derechos y en el cumplimiento de las obligaciones. Por esa razón, se precisa que a pesar de su consagración en una norma legal, ello no supone que con anterioridad no existiera, ni que por tal consagración legislativa haya perdido el carácter de principio; ya que esta categoría jurídica, por su propia naturaleza, existe con independencia de su regulación en una norma en forma de regla. Esta última circunstancia se constituirá en una herramienta más de su pleno reconocimiento, pero no en el elemento determinante.

Lo anterior ha sido acogido ampliamente por la Honorable Corte Constitucional, que no ha dudado en calificar la buena fe como un principio general de derecho, de indiscutible aplicabilidad en el sistema en cuanto a la contratación privada. Para este efecto señala unos parámetros, que están llamados a cumplir en el sistema normativo los siguientes roles: 1) 
sirven de base y fundamento de todo el ordenamiento jurídico; 2) actúan como directriz hermenéutica para la aplicación de las reglas jurídicas; y finalmente, 3) en caso de insuficiencia normativa concreta y específica, se emplean como fuente integradora del derecho. En estos términos, es indiscutible que los principios cumplen una triple función de fundamento, interpretación e integración del orden jurídico (Escobar Gil, 2005) y, en el caso de la prohibición del abuso del derecho, se advierte la existencia de otro verdadero principio que, al igual que el de la buena fe, cumple con la triple función antes referida.

Tanto los particulares como las autoridades públicas, a través de los servidores públicos que las encarnan, están obligados a actuar de conformidad con los dictados del principio general de la buena fe, esto es, con lealtad, transparencia y honestidad y a no abusar de los derechos ajenos. Dicho deber se pone de manifiesto en la celebración y ejecución de actos jurídicos, en el disfrute de derechos, en el cumplimiento de obligaciones y en el ejercicio de potestades o prerrogativas, según se trate. Esa meridiana claridad sobre los alcances del artículo 83 de la C.N. se vuelve problemática al analizar la aplicabilidad de la presunción allí establecida en escenarios contractuales en los que al parecer impera la desconfianza y en los que termina imponiéndose la voluntad de una de las partes, como puede observarse en el caso de ECOPETROL, cuando exige pólizas de seguro, fundado en criterios desacertados de desconfianza y con base en riesgos que no lo acechan en sana lógica, pues -a manera de ejemplo- el pago de salarios, prestaciones sociales e indemnizaciones laborales a quienes son vinculados para la ejecución del contrato es un asunto entre el contratista y sus trabajadores, respecto al cual Ecopetrol no debería inmiscuirse si realmente concibiera el principio de la buena fe como se desarrolla en este trabajo.

De igual forma, resulta abusivo y contrario a la buena fe que el cambio o sustitución del personal vinculado para la ejecución del contrato deba ser autorizado previamente por 
Ecopetrol y que esta empresa además se arrogue el derecho de ser la única en determinar la idoneidad del personal del contratista, como si este no supiera seleccionar su propio personal.

Con este contexto, el presente proyecto busca demostrar que en algunos casos la Empresa Colombiana de Petróleos S.A. abusa del derecho por desconocer el principio de la buena fe en sus relaciones contractuales, utilizando referentes casuísticos, con el fin de revindicar la importancia de respetar aquel principio. Para ello se parte analizando la naturaleza y el contenido del principio de la buena fe en Colombia, para seguidamente estudiar la teoría del abuso del derecho y terminar acreditando cómo en algunos casos la Empresa Colombiana de Petróleos S.A. abusa del derecho por desconocer el principio de la buena fe en relaciones contractuales concretas.

\section{Descripción del problema de investigación}

La buena fe no hace presencia en algunas relaciones contractuales de la Empresa Colombiana de Petróleos S.A., por el contrario reina la desconfianza y el abuso del derecho, situación que resulta preocupante comoquiera que la Constitución Política prohíbe el ejercicio abusivo de los derechos -artículo 95- y presume la buena fe -artículo 83-. Existen casos concretos, es decir contratos específicos, en los que se puede constatar que la empresa más importante de Colombia, en materia de hidrocarburos, abusa de su posición dominante y desconoce la buena fe en sus relaciones contractuales, lo que lamentablemente amerita ser rechazado sin ambages, dada la filosofía y axiología que adoptó el constituyente de 1991.

Se trata, pues, de poner de relieve que Ecopetrol no dimensiona el principio de la buena fe en su verdadero sentido y exige al contratista pólizas de seguro innecesarias que le causan a este un detrimento patrimonial, para cubrir riesgos que en poco o nada le representan 
una verdadera amenaza y, además, se arroga el derecho de evaluar su desempeño técnico y administrativo, sin una metodología que garantice la objetividad y su derecho de defensa, como si no fuera suficiente con la experiencia demostrada en el proceso de convocatoria. Adicionalmente, el contratista queda obligado a suscribir cláusulas abusivas y, de quedar mal calificado, pierde futuras oportunidades de contratación, resultando perjudicado en términos de competitividad.

En otras palabras, se irrespeta el equilibrio contractual y se desdibuja el principio de la buena fe contractual como la creencia de estar actuando conforme a la ley y que la conducta que asume la otra persona, la asume también dentro de ese marco. El contratante domina al contratista desde el inicio de la relación contractual, prueba de ello -vale agregar- los formatos y formularios que evidencian la existencia de verdaderos contratos de adhesión, en los que no puede discutirse absolutamente nada.

\subsection{Pregunta de Investigación}

¿Cómo la Empresa Colombiana de Petróleos S.A. abusa del derecho en algunas de sus relaciones contractuales por desconocer el principio de la buena fe?

\subsection{Objetivo.}

\subsubsection{Objetivo General}

Demostrar que la Empresa Colombiana de Petróleos S.A. abusa del derecho en algunas de sus relaciones contractuales por desconocer el principio de la buena fe, utilizando referentes casuísticos, con el fin de revindicar la importancia de respetar aquel principio.

\subsubsection{Objetivos Específicos}

a. Analizar la naturaleza y el contenido del principio de la buena fe.

b. Describir la teoría del abuso del derecho. 
c. Explicar cómo la Empresa Colombiana de Petróleos S.A. abusa del derecho en algunas de sus relaciones contractuales por desconocer el principio de la buena fe.

\subsection{Justificación de la investigación.}

Esta investigación fue realizada porque era imperioso reflexionar sobre el sistemático ejercicio abusivo del derecho que se advierte en algunas relaciones contractuales de la Empresa Colombiana de Petróleos S.A., por causa del desconocimiento del principio de la buena fe. Por ello y con base en referentes casuísticos reales, se consideró necesario hacer énfasis en la importancia de respetar aquel principio.

El principio de la buena fe tiene una importancia en la contratación al ser el fundamento de las relaciones entre el contratante y el contratista, orientando la interpretación de los actos celebrados por los mismos y cimentando la ética moral en los mismos al constituir un límite a la superioridad del contratante frente a la posición patrimonial del contratista que debe cumplir con los parámetros para ejercer sus derechos y deberes. Por tanto, la Empresa Colombiana de Petróleos S.A. desconoce la buena fe y, por ende, abusa del derecho - por ejemplo- cuando fundada en criterios desacertados de desconfianza exige una póliza de seguro con base en riesgos que no la acechan en sana lógica, pues el pago de salarios, prestaciones sociales e indemnizaciones laborales -a quienes son vinculados para la ejecución del contrato- es un asunto exclusivo entre el contratista y sus trabajadores, respecto al cual Ecopetrol no debería inmiscuirse si realmente confiara en que el contratista asumirá con responsabilidad sus obligaciones. De igual forma, resulta abusivo y contrario a la buena fe que el cambio o sustitución del personal vinculado para la ejecución del contrato deba ser autorizado previamente por Ecopetrol y que esta empresa, además, se arrogue el derecho de ser la única en determinar la idoneidad del personal del contratista, como si este no supiera seleccionar su propio personal. 
Es así como pudo constatarse en esta investigación que una inadecuada concepción del principio de la autonomía de la voluntad por parte de la Empresa Colombiana de Petróleos S.A. mengua la buena fe contractual, siendo esta necesaria para el desarrollo mismo del contrato y la cual no puede, por causa del capricho de una de las partes en la relación contractual, ser burlada en el Estado Social de Derecho; ya que ello traería consecuencias negativas para el acuerdo de voluntades, generando incluso la ineficacia de cláusulas contractuales.

Así las cosas, la cuestión abordada en esta investigación resulta pertinente en términos de actualidad y aporte jurídico, pues se trata de un problema real que afecta a miles de contratistas que, día a día, sufren las consecuencias del ejercicio abusivo del derecho por parte de Ecopetrol, situación que justifica -por sí sola- la importancia del presente trabajo. Finalmente, para cumplir los objetivos propuestos, se estudiaron algunos contratos en los que es parte Ecopetrol y en los que se constata un grosero desconocimiento del principio constitucional de la buena fe.

\subsection{Hipótesis o Supuestos}

En algunas de sus relaciones contractuales, la Empresa Colombiana de Petróleos S.A. abusa del derecho por desconocer el principio de la buena fe.

\subsection{Marco Teórico}

La presente investigación se desarrollará a partir de las teorías de la buena fe y del abuso del derecho, reconocidas por el constituyente de 1991. El fundamento constitucional del principio de la buena fe se encuentra en el artículo 83 de la Constitución Política que reza:

“Las actuaciones de los particulares deberán ceñirse a los postulados de la buena fe, la cual se presumirá en todas las gestiones que aquellos adelanten ante éstas.”

Para (Valencia Zea \& Ortiz Monsalve, 2006): 
"La buena fe indica que cada cual debe celebrar sus negocios, cumplir sus obligaciones y, en general, ejercer sus derechos, mediante el empleo de una "conducta de fidelidad, o sea, por medio de la lealtad y sinceridad que imperan en una comunidad de hombres dotados de criterio honesto y razonable”. En cuanto a las modalidades que adopta la buena fe, precisan:

La buena fe se puede abordar desde dos perspectivas: primeramente cada persona debe usar, una conducta sincera, vale decir, ajustada a las exigencias de decoro social con quien establece una relación jurídica que se denomina buena fe activa; en segundo lugar, cada persona tiene derecho a esperar de la otra esa misma lealtad o fidelidad que toma el nombre de buena fe pasiva.

La Sala de Casación Civil de la Corte Suprema de Justicia ha hecho énfasis en la importancia de la buena fe, denominándolo como principio vertebral de la convivencia social, como de cualquier sistema jurídico, en general, lo constituye la buena fe, con sujeción al cual deben actuar las personas — sin distingo alguno — en el ámbito de las relaciones jurídicas e interpersonales en las que participan, "bien a través del cumplimiento de deberes de índole positiva que se traducen en una determinada actuación, bien mediante la observancia de una conducta de carácter negativo (típica abstención), entre otras formas de manifestación”, y asegura que dicho postulado presupone "que se actúe con honradez, probidad, honorabilidad, transparencia, diligencia, responsabilidad y sin dobleces”.

Sobre el alcance de esta disposición, la Corte Constitucional ha considerado que la buena fe ya cuenta con la importancia para transformarse en un postulado constitucional, su aplicación y proyección ha adquirido nuevas implicaciones, en cuanto a su función integradora del ordenamiento y reguladora de las relaciones entre los particulares y entre estos y el Estado. En nuestro ordenamiento jurídico, el principio de la buena fe tiene expresa consagración en el artículo 83 de la Carta Política, acorde con el cual, "Las actuaciones de los 
particulares y de las autoridades públicas deberán ceñirse a los postulados de la buena fe, la cual se presumirá en todas las gestiones que aquellos adelanten ante éstas".

En materia de derecho privado, este principio se erige como uno de sus pilares y halla su más destacada consagración en el art. 1603 del Código Civil, por cuya virtud "Los contratos deben ejecutarse de buena fe, y por consiguiente obligan no sólo a lo que en ellos se expresa, sino a todas las cosas que emanan precisamente de la naturaleza de la obligación, o que por la ley pertenecen a ella", y en el art. 871 del Código de Comercio, cuando expresa: “Los contratos deberán celebrarse y ejecutarse de buena fe y, en consecuencia, obligarán no sólo a lo pactado expresamente en ellos, sino a todo lo que corresponda a la naturaleza de los mismos, según la ley, la costumbre o la equidad natural”.

Teniendo en cuenta las múltiples disposiciones del Código Civil que aluden al principio de la buena fe, vale la pena traer a colación la clasificación presentada por el autor Arturo Solarte Rodríguez en su artículo "La buena fe contractual y los deberes secundarios de conducta":

Señala un importante sector de la doctrina, que los artículos de los códigos civiles en los que se hace alusión a la buena fe, se pueden clasificar en tres grupos claramente diferenciados, a saber: a) En un primer grupo de textos la buena fe es considerada como la convicción que tiene una persona de que su comportamiento es regular y permitido, aunque en realidad el mismo es irregular y antijurídico.

Un ejemplo de este grupo de normas es el que hace referencia al matrimonio nulo contraído de buena fe, cuando alguno de los contrayentes ha ignorado la existencia del vicio que ocasiona su invalidez y ha expresado su consentimiento con la convicción de la plena validez del acto. La consecuencia que se presenta en estos eventos es que el sujeto es exonerado de sanción o, por lo menos, la que se le impone es atenuada frente a la que 
ordinariamente le correspondería. b) En un segundo grupo la buena fe se asocia con la confianza en la apariencia jurídica.

El sujeto de derecho actúa con la convicción de que su contraparte en una determinada relación jurídica es el titular de un derecho que él aspira a incorporar en su patrimonio, pero en realidad tal apariencia no tiene correspondencia con un derecho subjetivo radicado en el patrimonio de aquél.

Es el caso, por ejemplo, del papel que la buena fe desempeña en la adquisición de cosas muebles por la compra que de ellas se realiza en establecimientos comerciales, cuando el vendedor no es el verdadero propietario de las mismas, caso en el cual, en algunas legislaciones, el derecho protege al adquirente, al impedir que en tal evento sea factible entablar la acción reivindicatoria.

En estos supuestos se ampara la confianza del sujeto de derecho en la apariencia jurídica y la buena fe sirve de presupuesto para la adquisición o para el ejercicio de un derecho subjetivo.

c) En el tercer grupo de disposiciones que aluden a la buena fe, ésta "significa fundamentalmente rectitud y honradez en el trato y supone un criterio o manera de proceder a la cual las partes deben atenerse en el desenvolvimiento de las relaciones jurídicas y en la celebración, interpretación y ejecución de los negocios jurídicos”.21 Estas disposiciones, entre otros efectos, contribuyen a integrar el contenido contractual, con fundamento en que la confianza que debe presidir las relaciones jurídicas le da legitimidad a las expectativas que cada parte se forma respecto del comportamiento de su contraparte durante la vida de una particular relación contractual (2004: 285-286). El mismo autor precisa que el concepto de buena fe no hace referencia a una "percepción íntima que deba ser desentrañada de la conciencia de cada sujeto, sino que, por el contrario, la buena fe es susceptible de ser 
objetivada, de tal manera que el modelo de conducta ideal corresponda a unos parámetros socialmente aceptados" (286).

En cuanto a la culpa precontractual, el principio se aplica cuando, estando avanzada la negociación, una parte se retira, habiendo la otra erogado gastos confiando en la buena fe de aquella (se deben indemnizar los perjuicios). Con relación a la Teoría de la Apariencia en materia de buena fe subjetiva (creencia) es de aplicación cuando el tercer adquirente ignora de buena fe los defectos de su derecho aparente. Se citan casos de cónyuges de buena fe de un matrimonio nulo a anulado, o cuando uno solo de ellos lo es y en diversos efectos en cada supuesto.

\subsection{La buena fe en sentido subjetivo y objetivoSoto Coaguila señala que en sentido} subjetivo la buena fe se refiere a la "intención con que obran las personas o la creencia con que lo hacen, por lo cual se le llama buena fe creencia", y que en sentido objetivo, la buena fe actúa "como regla de conducta, es un estándar jurídico que orienta la actuación ideal del sujeto, lo que determina que se le denomine buena fe-lealtad" (2003: 559). Igualmente, expone que el rol fundamental de la buena fe subjetiva es otorgar derechos, mientras que el de la buena fe objetiva es imponer deberes.

$\mathrm{Al}$ respecto, Solarte Rodríguez destaca que en relación con la buena fe subjetiva se ha distinguido una concepción psicológica entendida como "creencia o ignorancia del sujeto", y la concepción ética de la misma, según la cual "la ignorancia o el error del sujeto sólo serán atendibles en la medida en que su comportamiento no sea culpable" (2004: 287). Es decir que con una diligencia normal no hubiera podido superar su apreciación errada de la realidad. Y en cuanto a la buena fe objetiva, precisa que esta corresponde, por una parte, "al concepto técnico-jurídico referido a la conducta o al comportamiento que se considera como el parámetro que debe ser observado en las relaciones que los particulares establecen"; y por 
otra parte, "es el contenido de un deber de conducta que se concreta en el deber de comportarse con corrección y lealtad en el tráfico jurídico" (288).

Partiendo de las definiciones de la doctrina especializada sobre el tema, Manuel de la Puente y Lavalle presenta una recopilación de las notas que caracterizan la buena fe subjetiva y objetiva: $[\ldots]$ la buena fe subjetiva tiene las siguientes características: a) se trata de una creencia personal del sujeto respecto de que su actuación es conforme a Derecho, o sea que tiene contenido ético. b) Esta creencia, pese a ser subjetiva, no es candorosa, sino razonada, en el sentido que el sujeto ha apreciado los elementos de juicio que estaban a su disposición. c) La apreciación del sujeto es fruto de su diligencia, esto es, que ha hecho una búsqueda razonable de los elementos de juicio. d) En este proceso de formación de la creencia no ha actuado con dolo o culpa. e) La creencia del sujeto puede recaer tanto en su propia situación como en la de la persona con la cual se relaciona. f) La creencia, así formada, determina la conducta del sujeto, en el sentido que hay una absoluta correspondencia entre su creer y su actuar. g) El derecho da un tratamiento favorable a la conducta del sujeto por razón de su creencia.

Tratándose de la buena fe objetiva, las mismas fuentes doctrinales le otorgan las siguientes características: a) Se trata de un deber de conducta impuesto al sujeto, con un contenido eminentemente ético. b) Este deber de conducta importa que no se perjudiquen los intereses ajenos fuera de los límites impuestos por la tutela legítima de los intereses propios. c) Para apreciar la conducta se prescinde del punto de vista subjetivo de las partes para referirse a un criterio objetivo.

d) Esta objetividad no excluye, sin embargo, que deje de tomarse en consideración un elemento subjetivo, como es el dolo o culpa del sujeto. Quien actúa con dolo o culpa no puede escudarse en la buena fe objetiva. e) El criterio objetivo consiste en la comparación de la conducta del sujeto con un standard jurídico, o sea un prototipo de conducta social media. f) 
El standard jurídico aplicable debe buscarse teniendo en cuenta el contexto social en el que actúa el sujeto (2000: 276-277). Aunque la precedente clasificación es muy importante, en este trabajo tiene mayor relevancia el análisis de la buena fe desde la perspectiva contractual y sus manifestaciones concretas en las categorías conocidas como prohibición de actuar contra los actos propios, principio de confianza legítima y abuso de la posición dominante, por lo que interesa en mayor medida detenerse solo en las repercusiones jurídicas de la buena fe objetiva, definida por Marta Lucía Neme Villareal como "principio jurídico que introduce en el contenido de las obligaciones deberes coherentes con un modelo de comportamiento objetivo, el del bonus vir, que se expresa a través de reglas de honestidad y corrección propias de dicho modelo" (2003: 49). Por ello, no es menester profundizar en las implicaciones jurídicas de la buena fe subjetiva que, en términos generales, se concretan en el otorgamiento de derechos, ni de aquellas que pueden derivarse de la falta de claridad en la distinción de los conceptos de buena fe subjetiva y objetiva.

La buena fe contractual La buena fe objetiva, entendida como norma de conducta, como el deber de comportarse con rectitud, honradez y lealtad, impone a las partes una directriz de cómo deben proceder en el desarrollo de las relaciones jurídicas que surjan con ocasión de la celebración de negocios jurídicos, en las fases precontractual, de ejecución del contrato y aun postcontractual. El profesor Solarte Rodríguez afirma que esta categoría de la buena fe tiene una muy importante función en el ordenamiento jurídico, por cuanto en la medida que la norma escrita no tiene la virtud de contemplar la totalidad de las situaciones que se pueden presentar entre los contratantes, el principio general de la buena fe "permite identificar otras prohibiciones y otras obligaciones además de aquellas previstas por la ley; como suele decirse «cierra» el sistema legislativo, es decir, ofrece criterios para colmar aquellas lagunas que se puedan manifestar en múltiples y variadas situaciones de la vida económica y social” (2004:288-289). 
Y en cuanto a la aplicación de este principio en las diferentes fases del contrato, señala: Según indica la doctrina uniformemente, la buena fe contractual tiene aplicación no sólo en la ejecución del acto jurídico, sino también en el desarrollo de las negociaciones y en la formación del contrato, fundamentalmente, a través del denominado deber de información.

Asimismo, en esta etapa se manifiesta en el deber de no interrumpir intempestivamente y sin causa los tratos preliminares al contrato, so pena de indemnizar los perjuicios que se puedan causar, particularmente por el denominado "daño in contrahendo". Por otra parte, y ya en el terreno de la ejecución de un contrato debidamente perfeccionado, la buena fe contractual hace surgir un catálogo de deberes de conducta que, de acuerdo con la naturaleza de la respectiva relación, amplía los deberes contractualmente asumidos por cada parte para con ello realizar el interés contractual de la otra parte. Finalmente, la buena fe sirve como limitación al ejercicio de los derechos subjetivos proscribiendo el abuso o la desviación en su ejercicio, e impulsa a las partes a ser coherentes en su comportamiento, evitando contradecir sus propios actos, entre otras conductas.

El principio de la autonomía de la voluntad privada ha sido definido como el poder de las personas, reconocido por el ordenamiento positivo para disponer con efecto vinculante de los intereses y derechos de los que son titulares y por ende crear derechos y obligaciones, siempre que respete el orden público y las buenas costumbres, tal y como figura en la Sentencia C- 1194 de 2008.

\subsection{Marco Conceptual}

BUENA FE es un principio general del Derecho, consistente en el estado mental de honradez, de convicción en cuanto a la verdad o exactitud de un asunto, hecho u opinión, título de propiedad, o la rectitud de una conducta. Exige una conducta recta u honesta en relación con las partes interesadas en un acto, contrato o proceso. 
CONTRATISTA es la persona o empresa que es contratada por otra organización o particular para la construcción de un edificio, carretera, instalación o algún trabajo especial.

CONTRATO DE SEGURO El contrato de seguro es el acuerdo por el cual una de las partes, el asegurador, se obliga a resarcir de un daño o a pagar una suma de dinero a la otra parte, tomador, al verificarse la eventualidad prevista en el contrato, a cambio del pago de un precio, denominado prima, por el tomador. El contrato de seguro puede tener por objeto toda clase de riesgos si existe interés asegurable, salvo prohibición expresa de la ley.

GARANTÍA es un negocio jurídico mediante el cual se pretende dotar de una mayor seguridad al cumplimiento de una obligación o pago de una deuda, su subsistencia está ligada a la existencia de la principal.

CLASES DE GARANTÍAS Las garantías que los oferentes o contratistas pueden otorgar para asegurar el cumplimiento de sus obligaciones son:

1. Contrato de seguro contenido en una póliza.

2. Patrimonio autónomo.

3. Garantía Bancaria.

GARANTÍA DEL OFERENTE PLURAL: Se da cuando la oferta es presentada por un proponente plural, como Unión Temporal, Consorcio o promesa de sociedad futura, en estos casos la garantía debe ser otorgada por todos sus integrantes.

PRESUNCIONES: Se dice presumirse el hecho que se deduce de ciertos antecedentes o circunstancias conocidas. (C.C. ARTICULO 66).

PRESUNCIÓN DE BUENA FE: "La buena fe se presume, excepto en los casos en que la ley establece la presunción contraria. En todos los otros, la mala fe deberá probarse. (C.C. ARTICULO 769).

PRESUNCIÓN LEGAL: Se genera cuando los antecedentes o circunstancias que dan motivo a la presunción son determinados por la ley, en estos casos es permitido probar la no 
existencia del hecho que legalmente se presume, aunque sean ciertos los antecedentes o circunstancias de que lo infiere la ley, a menos que la ley misma rechace expresamente esta prueba, supuestos los antecedentes o circunstancias.

PRESUNCIÓN DE DERECHO: Se genera cuando la ley refiere que la presunción no admite prueba contraria una vez se configuran los antecedentes o circunstancias de la presunción.

PRESUNCIÓN DE DOLO. El dolo no se presume sino en los casos especialmente previsto por la ley. En los demás debe probarse. (C.C. ARTíCULO 1516).

PRINCIPIO DE BUENA FE: Los contratos deberán celebrarse y ejecutarse de buena fe y, en consecuencia, obligarán no sólo a lo pactado expresamente en ellos, sino a todo lo que corresponda a la naturaleza de los mismos, según la ley, la costumbre o la equidad natural. (Código de Comercio. Artículo 871).

\section{RIESGOS QUE SE DEBEN CUBRIR EN LAS GARANTÍAS EN LA}

CONTRATACIÓN: Son los derivados de (i) la presentación de las ofertas; (ii) los contratos y su liquidación; y (iii) los riesgos a los que se encuentran expuestas los Contratantes, derivados de la responsabilidad extracontractual que pueda surgir por las actuaciones, hechos u omisiones de sus contratistas y subcontratistas.

\subsection{Estado del Arte}

Respecto del tema de la buena fe, encontramos que existen varios autores que se han pronunciado y han analizado dicho principio, entre ellos se pueden resaltar el tratadista Arturo Solarte Rodríguez y el Dr. Edgar Augusto Arana Montoya, cuyas obras abordan el tema de la buena fe desde diversas perspectivas.

En efecto, en primer lugar al Dr. Oscar Arturo Solarte Rodríguez quien en el documento titulado "la buena fe contractual y los deberes secundarios de conducta" trata el tema concreto de los deberes de conducta que le asiste a las partes dentro de un contrato y su relación con el 
principio fundamental de la buena fe, documento este importante como antecedente para la presente investigación, en la medida que se puede relacionar con la actividad que se le puede exigir constitucionalmente a un contratista y los límites que en materia de garantías se pueden extraer del derecho fundamental de la buena fe.

También se cuenta con varios documentos que han tratado el tema, tales como el titulado

“Tensión entre autonomía y la buena fe en la contratación privada contemporánea” de Adriana Largo Taborda, Edición: 2012.

Igualmente, existen múltiples jurisprudencias de la Corte Constitucional y el Consejo de Estado que tratan el tema de la buena fe, tales como:

- CONSEJO DE ESTADO. SALA DE LO CONTENCIOSO ADMINISTRATIVO. SECCION TERCERA. SUBSECCION C. Consejero ponente: JAIME ORLANDO SANTOFIMIO GAMBOA. Bogotá D.C veintidós (22) de junio de dos mil once (2011). Radicación número: 85001-23-31-003-1998-00070-01(18836). Actor: TOPCO S. A. Demandado: INSTITUTO NACIONAL DE VIAS-INVIAS. Referencia: ACCION CONTRACTUAL - RECURSO DE APELACION

- Referencia: expediente T-2.704.030. Acción de tutela instaurada por Oscar Alfredo Fajardo Ortega contra la Universidad Distrital Francisco José de Caldas. Magistrado Ponente: HUMBERTO ANTONIO SIERRA PORTO. Bogotá D.C. veintiocho (28) de octubre de dos mil diez (2010).

- Consejo de Estado Sección Tercera. Sentencia de septiembre 11 de 1989. Exp. 5334 Magistrado Ponente: Gustavo De Greiff Restrepo

- Consejo de Estado Sección Tercera. Sentencia de marzo 14 de 2013. Radicado N 19960357701 Magistrado Ponente: Alberto Zambrano Barrera

- Consejo de Estado Sección Tercera. Sentencia de septiembre 13 de 1991 Exp. 5127 Magistrado Ponente: Carlos Alberto Betancourt 
- Consejo de Estado Sección Tercera. Sentencia de mayo 6 de 1992 Exp. 5931 Magistrado Ponente: Carlos Alberto Betancourt

- Consejo de Estado Sección Tercera. Sentencia de octubre 1 de 1992 Exp. 6631

Magistrado Ponente: Carlos Alberto Betancourt

- Consejo de Estado Sección Tercera. Sentencia de septiembre 20 de 1995 Exp. 7757

Magistrado Ponente: Juan de Dios Montes Hernández

- Consejo de Estado Sección Tercera. Sentencia de septiembre 13 de 1999 Exp. 10264

Magistrado Ponente: Ricardo Hoyos Duque

- Consejo de Estado Sección Tercera. Sentencia de agosto 24 de 2000 Exp. 11318.

Magistrado Ponente: Jesús María Carillo Ballesteros

- Consejo de Estado Sección Tercera. Sentencia de octubre 20 de 2005 Exp. 14.579

Magistrado Ponente: Germán Rodríguez Villamizar

- Consejo de Estado Sección Tercera. Sentencia de junio 18 de 2008 Exp. 29.290.

Magistrado Ponente: Mauricio Fajardo Gómez

- Consejo de Estado Sección Tercera. Sentencia de julio 30 de 2008 Exp. 21574

Magistrado Ponente: Enrique Gil Botero

- Consejo de Estado Sección Tercera. Sentencia de septiembre 29 de 2009. Radicado $N^{\circ}$ 2003- 0442-01 Magistrada Ponente: Susana Valencia Buitrago

- Consejo de Estado. Sentencia de abril 22 de 2009 Exp. 14.667 Magistrada Ponente: Myriam Guerrero de Escobar

- Consejo de Estado Sección Tercera. Sentencia de marzo 17 de 2010. Radicado Nº 19920117- 01 Magistrado Ponente: Ruth Stella Correa Palacio

- Consejo de Estado Sección Tercera. Sentencia de junio 23 de 2010. Radicado N 1994 00225- 01 Magistrado Ponente: Enrique Gil Botero 
- Consejo de Estado Sección Primera. Sentencia de junio 16 de 2011. Radicado N²00205455 Magistrado Ponente: Marco Antonio Velilla Moreno

- Consejo de Estado Sección Tercera. Sentencia de marzo 21 de 2012. Exp. 39477 Magistrado Ponente: Jaime Orlando Santofimio

- Consejo de Estado. Sentencia de junio 6 de 2013. Radicado N²009-00245-01

Magistrada Ponente: María Elizabeth García

Frente al tema de las garantías, en material legal se encuentra regulado en el Código Civil Colombiano, sin embargo para el tema específico de garantías exigibles en contratos privados, no existe una normatividad expresa, como en los contratos administrativos, con la Ley 80 de 1993.

Para la presente investigación se partirá del antecedente regulado en la Ley 80 de 1993, "Por la cual se expide el Estatuto General de Contratación de la Administración Pública", que a pesar de ser usado para contratos con la administración pública, las aseguradoras la tienen en cuenta en el momento de expedir la famosa Póliza de cumplimiento; ya que es una de las pólizas más utilizadas para cumplir con las exigencias de la mayoría de los contratos entre particulares, pues ampara a los contratantes desde la etapa precontractual hasta después de la entrega de los trabajos.

Finalmente, en cuanto a la falta de normatividad en garantías de contratos privados, con esta investigación se pretende poner de presente que algunas de estas garantías son excesivas y que eso desconoce, en buena parte, la noción de la buena fe contractual.

\subsection{Enfoque Metodológico}

En esta investigación, el estudio de caso será la herramienta metodológica que acompañe la construcción de este trabajo, a pesar de que algunos autores (Stoeker, 1991; Venkatraman \& Grant 1986, Rouse \& Daellenbach, 1999; Bower \& Wiersema, 1999) lo cuestionen, por considerar que su prestigio es bajo, que no suele considerarse como una buena estrategia para 
realizar investigación científica, y que el método de estudio de caso presenta problemas de fiabilidad y validez, debido a lo cual en la investigación empírica se utilizan básicamente métodos cuantitativos.

No obstante, el método de estudio de caso es una herramienta valiosa de investigación, y su mayor fortaleza radica en que a través del mismo se mide y registra la conducta de las personas involucradas en el fenómeno estudiado, mientras que los métodos cuantitativos sólo se centran en información verbal obtenida a través de encuestas por cuestionarios (Yin, 1989). Además, en el método de estudio de caso los datos pueden ser obtenidos desde una variedad de fuentes, tanto cualitativas como cuantitativas; esto es, documentos, registros de archivos, entrevistas directas, observación directa, observación de los participantes e instalaciones u objetos físicos (Chetty, 1996).

Por consiguiente, para acreditar el abuso del derecho y el desconocimiento de la buena fe en algunas relaciones contractuales de la Empresa Colombiana de Petróleos S.A., se estudiaron en detalle algunos contratos en los que es parte aquella empresa, con la aclaración de que previamente se discurrió sobre la naturaleza y el contenido del principio de la buena fe y la teoría del abuso del derecho, para analizar a partir de estas dos últimas cuestiones el comportamiento de Ecopetrol.

\section{El principio de la buena fe en Colombia}

La buena fe (del latín, bona fides) es un principio general del Derecho, que consiste en el estado mental de honradez, de convicción en cuanto a la verdad o exactitud de un asunto, hecho u opinión, título de propiedad, o la rectitud de una conducta. Este exige una conducta recta u honesta en relación con las partes interesadas en un acto, contrato o proceso. 
Para iniciar se hace una referencia y distinción entre los diferentes conceptos que derivan en la buena fe como principio. Es así como el principio se define como un axioma que plasma una determinada valoración de justicia de una sociedad, sobre la que se construyen las instituciones del Derecho y que en un momento histórico determinado informa del contenido de las normas jurídicas de un Estado (Machicado, 2001). Es el fundamento, es la base de una garantía.

Para efectos del Derecho procesal, Eduardo Couture lo definía como la "calidad jurídica de la conducta legalmente exigida de actuar en el proceso con probidad, con el sincero convencimiento de hallarse asistido de razón". En este sentido, este principio busca impedir las actuaciones abusivas de las partes, que tengan por finalidad alargar un juicio.

La buena fe es aplicada en diversas ramas del Derecho. La buena fe está prevista en el Código de Comercio, en el Código Civil y en la Ley de Sociedades, en varias oportunidades. Por ejemplo en el Derecho civil, a efectos de la prescripción adquisitiva de un bien, a quien lo ha poseído de "buena fe" se le exige un menor tiempo que a aquel que lo ha hecho de "mala fe". En la celebración del contrato obliga a las partes a expresar sus ideas con claridad. También, la buena fe en la interpretación del acto que implica la confianza ante una declaración de voluntad de que sus efectos serán los previsibles, por normales, en el caso dado. Los jueces no deben admitir la reserva mental, ni aceptar como válida una diferente acepción de los vocablos que alguna de las partes diga haber querido significar para salvar su responsabilidad.

Buena fe en la ejecución del acto representa que las partes se obligan al cumplimiento de las obligaciones de la forma que, en cada caso, es dable entre personas de conducta recta. En derecho mercantil, adquiere connotaciones particulares debido a la especificidad de esta material y a los institutos que le son propios. Las operaciones masivas, la búsqueda del lucro, el carácter de comerciante hacen de la buena fe la base de la equidad en el mercado y de las 
correctas relaciones de los comerciales entre sí y con el consumidor. Con la buena fe se puede determinar, valorar, interpretar y hasta calificar las conductas de las partes al perseguir sus ventajas.

La buena fe se presume, en cambio la mala fe, debe probarse para descalificar una conducta. Es deber de los magistrados al crear un derecho en el caso concreto guiarse por este principio en la búsqueda de una solución satisfactoria y ecuánime. El principio de la buena fe tiene mucha importancia en los contratos de trabajo en atención a la relación personal prolongada en el tiempo, la cual exige una confianza recíproca y un mutuo respeto en el cumplimiento de las obligaciones, más allá de cualquier otro conducta, denominada también buena fe lealtad de las partes. Esto se traduce en que el trabajador produzca sin restringir su esfuerzo rinda, en la acepción aludida anteriormente y el empleador corresponda cumpliendo acabada y oportunamente todas sus obligaciones. Dentro de estas pautas el juzgador actuará con la elasticidad que admita el caso concreto.

\subsection{Historia.}

En general, en las diversas ramas del Derecho reciben un tratamiento diferenciado las personas que actuaron de buena o de mala fe. La evolución del principio de la buena fe en el Derecho Romano, se puede evidenciar en dos etapas cada una con diferentes significados: la etapa clásica y la postclásica.

En la primera etapa, la etapa clásica, la buena fe principalmente se predica de las acciones, diferenciándolas de las de derecho estricto, de forma que la buena fe es básicamente una cualidad que tienen determinados juicios y que comporta un determinado modo o método de juicio (Arias, 1986). En la segunda etapa, el principio de buena fe se entiende en este periodo como un principio rector de la conducta. Son dos concepciones diferentes del mismo principio de buena fe (una lo entiende como método de juicio, la otra como regla de 
conducta), no necesariamente opuestas o contradictorias (Arias, 1986), si bien cada una tiene su propio contenido y sus peculiares consecuencias.

La fides es un principio fundamental del Derecho Romano que manifiesta el deber de toda persona de respetar y cumplir su palabra (Castro, 1983). Se entiende también como un principio vigente en todos los pueblos, es decir de ius gentium y no como un principio característico de los romanos.

Ius Gentium o jus Gentium, el derecho de gentes, comprende las instituciones del Derecho Romano de las que pueden participar los extranjertos (peregrini) los mismos realizaban trueques, pactos, tratos ,acuerdos, negocios comerciales y demás con Roma y cada uno de sus ciudadanos.

En sentido general el ius Gentium o de los pueblos, puede observarse entre todos los pueblos sin discriminación de nacionalidades, cabe destacar que el derecho de gentes se acerca al derecho natural, pero estos no deben confundirse ya que por ejemplo la esclavitud que era aceptada por todos los pueblos de la antigüedad como derecho de gentes, pero por los juristas clásicos era reconocida como contrario al derecho natural.

En la teoría jurídica, la ley que la razón natural establece para todos los hombres, a diferencia de jus civile, o el derecho civil propio de un estado o pueblo.

Abogados y magistrados romanos idearon originalmente jus Gentium como un sistema de equidad de la aplicación a los casos que cualquier estado de derecho común a todas las naciones debe ser fundamentalmente valida y justa. Con el tiempo el termino se convirtió en sinónimo de equidad.

Ius civile, anteriormente se presentó como un conjunto de reglas que regularon las relaciones entre los ciudadanos romanos . Este derecho natural nunca fue legislado, pero se constituía por un conjunto de principios que la misma naturaleza inspira asiduamente en el 
hombre sobre el bien y el mal. De la misma manera, es la causa de las obligaciones derivadas de los contratos consensuales.

Diferente de ella es la bona fides que surge en la fórmula de algunas acciones. Así, las acciones de buena fe que se conocen en el Edicto del pretor eran éstas: la acción del antiguo negocio de fiducia, que parece haber sido la matriz de las demás acciones de buena fe, las acciones de los cuatro contratos consensuales (mandato, sociedad, compraventa y arrendamiento), la del depósito, la acción de gestión de negocio ajeno y las acciones de tutela (para exigir cuentas al tutor) y la de dote (actio rei uxoriae para exigir la restitución de la misma).

De esta forma y retomando lo planteado anteriormente, esta bona fides a que se refieren las fórmulas de las acciones contractuales, no es la causa de la que deriva la obligación contractual, la cual es efecto del mero consentimiento informal, es decir de la sola fides. Por ello, en el Derecho Clásico, la bona fides califica las acciones y no las obligaciones, ya que las acciones contractuales son acciones de buena fe (Cuadrado, 2003).

Es así, como se pueden presentar al fin de esta evolución que la buena fe como razón de juicio contiene los siguientes criterios derivados de la fórmula o del contrato mismo, desde el Derecho Romano. Son ellos:

a) La diligencia en el cumplimiento. En las acciones de buena fe no se trata solamente de verificar si el deudor cumplió o no la palabra empeñada, pues lo que se procura es que el juez verifique si la cumplió como lo haría un hombre bueno, es decir si la cumplió bien. Por lo tanto se constituye en una medida más exigente del cumplimiento de las obligaciones, que la que se aplica a un deudor de una obligación sancionada por una acción de derecho estricto quien, por ejemplo, saldría absuelto si no puede entregar la cosa prometida que se perdió sin dolo suyo, en tanto que el deudor de una obligación contractual sancionada 
por una acción de buena fe quedaría condenado en el misma caso por no haber obrado con la diligencia debida (Díez, 1996).

La razón que existe para esta mayor exigencia no es en si el castigo del deudor, si no la naturaleza misma del contrato como obligación recíproca, que supone que ambas partes confiaron una en la otra, y que cada una se obligó a causa de la confianza que depositó en que la otra cumpliría su palabra. Por tanto, las dos partes son a la vez acreedoras y deudoras, de modo que al exigir la acción de buena fe más responsabilidad al deudor, a ambas se la exige y a ambas beneficia.

Otro hecho concreto, es la mayor exigencia propia de las acciones de buena fe que se da en el acto de que la condena ha de resarcir el interés del actor, es decir, que el juez para determinar el monto de la condena considera, además del valor de la prestación incumplida, el valor de los daños y perjuicios que sufre el acreedor por el incumplimiento, de modo que el monto de la condena se refiera al interés que tenía el acreedor en que la obligación se cumpliera (id quod interest) (Díez, 1996).

b) La sanción del dolo. Se inicia entendiendo al dolo como conocimiento y voluntad de realizar el tipo objetivo de un delito (dolus naturalis). Son por tanto dos los elementos que integran el dolo, el elemento intelectual o cognoscitivo y el elemento volitivo. Para el caso de la sanción, significa que las partes deben prescindir del dolo o engaño entre ellas, tanto en la celebración de determinado contrato, como en su ejecución y cumplimiento (Gómez, 1994). Mientras que en las acciones de derecho estricto, el juez investiga si hubo dolo únicamente cuando alguna de las partes lo incluye en la fórmula, en las acciones de buena fe se entiende que el juez debe investigar y sancionar el dolo que hubiera habido entre las partes sin necesidad de que alguna de las partes lo invoque. Por eso llegó a decirse que la excepción de dolo era inherente a las acciones de buena fe (Gómez, 1994). 
c) La interpretación de lo realmente querido por las partes. Los anteriores criterios enunciados: mayor exigencia en el cumplimiento y ausencia de dolo, se complementan con otros extraídos de la propia naturaleza consensual y bilateral de las relaciones a las que se refiere (Wieacker, 1982). Es decir, en los contratos de derecho estricto (stricti iuris) las partes deben atenerse exclusivamente a lo acordado y el acreedor sólo podrá exigir del deudor lo que éste "estrictamente" prometió, sin que el juez puede añadir ni quitar nada, aunque ello choque a veces con los principios elementales de la equidad. Así, en el contrato de mutuo (de derecho estricto), el mutuante (acreedor) sólo podrá pretender del mutuario (deudor) estrictamente la devolución de la cantidad prestada, pero no podrá exigir el pago de intereses o una congruente indemnización en caso de mora, si no se hubiese pactado expresamente. Por el contrario, en los contratos de buena fe el acreedor no sólo podrá exigir lo prometido, sino también todo aquello que sea exigible "según la buena fe", con arreglo a las circunstancias del caso concreto. Son por ejemplo la sociedad, el comodato, el mandato, etc.

La distinción se desvanece en Derecho justinianeo, donde se prescribe con carácter general que el juez debe siempre juzgar ex bono et aequo, esto es, teniendo en cuenta las circunstancias concretas según la buena fe y la equidad. Que la buena fe sigue siendo un ingrediente fundamental en el sistema contractual romano lo demuestra el contenido del artículo $1258,2^{\circ}$ del Código civil.

d) Criterios derivados de la bilateralidad de la obligación. Se refiere al criterio de juicio para determinar la condena propio de las acciones de buena fe, cual es es el de compensar las deudas recíprocas provenientes del mismo contrato (ex pari causa) (Gómez, 1994).

Para concluir, en el Derecho Romano clásico, la buena fe no es una regla de conducta, sino un método de decisión judicial que la da al juez mayor libertad para determinar la condena, haciendo una interpretación amplia (Carcaterra, 1952) del contenido de la fórmula y 
de lo realmente convenido por las partes. Tal interpretación hace que el juez al juzgar tenga en cuenta estos ocho criterios de juicio: 1) la consideración de la culpa para definir el incumplimiento de las obligaciones contractuales 2) el monto de la condena ha de subsanar el interés del actor en que la obligación se hubiera cumplido; 3) la represión del dolo, entendido como engaño provocado o aprovechamiento del error o ignorancia espontánea de la otra parte; 4) la interpretación del contrato con el criterio de comprender lo realmente convenido por las partes con preferencia a la literalidad de las palabras; 5) la consideración de todos los pactos que hubieran hecho las partes aunque no los invocaran en la fórmula; 6) el tener como convenidos los elementos naturales del negocio; 7) la compensación de las deudas recíprocas derivadas del mismo contrato y 8) la consideración de la equidad o el equilibrio entre las prestaciones (Hernández, 1979).

De ahí, el fundamento o causa de este método de juzgar es la propia naturaleza bilateral y consensual de los contratos. La herencia del derecho Romano permitió el desarrollo de la buena fe como principio; para proseguir con el esclarecimiento del principio de buena fe aplicado a los contratos internacionales, haré un análisis sintético y breve de cómo se ha entendido este principio en la tradición jurídica común, la del Derecho Romano.

El análisis de este principio en la historia del Derecho Romano debe distinguir dos etapas en las que tiene significados diferentes, la etapa clásica y la postclásica. En la primera la buena fe se predica principalmente de las acciones o juicios, y sirve para distinguir entre las acciones o juicios de buena fe de aquellos otros llamados de derecho estricto, de suerte que la buena fe es fundamentalmente una cualidad que tienen ciertos juicios y que comporta un determinado modo o método de juicio. En la segunda, la buena fe se predica como una cualidad de los contratos o bien se sustantiviza, convirtiéndose en un principio jurídico del cual derivan reglas o prescripciones de carácter imperativo; el principio de buena fe comienza a entenderse en esta etapa posclásica como un principio rector de la conducta. Son dos 
concepciones diferentes del mismo principio de buena fe (una lo entiende como método de juicio, la otra como regla de conducta), no necesariamente opuestas o contradictorias, si bien cada una tiene su propio contenido y sus peculiares consecuencias.

La jurisprudencia la relaciona con la evolución que tuvo el propio concepto de Derecho. El concepto del Ius o de la Jurisprudentia como un arte o ciencia elaborado primordialmente por los juristas fue sustituido, claramente desde el siglo IV, por el concepto del Derecho como un ordenamiento imperativo emanado de la potestad imperial. La Buena fe entonces, es uno de los principios imperativos del ordenamiento jurídico, y es por lo mismo fuente de deberes, regla de conducta (Jordano, 1987).

El constituyente colombiano reconociendo la importancia en el ordenamiento colombiano el principio de buena fe resulta un elemento connatural al sistema jurídico, consagrado expresamente por el artículo 83 de la Constitución de 1991. Dicho principio aporta un contenido de naturaleza ética y de rango constitucional a las relaciones de los particulares entre sí, y de éstos con las autoridades públicas. Adicionalmente debe resaltarse que el principio de buena fe fue concebido por el constituyente como un mecanismo para buscar la protección de los derechos, los que tendrán menos amenazas si en las actuaciones que se surtan ante las autoridades, o en la interpretación de las relaciones negociales entre particulares y administración, o en el entendimiento de las relaciones entre particulares se toma la buena fe como un elemento fundacional de las mismas y de ella se derivan contenidos de solidaridad, probidad, honestidad y lealtad.

Por su parte la Corte ha señalado que la buena fe es un principio que de conformidad con el artículo 83 de la Carta Política se presume y conforme con este (i) las actuaciones de los particulares y de las autoridades públicas deben estar gobernadas por el principio de buena fe y; (ii) ella se presume en las actuaciones que los particulares adelanten ante las autoridades públicas, es decir en las relaciones jurídico administrativas, pero dicha presunción solamente 
se desvirtúa con los mecanismos consagrados por el ordenamiento jurídico vigente, luego es simplemente legal y por tanto admite prueba en contrario (Sentencia C-1194/08).

La jurisprudencia constitucional ha definido el principio de buena fe como aquel que exige a los particulares y a las autoridades públicas ajustar sus comportamientos a una conducta honesta, leal y conforme con las actuaciones que podrían esperarse de una “persona correcta (vir bonus)”. Así la buena fe presupone la existencia de relaciones reciprocas con trascendencia jurídica, y se refiere a la "confianza, seguridad y credibilidad que otorga la palabra dada”

La Corte ha señalado que la buena fe es un principio que de conformidad con el artículo 83 de la Carta Política se presume y conforme con este (i) las actuaciones de los particulares y de las autoridades públicas deben estar gobernadas por el principio de buena fe y; (ii) ella se presume en las actuaciones que los particulares adelanten ante las autoridades públicas, es decir en las relaciones jurídico administrativas, pero dicha presunción solamente se desvirtúa con los mecanismos consagrados por el ordenamiento jurídico vigente, luego es simplemente legal y por tanto admite prueba en contrario.

La Corte Constitucional ha considerado que en tanto la buena fe ha pasado de ser un principio general de derecho para transformarse en un postulado constitucional, su aplicación y proyección ha adquirido nuevas implicaciones, en cuanto a su función integradora del ordenamiento y reguladora de las relaciones entre los particulares y entre estos y el Estado, y en tanto postulado constitucional, irradia las relaciones jurídicas entre particulares, y por ello la ley también pueda establecer, en casos específicos, esta presunción en las relaciones que entre ellos se desarrollen.

En esta sentencia se hace un importante análisis del alcance del principio de Buena fe como presunción donde se establece que bajo algunos postulados taxativos, definidos por el 
legislador, el principio objeto de este estudio pasa a ser una presunción que admite prueba en contrario, puesto que es aquí donde se establece una variación en la carga de la prueba puesto que esta recae sobre el comprador incumplido que debe entrar a demostrar que su falta a lo pactado obedeció a motivos que generaron un detrimento en su patrimonio, en otras palabras debe demostrar que no actuó con mala fe al no pagar el precio pactado en el contrato.

En este contexto y debido a su carácter de elemento fundamental del tráfico jurídico, el principio de buena fe es aplicado en un sinnúmero de situaciones entre las que se cuentan las relaciones contractuales, sean éstas entre particulares solamente o entre particulares y la administración. Lo que importa resaltar ahora es que, en el caso de relaciones de tipo contractual, el principio de buena fe se presenta en todas las etapas de la relación, razón por la cual cuando el juez evalúa el desarrollo de un contrato el principio de buena fe debe ser presupuesto integral de dicha evaluación; en este sentido manifestó la Corte Suprema de Justicia (Sentencia C-1194/08):

"De allí que la buena fe no se pueda fragmentar, en orden a circunscribirla tan solo a un segmento o aparte de una fase, por vía de ejemplo: la precontractual - o parte de la precontractual -, ya que es necesario, como corresponde, auscultarla in globo, según se indicó valorando las diversas oportunidad que los interesados tuvieron para actuar con lealtad, corrección (correttezza) y diligencia, según sea el caso."

Para el tema que nos ocupa el contrato debe desde su inicio de su concepción ir blindado con el principio de la buena fe, en todas sus etapas (etapas precontractual, contractual y pos contractual). El principio de la buena fe invita a los particulares a conservar una coherencia en sus actuaciones, respeto por el compromiso adquirido y por la palabra empeñada

\subsection{Concepto de buena fe}

Según lo anterior, el principio de la buena fe es la base de la fuerza obligatoria en el contrato que se observa desde la figura de un principio general del derecho y sus funciones innatas 
además de soporte de las normas secundarias de conducta, propias de las relaciones contractuales.

De acuerdo con su definición y teniendo en cuenta los autores Valencia Zea y Ortiz Monsalve (2006: 212-213), la buena fe señala que cada cual debe celebrar sus negocios, cumplir sus obligaciones y, en términos generales, ejercer sus derechos, por medio del empleo de una "conducta de fidelidad, es decir, mediante la lealtad y sinceridad que imperan en una comunidad de individuos dotados de criterio honesto y razonable". De la misma forma en cuanto a las características que adopta la buena fe, se puede precisar que la buena fe se desarrolla en dos aspectos primordiales: En primera medida cada individuo debe emplear para con cualquier persona con quien constituye una relación jurídica, una conducta sincera que al mismo tiempo se encuentre ajustada a las exigencias que por naturaleza se tienen al pertenecer a la sociedad; en segundo lugar, cada individuo tiene derecho a esperar de la otra persona con quien establece este tipo de relación, esa misma probidad o fidelidad (Ortiz, 2006). De lo anterior se tiene que para el primer asunto se trata de una buena fe activa, y para el segundo, de una buena fe pasiva (confianza).

Paralelamente a lo anterior, Emilio Betti define la buena fe como "una actitud de cooperación encaminada a cumplir de modo positivo la expectativa de la otra parte" (Betti, 1959), cualidad que tiene como características más destacadas la fidelidad, la confianza, el deber, la capacidad de sacrificio y la premura en auxiliar a la otra parte.

Por su parte, la Sala de Casación Civil de la Corte Suprema de Justicia ha especificado que el principio básico de la convivencia social, así como de cualquier sistema jurídico, generalmente lo constituye la buena fe, con sujeción al cual les corresponde actuar a las personas, independientemente de su condición o situación. Añade este ente también, que en el terreno de las relaciones jurídicas e interpersonales en las que participan los individuos, bien sea por medio del acatamiento de deberes de índole positiva, traducidos en una actuación 
determinada, o también por medio de observar una conducta de carácter negativo (típica inhibición), entre otras formas de expresión. Este postulado indica y reconoce que se debe actuar con honradez, probidad, honorabilidad, transparencia, diligencia, responsabilidad y sin dobleces (CSJ, 2007).

De otra parte los artículos de los códigos civiles en el derecho comparado, en los que se hace mención a la buena fe, la clasifican en tres grupos claramente diferenciados, a saber:

a) Un grupo considera la buena fe como el convencimiento que tiene un individuo de que su comportamiento es regular y permitido, no obstante realmente el mismo es irregular y antijurídico (Solarte, 2009). Un claro ejemplo de lo anterior es el referente al matrimonio nulo que se contrae de buena fe, cuando cualquiera de los contrayentes ha desconocido la existencia del vicio que produce su invalidez y ha señalado su consentimiento con la certeza de la plena validez del acto. El resultado presentado en estos hechos es que el sujeto es exento de sanción o, por lo menos, la que se le impone es mitigada frente a la que ordinariamente le correspondería.

b) De otro lado, un segundo grupo asocia la buena fe con la confianza en la apariencia jurídica. Esto quiere decir que el sujeto de derecho actúa con el convencimiento de que su contraparte en una relación jurídica determinada, es el titular de un derecho que él desea agregar en su patrimonio, pero realmente este aspecto no tiene correspondencia con un derecho subjetivo radicado en el patrimonio de aquél individuo (Ponce de León, 2010). Este caso se puede ejemplificar en el papel que juega la buena fe en la adquisición de cosas muebles compradas en establecimientos comerciales, cuando el vendedor no es el propietario real de las mismas, caso en el cual, en varias legislaciones, el derecho resguarda al adquiriente, impidiendo que en tal hecho pueda ser viable entablar la acción reivindicatoria (CC, art 947). De esta forma, estos planteamientos amparan la confianza del sujeto de derecho 
en la apariencia jurídica y la buena fe sirve de postulado para la adquisición o para el ejercicio de un derecho subjetivo.

c) El último grupo apuntan a la buena fe, como un concepto basado primordialmente en la honradez y rectitud en el trato y presume una manera de proceder de las partes a las cuales deben ajustarse en el desarrollo de las relaciones jurídicas y en la celebración, interpretación y ejecución de los negocios jurídicos (Ponce de León, 2010).

Los anteriores conceptos, entre otras consecuencias, favorecen a integrar el contenido contractual, que se encuentra fundamentado en que la confianza en que deben estar basadas las relaciones jurídicas, legitima las expectativas que cada parte se forma en relación al comportamiento de su contraparte durante la vida de una particular relación contractual.

\subsection{Diferentes conceptos que derivan de la buena fe como principio}

Con respecto a los ordenamientos jurídicos, los principios son partes integrantes y esenciales que contribuyen a la creación y adecuación de estos y a su interpretación. De ahí que se diga que los principios son integrativos, creativos, interpretativos, delimitadores y productores. De acuerdo con Bartole, los Principios Generales del Derecho cumplen las siguientes funciones: “a) integradora, en el sentido de colmar las lagunas del dictado normativo; b) interpretativa, en el sentido de ofrecer al juez el modo de subsumir los presupuestos de hecho en un enunciado amplio; c) delimitadora, en el sentido de poner un dique a las competencias legislativas y negociales; d) productora, en el sentido de ofrecer valores sobre los cuales se funda íntegro del ordenamiento" (Bartole, 1997).

La función creativa se observa según lo que menciona Hinestroza: "En Colombia fue singularmente significativa la intervención de la Sala de Casación civil de la Corte Suprema de Justicia de la segunda mitad de los años 30, que modernizó la concepción, la interpretación y la aplicación del derecho, en esfuerzo simultáneo con las demás ramas del Estado. Así, con mentalidad abierta, introdujo el espíritu de ,jurisprudencia creadora ${ }^{e e}$ y con ella, los 
principios de la buena fe-apariencia, simulación, fraude a la ley, abuso del derecho, responsabilidad civil, imprevisión, móvil determinante, error de derecho, enriquecimiento injusto" (Hinestroza, 2000).

Este mismo agrega que "Los principios generales del derecho han adquirido un valor integrador $^{\text {ee }}$ del ordenamiento, concepciones, sentimientos, anhelos, contenidos, que pueden expresarse con fluidez, sin la virulencia de lo reprimido, de manera de agilizar la acomodación del derecho a la „,modernidad ${ }^{\text {ee }}$, no por afán de modo, sino por exigencia de actualidad, coherencia, justicia. En este sentido pudiera hablarse de ellos como derecho flexible, "evisualización del derecho actual considerándolo desde el punto de vista real dentro de un contexto menos rígido, más justo y razonable; integrando argumentos externos que sin ser estrictamente jurídicos forman parte de su existencia estructural, en aras de una modernización que conlleve a la flexibilización hermenéutica y jurídica en su interpretación.. Por tal razón es inquietante la inclinación, no por explicable menos censurable, a la cristalización de la jurisprudencia, que se observa en distintos medios y ambientes” (Hinestrosa, 2000)

La Constitución Política Colombiana de 1991 en su artículo 230, enseña que los principios generales del derecho son criterios auxiliares en caso de insuficiencia de la ley, es decir, en caso de obscuridad o vacíos normativos, posición anti formalista que influye en la jurisprudencia colombiana desde 1936 -época de la "Corte de Oro"- en una nueva interpretación del artículo 8 de la Ley 153 de 1887, la cual, desde un punto de vista eminentemente influido por la escuela de la libre investigación científica y el conceptualismo alemán, acogió la equidad y los demás principios generales del derecho como punta de lanza para la solución justa de los conflictos jurídicos.

La Corte Constitucional ha considerado que en tanto la buena fe ha pasado de ser un principio general de derecho para transformarse en un postulado constitucional, su aplicación 
y proyección ha adquirido nuevas implicaciones, en cuanto a su función integradora del ordenamiento y reguladora de las relaciones entre los particulares y entre estos y el Estado, y en tanto postulado constitucional, irradia las relaciones jurídicas entre particulares, y por ello la ley también pueda establecer, en casos específicos, esta presunción en las relaciones que entre ellos se desarrollen.

En cuanto a las reglas se observa que desde el derecho romano estas se entendieron como una proposición que expone en forma breve el derecho vigente y eran normas imperativas del ordenamiento. De esta forma, en la Edad Media la concepción de las reglas se extendió, de las contenidas en el derecho vigente a las derivadas del derecho natural, dando origen a los principios no regulares. Por eso éstos y aquellas, se identificaron bajo la denominación común de normas jurídicas. Por su parte, los diccionarios jurídicos suelen definirla como un precepto de conducta establecido en función del deber ser e impuesto por parte de una autoridad constituida legítimamente.

Asimismo, Martha Lucía Neme Villarreal en la revista del derecho privado No. 11 del 2016 hace referencia a las reglas y la buena fe concluyendo que:

“...La fuerza de la buena fe, como principio normativo, integra el contenido del contrato, formándolo permanentemente a través del establecimiento de reglas concretas por virtud de las cuales se otorga la exacta dimensión al contenido de las obligaciones de las partes a la luz de la buena fe o en razón de la reducción o modificación de las previstas en el acuerdo, así como mediante la prohibición del ejercicio abusivo de los derechos.

En este orden de ideas, la buena fe obliga no solo a lo fijado en la convención y a los cuidados generales usuales entre personas honorables, sino a todas aquellas prestaciones accesorias que las circunstancias que rodean el negocio en cada momento vayan poniendo de manifiesto, con independencia de que hayan o no sido 
pactadas expresamente. Por tal razón se agregan al contrato, por ejemplo, obligaciones de información, de vinculación al pacto celebrado, no a la letra sino al verdadero interés de las partes, de lealtad, de diligencia, de cooperación, de transparencia, de solidaridad, de no contrariar los actos propios, etc., todas las cuales por virtud de la fuerza integradora de la buena fe y de su carácter normativo se entienden incorporadas al contrato, atendiendo a la naturaleza del mismo y de las particulares circunstancias del caso sin necesidad de que hayan sido expresamente pactadas por las partes.”

Los principios siempre formaron parte del mundo jurídico pero en los últimos años han adquirido inusitada fuerza, ya que se convirtieron en "un soporte de la interpretación jurídica, pero consultando criterios de objetividad, a través de la misma argumentación, de manera que se pueda recuperar la relación entre derecho y moral, sin dejarla sujeta a la racionalidad subjetiva del intérprete" (Trujilo, 2001). De ahí que los principios no son sino normas fundamentales y generales del sistema, las normas más generales y es indudable que los principios generales son normas como todas las otras.

En este sentido la Corte Constitucional plantea que los principios están ubicados en el plano deóntico, es decir, son normas que contienen prescripciones jurídicas. Por lo tanto el juez, en su estudio, puede “descubrir” las reglas jurídicas contenidas en un principio jurídico. También ha sostenido que los principios “consagran prescripciones jurídicas generales” cuyo alcance normativo no consiste en la enunciación de ideales que algún día puedan alcanzarse. "Los principios, entendidos como concepto deontológico, expresan un deber ser y se manifiestan bajo la forma de mandatos, prohibiciones, permisiones o derechos" (Sentencia T - 191, MP José Gregorio Hernández Galindo, 1994).

Sin embargo, mientras las reglas son normas cuyo texto establece una prescripción que sólo puede ser cumplida o incumplida, los principios son normas que ordenan la realización 
de algo de la mejor manera posible. Para Robert Alexy los principios son "mandatos de optimización”, cuyo cumplimiento no exige una medida determinada sino su mejor grado posible de satisfacción. En tanto tales, los principios "son normas que ordenan que algo se realice en la mayor medida posible según las posibilidades fácticas y jurídicas. Esto significa que pueden ser realizados en diferente grado y que la medida de su realización depende no solo de las posibilidades fácticas sino también jurídicas. Las posibilidades jurídicas de la realización de un principio están determinadas esencialmente, a más de por las reglas, por los principios opuestos. Esto significa que los principios requieren ponderación y esta ponderación es la forma característica de la aplicación de los principios.

En otras palabras los principios solamente juegan en la interpretación cuando la aplicación directa y exclusiva de las reglas no da la solución al problema jurídico, es decir cuando el intérprete está frente a casos difíciles. Sin embargo algunos juristas sostienen que "los principios han de tenerse siempre en cuenta en la aplicación del derecho y sólo después de hacerlo podemos afirmar que un caso es fácil o difícil; un caso es fácil -escribenprecisamente cuando la subsunción de unos hechos bajo una determinada regla no resulta controvertible a la luz del sistema de principios, motivo por el cual, antes de decidir que una norma es concluyente para resolver un caso, siempre es preciso deliberar a partir de las razones que nos proporcionaron los principios, tanto en relación con los hechos como respecto de la norma o regla" (Dworkin, 1978).

En términos generales, la regla es, entonces, una norma jurídica general que se aplica a una situación concreta y especifica. Lo anterior significa que entre reglas y principios existen diferencias, pero también vínculos estrechos y, sobre todo, una jerarquía normativa. Las diferencias residen en que las reglas son normas que se aplican en la forma de "todo o nada", mientras los principios son normas que se aplican, en mayor o menor grado, según el resultado de la ponderación construida por el intérprete. En palabras de Dworkin las reglas 
son aplicables a manera de disyuntivas, mientras que los principios son más bien razones para decidir. Otros juristas sostienen que la diferencia entre reglas y principios es de tipo funcional: Una misma norma puede funcionar como regla o como principio en circunstancias diferentes. La diferencia se encuentra al establecer si el juez aplicó la norma a través de un ejercicio de ponderación con otras o no. En el primer caso la norma funcionará como principio y en el segundo como regla.

Ahora bien, entre principio y valor puede haber más identidades que diferencias. Alexy lo pone de presente apelando al supuesto de la colisión, de manera que toda colisión de principios puede ser presentada como una colisión de valores y viceversa. Sin embargo, en las colisiones de principios se trata de establecer lo debido, mientras que en las de valores se trata de establecer lo mejor. Por lo tanto principios y valores son lo mismo, una vez con ropaje deontológico y otra con ropaje axiológico. En ese sentido resulta que el principio es derecho y el valor es filosofía.

Asimismo, la Corte Constitucional colombiana encuentra que las reglas son "las disposiciones jurídicas en las que se define, en forma general y abstracta, un supuesto de hecho y se determina la consecuencia o consecuencias jurídicas que se derivan de la realización del mismo; una disposición, pues, derechamente construida para regular u ordenar de forma directa la vida humana, la realidad social. Es decir, virtud de esta estructura lógica, las reglas operan como silogismos" (Monroy Cabra, 1987). En ese sentido la regla puede ir más allá de la norma legislada, y un juez puede derivarla de su estudio, o derivar de la relación que establezca entre distintas reglas, una o varias sub-reglas a base de inferencia lógica.

La Corte Constitucional, en interesante providencia de unificación, (Sentencia SU.1122/01), dijo lo siguiente: "La diferencia conceptual entre reglas y principios sugiere varios problemas interpretativos. El carácter preciso de las reglas obliga a preferirlas a la hora 
de enfrentar conflictos con los principios. Empero, una interpretación razonable de las reglas puede llevar a situaciones abiertamente incompatibles con principios, aunque no sean ilegales o ilícitas. Se trata de eventos en los cuales existe la posibilidad legitima de interpretar una regla que puede conducir, entre muchos, a un resultado determinado, el cual no se encuentra prohibido por el ordenamiento, pero resulta incompatible con los principios que sustentan la regla."

Además valores y principios no vinculan de la misma manera a las distintas ramas del poder, ni están sujetos a los mismos criterios de interpretación Los valores tienen "una enorme generalidad y, en consecuencia, una textura interpretativa abierta, dentro de la cual caben varias fijaciones del sentido" (Sentencia T -406 de 1992, M.P. Ciro Angarita Barón). Por lo tanto es muy difícil para el intérprete derivar reglas jurídicas de los valores. De los principios sí, porque son derecho. El desarrollo de los valores corresponde al legislador, el de los principios al juez.

Los valores son un catálogo axiológico de carácter fundante. Sobre ellos se construyen el sentido y la finalidad de la organización política. Su sentido no define lo preferente sino lo preferible. Los valores tienen que ver con las formas ideales y se mueven en función de una cultura social, de una ética pública, de unos elementos a partir de los cuales se construyen las instituciones. El ámbito de los valores, manejados por la vía de la política, conecta el mundo de la ética con el mundo del derecho.

De ahí que con este contexto planteado anteriormente y estrechamente vinculado con la idea moral en el derecho, se encuentra que la buena fe es un principio, ya que aunque no enunciado de una manera general por la ley, tiene tantas aplicaciones en el derecho positivo que sin duda alguna, lo convierten en un principio general del derecho de la mayor importancia. Como dice Íez Picazo, el ordenamiento jurídico exige este comportamiento de buena fe no sólo en lo que tiene de limitación o veto a una conducta deshonesta (v.gr., no 
engañar, no defraudar, etc.), sino también en lo que tiene de exigencia positiva prestando al prójimo todo aquello que exige una fraterna convivencia (v.gr., deberes de diligencia, de esmero, de cooperación, etc.).

Por tanto, la buena fe del agente puede atribuir al acto efectos que éste no tendría en otro caso y, viceversa, la mala fe quita al acto efectos que tendría de no ser así; el mismo acontecimiento produce efectos diversos según el agente tenga buena o mala fe.

Por su parte, la confianza legítima es un principio general del derecho que fue admitido en la Constitución Colombiana de forma implícita, gracias al desarrollo jurisprudencial en relación con el principio de la buena fe, la seguridad jurídica y como desarrollo del Estado Social del Derecho (Lasarte, 1980). Con base en ello y siguiendo a De castro (Ordoqui, 1986)), los principios poseen fuerza normativa, aunque no estén formulados como reglas, son valores, ideas fundamentales e inspiradoras de un orden jurídico.

Se puede afirmar entonces que, de acuerdo con la doctrina y con la jurisprudencia, la confianza legítima es un principio que emana del principio de la buena fe, al punto que algunos autores afirman que la segunda es el género y la primera (Confianza) la especie (Viana, 20). Según la Sentencia T-472/09, la confianza legítima "es un mandato inspirado y retroalimentado por el de la buena fe y otros, que consiste en que la administración no puede repentinamente cambiar unas condiciones que directa o indirectamente permitía a los administrados, sin que se otorgue un período razonable de transición o una solución para los problemas derivados de su acción u omisión.”

La confianza podría decirse que se encuentra intrínseca dentro del principio de la buena fe, si es vulnerada la confianza se estaría causando un perjuicio y es allí donde el Consejo de Estado ha dejado la puerta abierta permitiendo otorgarle efectos indemnizatorios a la vulneración de la confianza legítima, cuando se presenta un grado de certeza del perjuicio causado, pese a que la Corte Constitucional ha sido renuente a aceptar el carácter resarcitorio 
de la vulneración al principio de la confianza legítima. Lo anterior tiene sustento en el pronunciamiento del 5 de diciembre de 2005 en donde el Consejo de Estado aduce que: "Los daños causados como consecuencia de los cambios normativos abruptos, así sean legítimos, puede ser indemnizados cuando el administrado se encuentra amparado por la confianza que es merecedora de protección"

Es así como alrededor del principio de la buena fe se ha procurado a lo largo del tiempo y en distintas latitudes proteger la confianza como principio jurídico, iniciando con la regla latina venire contra factum propium, desarrollada en la teoría de los actos propios, y continuando con instituciones tales como el estoppel, de origen inglés, el verwikung alemán, la teoría de la apariencia, la teoría del abuso del derecho y finalmente la teoría de la culpa in contrahendo.

Una de las teorías en este sentido es la de Venire Contra Factum Proprium, teoría que refiere en otras palabras, que a nadie ha de estar permitido ir contra sus propios actos. Ésta constituye un límite al ejercicio de un derecho subjetivo, de una facultad como consecuencia del principio de la buena fe en el tráfico jurídico.

Son varias las definiciones y explicaciones que se han ofrecido de la doctrina de los actos propios. Así, un autor ha podido decir que "la llamada teoría de los actos propios sanciona la conducta contradictoria, importa un verdadero principio de derecho que constituye una regla derivada de la buena fe, fundándose en el deber de actuar coherentemente" (Borda, 2010). Y, por su parte, Díez expresa que "la exigencia de coherencia del comportamiento es una derivación inmediata del principio general de buena fe”. A su vez, Fueye (2009) la ha definido como "un principio general del derecho, fundado en la buena fe, que impone un deber jurídico de respeto y sometimiento a una situación creada anteriormente por la conducta del mismo sujeto, evitando así la agresión a un interés ajeno y el daño consiguiente”. 
$\mathrm{Al}$ respecto, la doctrina ha sido una respuesta jurisprudencial y doctrinaria a situaciones concretas; por ello, su desarrollo ha sido gradual. En la Sentencia T-475 la Corte Constitucional (1992) afirma: "La doctrina, por su parte, ha elaborado diversos supuestos para determinar situaciones contrarias a la buena fe. Entre ellos cabe mencionar la negación de los propios actos (venire contra factum proprium), las dilaciones injustificadas, el abuso del poder y el exceso de requisitos formales, sin pretender con esta enumeración limitar el principio a tales circunstancias. No es posible reducir la infracción de la buena fe a casos tipificados legalmente. De ahí que la aplicación de este principio suponga incorporar elementos éticojurídicos que trascienden la ley y le dan su real significado, suscitando en muchas ocasiones la intervención judicial para calificar la actuación pública según las circunstancias jurídicas y fácticas del caso".

“Cuando la administración, luego de conceder una licencia de funcionamiento a una persona para el ejercicio de una determinada actividad, luego, sin justificación objetiva y razonable, procede a suspender o revocar dicha autorización, con el quebrantamiento consecuente de la confianza legítima y la prohibición de "venir contra los propios actos". En el caso sub-examine, la vulneración del principio de la buena fe al cual deben ceñirse las autoridades en todas sus actuaciones se ha concretado por la decisión de la Secretaría de Planeación Municipal de Popayán”. Es aquí donde el CONCEJO DE ESTADO enciende la luz y otorga el permiso para demostrar el grado de certeza del perjuicio causado y permite asimilarlo como fuente generadora de responsabilidad administrativa en Colombia, todo lo anterior nos remite al articulo 90 constitución nacional, quien para finalizar logra demostrar los daños antijurídicos por parte de autoridades publicas, el estado responda por los daños causados y repara por esta acción u omisión cometida por el funcionario.

\subsection{Principio de buena fe en las actuaciones de la administración}


La buena fe ha pasado de ser un principio general del derecho para convertirse en un postulado constitucional (CP art. 83). Este trascendental principio exige de los particulares y de las autoridades ceñirse en sus actuaciones a una conducta honesta, leal y acorde con el comportamiento que puede esperarse de una persona correcta ("vir bonus").

La buena fe supone la existencia de una relación entre personas y se refiere fundamentalmente a la confianza, seguridad y credibilidad que otorga la palabra dada. En las gestiones ante la administración, la buena fe se presume del particular y constituye guía insustituible y parámetro de acción de la autoridad. La doctrina, por su parte, ha elaborado diversos supuestos para determinar situaciones contrarias a la buena fe. Entre ellos cabe mencionar la negación de los propios actos (venire contra factum proprium), las dilaciones injustificadas, el abuso del poder y el exceso de requisitos formales, sin pretender con esta enumeración limitar el principio a tales circunstancias. No es posible reducir la infracción de la buena fe a casos tipificados legalmente. De ahí que la aplicación de este principio suponga incorporar elementos ético-jurídicos que trascienden la ley y le dan su real significado, suscitando en muchas ocasiones la intervención judicial para calificar la actuación pública según las circunstancias jurídicas y fácticas del caso.

La administración y el administrado deben adoptar un comportamiento leal en el perfeccionamiento, desarrollo y extinción de las relaciones jurídicas. Este imperativo constitucional no sólo se aplica a los contratos administrativos, sino también a aquellas actuaciones unilaterales de la administración generadoras de situaciones jurídicas subjetivas o concretas para una persona. El ámbito de aplicación de la buena fe no se limita al nacimiento de la relación jurídica, sino que despliega sus efectos en el tiempo hasta su extinción.

El principio de la buena fe incorpora la doctrina que proscribe el "venire contra factum proprium", según la cual a nadie le es lícito venir contra sus propios actos. La buena 
fe implica el deber de observar en el futuro la conducta inicialmente desplegada, de cuyo cumplimiento depende en gran parte la seriedad del procedimiento administrativo, la credibilidad del Estado y el efecto vinculante de sus actos para los particulares. La revocatoria directa irregular que se manifieste en la suspensión o modificación de un acto administrativo constitutivo de situaciones jurídicas subjetivas, puede hacer patente una contradicción con el principio de buena fe y la doctrina de los actos propios, si la posterior decisión de la autoridad es contradictoria, irrazonable, desproporcionada y extemporánea o está basada en razones similares. Este es el caso, cuando la administración, luego de conceder una licencia de funcionamiento a una persona para el ejercicio de una determinada actividad, luego, sin justificación objetiva y razonable, procede a suspender o revocar dicha autorización, con el quebrantamiento consecuente de la confianza legítima y la prohibición de "venir contra los propios actos".

En el caso sub-examine, la vulneración del principio de la buena fe al cual deben ceñirse las autoridades en todas sus actuaciones se ha concretado por la decisión de la Secretaría de Planeación Municipal de Popayán. Los motivos invocados por la Secretaría de Gobierno de la Alcaldía Municipal - queja de los ciudadanos que ven en la práctica del billar en un establecimiento abierto al público un atentado contra las buenas costumbres y la moral de los menores de edad - para solicitar de la primera la suspensión y posterior revocatoria de la resolución 1041 de 1991, no cumplen con los requisitos de racionalidad, proporcionalidad y objetividad necesarios para contradecir legítimamente su propia actuación antecedente. La confianza del titular de la respectiva licencia fue traicionada injustificadamente por la administración, amenazando con causarle cuantiosos perjuicios, dada la inversión hecha por el petente luego de haber obtenido la licencia de funcionamiento.

Con base en ello, es importante anotar que no basta con apegarse a la forma de lo convenido, sino que es necesario observar una dimensión sustancial en el acuerdo atendiendo 
a la naturaleza de la relación jurídica y a las finalidades perseguidas por los contratantes para darle cabal cumplimiento al principio de la buena fe. No se trata, pues, de una valoración meramente formal, o si se quiere literal, del acuerdo suscrito, sino que se exige la observancia de una conducta coherente con lo actuado y en consonancia con el tipo de relación establecida (Badosa, 1993).

Se reitera entonces, que la doctrina de los actos propios constituye una derivación inmediata y directa del principio de la buena fe. Es decir, la buena fe se refiere directamente a la lealtad en el tratar, el proceder honrado y leal, que supone el guardar la fidelidad a la palabra dada y no defraudar la confianza, ni abusar de ella. Por tanto, lo que se persigue conseguir es que las relaciones jurídicas se desenvuelvan, así como también el ejercicio de los derechos, conforme a principios que la conciencia jurídica considera necesarios, aunque no hayan sido formulados.

La exposición anterior conduce a un examen de los presupuestos para la aplicación de la doctrina de los actos propios que son: Una situación jurídica preexistente, una conducta del sujeto, jurídicamente relevante y plenamente eficaz, que suscitó en la otra parte una expectativa seria de comportamiento futuro y una pretensión contradictoria con esa conducta atribuible al mismo sujeto.

La segunda teoría es la de la figura del "estoppel”, que en derecho esta expresión significa impedir o prohibir la contradicción, es decir, por virtud del estoppel una persona que ha realizado un acto o una declaración no puede esgrimir como argumento uno que contradiga esa actitud inicial (Alonso, 1971).

Esta figura pretende evitar que una persona se beneficie de sus propias contradicciones, impidiéndole oponerse válidamente a los resultados que se deriven de actitudes asumidas con anterioridad. Así, el sujeto, queda ligado a sus declaraciones, y a la vez impedido de crear un estado distinto al producido, si con ello infiere prejuicio a los 
demás, que confiados en dicha situación, han contraído una obligación o han afectado de alguna manera su patrimonio (Escobar, 1989). Finalmente lo que pretende proteger esta teoría es la confianza generada en el destinatario a partir de los actos de un individuo, es este, al decir de Moretau, su elemento central (Valbuena, 2008).

La tercera teoría es la figura del "verwirkung”, teoría alemán que hace referencia a la figura consistente en el abandono del ejercicio de una acción o de la inactividad de su titular que genera en terceros la idea de que dicho derecho no se va a ejercer (Wiaecker, 1986). La figura intenta, garantizar los derechos de un individuo, sancionando la conducta desleal del titular de un derecho quien, en una primera actitud, omitió o desistió su ejercicio y posteriormente, contradiciendo esa conducta inicial, procuró su realización.

La referencia hecha por la Corte Suprema de justicia de este concepto, obedece a que se trata de la aplicación concreta de un principio general del derecho que, por esta misma condición, es común a todos los ordenamientos: Es el principio de la buena fe en su relación directa e inmediata con la confianza legítima (Amat, 1995).

Por su parte la teoría de la apariencia, permite que una persona sea inducida a confiar de buena fe en una realidad aparente y en sus consecuencias jurídicas basándose en la apariencia de conformidad frente al derecho que otra persona creó o por lo menos toleró (Alsina, 1935). Resulta justo brindar protección a quien fue engañado por obrar de buena fe y brindarle el mecanismo jurídico que le permita verse resarcido o compensado, trasladando el costo eventual derivado de la situación contraria a derecho en aquel que creó o permitió la apariencia.

La sanción consiste, entonces, en reputar como cierto aquello que es solo aparente, a fin de hacerlo producir efectos similares a los que se producirían si no se tratase de una mera apariencia, frente a aquel que indujo o permitió la equivocación. Al respecto, Perreau (citado en Valbuena, 2008, p. 134) afirma que: “Quien crea o tolera dentro del ámbito de su alcance 
un supuesto de hecho de típica relevancia jurídica, de modo que un tercero, por medio del examen que le es exigible, no puede reconocer este vicio, debe pasar por que el supuesto de hecho sea eficaz contra sí mismo".

Por lo visto anteriormente, afirma Valbuena (2008, p. 136) que la teoría de la apariencia es un intento de "evitar una eventual defraudación de la confianza depositada y el quebrantamiento de la seguridad jurídica y de la buena fe"

Finalmente, la teoría del abuso del derecho se refiere a la relación entre este principio y el principio de la buena fe es tan íntima que Passarelli (citado en Ordoqui 2010, p. 66) afirma tajantemente: "la figura del abuso del derecho pierde cierto sentido pues, existiendo en el derecho subjetivo una prohibición general de ejercerlo para fines contrarios a la corrección, a la buena fe y a la solidaridad, ello de por si vuelve en parte superflua la figura del abuso del derecho" (Alexi, 1998). Se denomina abuso del derecho a la situación que se produce cuando el titular de un derecho subjetivo actúa de modo tal que su conducta concuerda con la norma legal que concede la facultad, pero su ejercicio resulta contrario a la buena fe, la moral, las buenas costumbres o los fines sociales y económicos del Derecho. Igualmente, es el accionar de quien en ejercicio de un derecho actúa con culpa o dolo, sin utilidad para sí y causando daños a terceros (Fernández, 1999).

Adentrándose a los orígenes del abuso del derecho, este resulta ser un hijo de una concepción subjetiva del derecho y no de una concepción objetiva del mismo. Esto se puede evidenciar en sus antecedentes que refieren ciertos y renombrados adagios romanos que han servido a los autores para prohijar o rechazar la figura del abuso del derecho en la experiencia jurídica romana. Se cree que no se podía abusar del derecho por cuanto la noción del derecho en el mundo antiguo era objetiva y no subjetiva, es decir, su función era darle a cada quien lo suyo (ius suum cuique tribuere) y no concederle facultades al individuo (Grosso, 1992). Si el 
derecho no era facultad, no era poder, no era situación de ventaja otorgada por el ordenamiento, entonces, no podía existir abuso del derecho.

La teoría de los actos de emulación sería el antecedente de la noción de abuso del derecho (derecho romano vid. Digesto 8.5.8.5 y D. 43.8.2). La emulación consistió en el ejercicio de un derecho subjetivo con la intención de causar un perjuicio a otra persona o a un bien ajeno. Su teoría se desarrolló propiamente respecto de las relaciones de vecindad y cuando se supera una economía primitiva.

Se tiene la percepción de que se puede explicar el origen del abuso del derecho adoptando la idea según la cual los derechos deben ser ejercitados según su uso normal, de tal manera que no ocasionen a los demás un daño apreciable; y que para determinar la normalidad del uso es necesario tener en cuenta el estado general de las costumbres y de las relaciones sociales que varían según el tiempo y los lugares y que, por eso, debe ser sometido a la apreciación de los jueces. Según Bonfante la teoría del uso normal se inspiró más que en la teoría de los actos de emulación en el concepto de immissio, tratando de establecer una línea de demarcación entre las inmisiones lícitas y las ilícitas.

\subsection{Clases de buena fe}

En el siglo XIX tomó fuerza la discusión doctrinal en torno a la diferenciación entre los conceptos de buena fe objetiva y buena fe subjetiva. Especial atención produjo la disputa surgida en Alemania en torno a 1870, entre BRUNS y WäCHTER, sobre la“buena fe”, enmarcada en las fuentes romanistas (Corradini, 1970). Los citados autores debaten sobre diversos aspectos, entre los que se cuenta la naturaleza ética o psicológica de la "buena fe", sobre su concepto y acerca de si debe ser concebida en modo positivo o negativo.

En este sentido para Wächter, el concepto de "buena fe" indica la simple ignorancia de dañar el derecho ajeno y se consuma en una falsa creencia, determinada por cualquier error (Rechtsgutachten, 1969) sin tener en cuenta la excusabilidad o no del error, en una 
concepción que se denominaría después, subjetiva. Para Bruns, en cambio, la "buena fe" designa la rectitud de la conducta, el espíritu escrupuloso y franco con el cual es necesario estrechar acuerdos y comportarse en el consorcio humano (Bruns, 1970), dentro de una visión que denomina ética, en la que la mirada se dirige al contenido exterior de tal conducta, a aquello que resulta observable y enfatiza en la corrección, la honestidad, por lo que considera irrelevante lo que se piensa, se quiere o se cree, destacando que como sustento de un comportamiento probo y leal debe estar un error excusable. Así mismo, Bruns contrapone a la "buena fe" no solamente el dolo, sino la falta de cuidado, no excusable y la culpa grave ( Bruns, 1970); con lo que desplaza la tesis, originalmente planteada desde una perspectiva, totalmente objetiva al campo del error excusable que se mueve en el ámbito subjetivo que pretendió evitar, por lo que al final la concepción de este autor continuó envolviendo el concepto de buena fe objetiva con parte del manto que cobija a la buena fe subjetiva.

No obstante que no se lograra una neta diferenciación entre las dos posiciones inicialmente contrapuestas, la polémica entre Bruns y Wächter constituye en el derecho moderno el preludio de la separación entre el análisis de la buena fe como convicción sicológica y la buena fe como manifestación concreta de deberes de comportamiento en términos positivos, esto es, como principio ético, aun cuando todavía, por largo tiempo, los estudiosos se mostrarán propensos a referirse a la buena fe subjetiva y a descuidar la profundización del concepto de buena fe objetiva.

Es así como la expresión "buena fe subjetiva", denota un estado de conciencia, un convencimiento; y se dice subjetiva justamente porque para su aplicación debe el intérprete considerar la intención del sujeto de la relación jurídica, su estado psicológico, su íntima convicción; se trata por lo tanto de una idea de ignorancia, de creencia errónea acerca de la existencia de una situación regular, la cual se funda en el propio estado de ignorancia, o en la 
errónea apariencia de cierto acto, que se concreta en el convencimiento del propio derecho o en la ignorancia de estar lesionando el derecho ajeno.

En suma, la buena fe subjetiva consiste en un estado psicológico y no volitivo, cuyo substrato está fundado bien en la ignorancia o en un error (Cristofari, 2009). De ahí que "el comportamiento de una persona pueda ser objetivamente antijurídico; empero el derecho lo considera honrado y justo teniendo en cuenta la situación subjetiva en que su autor se encontraba. El error incide aquí en la titularidad o en la legitimidad de la propia conducta [...] o en la legitimidad de la conducta de la contraparte" (Mossett, 2002).

No obstante, se debe enfatizar en que la buena fe subjetiva no se predica respecto "al contenido o a los efectos de la relación misma" (De los Mozos, 1965), sino que se refiere exclusivamente a la corrección del sujeto dentro de la relación jurídica, esto es, a la conciencia del sujeto en relación con la propia situación, o con la ajena, de la que deriva su derecho, de no estar dañando un interés ajeno tutelado por el derecho.

En cuanto concierne a la buena fe objetiva, se le ha entendido como "principio jurídico que introduce en el contenido de las obligaciones deberes coherentes con un modelo de comportamiento objetivo" (De los Mozos, 1965), el del bonus vir, que se expresa a través de las reglas de honestidad y corrección propias de dicho modelo.

De manera que este tipo de buena fe se erige en regla de conducta fundada en la honestidad, en la rectitud, en la lealtad y principalmente en la consideración del interés del otro visto como un miembro del conjunto social que es jurídicamente tutelado. La buena fe objetiva presupone que se actúe con honradez, probidad, honorabilidad, transparencia, diligencia, responsabilidad y sin dobleces, entre otros deberes que emanan permanentemente de su profuso carácter normativo.

La doctrina resalta con beneplácito que haya sido superada la tendencia prevaleciente por largo tiempo de asimilar la buena fe objetiva, propia de la ejecución de las obligaciones, 
con la buena fe subjetiva inicialmente posesoria y que después se extendiera a otras situaciones que se engloban hoy bajo el nombre de la teoría de la apariencia; tendencia que ha sido sustituida por la clara autonomía de la buena fe objetiva que implica una exigencia de comportamiento "diligente, advertido, pundonoroso, y la consiguiente carga probatoria del sujeto que ha de comportarse así" (Hinestrosa, 2003).

En efecto, ya de tiempo atrás ha sostenido la Corte Suprema de Justicia, puntulamente la Sala de Casación Civil, Bogotá, 1. e diciembre de 1938 (MP:Hernán Salamanca), que "La concepción jurídica de la buena fe tiende a alejarse del criterio que la considera exclusivamente como la creencia de no hacer mal a nadie o de no hacer nada ilegítimo, esto es, como un simple hecho psicológico, de creencia, por un criterio jurídico más actuante y real que estima que la cuestión predominante consiste menos en la creencia misma que en cómo y por qué se cree. Esta concepción profunda, que puede llamarse ético-jurídica, no desprecia la naturaleza psicológica del contenido de la buena fe, especialmente en cuanto constituye una creencia; pero coloca en el mismo plano que corresponde a los elementos morales que permiten calificar la buena fe y constituyen su valor, las características jurídicas que la elevan a la categoría de un verdadero principio de derecho (Francois Gorphe). El derecho y la equidad, lo mismo que las reglas de la buena fe, no son otra cosa que lo que el Pretor prescribía a las partes y al juez bajo el nombre de bona fides para la ejecución y el juzgamiento de la mayor parte de las obligaciones. La aplicación de este criterio a los casos particulares no reposa sobre deducciones lógicas sino sobre una apreciación de valores, esto es, sobre el hecho de que de dos intereses opuestos el uno parezca tener un valor superior y por lo tanto decisivo para fijar la importancia de la prestación debida. La costumbre podrá servir al juez para apreciar la buena fe porque aparece como el resultado de un examen razonable y repetido. En efecto: la buena fe no es el producto de un razonamiento lógico; no 
es tampoco un objeto del saber sino una cuestión de experiencia de la vida y de sentido práctico (Andreas von Tuhr).

Por todo lo expuesto anteriormente, la Corte de Suprema de Justicia sostiene que "la concepción jurídica de la buena fe tiende a alejarse del criterio que la considera exclusivamente como la creencia de no hacer mal a nadie o de no hacer nada ilegítimo, esto es, como un simple hecho psicológico, de creencia, por un criterio jurídico más actuante y real", de manera que la aplicación de este criterio a los casos particulares no reposa sobre deducciones lógicas sino sobre una apreciación de valores, en la que la buena fe no es el producto de un razonamiento lógico; no es tampoco un objeto del saber sino una cuestión de experiencia de la vida y de sentido práctico que impone "considerar la bona fides como una realidad y no simplemente como una intención de legalidad y una creencia de legitimidad".

De la misma manera se puede determinar la buena fe en sentido objetivo y subjetivo, y es por eso que el autor Soto Coaguila afirma que en un sentido objetivo, la buena fe actúa “como regla de conducta, ya que es un estándar jurídico que orienta la actuación ideal del sujeto, lo que determina que se le denomine buena fe-lealtad" (Soto, 2003). Por su parte y en sentido subjetivo la buena fe se refiere a la "intención con que obran las personas o la creencia con que lo hacen, por lo cual se le llama buena fe creencia". Equivalentemente, el autor señala que el rol esencial de la buena fe objetiva es imponer deberes., mientras que el de la buena fe subjetiva es otorgar derechos, (Soto, 2003).

Ahora bien, en lo que se refiere a la buena fe contractual, la doctrina indica que esta tiene aplicación no sólo en la ejecución del acto jurídico, sino además en el desarrollo de las negociaciones y en la formación del contrato, principalmente, por medio del nombrado deber de información. De la misma forma, en esta etapa la buena fe se presenta en el deber de no interrumpir inopinadamente y sin causa los tratos preliminares al contrato, so pena de subsanar los perjuicios que puedan causarse, especialmente por el llamado "daño in 
contrahendo" (Solarte, 2004). De otro lado, y ya en el campo de la ejecución de un contrato perfeccionado debidamente, la buena fe contractual hace florecer un catálogo de deberes de conducta que, conforme con la naturaleza de la relación respectiva, extiende tales deberes asumidos contractualmente por cada parte, con el fin de efectuar el interés contractual de la otra parte. En definitiva, la buena fe sirve como una restricción al ejercicio de los derechos subjetivos, relegando la desviación o abuso en su ejercicio, y estimulando a las partes a ser coherentes en su comportamiento, evitando contrariar sus propios actos, entre otras conductas (Solarte, 2004).

Bajo este entendido, un parangón entre los conceptos de buena fe subjetiva y objetiva se plantea claramente cuando se señala que la buena fe objetiva no supone la creencia o ignorancia que justifica un error (buena fe en sentido subjetivo) sino la aprobación de una conducta o proceder, según el parecer unánime de personas razonables y honradas con base en los usos sociales imperantes en una determinada circunstancia.

\subsection{Principio de la buena fe en la teoría del contrato}

La fuerza obligatoria que por naturaleza posee el contrato permite que cada contratante se encuentre ligado por este, como si la obligación le fuera impuesta por la ley. De esta manera lo expresa Rubén Stiglitz (1994), quien asevera que en virtud de ello, "las partes deben conformarse a la ley del contrato, así como están obligadas a respetar a la ley propiamente dicha" (1994b: 521). Asimismo, este autor añade que visto desde una concepción liberal, que concibe el contrato como un producto donde convergen partes libres y iguales (Stglitz, 1994), la fuerza obligatoria que conlleva el contrato se aplica a las partes y al juez, de tal modo que si la voluntad de las partes ha sido manifiesta claramente, el juez no puede dejar de aplicar las reglas de autonomía incluso cuando vayan en contra de la equidad, por la sencilla razón de que estas cláusulas, por haber sido pactadas voluntaria y libremente por cada una de las partes, no pueden ser cambiadas por quien debe ocupar la condición de servidor respetuoso 
del contrato.

Estos conceptos conllevan ahora al análisis de la buena fe como criterio básico de interpretación de los contratos y es precisamente como la función interpretativa de esta presume, en primer lugar, manifestar un concepto general de interpretación; así, y luego de precisar que en el universo del derecho esta interpretación está dirigida a determinar el significado de los actos encaminados a establecer reglas de disciplina del comportamiento de las personas (normas jurídicas) o a regular los intereses de sus autores (negocios jurídicos), se debe hacer referencia a que la labor interpretativa del contrato se puede emprender tomando como objeto de interpretación la voluntad de negocio de las partes, de donde la actividad de esta persona que funge como intérprete se debe orientar a "buscar ese querer interno", lo que conlleva a "descuidar la exigencia de una tutela razonable de la confianza de la otra parte y, en general, de los terceros" (Scognamiglio, 1983). En contraste, la interpretación se podría ocupar del comportamiento exterior, o bien del significado del negocio desde un punto de vista externo y objetivo, teniendo como resultado un "fortuito sacrificio de la determinación real de las partes".

Continuando con este contexto, se puede decir también que sostiene que el deber general de la buena fe contractual tiene como función básica, satisfacer las lagunas legales que son inevitables al momento de efectuar un contrato, así como el deber de actuar correctamente que existe entre el deudor y el acreedor para este tipo de situaciones ( Galgano,1992). Precisamente este autor añade que la ley, por más analítica que sea, es incapaz de prever todas las posibles situaciones que se presenten, por medio de normas concretas; de la misma manera tampoco pude prever los abusos que las partes puedan realizar una en perjuicio de la otra y es por eso que, el principio de la buena fe permite reconocer prohibiciones y obligaciones diferentes a las que prevé la ley. De ahí que este principio brinda 
criterios para satisfacer esas lagunas que pueden manifestarse en las variadas y múltiples situaciones que ofrece el devenir de la vida económica y social.

Al lado de ello, la buena fe en la etapa de ejecución del contrato juega un papel de complemento, en virtud del cual, el deber y la lealtad de colaboración amplían las obligaciones que nacen del contrato. De ahí que se tenga la buena fe como cimiento de la fuerza obligatoria del contrato y que al tratarse precisamente de la institución del contrato, éste constituye un compromiso de voluntades que obliga a las partes a establecer sus prestaciones respectivas de la manera pactada, pero siendo imperiosa la norma que determina que todos los contratos se deben ejecutar conforme las reglas de la buena fe -lealtad (De la Puente y Lavalle, 2000). Tal norma se implanta por integración en cada contrato, como si fuera una condición del mismo.

El deber de brindar información real en las relaciones contractuales, es calificado por la doctrina como una obligación, necesidad o regla secundaria de conducta, es decir, como una prestación accesoria o instrumental del negocio jurídico que tiene una existencia propia (Betti: 1959). Es así como el principio de la buena fe está en arraigado en la Constitución Nacional en los artículos 20 y 78 de la misma, de tal forma que el artículo 20 garantiza a toda persona la libertad de "informar y recibir información veraz e imparcial" (CN, 1991), y por su parte el art. 78 dispone: "La ley regulará el control de calidad de bienes y servicios ofrecidos y prestados a la comunidad, así como la información que debe suministrarse al público en su comercialización" (CN, 1991). Se observa entonces que se hace énfasis en que los contratantes se deben información pertinente, oportuna, especifica, clara, precisa, comprensible, y que un "contrato perfecto" es todo aquel que se celebra sobre la base de una información plena, impecable y correcta. De la misma forma, se afirma que ante la falta de información, se obtienen "contratos imperfectos", proclives a las nulidades o al aprovechamiento (Mosset y Predecasas, 2006). 
Teniendo en cuenta lo anterior, es posible que sea el usuario de un determinado servicio quien tenga en su poder la información considerada relevante para efectos de establecer los términos en que válidamente se puede celebrar un contrato. Por ejemplo, en materia de contratos que necesitan la expedición de una póliza o de un seguro, y atendiendo a la particular regulación que hace el artículo 1058 del Código de Comercio, la buena fe ha obtenido una relevancia mayor, al punto que en este tema se manifiesta el concepto de ubérrima buena fe, la cual Informa toda la disciplina del seguro y que le exige a las partes actuaciones honradas, honorables y diligentes y, en segundo lugar, desde su deber de obrar con diligencia profesional.

Esta norma fue declarada exequible por la Corte Constitucional en su sentencia C-232 de 1997, que señaló que al asegurador no se le puede exigir que investigue todos los riesgos que contractualmente; que él contrae sus obligaciones en la mayoría de los casos, asume contractualmente, sino que se debe basar solamente en la información que da el tomador.

Es así como Barbero y Ghestin afirman que el asegurador queda a la merced de la declaración de la contraparte y se debe contratar, ordinariamente, en virtud de su sola palabra (Barbero y Ghestin, 1994). En otras palabras esta situación es especial y produce una de las características clásicas del seguro: la de ser un contrato de ubérrima buena fe. Por su parte, la Sala de Casación Civil de la Corte Suprema de Justicia, en sentencia del 1 de junio de 2007, Ponente fue Ruth Marina Díaz Rueda, señaló que la buena fe que se comunica del contrato de seguro es calificada especialmente; de ahí que se sancionan con la nulidad relativa del contrato, todas las reticencias e inexactitudes que deforman el estado real del riesgo, incorporadas en la solicitud de seguro, cuando traicionen esa demandada ubérrima buena fe, salvo que dichas inexactitudes y reticencias hubieran sido conocidas del asegurador o pudiesen haber sido conocidas por él de haber desarrollado ese deber de diligencia profesional inherente a su actividad. 
Como se puede apreciar, en términos generales la buena fe contractual demanda correspondencia entre quienes ostentan la calidad de contratantes (fase precontractual), concretado en observar un comportamiento honesto y leal, al tiempo que se espera que la otra parte se comporte de igual manera (CSJ, 2002). Efectivamente la exigencia de comportarse de una forma u otra no los exonera de las cargas de sagacidad, diligencia y conocimiento, que se traducen en acciones concretas encaminadas a obtener suficiente y adecuada ilustración respecto del contenido y alcance del negocio jurídico a celebrar.

Para concluir este capítulo, queda claro que la buena fe es un principio general del derecho que se aplica en las diferentes fases del contrato, desde el momento inicial, siguiendo el periodo de ejecución que varía conforme con la naturaleza del contrato y a las cláusulas que lo integran, e inclusive en la fase posterior a su ejecución, con acomodo a los deberes previstos, bien sea de manera expresa o de aquellos inherentes al tipo de contratación. Sin más preámbulos debemos resaltar el impecable aporte de la Corte Suprema y el Concejo de Estado.

\subsection{Pronunciamientos Jurisprudenciales sobre el Principio de la Buena Fe}

En materia de incumplimiento contractual, el ordenamiento colombiano y más específicamente la Sentencia C-452/99, dispone que la finalidad de las normas demandadas (Artículo 25. - Inciso 19 y Artículo 30 inciso 12 de la ley 80 de 1993) consiste en asegurar la suscripción del contrato de que se trate luego de que la entidad contratante ha adelantado un proceso de selección dispendioso y oneroso, así como la reparación de los daños que cause el adjudicatario que se sustraiga a la obligación de suscribir el contrato. Desde esta figura, se

puede asegurar que, de manera general, y como lo ha manifestado la Corte en anterior oportunidad, las garantías establecidas en el régimen de contratación, se fundan en "el deber de preservar los derechos que para las entidades públicas emergen con motivo de las operaciones contractuales, que se vinculan necesariamente con la defensa del patrimonio 
público" (Sentencia C-452/99). Además, establecida la finalidad perseguida por las disposiciones acusadas, es evidente que la misma no sólo es legítima sino que encuentra claro asidero constitucional en aquellas normas de la Carta Política que imponen a las autoridades públicas la defensa del interés general, la sujeción al principio de legalidad y la actuación conforme a los principios de eficacia, moralidad, transparencia y economía. La garantía contractual, en tanto es otorgada por bancos o compañías de seguros sometidas a la inspección y vigilancia del Estado, y aparece como un mecanismo serio y eficaz, que se hace efectivo en un tiempo relativo corto, sin necesidad de acudir a procedimientos o instancias posteriores.

Adicionalmente, los tipos de garantías que se exigen en los procesos contractuales han sido específicamente diseñados por las entidades que las otorgan para cubrir el tipo de riesgos que buscan asegurar, motivo por el cual es poco usual que, en caso de hacerse efectivas, no cubran un monto considerable de los perjuicios. Conforme a lo anterior, es claro que la selección efectuada por el legislador no puede ser calificada como una decisión arbitraria, toda vez que existen razones de diversa índole que no permiten afirmar, en forma definitiva, que existen otras opciones que, de manera clara y contundente, alcanzarían la misma finalidad sin mayores costos.

Con base en lo anterior, esta Jurisprudencia plantea un caso donde, el actor demanda el aparte del primer inciso del numeral 19 del artículo 25 de la Ley 80 de 1993 que establece la obligación de los proponentes en los procesos licitatorios o concursos de méritos de prestar garantía de seriedad de sus ofertas. De igual forma, impugna el primer inciso del numeral 12 del artículo 30 de la Ley 80 de 1993, en el cual se determina que si el adjudicatario no suscribe el contrato dentro del término señalado por la Administración, la entidad contratante hará efectiva en su favor la respectiva garantía de seriedad de la oferta (Cifuentes, 1999). 
En este sentido, el demandante considera que las disposiciones acusadas vulneran los artículos $1^{\circ}, 2^{\circ}, 5^{\circ}, 13,25$ y 209 de la Constitución Política, ya que a su juicio, la obligación de prestar una garantía de seriedad de las propuestas dentro de los procesos de licitación o los concursos de mérito impide que la ciudadanía participe, en forma libre y espontánea, en los procesos contractuales y, por tanto, viola el principio constitucional de participación en la "vida administrativa" (C.P., artículos $1^{\circ}, 2^{\circ}$ y 209) y de la buena fe. De la misma forma, señala que la sanción imponible por la no suscripción del contrato (Ley 80 de 1993, artículo 30-12) infringe también el principio de participación, toda vez que, con ella, se penaliza una opción (la de no participar) que se deriva del anotado principio constitucional.

Asimismo, estima que las normas demandadas establecen una discriminación contraria al principio de igualdad (C.P., artículo 13), debido a que sólo aquellos proponentes que constituyen una garantía de seriedad de su oferta pueden participar en el proceso licitatorio correspondiente, mientras que aquellos que no lo hacen resultan discriminados del mismo. Por último, el actor asevera que la anotada garantía infringe la presunción de inocencia (C.P., artículo 29) y el principio de buena fe (C.P., artículo 83). En su opinión, la obligación de constituir tal garantía equivale a presumir el incumplimiento y la falta de seriedad de los oferentes e implica sancionar una conducta sin que ésta haya ocurrido.

De esta manera y según la jurisprudencia constitucional (C-318/98 MP. Carlos Gaviria Díaz, 1998) el principio de buena fe de que trata el artículo 83 de la Carta Política no impide el ejercicio de las facultades del legislador para expedir normas que impongan la adecuación de la conducta de los particulares a sus deberes constitucionales y legales. Efectivamente, sería irrazonable que la Administración no pudiese contar con recursos que le permitan proteger el patrimonio público que resulten lesionados en razón de la conducta de un particular que traiciona la confianza en él depositada por el Estado. 
De otra parte, la Sección tercera de la Sala de lo Contencioso Administrativo del Consejo de Estado, Consejera ponente: Ruth Stella Correa Palacio, el 3 de diciembre de 2007, expresó recientemente:

"En suma, este principio no sólo se trata del cumplimiento de las normas que establecen el procedimiento y el conjunto de principios que informan y orientan la actividad de la contratación pública -respeto de la legalidad objetiva-, sino de la salvaguarda de las garantías en que consiste este derecho y la protección contra la arbitrariedad de la administración.”

Los pronunciamientos de la honorable corte sobre los principios. en especial para el tema que nos ocupa: el principio de la buena fe; sin lugar a dudas nos brinda jurídicamente en los contratos. El manto de protección que arroja la honorable corte es fundamental para que se respete el principio de la buena fe en todas las etapas contractuales, además cuando se prueba la mala fe la castiga.

En materia de gestión contractual del Estado esto implicaría:

Las reglas de la gestión contractual deben ser claras, precisas y deben permitir que se adopten decisiones objetivas y fundamentadas. Esta premisa aplica frente a todas las condiciones de contratación, bien sea para celebrar de forma directa el contrato o para tramitar una convocatoria pública con el objeto de seleccionar al contratista.

En coherencia con el razonamiento anterior, con el fin de garantizar la imparcialidad de las actuaciones, la normatividad interna que adopten las entidades debe permitir que se deje constancia de la actividad que realiza cada una de las áreas involucradas en la gestión contractual, teniendo claridad respecto a la responsabilidad a su cargo, así como de los procedimientos que aplican en cada caso. Ello, con el fin de que se verifique el cumplimiento de TODOS los requisitos previos necesarios para la adopción de las decisiones en esta materia. 
Aunado a lo anterior y con el fin de evitar la arbitrariedad de la administración, el personal responsable de la gestión contractual debe ser idóneo y estar capacitado para asumir su labor u obligación. Es así como en el trámite de los procesos de selección contractual se deberá respetar la presunción constitucional de buena fe, que es principio rector del sistema jurídico mismo.

Así lo ratificó la Sección Tercera del Consejo de Estado, al indicar:

"Por lo demás, la buena fe, en su carácter de principio, incorpora el valor ético de la confianza y lo protege, fundamenta el ordenamiento jurídico, sirve de cauce para la integración del mismo e informa la labor interpretativa del derecho. En el ámbito de la contratación se traduce en la obligación de rectitud y honradez recíproca que deben observar las partes en la celebración, interpretación y ejecución de negocios jurídicos, esto es, el cumplimiento de los deberes de fidelidad, lealtad y corrección tanto en los actos, tratos o conversaciones preliminares enderezados a preparar la producción o formación del contrato, como durante el transcurso y terminación del vínculo jurídico contractual ya establecido.”

La universalidad de este principio dentro del sistema normativo se evidencia también en la legislación civil y comercial, en especial en los artículos 1603 del Código Civil y 835, 863 y 871 del Código de Comercio.

Las inhabilidades e incompatibilidades, de interpretación taxativa y de orden legal, limitan este principio y, por tanto, facultan a las entidades públicas contratantes a rechazar los ofrecimientos que se presenten en trámite de un proceso de selección o en una contratación directa.

Frente al tema, es menester recordar el pronunciamiento efectuado sobre las implicaciones del principio de buena fe, en el trámite de una convocatoria pública (C412/2011): 
“(...) La presentación de las ofertas por parte de los licitantes lleva consigo la manifestación expresa o tácita sobre la veracidad del contenido de los formularios y documentos anexos y, en todo caso, como ya se dijo, en la etapa contractual cobra especial importancia el principio de la buena fe de la entidad y de los proponentes, como principio general de derecho consagrado tanto en el artículo 83 de la Constitución Política, como específicamente en el derecho de los contratos del Estado, en el artículo 28 de la ley 80 de 1993.

La jurisprudencia La Corte Constitucional ha sostenido sobre dicho principio (C 145/2001): "...De todo lo cual se desprende sin mayores esfuerzos del intelecto que el principio es la confianza, expresada en la presunción de buena fe, mientras que las excepciones al mismo, es decir, aquellas ocasiones en las cuales pueda partir el Estado del supuesto contrario para invertir la carga de la prueba, haciendo que los particulares aporten documentos o requisitos tendientes a demostrar algo, deben estar expresa, indudable y taxativamente señaladas en la ley(...)

Desde luego, lo anterior implica que el mencionado principio también tiene sus límites y condicionamientos, derivados de otro postulado fundamental como es el de la prevalencia del interés común. En modo alguno se puede pensar que el principio de la buena fe se levante como barrera inaccesible que impida a las autoridades el cumplimiento de su función, pues mientras la ley las faculte para hacerlo, pueden y deben exigir los requisitos en ella indicados para determinados fines, sin que tal actitud se oponga a la preceptiva constitucional para imponer a la administración o a los jueces la obligación de verificar lo manifestado por los particulares y para establecer procedimientos con arreglo a los cuales pueda desvirtuarse en casos concretos la presunción de buena fe, de tal manera que si así ocurre, con sujeción a sus preceptos se haga responder al particular implicado tanto desde el punto de vista del proceso o actuación de que se trata, como en el campo penal, si fuere del caso (...)". 
$\mathrm{Al}$ respecto, revisando los manuales de contratación (Ver manual en Anexo A) de las entidades no sometidas al Estatuto General de la Contratación, se ha establecido que algunas exigen como requisito de habilitación, la suscripción, por parte del proponente, de pactos de integridad, de probidad o compromisos anticorrupción.

Como desarrollo del principio de buena fe en materia contractual, la Corte Constitucional, citando al Consejo de Estado en Sentencia del 22 de abril de 1996. C.P. Jesús María Carrillo citado en Corte Constitucional sentencia T-209 de 2006 ha comentado "Las exigencias éticas que se extraen del principio de la bona fides, coloca a los contratantes en el plano de observar con carácter obligatorio los criterios de lealtad y honestidad, en el propósito de garantizar la óptima ejecución del contrato que, a su vez, se concreta en un conjunto de prestaciones de dar, hacer o no hacer a cargo de las partes y según la naturaleza del contrato, las cuales comprenden, inclusive, aquella de proporcionarle al contratista una compensación económica para asegurarle la integridad del patrimonio en caso de sufrir un daño antijurídico.

Con buen criterio, el Consejo de Estado ha venido considerando en su extensa jurisprudencia, acorde con la que ya ha sido citada en esta Sentencia, que el principio de la buena fe debe reinar e imperar durante el periodo de celebración y ejecución del contrato, concentrando toda su atención en la estructura económica del negocio jurídico, con el propósito específico de mantener su equivalencia económica y evitar que puedan resultar afectados los intereses patrimoniales de las partes"

Consejo de Estado, Sección Tercera - Subsección C, sentencia de 20 de octubre de 2014, Exp. 24.809, M.P. Jaime Orlando Santofimio Gamboa, ha insistido sobre la buena fe contractual, u objetiva, en los siguientes términos:

“De lo preceptuado en el artículo 871 del Código de Comercio, con redacción parecida al artículo 1603 del Código Civil, se desprende que en todo el iter contractual, esto es antes, durante y después de la celebración del contrato, y aún 
después de su extinción, se impone a los intervinientes el deber de obrar de conformidad con los postulados de la buena fe. En efecto, aquel precepto prevé que los contratos deben "celebrarse y ejecutarse de buena fe, y en consecuencia, obligarán no sólo a lo pactado expresamente en ellos, sino a todo lo que corresponda a la naturaleza de los mismos, según la ley, la costumbre o la equidad natural."

Pero además, como si no fuera suficiente, el artículo 863 de esa misma codificación ordena que "las partes deberán proceder de buena fe exenta de culpa88 en el periodo precontractual, so pena de indemnizar los perjuicios que se causen”, precepto este que en la contratación pública ha de tenerse como un desarrollo del principio general de planeación que debe informar a toda la actividad contractual del Estado. Sin embargo con frecuencia inusitada se cree que la buena fe a que se refiere estos preceptos consiste en la convicción de estar obrando conforme a derecho, en la creencia de que la conducta se ajusta en un todo a lo convenido y, en general, en el convencimiento de que se ha observado la normatividad y el contrato, independientemente de que esto sea efectivamente así por haberse incurrido en un error de apreciación porque se piensa que lo que en verdad importa es ese estado subjetivo consistente en que se tiene la íntima certidumbre de haber actuado bien.

Empero nada más lejano de la realidad que esa suposición porque la buena fe contractual no consiste en creencias o convicciones de haber actuado o estar actuando bien, es decir no es una buena fe subjetiva, sino que estriba en un comportamiento real y efectivamente ajustado al ordenamiento y al contrato y por consiguiente ella, tal como lo ha señalado ésta Subsección, “consiste fundamentalmente en respetar en su esencia lo pactado, en cumplir las obligaciones derivadas del acuerdo, en perseverar en la ejecución de lo convenido, en observar 
cabalmente el deber de informar a la otra parte, y, en fin, en desplegar un comportamiento que convenga a la realización y ejecución del contrato sin olvidar que el interés del otro contratante también debe cumplirse y cuya satisfacción depende en buena medida de la lealtad y corrección de la conducta propia”, es decir, se trata aquí de una buena fe objetiva y "por lo tanto, en sede contractual no interesa la convicción o creencia de las partes de estar actuando conforme a derecho" o conforme al contrato, pues tales convencimientos son irrelevantes porque, habida cuenta de la función social y económica del contrato, lo que en verdad cuenta son todos los actos reales y efectivos que procuran la cabal realización de estas funciones dentro del ámbito de la legalidad y de la lealtad y corrección, esto es, ajustados en un todo al ordenamiento jurídico y a lo convenido."

Martha Lucía Neme Villarreal en la revista del derecho privado No. 11 del 2016 expone lo siguiente según la Corte Suprema de Justicia, Sala de Casación Civil. Sentencia del 2 de agosto de 2001, exp. 6146, M. P.: CARLOS IGNACIO JARAMILLO JARAMILLO.:

“... de igual modo, particularmente por su inescindible conexidad con el asunto específico sometido a escrutinio de la Corte, importa subrayar que el instituto de la buena fe, en lo que atañe al campo negocial, incluido el seguro, es plurifásico, como quiera que se proyecta a lo largo de las diferentes fases que, articuladas, conforman el plexo contractual -en un sentido amplio-: la atinente a la formación del negocio jurídico, lato sensu (fase formativa o genética), la relativa a su celebración (fase de concreción o de perfeccionamiento) y la referente a su desenvolvimiento, una vez perfeccionado (fase ejecutiva; de consumación o postcontractual). Desde esta perspectiva, un sector de la moderna doctrina concibe al contrato como un típico "proceso", integrado por varias etapas que, a su turno, 
admiten sendas subdivisiones, en las que también se enseñorea el postulado de la buena fe, de amplia proyección.

De consiguiente, a las claras, se advierte que la buena fe no es un principio de efimera y menos de irrelevante figuración en la escena jurídica, por cuanto está presente, in extenso, amén que con caracterizada intensidad, durante las etapas en comento, tanto más si la relación objeto de referencia es de las tildadas de "duración” [...] Quiere decir lo anterior que para evaluar si un sujeto determinado actuó o no de buena fe, resulta imperativo examinar, en cada una de las precitadas fases, la conducta por él desplegada, pero de manera integral, o sea en conjunto, dado que es posible que su comporta-miento primigenio, en estrictez, se ciña a los cánones del principio rector en cita y ulteriormente varie, en forma apreciable y hasta sorpresiva, generándose así su inequívoco rompimiento. De allí que la buena fe no se pueda fragmentar, en orden a circunscribirla tan sólo a un segmento o aparte de una fase, por vía de ejemplo: la precontractual-o parte de la precontractual-, ya que es necesario, como corresponde, auscultarla in globo, según se indicó, valorando las diversas oportunidades que los interesados tuvieron para actuar con lealtad, corrección (correttezza) y diligencia, según sea el caso. Al fin y al cabo, sin excepción, ella se predica de la integridad de eslabones que, analizados en retrospectiva, conforman la cadena contractual (iter contractus), rectamente entendida. No es gratuito que el citado artículo 863 del Código de Comercio, expressis verbis, establezca un débito de comportamiento que cobija todo el “... período precontractual”, sin distingo de ninguna especie

Según la Corte Suprema de Justicia, Sala de Casación Civil. Sentencia del 9 de agosto de 2000, exp. 5372, M. P.: JORGE ANTONIO CASTILLO RUGELES, la buena fe exige el deber del respeto de los derechos ajenos y la prohibición del 
abuso de los propios, y así lo ha reconocido la jurisprudencia cuando declara que la condena jurídica de los comportamientos abusivos del titular de un derecho subjetivo se inspira en los postulados de la "buena fe”. Entendiendo como abusivas y, subsecuentemente, generadoras de la obligación indemnizatoria aquellas actividades protegidas por el derecho que se ejecuten anómala o disfuncionalmente, motivadas por intereses inconfesables, ilegítimos o injustos que se aparten de los fines económico-sociales que le son propios o que comportan el ejercicio malintencionado o inútil del derecho subjetivo.

... características arquetípicas de las cláusulas abusivas -primordialmente-: a) que su negociación no haya sido individual; b) que lesionen los requerimientos emergentes de la buena fe negocial-vale decir, que se quebrante este postulado rector desde una perspectiva objetiva: buena fe, probidad o lealtad-, y c) que genere un desequilibrio significativo de cara a los derechos y las obligaciones que contraen las partes".

\section{Teoría del abuso del derecho.}

En torno al principio del abuso del derecho, fue reconocido como una norma tendiente a restringir el ejercicio absolutista de los derechos subjetivos, si se tiene en cuenta que a la luz del liberalismo individualista impeerante en la legislación patria, no había restricción al uso arbitrario de los propios derechos. A la luz de los nuevos postulados, de la mano de la doctrina francesa y de pensadores como León Duguit y Josserand, se pudo dejar sentado que los derechos subjetivos son relativos y no absolutos, esto es, que no se pueden ejercer ilimitadamente, y quienes abusen de ellos en detrimento de los intereses de los demás deben responder por su conducta. 
Con ello, bien se puede establecer que en ese marco, el abuso se constituye en una fuente a la cual se puede recurrir cuando se ejercen los derechos subjetivos con el ánimo de ocasionar un perjuicio, obrando intencionalmente, de manera culposa o contraria al espíritu que guía cada derecho, así como también cuando en forma abusiva se ejercen los derechos fundamentales o se interponen las acciones de orden constitucional con el ánimo de ocasionar un agravio, actuando de manera temeraria. En el nuevo marco constitucional se ha establecido el criterio del abuso según el cual se abusa de un derecho constitucional propio cuando su titular hace de él un uso inapropiado e irrazonable a la luz de su contenido esencial y de sus fines.

\subsection{Características para que exista el Abuso de Derecho.}

La jurisprudencia y la doctrina han determinado que existe abuso del derecho cuando determinada actuación u omisión de un agente, en principio acorde con el ejercicio de un derecho subjetivo, obedece a un ejercicio culposo o doloso del derecho; o cuando resulta desviada del objeto y finalidad que la Ley establece para dicho derecho, y cuyo ejercicio vulnera derechos de terceros.

¿Es necesario probar que quien incurre en un abuso del derecho actuó con culpa o dolo? Aunque es posible acudir a criterios subjetivos -culpa o dolo- para demostrar la existencia de un abuso del derecho, la Corte Suprema de Justicia determinó que también es procedente acudir a criterios objetivos para esta determinación. En consecuencia, si el ejercicio de un derecho resulta excesivo o anormal respecto de la finalidad prevista en la Ley, y si su ejercicio vulnera el derecho de terceros, habrá un abuso del derecho sin importar los motivos de quien lo ejerce.

Así las cosas, la responsabilidad por abuso del derecho es eminentemente objetiva. ¿Qué requisitos se deben cumplir para que se configure la responsabilidad civil en cabeza de quien abusa de un derecho? 
En el contexto de la responsabilidad civil, no basta con que la conducta de determinado agente constituya un abuso del derecho, sino que además quien alega haberse visto damnificado por dicha conducta debe haber sufrido un daño cierto, y debe existir un nexo causal entre el daño sufrido y la conducta imputada al agente por concepto de abuso del derecho.

¿Una acción de responsabilidad por abuso del derecho es eminentemente extracontractual? La Corte Suprema de Justicia ha afirmado que la teoría del abuso del derecho no surge necesariamente de un hecho ilícito, pues un agente determinado puede abusar de sus derechos emanados de un negocio jurídico, por lo que también puede presentarse en el ámbito contractual.

En el ámbito del abuso en materia contractual, según el criterio jurisprudencial dominante, debe darse:

- La existencia del contrato.

- El abuso de la posición dominante: En cuanto a la posición dominante, la jurisprudencia ha señalado que se encuentran en tal situación, quienes tienen un lugar de privilegio en el tráfico de capitales, o en la prestación de bienes o servicios o dedicados a la contratación masiva y estandarizada, como por ejemplo, las empresas dedicadas a la actividad financiera, a la aseguradora y las prestadoras de servicios públicos.

- El perjuicio.

- La relación de causalidad entre el perjuicio y la conducta abusiva.

El abuso del derecho puede configurarse en materia, ya sea en los actos preparatorios, en la formación del contrato, en su ejecución, en su disolución y, aun, en el período poscontractual.

En resumidas cuentas, en materia de los actos jurídicos contractuales bien puede llegarse a configurar el abuso del derecho en cualquier tipo contractual, ya sea en los actos 
preparatorios, de ejecución o incluso en los actos poscontractuales; toda vez que se den los elementos que la Corte Suprema ha dejado establecidos para su configuración, como se dio desde sus primeros fallos en 1899 y en los que, posterior a 1935 y hasta la fecha, ha venido profiriendo en la materia y reforzando a partir de la expedición de la Constitución de 1991; en ella, como queda visto, el abuso del derecho hace parte de los principios constitucionales; de este hecho se infiere que en un Estado social de derecho, como el colombiano, a los individuos se les reconoce la posibilidad de obrar de acuerdo con su voluntad, siempre y cuando respeten el orden jurídico y los derechos de las demás personas, so pena de tener la obligación de resarcir los perjuicios que con la actuación se cause.

La teoría del abuso del derecho que desde 1935 venía dominando en el ordenamiento jurídico colombiano, como criterio auxiliar en la actividad judicial, permitió moderar el exacerbado formalismo dominante desde el siglo XIX. A partir de ese momento se sentó el criterio según el cual una persona no puede abusar de sus propios derechos. Con la Constitución de 1991, esa concepción teórica sufrió un giro radical, al haberse elevado este principio general de derecho a principio de orden constitucional. En forma expresa, el artículo 95 consagró el deber de toda persona de respetar los derechos ajenos y no abusar de los propios; en ese artículo, como lo tiene sentado la jurisprudencia constitucional, subyace un principio fundamental del ordena- miento jurídico que hace imperioso el ejercicio razonable de los derechos constitucionales.

El abuso del derecho frente al nuevo marco constitucional, ya no es un mero criterio auxiliar, sino que es una norma de aplicación directa, a la cual pueden recurrir los falladores como fuente para resolver las situaciones litigiosas, como ocurre precisamente en materia de las acciones constitucionales de tutela y las acciones de inconstitucionalidad y, dentro de ellas, los estados de excepción, hasta donde se ha hecho extensivo el alcance de la teoría 
del abuso del derecho. En este tipo de acciones, una persona como titular de derechos, como el de acción, no puede en forma abusiva ejercer ese derecho con el fin de obtener un provecho o perjudicar a un tercero, como por ejemplo al interponer dos veces la misma demanda, ya sea de tutela o de inexequibilidad, o en materia contractual imponer cláusulas accidentales que vulneren derechos fundamentales.

No obstante la mayor afectación es la iniquidad del derecho, la cual, es uno de los principios más importantes en materia de contratos y obligaciones. Su progreso ha sido esencialmente doctrinal y jurisprudencial.

La evolución de esta teoría se puede resumir en:

1) Quienes señalan que esta teoría se presenta cuando el titular del derecho lo ejercita con el único propósito de causar daño a otro.

2) La que sostiene que ocurre cuando el titular del derecho desvía la finalidad normal del mismo, económica o social,

3) Los que sostienen que simplemente es una contradicción de derechos

En general se dice que ha oscilado entre el criterio subjetivo o psicológico y el objeto o económico social

\subsection{Criterios para la clasificación del Abuso de Derecho}

1. Intencional. La ruptura del equilibrio entre intereses. Es el inicial que inspiró la teoría, adoptado por la Corte Suprema de nuestro país. La intención de dañar supone abuso del derecho no como intención sino por el daño que produce. El sujeto cubre de apariencia jurídica un acto que no debió realizar o que al realizarlo sabía que debía indemnizar a los afectados.

2. Económico. Inspirada en la definición de Ihering, traída por Saleilles, cuando afirma que el abuso se presenta por el ejercicio contrario al destino económico o social del 
derecho subjetivo. Ej. Agotar plazos que no se necesitan solo para perjudicar al contratante contrario o terminar unilateralmente un contrato sin que exista provecho de ello para quien lo termina.

3. Finalista. Joserrand. Todo derecho tiene un fin social y no puede ser desviado de ese fin, contrariando su espíritu y finalidad para la que fue creado, por lo cual cuando se ejerza de tal manera y en perjuicio de otro, deberá resarcirse el daño.

4. Teoría Conciliadora o eclética. Busca un equilibrio entre el absolutismo de los derechos subjetivos y el ejercicio exclusivo de los derechos como función social. Se explicará en consecuencia si un acto es abusivo o no en la medida que exista un motivo legítimo en el ejercicio de su derecho. Una vez determinado el motivo legítimo, se analiza si ese acto se encuadra en el ejercicio normal del derecho o si desborda o desvía su destino individual y social. Ej. Contrato de sociedad es de colaboración y busca un objetivo común. Cuando un acto se destina al beneficio de uno o un grupo, se desvía esa finalidad y constituye abuso.

\subsection{Evolución en Colombia}

Inicialmente las Cortes y los doctrinantes acogieron la teoría del abuso del derecho, desde el criterio intencional, consagrándolo como fuente de obligaciones de creación jurisprudencial. "El que abuse de sus derechos está obligado a indemnizar los perjuicios que cause".

\subsection{La jurisprudencia}

En la actualidad la jurisprudencia ha venido desarrollando este precepto en materia de la denominada "posición dominante", en distintos fallos sobre el ejercicio de la actividad financiera.

Según Martha Lucía Neme Villarreal en la revista del derecho privado No. 11 del 2016, soportada bajo la Corte Constitucional, Sala Primera de Revisión. Sentencia T-321 del $1 .^{o}$ de abril de 2004, M. P.: JAIME ARAÚJO RENTERÍA, se discute lo siguiente: 
"existe o no un abuso de posición dominante la pretensión de un banco de conservar hipotecados en su favor los inmuebles cuya obligación hipotecaria ya ha sido satisfecha, con el propósito de obtener el cumplimiento de otra obligación, a su vez respaldada con una hipoteca diferente, so pretexto de que la primera hipoteca es abierta y sin límite de cuantía, por lo que respaldaría todas las obligaciones presentes y futuras de la cliente frente a la entidad financiera, en relación con lo cual la corte señala "la posición dominante de la entidad financiera le permite a esta incidir no solo en las condiciones en que se celebra el contrato si no también en la ejecución y cumplimiento del mel mismo, por lo cual debe entenderse que se presenta abuso de tal posición cuando,, por acción o por omisión, la entidad saca provecho de los desequilibrios económicos o los índice. Ello muestra que el uso de la posición dominante por parte de la entidad financiera puede traducirse en ciertos eventos en un abuso de los derechos de la misma. Esa traducción opera en aquellos casos en los cuales el banco, abusando de su posición dominante, no solo modifica las reglas de juego establecidas, sino que además hace uso indebido de las prerrogativas que el ordenamiento jurídico le ha atribuido.

En este orden de ideas, constituye ejemplo de abuso del derecho: el ejercicio abusivo del llamado "poder de negociación”, pues como señala La Corte Suprema de Justicia en sentencia del 19 de octubre de 1994, exp. 3972, M. P.: C ARLOS ESTEBAN JARAMILLO SCHLOSS, en la que se plantea el abuso derivado del hecho de que una entidad financiera colocada en posición dominante frente a los usuarios del servicio, exige prestaciones complementarias bajo la modalidad de contratos ligados que, por obra de sus propias cláusulas o debido a la forma como la institución los ejecuta para ventaja suya, redundan en daño para quienes en la práctica se ven obligados a aceptarlos. 
... la ética colectiva, aquella que la sociedad ampara y procura hacer efectiva con su aprobación o con su rechazo, le dispensa holgada cobertura al ordenamiento positivo el cual, sin las ataduras impuestas por indoblegables guiones conceptuales, recoge las normas de comportamiento individual exigibles para asegurar una convivencia social justa [...] y un ejemplo sin duda persuasivo de esa clase de comportamientos irregulares, lo suministra el ejercicio del llamado "poder de negociación" por parte de quien, encontrándose de hecho o por derecho en una posición dominante en el tráfico de capitales, bienes y servicios, no solamente ha señalado desde un principio las condiciones en que se celebra determinado contrato, sino que en la fase de ejecución o cumplimiento de este último le compete el control de dichas condiciones, configurándose en este ámbito un supuesto claro de abuso cuando, atendidas las circunstancias particulares que rodean el caso, una posición de dominio de tal naturaleza resulta siendo aprovechada, por acción o por omisión, con detrimento del equilibrio económico de la contratación.

Especial reproche merece asimismo en particular el ejercicio de la "posición dominante", en cuanto rompe el equilibrio contractual, o se traduce en conducta mediante las que "se saca provecho de los desequilibrios económicos o se induce a los mismos”, como se invidencia en la Corte Constitucional, Sala Primera de Revisión. Sentencia T-321 del $1 .^{\circ}$ de abril de 2004, M. P.: JAIME ARAÚJO RENTERÍA

Así mismo, la jurisprudencia entiende configurado el abuso del derecho en la etapa precontractual, cuando quiera que se abusa del derecho a no contratar:

Cierto que en el marco de las negociaciones no solamente se compromete la responsabilidad que deviene por el incumplimiento de las obligaciones nacidas de 
un vínculo jurídico acabado. Porque siendo verdad que a una relación de esta índole originada en un contrato no se llega siempre de manera instantánea, no conviene mirar con dejamiento todos aquellos pasos que previamente se cumplen a menudo con el fin de lograr ese acuerdo de voluntades que lo caracteriza. Allí, en tal etapa, se realizan esfuerzos de la más variada índole, precisamente encaminados a cristalizar expectativas y planes económicos, notándose la presencia de una serie de encuentros, de contactos, de intercambios de opiniones y de consulta entre las partes, todo lo cual no puede resultar frustrado inicuamente y no más que respaldados por el principio de la libertad contractual; antes bien, la conducta que deben observar quienes así se contactan en pos de un designio contractual deben ajustarla al principio de la buena fe. Traduce esto que cuando alguien abusa del derecho de no contratar, es preciso pasar de largo ante tan cimero postulado de la libertad que se tiene para contratar, y ver entonces comprometida igualmente su responsabilidad civil, la que por tener su génesis en el camino cumplido para llegar a un contrato que finalmente no se produjo, ha dado en denominarse responsabilidad precontractual [...] Por lo mismo, se trata de una responsabilidad que impide "que una parte abuse de su libertad para concluir o no el contrato proyectado, en daño de aquella otra cuyo interés ha sido solicitado por ella"; de modo tal "que una interrupción intempestiva de las negociaciones sin motivo justo (culpa in contrahendo) puede dar derecho a una indemnización por el daño que sea consecuencia de la defraudación de la confianza en la seriedad de los tratos que venían realizándose”.

De manera concreta podemos sintetizar y precisar que se configura el abuso del derecho, según el criterio dominante de la Jurisprudencia de la Corte Suprema cuando:

- Los bienes del ejecutado se embargan en cuantía que exceda los límites legales. 
- Se mantienen medidas que ninguna garantía prestan para la efectividad de la obligación perseguida

- Se comprometen haberes pertenecientes a terceros.

\subsubsection{Procesos en los cuales se denota El Abuso del Derecho en la Jurisprudencia de la Corte Suprema de Justicia.}

a) En el tema de relaciones de vecindad la jurisprudencia obligada es el caso del Molino la Unión, debido a que el movimiento vibratorio de la maquinaria del molino se transmitía a los edificios vecinos (Corte Suprema de Justicia, Sala de Casación Civil, sentencia de 27 de octubre de 1914). El actor demandó la suspensión del movimiento de las maquinas hasta que se hicieran las obras indispensables para que no sufriera daño su casa a consecuencia de la trepidación que a su finca le comunicaba el funcionamiento del molino y la indemnización de los perjuicios sufridos por dicha causa. La Corte encontró el fundamento en el artículo 669 del Código Civil, porque según la definición que de dominio trae tal norma, las facultades inherentes al dominio, pueden ser limitadas no solamente por la ley, sino también por el derecho ajeno y nadie podría poner en duda el derecho que la demandante tiene a que no se le derribe su casa, o se haga ésta inhabitable, a causa de la instalación de máquinas en edificio próximo.

b) En sentencia del año 1937 con ponencia de Arturo Tapias Pilioneta, la Corte insistió en las obligaciones de vecindad con ocasión de agrietamientos producidos en pared divisoria de una propiedad. Para la Corte aquel que cause a sus vecinos un perjuicio que exceda de la medida de las obligaciones ordinarias de vecindad, comete una falta que le hace responsable y debe ser condenado a pagar daños y perjuicios. Hay derecho a indemnización contra el industrial que se instala en un barrio tranquilo 
donde su fábrica viene a suscitar incomodidades graves a sus vecinos por el hollín, el humo, el ruido o los olores.

c) El precedente que enseguida se expone demuestra la aplicación de la teoría del Abuso del Derecho en cuestiones de contaminación ambiental (Corte Suprema de Justicia, Sala de Casación Civil, sentencia del 30 de abril de 1976). Los hechos materia del litigio tienen que ver con que la Sociedad Hilanderías Medellín S.A. demandó a dos compañías, porque en el proceso de producción de azufre, liberaban por las chimeneas gases sulfurosos, que habían causado cuantiosos daños materiales en sus instalaciones. Las demandadas fueron condenadas en ambas instancias a pagar solidariamente una cuantiosa indemnización y para la Corte, la teoría del Abuso del Derecho encuentra su aplicación en actividades que son tanto útiles socialmente (producción industrial) como peligrosas (contaminación ambiental) y los derechos subjetivos pueden ejercerse sin causar daño a los demás. En fin, ante un daño colectivo producto de una actividad útil y necesaria para el desarrollo del país, si alguien lo prueba haber padecido y señala el agente causante de aquél, tiene derecho a ser indemnizado del perjuicio sufrido, salvo prueba de fuerza mayor, o caso fortuito o de la culpa exclusiva de la víctima.

d) (Corte Suprema de Justicia, Sala de Casación Civil, sentencia del 21 de noviembre de 1969). Un distribuidor de cervezas decidió demandar civilmente a Bavaria S.A., porque consideró que el contrato firmado con el consorcio era de compraventa de mercancías y no de agencia comercial y porque el contrato había sido incumplido por la sociedad mencionada. Simultáneamente, el consorcio presentó denuncia penal contra el distribuidor por los delitos de abuso de confianza y otras defraudaciones. El asunto civil fue fallado a favor del consorcio y el asunto penal a favor del distribuidor. La Corte concluyó su análisis precisando que la apreciación de las 
circunstancias que muestran como anormal el ejercicio del deber ciudadano de denunciar delitos, la extralimitación de los móviles y de los fines que inducen a la denuncia, la temeridad y la malevolencia, en una palabra, el Abuso del Derecho, es cuestión de hecho que corresponde al juez en cada caso deducir de elementos objetivos demostrados en el proceso por medio de los cuales se llegue al pleno conocimiento de los objetivos que asistieron al denunciante, teniendo en cuenta que la ley requiere del concurso de los particulares, cuya iniciativa no debe restringirse, pero tampoco usarse para fines que satisfagan intereses o pasiones personales.

e) En destacada sentencia del 24 de mayo de 1980 la Corte diferencio entre el Abuso del Derecho por el ejercicio de un derecho subjetivo y el Abuso del Derecho en el escogimiento de las vías de derecho. La situación fáctica fue la siguiente: dentro de un proceso ejecutivo el ejecutante embargó y secuestró un automóvil del que no era propietario el ejecutado, sino de un tercero. En el incidente de desembargo el juzgado ordenó devolverle el bien mueble al tercero, mas no condenó al ejecutante por los perjuicios ocasionados a aquél, consistentes en el deterioro del vehículo y en lucro cesante por la no explotación comercial del vehículo durante los veinticinco meses en que quedó en poder del secuestre. El tercero demandó al ejecutante en juicio ordinario por el pago de perjuicios ocasionados con el secuestro del automotor. Para la Corte, quien cometa abuso en la elección de las vías de derecho, esto es, en las actuaciones procesales, también debe indemnizar el daño que cause, mas sólo cuando su proceder haya sido temerario o malicioso. Y en cambio, quien es reo del mismo abuso, pero no ya por elección de vías de derecho, es responsable, en principio, siempre que en su actuar haya obrado culposamente, a pesar de que su proceder no pueda calificarse como temerario o malintencionado. Importante distinción la que se extrae de este precedente judicial. 
f) El embargo de bienes del deudor no puede ir más allá de lo que razonable y objetivamente resulte necesario. Sobre este supuesto dijo la Corte Suprema en sentencia del 27 de noviembre de 1998: "El derecho que reconoce el artículo 2488, en su condición de subjetivo, es esencialmente relativo, o sea que la persecución no puede ir más allá de lo que razonable y objetivamente resulte necesario, conforme a mesura de razonabilidad que la propia ley se encarga de determinar, so pena de incurrirse en abuso del derecho y dar pábulo a un factor de responsabilidad. Cuando el actor, pudiendo, no destraba los bienes que ninguna garantía prestan para la efectividad de la obligación perseguida incurre en un abuso del derecho, generador de una responsabilidad civil, y por consiguiente, en tal caso, habrá de indemnizar al deudor así perjudicado.”. Obsérvese, pues, que en esta particular aplicación del Abuso del Derecho, se requiere para entrar en el campo de la responsabilidad, además del perjuicio que se hubiese ocasionado con el embargo desmedido, que el ejecutante haya obrado con temeridad o mala fe y no basta el mero perjuicio o una mera culpa.

g) La Corte Suprema mediante su Sala de Casación Civil, en sentencia del 27 de marzo de 1998, estudia el caso de un usuario del sistema financiero que decide instaurar un proceso de responsabilidad civil contra el actual Banco Agrario, en razón a que éste no efectuó el desembolso de un crédito. Con el préstamo, el usuario iba a cancelar la compra de una embarcación. Para efectos de la concesión del crédito, la entidad bancaria hubo de exigir la constitución de garantías reales sobre inmueble del deudor, así como sobre la motonave, todo lo cual se verificó. Los bienes gravados con las garantías se avaluaron comercialmente en un valor que superó casi cuatro veces al monto del crédito. El banco no efectuó el desembolso del dinero a favor del vendedor, incumpliendo el compromiso adquirido. El vendedor, aduciendo el 
incumplimiento en el pago del precio de la compraventa y con el uso de la fuerza, retiró la nave del muelle e inició un proceso ejecutivo contra el comprador en razón de dos títulos valores que amparaban la totalidad del precio, y un proceso ordinario contra el comprador y la entidad bancaria, solicitando la resolución del contrato de compraventa. El Tribunal, en segunda instancia acepto el contenido de la cláusula contractual según la cual el Banco de manera totalmente discrecional podía abstenerse de hacer el desembolso del dinero; por su parte la Corte resalto la notoria inequidad de tal interpretación, pues con fundamento en esta, se deja al usuario del servicio de crédito en manos de la entidad financiera, que de por sí en una economía de mercado tiene una posición dominante, más cuando se trata del incumplimiento de cláusulas fundamentales del contrato. En síntesis, para la Corte es cláusula abusiva aquella que deja a entera discreción de la entidad bancaria el desembolso del dinero aunque el solicitante haya cumplido exigencias previas y haya constituido garantías a favor de aquélla.

h) En 1955 la Corte sentó las bases del Abuso del Derecho en la revocación del mandato. A un abogado se le otorgó poder para que se constituyera en parte civil dentro de un proceso penal que se adelantaba en contra de una persona que, de manera injustificada, había retenido unos dineros producto de las ventas de unas acciones del poderdante. El abogado llego a un acuerdo con el procesado para la restitución de los dineros, acuerdo que no fue aceptado por el mandante quien decidió, entonces, revocar en forma intempestiva el mandato, sin pagar los honorarios del abogado y los gastos en que éste había incurrido. La Corte sostiene que la doctrina y la jurisprudencia admiten que, aun cuando no exista en la ley positiva ninguna disposición que restrinja el derecho de revocación del mandante, este derecho no es absoluto sino relativo y no puede ejercitarse abusivamente con 
perjuicio del mandatario que ha cumplido honrada y lealmente sus obligaciones; que el derecho de resciliación unilateral existe en los contratos de duración indeterminada como puede ocurrir en el mandato, en la sociedad y el arrendamiento de servicios, pero que ese derecho no puede ejercerse sino con conocimiento de causa, por un motivo legítimo.

i) El 6 de febrero de 1998 la Corte Suprema de Justicia, Sala de casación civil, se pronunció frente al caso de la Constructora Arinco contra Corpavi, por Abuso del Derecho en las prácticas bancarias en razón de la posición dominante que las entidades de crédito ejercen frente a los usuarios de sus servicios financieros y por la exigencia de prestaciones complementarias a los mismos. En otros términos, en este punto puede existir Abuso del Derecho objetivamente, esto es, sin tomarse en consideración elemento subjetivo, en el caso de que exijan prestaciones complementarias a los usuarios del servicio de crédito y que por razones prácticas no cuentan con otra alternativa que aceptarlas, o, como diría el magistrado que redactó ese fallo, porque existe una "explotación abusiva de esa posición de privilegio" o porque "las prerrogativas envuelven una visible desviación de la función de marcado interés social que les es inmanente en su esencia." En el presente caso, la prestación complementaria exigida al usuario del servicio de un crédito fue la constitución de un depósito colateral mediante el abono forzoso del producto del préstamo, de baja remuneración y con disponibilidad restringida para el mutuario y depositante a la vez.

A punto de finalizar esta disertación debe precisarse que la acción por Abuso del Derecho ya no tiene el carácter de subsidiaria, sino que es una acción directa en la medida en que la institución del Abuso del Derecho tiene carácter independiente y autónomo y ya no se 
le ve como un mero apéndice de la responsabilidad civil extra-contractual.(Rengifo García, 2004)

La jurisprudencia de la Corte Suprema dejó planteado que se configura el abuso del derecho cuando se da una desviación o distorsión del espíritu de los derechos, sea porque se ejercen con la fría intención de causar daño, porque no existe un interés actual y propio, o porque se desarrollan con evidente imprudencia o negligencia, entre otros criterios, como los que se dieron con la expedición de la Constitución de 1991, al adquirir los principios el rango de norma de orden constitucional, hecho que significa que el ejercicio absolutista de los derechos queda proscrito de cualquier área del derecho. Esta situación implica que la teoría del abuso del derecho puede darse en cualquier tipo de relación jurídica, pública, privada, comercial, laboral, procesal, etc.

En forma general, queda establecido el criterio dominante de la Corte Suprema de Justicia, según el cual se presenta el abuso del derecho cuando:

1. Un derecho se ejerce con la única intención de causar un daño o sin motivo legítimo, esto es, correctamente en el sentido de la legalidad, pero injustamente; lo que sucede en los actos propiamente abusivos.

2. Cuando se ejerce de una manera mal dirigida, es decir, distinta de su propia y natural destinación o por fuera de sus límites adecuados. Casos en los que la intención maliciosa cede su lugar preferentemente a la desviación en el ejercicio del derecho como elemento estructural de la culpa, siendo estos los llamados "actos abusivos".

Los criterios que adoptó la Corte Suprema, desde sus primigenios fallos hasta la actualidad, pueden darse en cualquier área del derecho, como bien se dejó visto en materia del derecho de litigar, de los embargos excesivos, en la autonomía de la voluntad privada o en el ejercicio de las acciones constitucionales, que fueron los eventos abordados en este 
trabajo; ello, sin desconocer que, en materia comercial, laboral o administrativa también se puede configurar dicha teoría. En todos esos eventos, se deben demostrar los elementos que configuran la responsabilidad civil, como ocurre con el daño, el nexo y la culpa, o en materia constitucional, demostrando la temeridad en el ejercicio de los derechos subjetivos y constitucionales.

Entonces, ¿Qué pasa si el contratista no está de acuerdo con todas las exigencias (ejemplo: garantías) o cláusulas que el contratante quiere dejar en el contrato?, la autonomía de la voluntad quedaría sin piso; ya que el contratista tendría que someterse a lo que el Contratante decida, sin discusiones posteriores a lo que logra plasmar en el mismo contrato (ley para las partes), porque ya quedaría inmerso en él.

Es por ello que en el siguiente capítulo, a través de un referente casuístico, se va a describir cómo el Contratista queda en un estado de indefensión respecto del Contratante, quien impone cláusulas que, muchas veces, no hay lugar a discutir.

\section{Ecopetrol: un caso representativo de abuso del derecho por desconocimiento del principio de la buena fe en el marco de algunas de sus relaciones contractuales.}

\subsection{Ecopetrol y su régimen jurídico.}

Ecopetrol S.A., de ahora en adelante llamado Ecopetrol, es la principal compañía petrolera en Colombia, perteneciendo al grupo de las 39 petroleras más grandes del mundo y siendo una de las cinco principales de Latinoamérica. Dueños absolutos o participantes mayoritarios de la infraestructura de transporte y refinación del país. Cuentan con campos de extracción de hidrocarburos en el centro, el sur, el oriente y el norte de Colombia, dos refinerías, puertos para exportación e importación de combustibles y crudos en ambas costas y una red de transporte de 8.500 kilómetros de oleoductos y poliductos a lo largo de toda la geografía 
nacional, que intercomunican los sistemas de producción con los grandes centros de consumo y los terminales marítimos.

Con respecto a su régimen jurídico, La ley 1118 de 2006 decretó en su artículo 6. “Todos los actos jurídicos, contratos y actuaciones necesarias para administrar y desarrollar el objeto social de Ecopetrol S. A., una vez constituida como sociedad de economía mixta, se regirán exclusivamente por las reglas del derecho privado, sin atender el porcentaje del aporte estatal dentro del capital social de la empresa".

Por otra parte la ley 1150 de 2007 decreto en su Artículo 13 "Principios generales de la actividad contractual para entidades no sometidas al Estatuto General de Contratación de la Administración Pública. Las entidades estatales que por disposición legal cuenten con un régimen contractual excepcional al del Estatuto General de Contratación de la Administración Pública, aplicarán en desarrollo de su actividad contractual, acorde con su régimen legal especial, los principios de la función administrativa y de la gestión fiscal de que tratan los artículos 209 y 267 de la Constitución Política, respectivamente según sea el caso y estarán sometidas al régimen de inhabilidades e incompatibilidades previsto legalmente para la contratación estatal".

Adicionalmente la ley 1474 de de 2011 decretó en su Artículo 93 “Las Empresas Industriales y Comerciales del Estado, las Sociedades de Economía Mixta en las que el Estado tenga participación superior al cincuenta por ciento (50\%), sus filiales y las Sociedades entre Entidades Públicas con participación mayoritaria del Estado superior al cincuenta por ciento (50\%), estarán sometidas al Estatuto General de Contratación de la Administración Pública, con excepción de aquellas que desarrollen actividades comerciales en competencia con el sector privado y/o público, nacional o internacional o en mercados regulados, caso en el cual se regirán por las disposiciones legales y reglamentarias 
aplicables a sus actividades económicas y comerciales, sin perjuicio de lo previsto en el artículo 13 de la presente ley. Se exceptúan los contratos de ciencia y tecnología, que se regirán por la Ley 29 de 1990 y las disposiciones normativas existentes”.

Es así como de acuerdo con lo establecido en la ley 1118 de 2006, 1150 de 2007 y 1474 de 2011 se fija que el Régimen Jurídico Contractual de ECOPETROLS.A., dada su naturaleza de Sociedad de Economía Mixta, es el derecho privado con aplicación de los principios de la función administrativa y de la gestión fiscal, y del régimen de inhabilidades e incompatibilidades previsto para la contratación estatal y por lo tanto todas sus actuaciones contractuales estarán regidas por el derecho privado bajo el manual de contratación interno de la empresa.

\subsection{Manual de Contratación de ECOPETROL S.A.}

Dada la naturaleza jurídica aplicable a Ecopetrol S.A., toda actividad contractual adelantada por esta sociedad de economía mixta se regula bajo su Manual de Contratación (Ver Anexo A), el cual contiene los principios, normas y procedimientos con los cuales se tramitarán los procesos de selección de contratistas y se celebrarán los contratos que requiere para el desarrollo de su objeto social, exceptuando algunas acciones contractuales las cuales no hacen parte del alcance de la presente tesis.

\subsection{Definición de Retención en Garantía.}

Antes de pasar a exponer los hechos con los cuales se ve vulnerado el principio de la buena fe en el derecho privado y específicamente en las actuaciones contractuales con ECOPETROL S.A., se hace necesario detallar el concepto de retención en garantía y su aplicabilidad, la cual hace parte integral de los contratos suscritos con Ecopetrol S.A. 
La retención en garantía es un acumulado de valores retenidos por ECOPETROL hasta la liquidación del contrato, para realizar pagos o atender obligaciones económicas a cargo del CONTRATISTA derivadas de la ejecución del contrato suscrito con ECOPETROL.

Para ello y con el único objetivo de administrar los valores que retiene ECOPETROL a título de Retención en Garantía, el CONTRATISTA es obligado a celebrar un contrato de fiducia mercantil con una compañía financiera debidamente autorizada por la Superintendencia Financiera bajo su costo. En dicho contrato se incorporan todas las observaciones de administración y manejo de recursos, según las previsiones establecidas en el Contrato suscrito con ECOPETROL. Adicionalmente, en él se hace constar que el CONTRATISTA cede de manera incondicional el valor total de las retenciones en garantía a favor de la sociedad fiduciaria (patrimonio autónomo), y que cualquier desembolso con cargo al patrimonio autónomo debe ser autorizado previamente por ECOPETROL.

4.4. Casos en los que se constata el abuso del derecho y violación del principio de la buena fe.

\author{
4.4.1. Contrato MA-0018531 suscrito entre ECOPETROL S.A. y la UNIÓN \\ TEMPORAL PLATAFORMAS PETROLERAS X para el montaje y construcción de \\ facilidades de superficie para proyectos de producción y exploración en la GCO y \\ campos menores asociados a la gerencia.
}

\title{
4.4.1.1. Riesgos cubiertos bajo la retención en garantía y las garantías y seguros.
}

El contrato MA-0018531 en su CLÁUSULA QUINTA - PARÁGRAFO QUINTO establece: 
“RETENCIÓN EN GARANTÍA: Con el único objetivo de administrar los valores que en pesos colombianos y conforme a la Cláusula de Forma de Pago retenga ECOPETROL a título de Retención en Garantía, el CONTRATISTA se obliga a celebrar un contrato de fiducia mercantil con una compañía financiera debidamente autorizada por la Superintendencia Financiera; lo anterior deberá ser acreditado por el CONTRATISTA dentro de los veinte (20) días calendario siguientes a la firma del Contrato.

En el contrato de fiducia mercantil, que deberá ser aprobado por el Gestor Administrativo, se incorporarán todas las observaciones de administración y manejo de recursos, según las previsiones establecidas en este Contrato y las que señale ECOPETROL. Adicionalmente, en él se hará constar que el CONTRATISTA cede de manera incondicional el valor total de las retenciones en garantía a favor de la sociedad fiduciaria (patrimonio autónomo), y que cualquier desembolso con cargo al patrimonio autónomo debe ser autorizado previamente por el Administrador del Contrato.

Todos los costos que demande la constitución y administración del contrato de fiducia mercantil serán por cuenta del CONTRATISTA.

Los valores que conforme a la Cláusula sobre Forma de Pago se retengan por este concepto y se giren a la fiduciaria se entienden como saldos a favor del CONTRATISTA, a quien corresponderán igualmente los rendimientos que se generen.

No obstante lo anterior, el valor que conformará el patrimonio autónomo, no podrá ser entregado por la sociedad fiduciaria al CONTRATISTA o a terceros, hasta tanto ECOPETROL de manera expresa lo autorice por escrito, previo el cumplimiento de los requisitos que se establecen para el pago final. ECOPETROL podrá disponer libremente 
de los dineros que se depositen en el patrimonio autónomo, para realizar pagos o atender obligaciones económicas a cargo del CONTRATISTA derivadas de la ejecución del presente Contrato, conforme a las estipulaciones contenidas en el mismo, por lo que en el contrato de fiducia mercantil deberán figurar como beneficiarios además del CONTRATISTA, ECOPETROL y terceros. El CONTRATISTA autoriza a ECOPETROL para ordenar en cualquier momento a la sociedad fiduciaria, efectuar pagos directos a terceros (relacionados con obligaciones económicas a cargo del CONTRATISTA derivadas de la ejecución del presente Contrato) con cargo a los recursos depositados en la fiducia mercantil. Será obligación incondicional de la sociedadfiduciaria, devolver en cualquier momento y en forma inmediata a ECOPETROL los dineros que no se autorice entregar al CONTRATISTA, una vez exista orden escrita para ello por parte de ECOPETROL.

Se aclara que de no existir reclamaciones ni cifras imputables a la retegarantía, cada seis meses contados a partir de la emisión de la primera orden de trabajo se realizará el análisis del estado del contrato y autorizará, de ser el caso, la liberación de la retegarantía en un porcentaje máximo del $80 \%$ de lo allí depositado en ese periodo. Lo anterior previa presentación y gestión por parte del CONTRATISTA de un certificado de la oficina de gestión social del área de influencia de la ejecución de las ordenes de trabajo del periodo a liberar, de fijación y desfijacion de la notificación”.

Esta retención en garantía se da con el propósito de cubrir los riesgos relacionados a continuación y que se derivan de la ejecución del contrato:

a) No cumplimiento de obligaciones del Contratista emanadas del contrato

b) No pago de salarios, prestaciones sociales e indemnizaciones laborales. 
c) Mal manejo y cuidado de los bienes entregados por ECOPETROL.

d) Daños materiales, lesiones personales y/o muerte que se ocasionen a terceros.

A su vez, el contrato MA-0018531 en su CLÁUSULA DÉCIMA - GARANTÍAS Y SEGUROS establece:

Dentro de los cinco (5) días hábiles siguientes a la suscripción del Contrato, el CONTRATISTA deberá constituir por su cuenta, ante una compañía de seguros legalmente autorizada para funcionar en Colombia, y entregar a ECOPETROL:

Una Garantía de Cumplimiento otorgada a favor de ECOPETROL S.A., que se rija por el Clausulado General de la Garantía Única de Cumplimiento anexo, y que contenga los siguientes amparos:

a) De Cumplimiento de las obligaciones emanadas del Contrato, que garantice el cumplimiento de todas y cada una de las obligaciones a cargo del CONTRATISTA, el pago de la cláusula penal de apremio y de la cláusula penal pecuniaria, y que tenga: Un valor asegurado igual al 10\% del valor estimado de la orden de trabajo emitida, y Una vigencia igual al término de vigencia de la orden de trabajo y un (1) mes más. Es decir: la vigencia de la póliza debe ser igual a la sumatoria del plazo de ejecución, más el plazo de liquidación de mutuo acuerdo de la orden de trabajo, más un (1) mes.

b) De pago de salarios, prestaciones sociales e indemnizaciones laborales al personal vinculado para la ejecución del Contrato, que tenga: un valor asegurado igual al $5 \%$ del valor estimado de la orden de trabajo, y una vigencia igual al término de vigencia de la orden e trabajo y tres (3) años más. Es decir: la vigencia del amparo debe ser igual a la 
sumatoria del plazo de ejecución, más el plazo de liquidación de mutuo acuerdo de la orden de trabajo, más tres (3) años.

c) De calidad de los servicios, que tenga: Un valor asegurado igual al 10\% del valor final de la orden de trabajo, y una vigencia que comprenda el plazo de liquidación de la orden de trabajo de común acuerdo y un (1) año más, contada desde la fecha de terminación de la orden de trabajo.

d) De estabilidad de la obra, que tenga:Un valor asegurado igual al 10\% del valor final de la orden de trabajo, y una vigencia de cinco (5) años contados a partir de la fecha de terminación de la orden de trabajo.

e) De correcto funcionamiento de los equipos suministrados, vendidos, instalados, reparados por el CONTRATISTA, que tenga: Un valor asegurado igual al $10 \%$ del valor estimado de la orden de trabajo, una vigencia igual al término de vigencia de la orden de trabajo y un (1) mes más. Es decir: la vigencia del amparo debe ser igual a la sumatoria del plazo de plazo de ejecución, más el plazo de liquidación de mutuo acuerdo de la orden de trabajo, más un (1) mes.

f) De buen manejo y cuidado de los bienes entregados por ECOPETROL S.A. para la ejecución de la orden de trabajo, que tenga: Un valor asegurado igual al $10 \%$ del valor estimado de la orden de trabajo, una vigencia igual al término de vigencia de la orden de trabajo y un (1) mes más. Es decir: la vigencia del amparo debe ser igual a la sumatoria del plazo de ejecución, más el plazo de liquidación de mutuo acuerdo de la orden de trabajo, más un (1) mes... 
A continuación se ilustra en un gráfico el excesivo cubrimiento de riesgos que fue advertido en el contrato MA-0018531.

Tabla 1. Paralelo entre garantías.

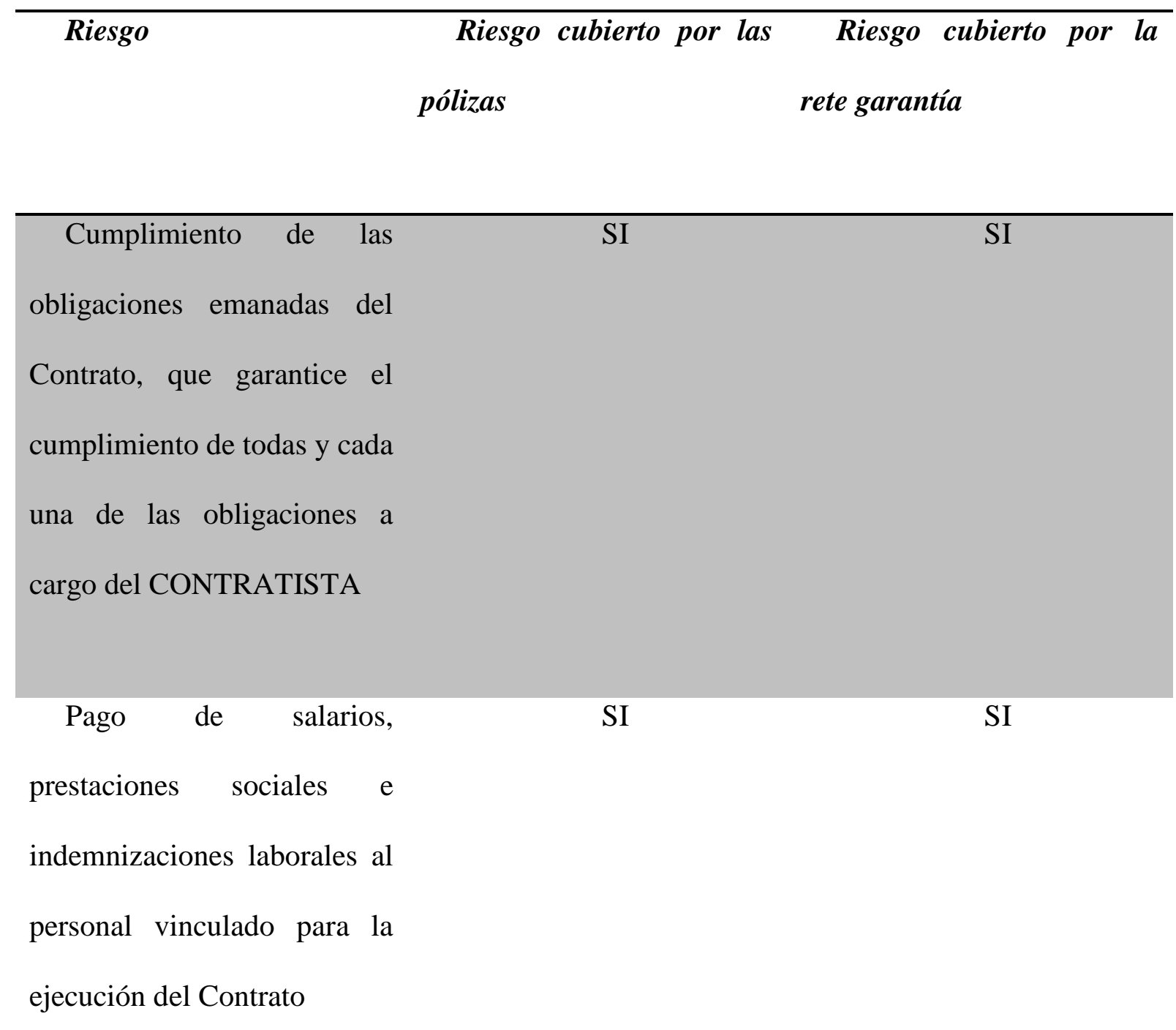

$\begin{array}{ccc}\text { Estabilidad de la obra } & \text { SI } & \text { SI } \\ \text { Correcto funcionamiento } & \text { SI } & \text { SI } \\ \text { de los equipos suministrados, } & & \\ \text { vendidos, instalados, } & & \\ \end{array}$


reparados por el

CONTRATISTA

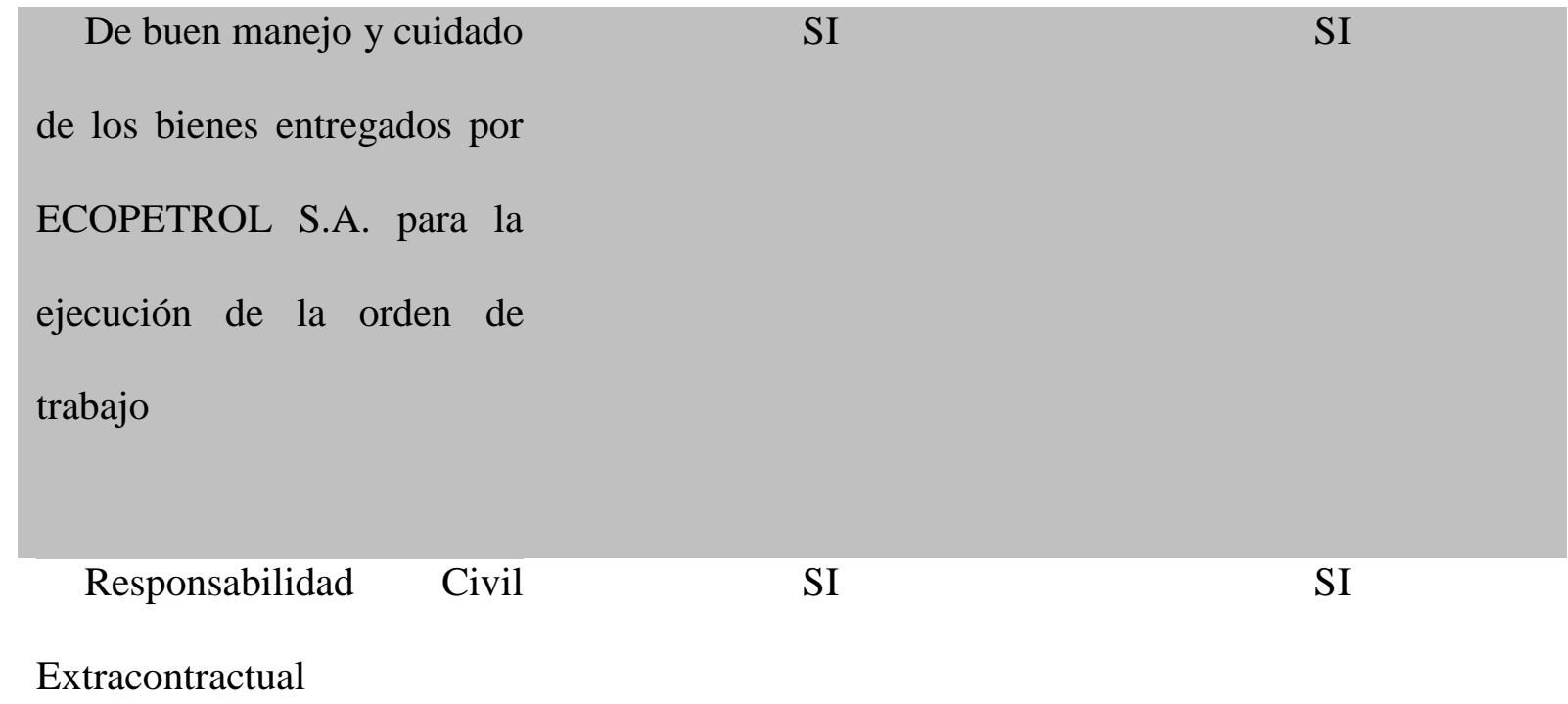

$\begin{array}{llll}\text { Costo por constituir la } & \$ 47.062 .350 & \$ 17.240 .000\end{array}$ cobertura

Ahora bien, según el paralelo realizado entre la CLÁUSULA QUINTA - PARÁGRAFO QUINTO y la CLÁUSULA DÉCIMA se advierte la vulneración del principio de la buena fe con el excesivo cubrimiento de obligaciones tales como; i) el cumplimiento de obligaciones del Contratista emanadas del contrato; ii) pago de salarios, prestaciones sociales e indemnizaciones laborales; iii) Buen manejo y cuidado de los bienes entregados por ECOPETROL; iv) Daños materiales, lesiones personales y/o muerte que se ocasionen a terceros; toda vez que los riesgos cubiertos por la garantías y seguros se vuelven cubrir los montos retenidos como rete garantía en la forma indicada en la CLÁUSULA QUINTA PARÁGRAFO QUINTO que enuncia “ RETENCIÓN EN GARANTÍA: Con el único 
objetivo de administrar los valores que en pesos colombianos y confirme a la Cláusula de Forma de Pago retenga ECOPETROL a título de Retención en Garantía, el CONTRATISTA se obliga a celebrar un contrato de fiducia mercantil con una compañía financiera debidamente autorizada por la Superintendencia Financiera; lo anterior deberá ser acreditado por el CONTRATISTA dentro de los veinte (20) días calendario siguientes a la firma del contrato...”(Ver Anexo B). Para el caso que nos ocupa, estas clausulas poseen la característica de estar reservadas exclusivamente para Entidades Estatales. Toda vez que son inoperantes para contrataciones de Índole privado.

\subsubsection{Eventos contractuales del contrato MA-0018531.}

i) El 6 de noviembre de 2012 se suscribió el contrato MA-0018531 con un plazo de ejecución hasta el 31 de diciembre de 2013 (aproximadamente 600 días calendario) y un plazo de liquidación de mutuo acuerdo de 4 meses.

ii) El 31 de diciembre de 2013 se suscribió el contrato adicional No. 1 al contrato MA0018531 ampliando el plazo de ejecución del contrato en 365 días.

iii) El 24 de noviembre de 2014 se suscribió el contrato adicional No. 3 donde se estableció que el plazo de ejecución del contrato seria hasta el plazo de ejecución de la última Orden de Trabajo suscrita.

iv) El 26 de mayo de 2015, finalizo la última Orden de Trabajo suscrita, entendiéndose como fecha de terminación del contrato MA-0018531 el 26 de mayo de 2015 e iniciándose la etapa de liquidación de mutuo acuerdo por un término de 4 meses.

v) El 25 de agosto de 2015 se suscribió el Otrosí No. 1 al contrato MA-0018531 con el fin de ampliar el plazo de liquidación de mutuo acuerdo por 60 días calendario. 


\subsubsection{Reflexión sobre el abuso del derecho y el desconocimiento de la buena fe en el contrato MA-0018531}

La desconfianza por parte de ECOPETROL S.A. hacia el CONTRATISTA incrementa ineficientemente la cantidad de términos explícitos a considerar por las partes en el contrato MA-0018531, resaltándose en este obligaciones como la constitución de un contrato de fiducia mercantil para el recaudo de una rete garantía y la constitución de una garantía de cumplimiento otorgada a favor de ECOPETROL S.A., ambas con el fin de cubrir los riesgos por i) cumplimiento de obligaciones del Contratista emanadas del contrato; ii) pago de salarios, prestaciones sociales e indemnizaciones laborales; iii) Buen manejo y cuidado de los bienes entregados por ECOPETROL; iv) Daños materiales, lesiones personales y/o muerte que se ocasionen a terceroso.

Ahora bien, como lo indica el PARÁGRAFO QUINTO de la CLÁUSULA QUINTA y el litera f de la CLÁUSULA DECIMA del contrato MA-001853, los costos por la expedición del contrato de fiducia y de las garantías y seguros, sus adiciones o prorrogas serán exclusivamente a cargo del contratista. Estas prorrogas ocurren por imprevistos no controlables por la empresa tales como condiciones climáticas adversas que no permiten cumplir los tiempos establecidos, protestas de la comunidades, cambios en la ingeniería, cambios en el alcance del proyecto, entre otros. Lo anterior incrementa en sobre manera los costos de transacción reduciendo así la utilidad del contratista presupuestada.

Es así como el desconocimiento de la buena fe en el contrato MA-0018531 reduce la utilidad del CONTRATISTA al tener que incurrir en sobrecostos por prórrogas en las pólizas de cumplimiento derivadas de ampliaciones de plazos de ejecución y liquidación además de tener que costear un mayor tiempo de administración de la fiducia, situación que no puede ser prevista 
con antelación ya que el contrato estipula una fecha de terminación para el mismo y no determina hasta cuando Ecopetrol finalmente liquida este.

\subsubsection{Otros aspectos donde se evidencia la vulneración del principio de la buena fe en el contrato MA-0018531.}

La CLAUSULA SEXTA.- OBLIGACIONES DEL CONTRATISTA en su numeral 4 indica:

"El CONTRATISTA es libre de establecer el número de personas a utilizar en la ejecución del Contrato, de acuerdo con el enfoque de organización que dé al mismo, no obstante lo anterior, durante la ejecución del Contrato el CONTRATISTA deberá contar como mínimo con el Equipo de Trabajo que se describe a continuación..”. el numeral 34 de la misma clausula establece "Abstenerse de sustituir a los miembro(s) del Equipo de Trabajo, sin previa autorización expresa y escrita otorgada por el Gestor de la Orden de trabajo, incluido(s) en la propuesta presentada por el CONTRATISTA, cuando la presencia de dicho personal fuere requerida de acuerdo con lo exigido en la CEC, en este Contrato, en sus anexos, en la propuesta, o en el cronograma de trabajo aprobado por ECOPETROL S.A."

Por otro lado, el contrato establece en su CLÁUSULA NOVENA.- PERSONAL numerales 3 y 6 :

3. En caso de que el CONTRATISTA requiera sustituir alguno $(s)$ de los integrantes del Equipo de Trabajo (personal) que fue objeto de evaluación durante el PS (para cumplimiento de requisitos mínimos o para la asignación de puntaje), o cuya presencia fuere necesaria de acuerdo con las CEC, este documento u otro documento 
contractual, deberá solicitarlo a través de escrito dirigido al Gestor Administrativo del Contrato en el cual indique, como mínimo:

a) Cuál es la persona que requiere sustituir;

b) Nombre, títulos y experiencia de la persona propuesta para ocupar el cargo del sustituido, $y$

c) El escrito debe estar acompañado de la documentación soporte que permita verificar la información contenida en aquel.

Para que ECOPETROL S.A. autorice la sustitución en cuestión, el personal reemplazante deberá reunir, cuando menos, las mismas características del que fue objeto de evaluación y que va a ser reemplazado, es decir, debe cumplir con todos los requisitos mínimos y obtener el mismo puntaje que el obtenido por la persona a reemplazar, de ser evaluado de conformidad con las CEC, o cumplir con los requisitos estipulados para el perfil en cuestión.

El Gestor Administrativo del Contrato se pronunciará por escrito en relación con las solicitudes de sustitución de personal dentro de los cinco (5) días hábiles siguientes a la radicación de la totalidad de la información requerida en el Contrato para autorizar la sustitución en cuestión.

Si el Gestor Administrativo del Contrato no se pronuncia dentro de dicho plazo, se entenderá que aceptó la solicitud de sustitución de personal. Si el Gestor 
Administrativo del Contrato se niega a autorizar la sustitución, deberá indicar las razones.

ECOPETROL S.A. se reserva el derecho de ser el único que pueda determinar si cualquiera de los ingenieros o técnicos del CONTRATISTA está o no adecuadamente capacitado y el CONTRATISTA se compromete a reemplazarlo en cuanto el representante de ECOPETROL S.A. así lo solicite, todo ello de acuerdo con los requisitos mínimos de experiencia contenidos en los DPS

Es así como ECOPETROL vulnera el principio de buena fe al obligar al contratista a contratar personal con unos perfiles específicos seleccionados por ECOPETROL, cuyas contrataciones laborales requieren de una autorización previa de ECOPETROL y al igual que su contratación, no pueden ser retirados o reemplazados sin previa autorización. Es evidente que ECOPETROL adopta una posición dominante en donde se advierte que no confía en la experiencia certificada, ni el conocimiento que el mismo auditó al contratista al momento de presentar su oferta.

La buena fe se fundamenta en confianza negocial, transparencia contractual, lealtad en todo acto generado de las parte frente al contrato, las anteriores no se advierten en la imposición de Ecopetrol al contratistas cuando se exige que todo ingreso y salida del personal debe pasarse para visto bueno de ECOPETROL S.A 


\section{UNIÓN TEMPORAL PLATAFORMAS PETROLERAS $X$

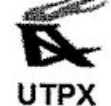

Tibú, 03 de Enero de 2015.

UTPX-MA0018531- GEOCOL-OT4050964-064

\begin{tabular}{|c|c|}
\hline Para: & $\begin{array}{l}\text { GEOCOL } \\
\text { GUSTAVO LEON CELIS } \\
\text { COORDINADOR GESTORIA ADMINISTRATIVA GCO } \\
\text { TIBU, NORTE DE SANTANDER }\end{array}$ \\
\hline De: & $\begin{array}{l}\text { UTPX } \\
\text { ING. CESAR AUGUSTO DUARTE GARZÓN } \\
\text { UNION TEMPORAL PLATAFORMAS PETROLERAS X }\end{array}$ \\
\hline ASUNTO: & PRESENTACION HOJA DE VIDA OT4050964 \\
\hline REF: & $\begin{array}{l}\text { OT } 4050964 \text { Contrato N } N^{\circ} \text { MA0018531 "CONTRATO MARCO PARA MONTAJE Y } \\
\text { CONSTRUCCION DE. FACILIDADES DE SUPERFICIE PARA PROYECTOS DE } \\
\text { PRODUCCION Y EXPLORACION EN LA GCO Y CAMPOS ASOCIADOS A } \\
\text { ESTA GERENCIA." }\end{array}$ \\
\hline
\end{tabular}

Respetado Doctor:

Se adjunta Hoja de vida, para su revisión y aprobación:

\begin{tabular}{|c|c|c|}
\hline NOMBRE & CEDULA & CARGO \\
\hline LEONARDO MACIAS LOZADA & 91.433 .122 & RESIDENTE INSTRUMENTISTA \\
\hline
\end{tabular}

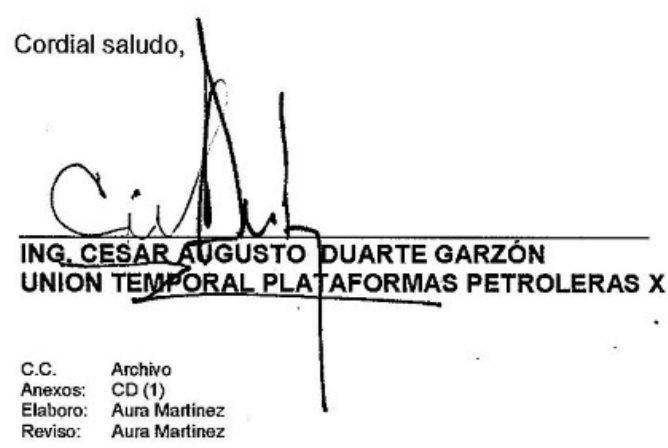

(a)

Calle 16 \#7-81 Barrio Intermedio (Tibú)

Cel. 3212418668 gerenciagco@utpx.co

Figura 1. Comunicación de UTPX para GCO 


\begin{tabular}{|c|c|c|c|}
\hline \multirow{3}{*}{ THPTROL } & \multicolumn{3}{|c|}{ CERTIFICACIÓN CUMPLIMIENTO DE PERFILES } \\
\hline & \multicolumn{3}{|c|}{$\begin{array}{l}\text { ASEGURAMIENTO DE OBLIGACIONES LABORALES } \\
\text { DIRECCION DE RELACIONES LABORALES }\end{array}$} \\
\hline & $\begin{array}{c}\text { CODIGO } \\
\text { ECP-DRL-F-034 }\end{array}$ & $\begin{array}{r}\text { Elaborado } \\
04 / 07 / 2014\end{array}$ & $\begin{array}{c}\text { Versión } \\
4\end{array}$ \\
\hline
\end{tabular}

Este documento tiene como propósito certificar a ECOPETROL S.A., que UNION PLATAFORMAS PETROLERAS $X$, en adelante EL CONTRATISTA, y cada uno de sus integrantes, cuando se trate de Contratista Conjunto, que el(los) candidato(s) propuesto(s) para el cargo de INSTRUMENTISTA para el

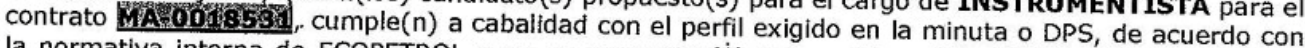
la normativa interna de ECOPETROL y no se encuentra(n்) incurso(s) en inhabilidad, incompatibilidad, impedimento legal o conflicto de interés alguno para desempeñar la posición a la que aspira(n).

Listado de personal:

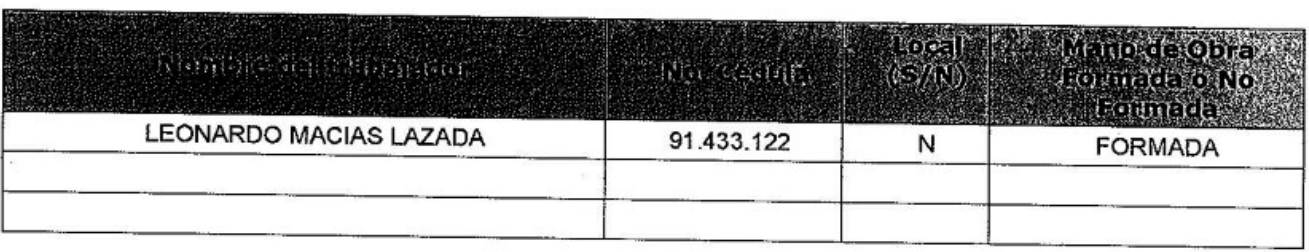

Manifestamos que autorizamos a ECOPETROL S.A. para que, directamente o por intermedio de las personas que designe, verifique y confirme la información acá suministrada. Igualmente autorizamos a ECOPETROL S.A. para solicitar a cualquier entidad pública o privada y a cualquier autoridad jurisdiccional la información necesaria para verificar lo aquí manifestado.

Finalmente confirmamos la autenticidad de la información aquí consignada y somos conscientes de las consecuencias derivadas de la falta de veracidad.

Wilkon Cids Erentes
ELABORO:WILSONCELIS FUENTES

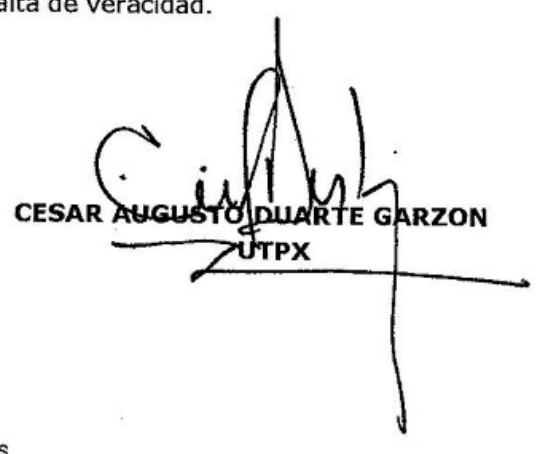

Figura 2. Comunicación de Ecopetrol para UTPX 
EL ABUSO DEL DERECHO Y EL DESCONOCIMIENTO DE LA BUENA FE

106

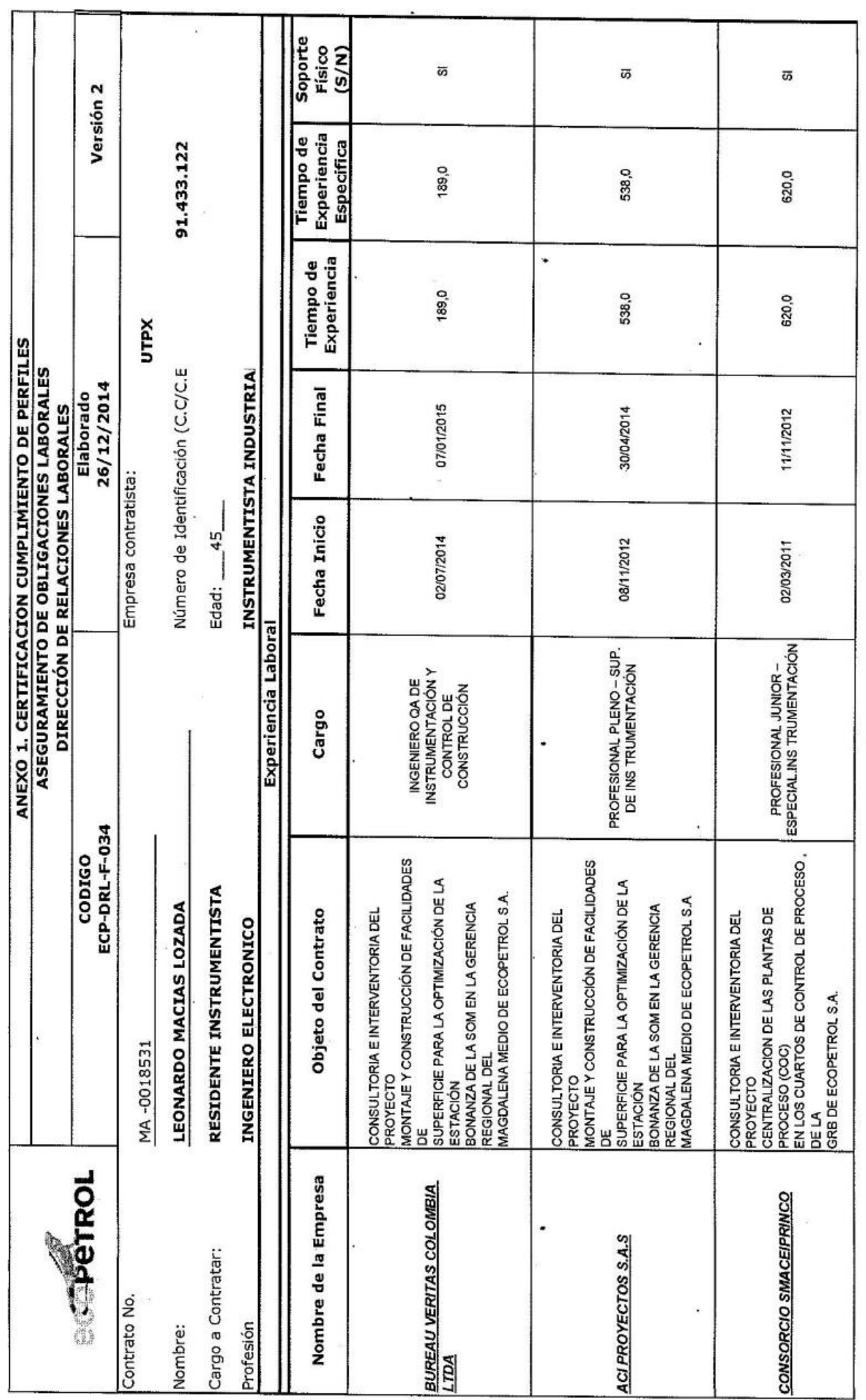


EL ABUSO DEL DERECHO Y EL DESCONOCIMIENTO DE LA BUENA FE

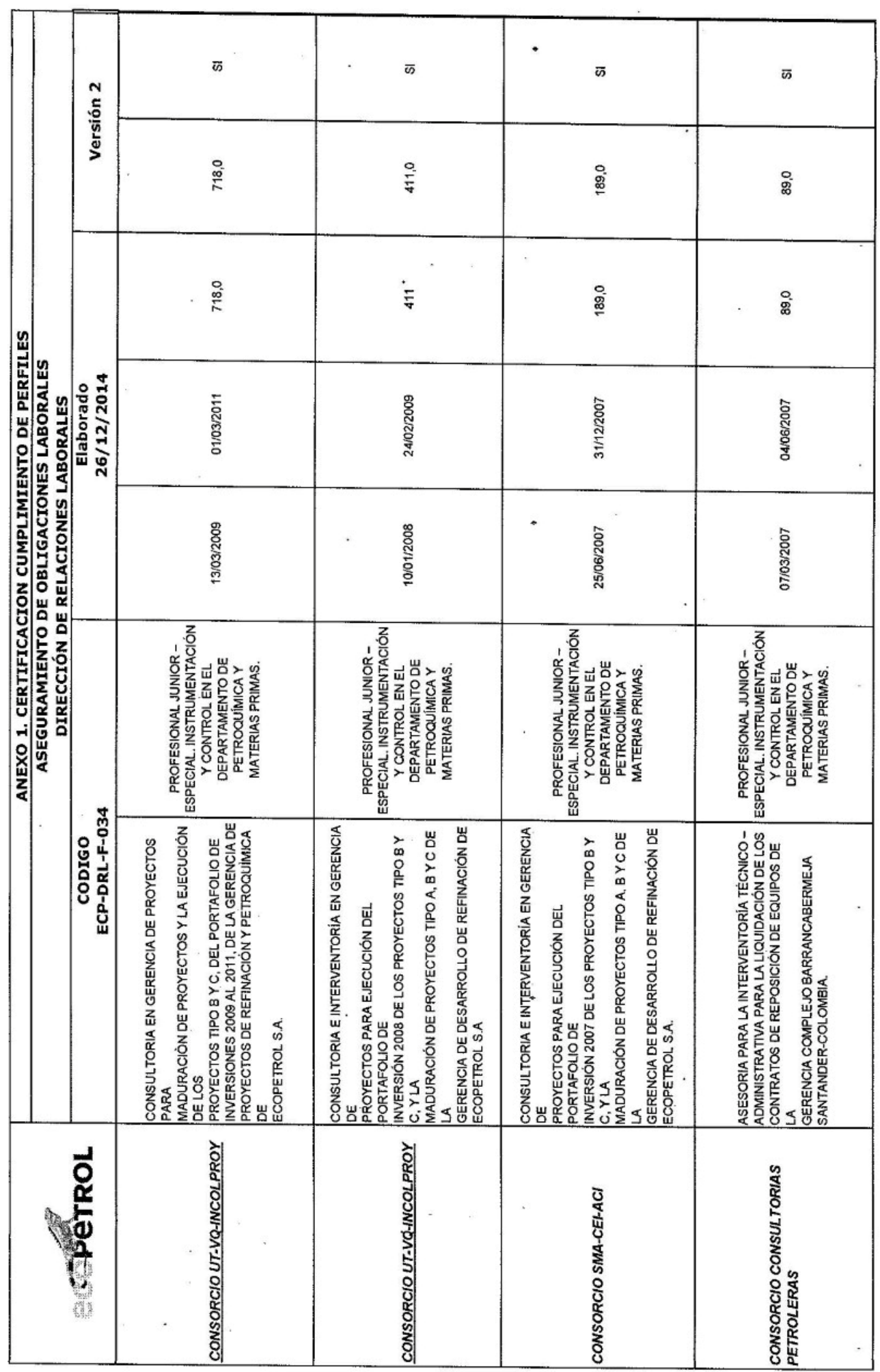




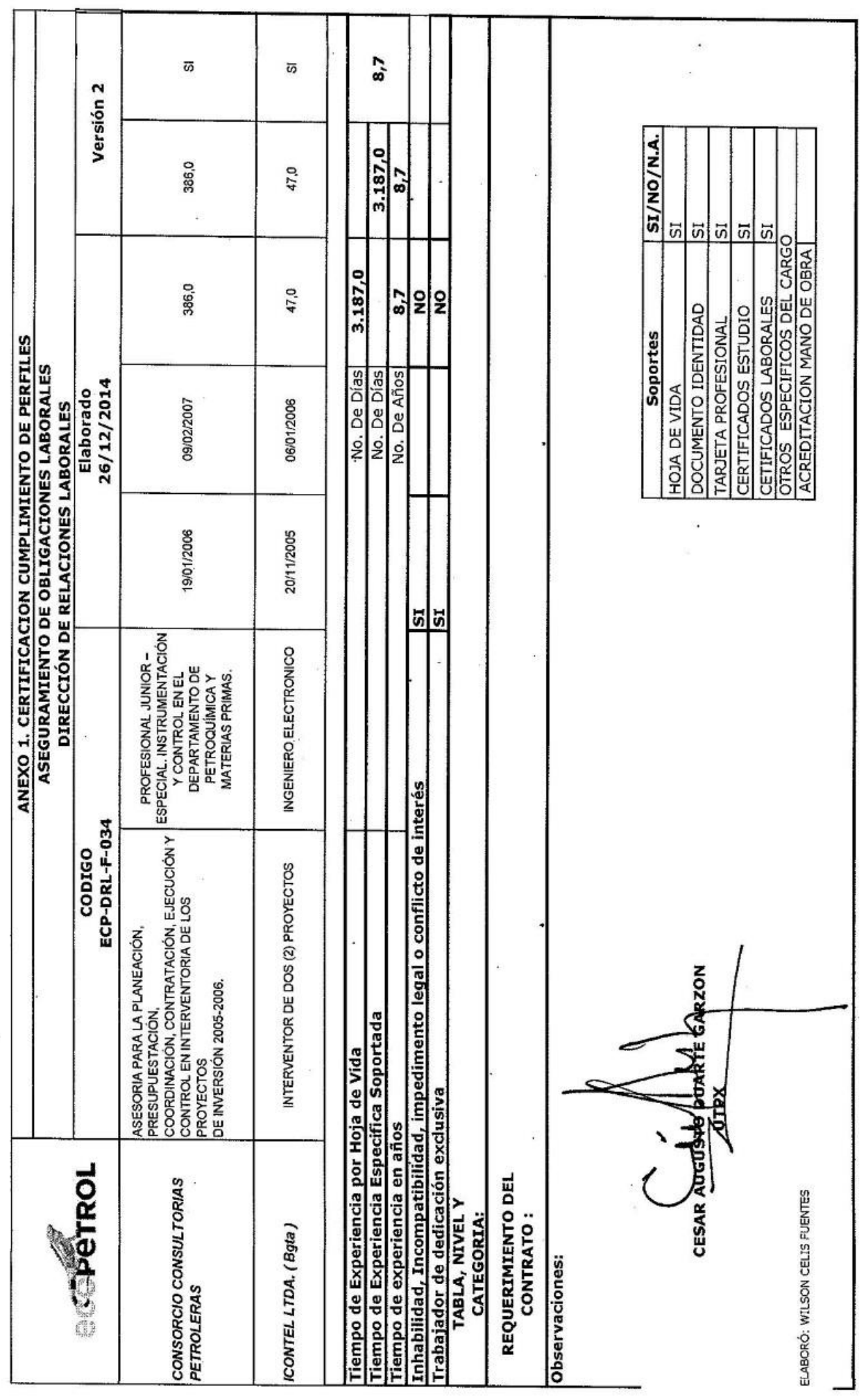

Figura 3. Certificación de cumplimiento de perfiles. 


\section{WILSON CELIS FUENTES}

\section{De: \\ Enviado el: \\ Para:}

Asunto: leonardo macias lozada <leonardo.macias.lozada@gmail.com>

lunes, 05 de enero de 2015 10:52 a. m

asistente.rrhh@dingenieria.com

Fwd: OT 4050964 CARGO INSTRUMENTISTA

Acepto las condiciones de Pago. Gracias

- Mensaje reenviado

De: leonardo macias lozada <leonardo.maciås.lozada@gmail.com>

Fecha: 3 de enero de 2015, 13:47

Asunto: Fwd: OT 4050964 CARGO INSTRUMENTISTA

Para: martinezamd78@gmail.com, Fredy Casadiego < $\underline{\text { administracion.tibu@dingenieria.com> }}$ >

$\mathrm{Si}$ acepto las condiciones y en la hora de la tarde envio todoa la documentación; porque estoy por fuera de la casa..gracias

- Mensaje reenviado

De: leonardo macias lozada <leonardo.macias.lozada@gmail.com>

Fecha: 3 de enero de 2015, 13:41

Asunțo: Re: OT 4050964 CARGO INSTRUMENTISTA

Para: Fredy Casadiego <administracion.tibu@dingenieria.com>

Buenas tardes si acepto el salariom y en el transcurso de la tarde les envio toda la documentacion. Gracias

Ing. Leonardo Macias

tf:3187073331

El 3 de enero de 2015, 11:49, Fredy Casadiego <

Buen día,

Leonardo, agradezco el interés por enviar hoja de vida para aplicar al cargo como Residente Instrumentista para el Municipio de Tibu, es un proyecto que tendrá en su momento una duración de dos a tres mes dependiendo del cronograma de actividades propuestas se continuara o simplemente se entenderá por terminado.

El salario pactado para este cargo es de $\$ 163.455$ diario, mensual de $\$ 4.903 .650$.

Realizando el Chek list cumple para el cargo solicitado, le agradezco me adjunte a su hoja de vida requisitos indispensables para una próxima contratación en caso de ser elegido.

Figura 4. Evidencia electrónica de aceptación de pago. 
So pretexto de ser una entidad de naturaleza estatal, ECOPETROL pacta cláusulas excepcionales o cláusulas exorbitantes (Ver Anexo B) establecidas en el estatuto general de la contratación estatal, a sabiendas de que la ley no le permite ni le faculta dicha posibilidad, posición evidenciada gracias al Consejo de Estado según la Sentencia del 20 de febrero de 2014, C.P. Ramiro Pazos Guerrero.

Considera que resulta inconveniente

Sala contenciosa administrativa, sección tercera,

4.4.2. Contrato MA-0020935 suscrito entre ECOPETROL S.A. y el CONSORCIO PLATAFORMAS PETROLERAS XIV cuyo objeto es "Obras civiles de realce y rehabilitación de los puntos críticos entre el K1+160 al K11+000 en el dique marginal que protege el municipio de Yondo (Antioquia), en el campo casabe de la gerencia regional magdalena medio de Ecopetrol S.A."•

4.4.2.1. Riesgos cubiertos bajo la retención en garantía y las garantías y seguros.

El contrato MA-0020935 establece en su cláusula 4 parágrafo primero:

Los valores en pesos colombianos retenidos por este concepto se entienden como saldos a favor del CONTRATISTA, los cuales serán depositados por ECOPETROL en una fiducia mercantil establecida por el CONTRATISTA en la entidad financiera que este indique, la cual debe estar debidamente aprobada por la Superintendencia Financiera. 
La administración y firma autorizada de la cuenta en mención, será exclusivamente de ECOPETROL a través del administrador del Contrato y su destino será únicamente el manejo de dineros provenientes de la Retención en Garantía. Esta cuenta será en pesos colombianos a nombre del Contrato y debe producir rendimientos financieros, los cuales serán entregados al CONTRATISTA cuando se liquide el patrimonio autónomo.

El contrato de fiducia mercantil que se constituya por parte del CONTRATISTA, deberá ser aprobado por el Gestor del Contrato y/o ECOPETROL, y en el mismo deberán incorporarse todas las observaciones de administración y manejo de recursos, según las previsiones establecidas en este Contrato y las que señale ECOPETROL.

Es obligación del CONTRATISTA acreditar dentro de los veinte (20) días hábiles siguientes a la firma del Contrato, la constitución de una fiducia mercantil, en la cual deberá constar expresamente que el CONTRATISTA cede de manera incondicional el valor total de las retenciones en garantía a favor de la sociedad fiduciaria (patrimonio autónomo). En el contrato de fiducia mercantil deberán ser incluidas todas las condiciones establecidas en este contrato aplicables y las particulares que exija ECOPETROL, sin que sea dable objeción alguna por parte del CONTRATISTA o la sociedad fiduciaria.

Todos los costos que demanden la constitución y administración del contrato de fiducia serán por cuenta del CONTRATISTA. El valor que conformará el patrimonio autónomo, no podrá ser entregado por la sociedad fiduciaria al CONTRATISTA, o a terceros por ECOPETROL, hasta tanto ECOPETROL de manera expresa lo 
autorice por escrito, previo el cumplimiento de los requisitos que se establecen para el pago final.

ECOPETROL podrá disponer libremente de los dineros que se depositen en el patrimonio autónomo para realizar pagos o atender obligaciones dinerarias a cargo del CONTRATISTA derivados de la ejecución del presente Contrato, conforme a las estipulaciones contenidas en este documento, por lo que en el contrato de fiducia mercantil deberán figurar como beneficiarios además del CONTRATISTA, ECOPETROL y terceros autorizados por ECOPETROL S.A. El CONTRATISTA con el presente Contrato conviene en autorizar a ECOPETROL para ordenar en cualquier momento a la sociedad fiduciaria, efectuar pagos directos a terceros (relacionados con obligaciones dinerarias a cargo del CONTRATISTA derivados de la ejecución del presente Contrato, y cuya condición de tercero vinculado al contrato haya sido avalado por el CONTRATISTA) con cargo a los recursos depositados en la fiducia mercantil.

Será obligación incondicional de la sociedad fiduciaria, devolver en cualquier momento y en forma inmediata a ECOPETROL los dineros que no se autoricen entregar al CONTRATISTA, una vez exista orden escrita para ello por parte de ECOPETROL.

Esta retención en garantía se da con el propósito de cubrir los riesgos relacionados a continuación y que se derivan de la ejecución del contrato:

a) No cumplimiento de obligaciones del Contratista emanadas del contrato

b) No pago de salarios, prestaciones sociales e indemnizaciones laborales. 
c) Mal manejo y cuidado de los bienes entregados por ECOPETROL.

d) Daños materiales, lesiones personales y/o muerte que se ocasionen a terceros.

A su vez, el contrato MA-0020935 en su página 12 - numeral 4 establece:

4 GARANTÍAS Y SEGUROS

El CONTRATISTA, dentro de los cinco (5) días hábiles siguientes a la suscripción de este Contrato, deberá constituir por su cuenta, ante una compañía de seguros legalmente autorizada para funcionar en Colombia, y entregar a ECOPETROL:

1) Una Garantía de Cumplimiento otorgada a favor de ECOPETROL S.A., que se rija por el Clausulado General de la Garantía Única de Cumplimiento anexo, y que contenga los siguientes amparos además de los exigidos en el clausulado General del Contrato, contenido en las CGC del PS :

a) De Cumplimiento de las obligaciones emanadas del Contrato, que garantice el cumplimiento de todas y cada una de las obligaciones a cargo del CONTRATISTA, el pago de la Cláusula de Descuentos como Apremio o Penalización y de la Cláusula Penal Pecuniaria, y que tenga:

- Un valor asegurado igual al $10 \%$ del valor estimado del Contrato , y 
- Una vigencia igual al término de vigencia del Contrato y un (1) mes más. Es decir: la vigencia de la póliza debe ser igual a la sumatoria del plazo de ejecución, más el plazo de liquidación de mutuo acuerdo, más un (1) mes.

b) De pago de salarios, prestaciones sociales e indemnizaciones laborales al personal vinculado para la ejecución del Contrato, que tenga:

- Un valor asegurado igual al 5\% del valor estimado del Contrato y

- Una vigencia igual al término de vigencia del Contrato y tres (3) años más. Es decir: la vigencia del amparo debe ser igual a la sumatoria del plazo de ejecución, más el plazo de liquidación de mutuo acuerdo, más tres (3) años.

c) De calidad de los servicios, que tenga:

- Un valor asegurado igual al 10\% del valor final del presente Contrato, y

- Una vigencia que comprenda el plazo de liquidación del Contrato de común acuerdo y un (1) año más, contada desde la fecha de terminación de este Contrato.

d) De estabilidad de la obra, que tenga:

- Un valor asegurado igual al $10 \%$ del valor estimado del presente Contrato, y

- Una vigencia de cinco (5) años contados a partir de la fecha de terminación de este Contrato. 
2) Adicionalmente y dentro del mismo término el CONTRATISTA deberá constituir y entregar a ECOPETROL los siguientes seguros:

a) Un seguro de Responsabilidad Civil Extracontractual que proteja a ECOPETROL frente a daños que puedan generarse a terceros dentro del desarrollo del Contrato y que incluya los amparos de contaminación, contratistas y subcontratistas, cruzada, propiedades adyacentes, bienes bajo cuidado, tenencia y control, vehículos propios y no propios y equipos mecánicos. Por un valor asegurado, equivalente al diez por ciento (10\%) del valor estimado del presente Contrato, con una vigencia igual a la del Contrato. ECOPETROL debe figurar como asegurado y beneficiario adicional.

Al igual en el contrato MA-0018531, estableciendo un paralelo entre la CLÁUSULA 4 PARÁGRAFO PRIMERO y la PÁGINA 12 - NUMERAL 4 se evidencia la vulneración del principio de la buena fe con el excesivo cubrimiento de obligaciones tales como; i) el cumplimiento de obligaciones del Contratista emanadas del contrato; ii) pago de salarios, prestaciones sociales e indemnizaciones laborales; iii) Buen manejo y cuidado de los bienes entregados por ECOPETROL; iv) Daños materiales, lesiones personales y/o muerte que se ocasionen a terceros; toda vez que los riesgos cubiertos por la garantías y seguros se vuelven a cubrir los montos retenidos como retegarantía en la forma indicada en la CLÁUSULA 4 PARÁGRAFO PRIMERO.

\subsubsection{Eventos contractuales del contrato MA-0020935.}

i) El 11 de enero de 2013 se suscribió el contrato MA-0020935 con un plazo de ejecución de 150 días calendario y un plazo de liquidación de 4 meses. 
ii) El 7 de marzo de 2013 se suscribió el acta de inicio del contrato con fecha de inicio del contrato del 11 de marzo de 2013 y un plazo de ejecución de 150 días calendario, es decir hasta el día 11 de agosto de 2013.

iii) El 6 de agosto de 2013 se suscribió el otrosí No. 1, con el objeto de ampliar el plazo de ejecución del contrato en 30 días calendario, quedado como nueva fecha de terminación el 10 de septiembre de 2013.

iv) El 05 de septiembre de 2013, se suscribió el otrosí No. 2, con el objeto de ampliar el plazo de ejecución del contrato en 18 días calendario, quedando como nueva fecha de terminación el 28 de septiembre de 2013.

v) El 28 de septiembre de 2013, se suscribió el otrosí No. 3, con el objeto de ampliar el plazo de ejecución del contrato en 30 días calendario, quedando como nueva fecha de terminación el 28 de octubre de 2013.

vi) El 25 de octubre de 2013, se suscribió el otrosí No. 4, con el objeto de ampliar el plazo de ejecución del contrato en 30 días calendario, quedado como nueva fecha de terminación el 27 de noviembre de 2013.

\subsubsection{El abuso del derecho y el desconocimiento de la buena fe en el contrato MA- 0020935 incrementa los costos de transacción reduciendo así la utilidad del contratista.}

Al igual que en el caso del contrato MA-0018531, en el contrato MA-0020935 se evidencia como la desconfianza por parte de ECOPETROL S.A. hacia el CONTRATISTA incrementa ineficientemente la cantidad de términos explícitos a considerar por las partes, resaltándose nuevamente la constitución de un contrato de fiducia mercantil para el recaudo de una retegarantia y la constitución de una garantía de cumplimiento otorgada a favor de ECOPETROL S.A., ambas con el fin de cubrir los riesgos por i) cumplimiento de obligaciones del Contratista emanadas del contrato; ii) pago de salarios, prestaciones sociales e indemnizaciones laborales; iii) Buen manejo y cuidado de los bienes entregados por 
ECOPETROL; iv) Daños materiales, lesiones personales y/o muerte que se ocasionen a terceros, distinguiéndose las ampliaciones de los plazos contractuales en los cuales el contratista incurre en sobrecostos por motivo de prórrogas de pólizas y mayor tiempo de administración del contrato de fiducia.

\subsubsection{Otros casos en los que se constata el abuso del derecho y violación del principio} de la buena fe reduciendo la utilidad del contratista.

A continuación se relacionan 4 casos donde al igual que en los dos casos anteriores se evidencia la vulneración del principio de la buena fe con el excesivo cubrimiento de obligaciones mediante la constitución de un contrato de fiducia mercantil y la constitución de pólizas de cumplimiento incluyéndose dentro de los costos del contratista las prórrogas de las mismas, demostrándose así una tendencia en los contratos de Ecopetrol.

1. Contrato MA-0019649 suscrito entre UNIÓN TEMPORAL PLATAFORMAS PETROLERAS X y ECOPETROL S.A. cuyo objeto es CONTRATO MARCO PARA MONTAJE Y CONSTRUCCIÓN DE FACILIDADES DE SUPERFICIE PARA PROYECTOS DE PRODUCCIÓN Y EXPLORACIÓN A NIVEL NACIONAL Y CAMPOS MENORES ASOCIADOS A LA GERENCIA, PARA LA VEX.

2. Contrato MA-0011855 suscrito entre el CONSORCIO LOCACIONES D\&D y ECOPETROL S.A. cuyo objeto es OBRAS CIVILES, ADECUACIÓN Y MANTENIMIENTO DE UNA (1) LOCACIÓN PARA POZOS, ESTACIONES PETROLERAS Y VÍAS DE ACCESO, CON USO DE OPCIÓN DE OTRAS TRES (3) LOCACIONES PARA OBRAS CIVILES DE CONSTRUCCIÓN, ADECUACIÓN Y MANTENIMIENTO DE POZOS Y ESTACIONES PETROLERAS Y VÍAS DE ACCESO, PARA EL PROGRAMA DE HIDROCARBUROS DE YACIMIENTOS NO CONVENCIONALES DE ECOPETROL S.A.

3. Contrato MA-0006403 suscrito entre D. INGENIERIA LTDA., y ECOPETROL S.A. cuyo objeto es "OBRAS CIVILES Y ADECUACIONES ARQUITECTÓNICAS PARA LA ESTACIÓN J-25 DEL CAMPO TIBÚ, PERTENECIENTE A LA GERENCIA CATATUMBO ORINOQUÍA DE ECOPETROL S.A.” 
4. Contrato No. 5206394 suscrito entre el CONSORCIO MAGDALENA MEDIO y ECOPETROL S.A. cuyo objeto es OBRAS DE CONSTRUCCIÓN PARA LA RECUPERACIÓN AMBIENTAL Y OBRAS ADICIONALES DE CATORCE (14) POZOS DE DESARROLLO EN LA VIGENCIA 2009 Y VEINTITRÉS (23) OPCIONALES VIGENCIA 2010 EN LOS CAMPOS CANTAGALLO, YARIGUIES Y GARZAS DE LA SUPERINTENDENCIA DE OPERACIONES DEL RIO DE LA GERENCIA REGIONAL MAGDALENA MEDIO DE ECOPETROL S.A.

Ecopetrol S.A. reduce la utilidad del contratista al momento de no liquidar el contrato de forma puntualmente establecida en el mismo, toda vez que lo anterior ocasiona que este tiempo muerto e incierto para el contratista se convierte en meses o años a la espera de que Ecopetrol S.A liquide, lo que a todas luces vislumbra como abuso del derecho, posición dominante y violación al principio de la buena fe. Este tiempo muerto para el contratista ocasiona daño económico, detrimento patrimonial, disminución en la utilidad que el contrato pueda tener para el contratista porque él mismo debe incurrir en extender por el tiempo que Ecopetrol S.A. a bien tenga, toda las pólizas exigidas por el mismo, como se mencionó anteriormente: Garantía de Cumplimiento otorgada a favor de ECOPETROL S.A, Garantía de Cumplimiento de las obligaciones emanadas del Contrato, Garantía de pago de salarios, Garantía de prestaciones sociales e indemnizaciones laborales al personal vinculado para la ejecución del Contrato, Garantía de calidad de los servicios, Garantía de estabilidad de la obra, seguro de Responsabilidad Civil Extracontractual que proteja a ECOPETROL frente a daños que puedan generarse a terceros, entre otros.

\subsection{Sobre las cláusulas excepcionales o exorbitantes previstas en el Estatuto}

\section{General de Contratación Estatal, y su aplicación en los contratos sometidos a las}

\section{reglas de derecho privado en los que haga parte una entidad estatal}

Las cláusulas exorbitantes o excepcionales son estipulaciones que confieren derechos u obligaciones que en el marco de las leyes comunes o comerciales no podrían ser consentidas libremente por el desequilibrio o desigualdad que podrían generar en las relaciones contractuales, en las cuales, en principio, prima el estado de igualdad y la autonomía de la 
voluntad de las partes. Estas cláusulas o poderes excepcionales suponen que una de las partes en la relación contractual se ponga en una posición más privilegiada o dominante, ya que al ser ajenas a los principios de libertad contractual, igualdad y autonomía de la voluntad, resultan convirtiéndose en imposiciones que no son objeto de negociación o acuerdo voluntario entre las partes.

Debido a que las cláusulas o poderes excepcionales o exorbitantes suponen una imposición y el quebrantamiento de la igualdad entre las partes contratantes, su fuerza vinculante no encuentra su sustento en el acuerdo voluntario que constituye ley para las partes $^{1}$, como sucede en los contratos sometidos estrictamente al derecho común, sino que proviene de la ley o de una norma superior que autoriza y confiere esa facultad a un sujeto determinado bajo el cumplimiento de ciertos requisitos previamente definidos ${ }^{2}$.

En el ordenamiento jurídico colombiano se encuentra que el Estatuto General de la Contratación Estatal -Ley 80 de 1993, modificada por la Ley 1150 de 2007- estableció que únicamente las entidades públicas sometidas en su actividad contractual a sus disposiciones pueden pactar a su favor, bajo el cumplimiento de ciertos requisitos, las cláusulas excepcionales al derecho común de terminación, interpretación y modificación unilaterales, de sometimiento a las leyes nacionales, de caducidad, de reversión ${ }^{3}$ y de imposición unilateral

\footnotetext{
${ }^{1}$ Artículo 1602 del Código Civil. Los contratos son ley para las partes. Todo contrato legalmente celebrado es una ley para los contratantes, y no puede ser invalidado sino por su consentimiento mutuo o por causas legales.

2 "La exorbitancia entonces, dentro del contexto analizado, proviene de la ley y no de la voluntad de los implicados, pues el imperio de una de las partes, acompañado de jurisdicción, competencia y decisión previa obligatoria sobre la otra, no puede provenir de la autonomía de un pacto, sino de expresa habilitación legal." PALACIO JARAMILlO, María Teresa. Revista de Derecho Público n. ${ }^{\circ}$ 17. Aspectos controversiales de la contratación estatal. Cláusulas excepcionales. Bogotá, Uniandes, 2004, p. 104.

${ }^{3}$ Artículo 14. De los medios que pueden utilizar las entidades estatales para el cumplimiento del objeto contractual. Para el cumplimiento de los fines de la contratación, las entidades estatales al celebrar un contrato: (...)

2o. Pactarán las cláusulas excepcionales al derecho común de terminación, interpretación y modificación unilaterales, de sometimiento a las leyes nacionales y de caducidad en los contratos que tengan por objeto el
} 
de multas ${ }^{4}$, determinación que excluye de entrada el pacto de cláusulas excepcionales en contratos celebrados entre particulares o en contratos que no se encuentren sometidos a las reglas establecidas en el Estatuto General de Contratación Estatal.

Como se puede observar, estas cláusulas poseen la característica esencial de que pueden ser ejecutadas de manera unilateral por la entidad que las pactó a su favor, lo que significa que no deben acudir a instancias judiciales para obtener el cumplimiento de la obligada ni deben contar con la aprobación de la otra parte contratante, potestad de ejecución que, en principio, en el ámbito del derecho privado se encuentra proscrita por estar reservada exclusivamente para las entidades estatales, motivo adicional para afirmar que las cláusulas

ejercicio de una actividad que constituya monopolio estatal, la prestación de servicios públicos o la explotación y concesión de bienes del Estado, así como en los contratos de obra. En los contratos de explotación y concesión de bienes del Estado se incluirá la cláusula de reversión.

Las entidades estatales podrán pactar estas cláusulas en los contratos de suministro y de prestación de servicios.

En los casos previstos en este numeral, las cláusulas excepcionales se entienden pactadas aún cuando no se consignen expresamente. $(\ldots)$

${ }^{4}$ De conformidad con lo establecido en el parágrafo del artículo 17 de la Ley 1150 de 2007, la cláusula penal y las multas podrán hacerse efectivas de manera unilateral por las entidades estatales. Esta norma señala: Artículo 17. Del derecho al debido proceso. El debido proceso será un principio rector en materia sancionatoria de las actuaciones contractuales.

En desarrollo de lo anterior y del deber de control y vigilancia sobre los contratos que corresponde a las entidades sometidas al Estatuto General de Contratación de la Administración Pública, tendrán la facultad de imponer las multas que hayan sido pactadas con el objeto de conminar al contratista a cumplir con sus obligaciones. Esta decisión deberá estar precedida de audiencia del afectado que deberá tener un procedimiento mínimo que garantice el derecho al debido proceso del contratista y procede sólo mientras se halle pendiente la ejecución de las obligaciones a cargo del contratista. Así mismo podrán declarar el incumplimiento con el propósito de hacer efectiva la cláusula penal pecuniaria incluida en el contrato.

Parágrafo. La cláusula penal y las multas así impuestas, se harán efectivas directamente por las entidades estatales, pudiendo acudir para el efecto entre otros a los mecanismos de compensación de las sumas adeudadas al contratista, cobro de la garantía, o a cualquier otro medio para obtener el pago, incluyendo el de la jurisdicción coactiva. 
exorbitantes serían inoperantes en las relaciones contractuales de índole privado en las que no exista habilitación legal ${ }^{5}$.

De igual manera, un amplio sector de la doctrina ${ }^{6}$ también ha respaldado la posición consistente en que en las relaciones contractuales sometidas al derecho privado no es conveniente pactar o ejercer potestades de naturaleza exorbitante, ya que además de suponer su inclusión un desequilibrio y limitación a la autonomía contractual de las partes, su habilitación en el ámbito privado podría conllevar al ejercicio arbitrario o abusivo de las cláusulas por la posición preferencial de una de las partes en el contrato, circunstancias que en últimas desconocerían la finalidad de su consagración legal para la contratación de las entidades públicas, la cual no es otra sino obtener la protección del patrimonio público y hacer prevalecer el interés general sobre el particular.

Así las cosas, resulta claro que el cumplimiento o ejercicio de las cláusulas excepcionales o exorbitantes fue una potestad que se reservó el Estado para su actividad contractual, y que frente a la actividad contractual sometida al derecho común, en principio, esas prerrogativas o potestades no se encuentran habilitadas por una ley o norma superior.

Ahora, en cuanto a la estipulación de cláusulas excepcionales o exorbitantes en contratos sometidos a reglas de derecho privado en los que haga parte una entidad estatal, soportada en la Sentencia 2010-00262 de febrero 20 de 2014, esta Corporación ha sostenido

\footnotetext{
${ }^{5}$ Como ejemplo de habilitación legal a los particulares para ejercer una potestad exorbitante se encuentra la facultad del mandante de dar por terminado de manera unilateral el contrato de mandato en ciertos eventos, potestad que se encuentra consagrada en el artículo 2191 del Código Civil de la siguiente manera: El mandante puede revocar el mandato a su arbitrio, y la revocación expresa o tácita, produce su efecto desde el día que el mandatario ha tenido conocimiento de ella.

${ }^{6}$ Al respecto ver: PALACIO JARAMILLO, María Teresa. Op. cit., p. 103, y PALACIO HINCAPIÉ, Juan Ángel. La contratación de las entidades estatales. Bogotá, Librería Jurídica Sánchez R. Ltda, 6a ed., 2010, p. 374 a 375 .
} 
que como en aquellos casos las entidades estatales actúan por disposición de la ley en igualdad de condiciones con los particulares, no es posible que se incluyan o ejerzan las potestades excepcionales o exorbitantes previstas en las normas públicas que rigen la contratación estatal, pues tales potestades no se encuentran atribuidas o autorizadas en las normas civiles o comerciales, y su habilitación en ningún caso puede provenir de la autonomía de la voluntad de las partes o por extensión de las normas de contratación estatal.

Así las cosas, si el Estatuto General de la Contratación Estatal -Ley 80 de 1993, modificada por la Ley 1150 de 2007- no contempló la posibilidad de que las entidades públicas sometidas a sus disposiciones pudieran cobrar unilateralmente las multas pactadas, mal haría en considerarse que los particulares o las entidades públicas sometidas a las normas de derecho común en su actividad contractual sí se encuentran facultadas para hacerlo, pues de igual forma carecerían de sustento legal para ello.

De acuerdo con los anteriores argumentos y gracias al Consejo de Estado según la Sentencia del 20 de febrero de 2014, C.P. Ramiro Pazos Guerrero, es posible llegar a las siguientes conclusiones relevantes: i) que las entidades públicas sometidas en su actividad contractual a las reglas de derecho común no pueden pactar las cláusulas excepcionales o exorbitantes previstas en el Estatuto General de Contratación Estatal, salvo que la ley o una norma superior lo autorice de manera clara y expresa, y ii) que la ejecución o cumplimiento unilateral de una cláusula excepcional o exorbitante en los contratos sometidos al derecho común es ilegal por comportar una potestad exclusiva del Estado, salvo que se ejerza bajo el amparo de una ley o norma superior”.

Se observa como Ecopetrol está aplicando inadecuadamente el principio de la autonomía de la voluntad privada, quebrantando con ello la buena fe del contratista, al 
imponerle cláusulas fuera de las permitidas por la normatividad privada y queriendo usar la normatividad dirigida para las contrataciones públicas a su favor, desconociendo desde su naturaleza jurídica como sociedad de economía mixta hasta los mismos principios de la función pública, a los que sí está sometido.

Lo importante es que el contratista puede acudir a la administración de justicia para hacer valer sus derechos y no dejar que la arbitrariedad del contratante, disfrazada de autonomía de la voluntad, quebrante normas constitucionales, legales y principios que son base en nuestro Estado Social de Derecho.

\subsection{Reflexión final}

Se puede hablar de acto abusivo o abuso del derecho cuando alguien ejercita su derecho de un modo inadmisible, en cuanto perjudica a terceros, desconociendo así principios y valores constitucionales, lo que le acarrea asumir las consecuencias de su ejercicio abusivo. Ejercitar un derecho de manera inadmisible, a pesar de que la ley no lo impida expresamente, puede ser entendido como un comportamiento -social, política y filosóficamente- reprochable, en la medida en que las teorías modernas de la justicia, sin perjuicio de sus diferencias, defienden la idea de que todas las personas merecen respeto. Por lo tanto y en aras de asegurar la vigencia de un orden justo, es deseable que intervengan las autoridades competentes en aquellos escenarios en los que se advierta el ejercicio abusivo de un derecho. En materia contractual,. por ejemplo, puede configurarse el abuso del derecho si se dan los siguientes presupuestos (Hernández Velasco \& Pardo Martínez, 2014):

- La existencia de un contrato. 
- El abuso de la posición dominante: son agentes con posición dominante quienes tienen un lugar de privilegio en el tráfico de capitales o en la prestación de bienes o servicios, o quienes se dedican a la contratación masiva y estandarizada.

\section{- El perjuicio.}

- La relación de causalidad entre el perjuicio y la conducta abusiva.

Vale agregar que el abuso del derecho también puede darse en los actos preparatorios, en la formación del contrato, en su ejecución, en su disolución e incluso en el período postcontractual. Así lo recuerdan los profesores Héctor Elías Hernández Velasco y Orlando Pardo Martínez, quienes afirman:

En resumidas cuentas, en materia de los actos jurídicos contractuales bien puede llegarse a configurar el abuso del derecho en cualquier tipo contractual, ya sea en los actos preparatorios, de ejecución o incluso en los actos poscontractuales; ello, toda vez que se den los elementos [atrás referidos] que la Corte Suprema ha dejado establecidos para su configuración, como se dio desde sus primeros fallos en 1899 y en los que, posterior a 1935 y hasta la fecha, ha venido profiriendo en la materia y reforzando a partir de la expedición de la Constitución de 1991; en ella, como queda visto, el abuso del derecho hace parte de los principios constitucionales; de este hecho se infiere que en un Estado social de derecho, como el colombiano, a los individuos se les reconoce la posibilidad de obrar de acuerdo con su voluntad, siempre y cuando respeten el orden jurídico y los derechos de las demás personas, so pena de tener la obligación de resarcir los perjuicios que con la actuación se cause. 
En este orden de ideas, como Ecopetrol -agente con posición dominante que funge como contratante- exige que sea constituida a su favor y a costa del contratista la garantía única de cumplimiento, la cual se rige por un determinado clausulado general y ampara ciertos riesgos de suyo impertinentes en la medida en que, en relación con algunos de estos, no le asiste interés directo en su calidad de contratante. Y como con aquella exigencia fundada en criterios ilógicos de desconfianza- que hace Ecopetrol al contratista se causa un perjuicio de índole patrimonial a este último, dado que es a quien le corresponde pagar la prima al asegurador, hay lugar a declarar la responsabilidad civil del contratante por su conducta abusiva o abuso del derecho, en aras de hacer respetar el artículo 95 constitucional, a cuyo tenor todas las personas y ciudadanos deben "respetar los derechos ajenos y no abusar de los propios". Precepto este que obliga a abandonar ideas individualistas del Estado Liberal, según las cuales "quien su derecho ejerce, a nadie ofende", aforismo que incentivó -por muchos años- el ejercicio desmedido y desproporcionado de los derechos. Se rescata, entonces, el pensamiento de los hermanos Mazeaud, en el sentido de que "los derechos no han sido conferidos para que se ejerzan con un fin puramente egoísta, sin tener en cuenta el influjo que pueda tener su ejercicio sobre nuestros semejantes, y que el interés social debe tener un sitio junto al interés individual del titular del derecho ejercido" 7 .

Sin duda, se abusa del derecho cuando es desconocido el principio de la buena fe y es desconocido este principio cuando Ecopetrol, fundado en criterios desacertados de desconfianza, exige una póliza de seguro con base en riesgos que no lo acechan en sana lógica, pues el pago de salarios, prestaciones sociales e indemnizaciones laborales -a quienes son vinculados para la ejecución del contrato- es un asunto exclusivo entre el contratista y sus

\footnotetext{
7 Hermanos Mazeaud, citado por Corte Suprema de Justicia, Cas. Civ., sentencia del 11 de octubre de 1973, proceso de Luis Enrique Páez Sierra contra la Caja de Crédito Agrario, Industrial y Minero.
} 
trabajadores, respecto al cual Ecopetrol no debe inmiscuirse. De igual forma, resulta abusivo y contrario a la buena fe que el cambio o sustitución del personal vinculado para la ejecución del contrato deba ser autorizado previamente por Ecopetrol y que esta empresa, además, se arrogue el derecho de ser la única en determinar la idoneidad del personal del contratista, como si este no supiera seleccionar su propio personal. Esto último, en particular, comporta un trato desatinado, abusivo e insensato al contratista, en la medida en que se le hace ver que no tiene las competencias y aptitudes para escoger sus trabajadores.

El Estado, por mandato del artículo 333 de la Constitución el cual reza “...debe evitar y controlar cualquier abuso que personas o empresas hagan de su posición dominante en el mercado nacional" , da a concluir que si Ecopetrol -agente con posición dominante en el mercado- abusa del derecho en el marco de sus relaciones contractuales, debe activarse el control estatal, a través de la aplicación de las normas que regulan la responsabilidad civil contractual, lo que garantizaría la eficacia de la buena fe como principio constitucional, incluso desde la etapa precontractual. Esto -en términos de Robert Alexy- implica reconocer que aquel principio es una verdadera norma jurídica que vincula y obliga a Ecopetrol, a pesar de su posición dominante en el mercado, razón que forza a esta empresa a resarcir los perjuicios -patrimoniales y extrapatrimoniales- que cause por desconocerlo en el marco de sus relaciones contractuales.

Es probable que si Ecopetrol reflexiona sobre la importancia de respetar el principio de la buena fe en el marco de todas sus relaciones contractuales, no sea necesario insistir en el punto de la responsabilidad civil, pues esta empresa acogerá una visión más acorde con la actual cultura constitucional del país que le permitirá brindarle al contratista un trato más razonable, justo y equilibrado, sin desconfianzas infundadas. En otras palabras, es un cambio de mentalidad el que se sugiere respetuosamente a Ecopetrol, a través de este documento 
académico, con el fin de que sea garantizada la eficacia de la Constitución Política en sus relaciones con los particulares, al estilo de la doctrina denominada Drittwirkung der Grundrechte (Estrada, 2000).

\section{Conclusiones}

El principio de la buena fe tiene su sustento en la Constitución Política de Colombia, en el artículo 83, que establece que las actuaciones de los particulares y de las autoridades públicas deben ceñirse a la buena fe, la cual, según la jurisprudencia constitucional, se entiende como un imperativo de honestidad, confianza, rectitud, decoro y credibilidad que acompaña la palabra comprometida, se presume en todas las actuaciones y se erige en pilar fundamental del sistema jurídico. Y que se constituye en un límite a la actuación estatal y de los particulares.

$>\quad$ En el ámbito de las relaciones contractuales, el principio de la buena fe juega un papel señalado no solo en el campo del ejercicio de los derechos y potestades, sino en el de la constitución de las relaciones y en el cumplimiento de los deberes; admite la necesidad de una conducta leal, honesta; aquella conducta que, según la estimación de la gente, puede esperarse de una persona.

$>\quad$ El principio de buena fe tiene, entre otras, dos manifestaciones concretas, las cuales son: el respeto por el acto propio y la confianza legítima que, conjuntamente, previenen a los operadores jurídicos de contravenir o ir en contra de sus actuaciones precedentes y de defraudar las expectativas que generan en los demás, a la vez que compelen a las autoridades y a los particulares a conservar una coherencia en sus actuaciones, un respeto por los 
compromisos adquiridos y una garantía de estabilidad y durabilidad de las situaciones que objetivamente permitan esperar el cumplimiento de las reglas propias del tráfico jurídico.

$>\quad$ Si partimos de la raíz del mandato legal, el contrato es ley para las partes. PACTA SUN SERVANDA. Unilateralmente no se pueden alterar los términos del contrato, por regla general cualquier modificación del contrato debe estar sometida al concurso de voluntades y consentimiento expreso de las partes. Es de resaltar que para el caso que nos ocupa exactamente con Ecopetrol S.A, el mismo no genera dinámica de negociación con el contratista en razón a que no incluye su voluntad, en mejor expresión, la ignora. Es palpable la posición dominante de Ecopetrol y su abuso frente al contratista en razón a que da a la autonomía privada un alcance que no tiene, adoptando incluso clausulas exorbitantes y exigiendo un excesivo cubrimiento de riesgos a través de garantías y seguros, en algunas ocasiones, innecesarios.

$>\quad$ Se abusa del derecho cuando es desconocido el principio de la buena fe y es desconocido este principio cuando Ecopetrol, fundado en criterios desacertados de desconfianza, exige una póliza de seguro con base en riesgos que no lo acechan en sana lógica, pues el pago de salarios, prestaciones sociales e indemnizaciones laborales -a quienes son vinculados para la ejecución del contrato- es un asunto exclusivo entre el contratista y sus trabajadores, respecto al cual Ecopetrol no debería inmiscuirse si realmente concibiera el principio de la buena fe como se desarrolla en este trabajo. De igual forma, resulta abusivo y contrario a la buena fe que el cambio o sustitución del personal vinculado para la ejecución del contrato deba ser autorizado previamente por Ecopetrol y que esta empresa, además, se arrogue el derecho de ser la única en determinar la idoneidad del personal del contratista, como si este no supiera seleccionar su propio personal. Esto último, en particular, comporta un trato desatinado, abusivo e insensato al contratista, en la medida en que se le hace ver que no tiene las competencias y aptitudes para escoger sus trabajadores. 
Ecopetrol -agente con posición dominante que funge como contratante- exige que sea constituida a su favor y a costa del contratista la garantía única de cumplimiento, la cual se rige por un determinado clausulado general y ampara ciertos riesgos que, en gracia de discusión y si se concibiera el principio de la buena fe en los términos de esta investigación, resultan innecesarios. Y como con aquella exigencia -fundada en criterios excesivos de desconfianza- que hace Ecopetrol al contratista se causa un perjuicio a este último, dado que es a quien en principio le corresponde pagar la prima al asegurador $\mathrm{y}$, en caso de no contar en ese momento con los recursos para hacerlo, puede perder una oportunidad importante en cuanto esto le impediría cumplir con los requisitos y obligaciones a su cargo, sufriendo entonces un perjuicio que podría denominarse pérdida del chance o de oportunidad. Por tanto, hay lugar a declarar la responsabilidad civil del contratante por su conducta abusiva o abuso del derecho, en aras de hacer respetar el artículo 95 constitucional, a cuyo tenor todas las personas y ciudadanos deben "[r]espetar los derechos ajenos y no abusar de los propios".

El Estado, por mandato del artículo 333 de la Constitución, debe evitar y controlar cualquier abuso que personas o empresas hagan de su posición dominante en el mercado nacional, lo que significa que si Ecopetrol -agente con posición dominante en el mercadoabusa del derecho en el marco de sus relaciones contractuales, debe activarse el control estatal, a través de la aplicación de las normas que regulan la responsabilidad civil contractual, lo que garantizaría la eficacia de la buena fe como principio constitucional, incluso desde la etapa precontractual. Esto -en términos de Robert Alexy-implica reconocer que aquel principio es una verdadera norma jurídica que vincula y obliga a Ecopetrol, a pesar de su posición dominante en el mercado, razón que forza a esta empresa a resarcir los perjuicios -patrimoniales y extrapatrimoniales- que cause por desconocerlo en el marco de sus relaciones contractuales. 


\section{Bibliografía}

Borda, A. (1993). La teoría de los actos propios (Segunda edición ed.). Buenos Aires: Buenos Aires: Abeledo-Perrot.

Mesa Valencia, A. F. (2013). El principio de la buena fe, el acto propio y la confianza legítima. Hacia una teoría del precedente administrativo en Colombia. Universidad de Antioquia, Facultad de Derecho y Ciencias Políticas.

Ordoqui Castilla, G. (2011). Buena fe en los contratos. Editorial Reus.

Neme Villareal, M. L. (2009). Buena fe subjetiva y buena fe objetiva. Equívocos a los que conduce la falta de claridad en la distinción de tales conceptos. Revista de Derecho Privado (17), 45-76.

Caicedo Medrano, A. S. (2009). El principio de confianza legítima en las sentencias de la Jurisdicción Contencioso Administrativa y su incidencia en la congestión de los despachos judiciales en Colombia. Revista Diálogos de Derecho y Política (1).

Castillo Blanco, F. (1998). La protección de la confianza en el Derecho Administrativo. Madrid: Marcial Pons. 
Bernal Fandino, M. (2008). El deber de coherencia en los contratos y la regla del venire contra factum proprium. International Law: Revista Colombiana de Derecho Internacional , 291-321.

Bianchi, E., \& Iribarne, H. El principio general de la buena fe, y la doctrina del 'venire contra factum proprium non valet. Revista El Derecho , 108, 851-862.

Largo Taborda, A. (2012). Tensión entre autonomía y la buena fe en la contratación privada contemporánea. Medellín: Universidad de Antioquia, Facultad de Derecho y Ciencias Políticas.

Corral Talciani, H. (2010). Venire contra factum proprium. Escritos sobre la fundamentación, alcance y límites de la doctrina de los actos propios. Cuadernos de Extensión (18), 19-33.

Cortés, J. (2008). Cambio regulatorio y seguridad jurídica, breves notas sobre el principio de confianza legítima. Berkley Program in Law and Economics Annual Papers .

Díez Picazo, L. (1963). La doctrina de los propios actos: un estudio crítico sobre la jurisprudencia del tribunal supremo. Bosch.

Ekdahl Escobar, M. F. (1989). La doctrina de los actos propios: el deber jurídico de no contrariar conductas propias pasadas. Editorial Jurídica de Chile.

Esguerra Protocarrero, J. C. (2004). La protección constitucional del ciudadano. LEGIS.

Fortes Martín, A. (2006). Estudio sobre la revocación de los actos administrativos. Revista de Derecho , XIX (1), 149-177.

Fueyo Laneri, F. (1990). Instituciones de derecho civil moderno. Chile: Editorial Jurídica de Chile.

García De Enterría, E. (1956). La doctrina de los actos propios y el sistema de la lesividad. Revista de Administración Pública, 20.

García de Enterría, E., \& Fernández Rodríguez, T.-R. (2011). Curso de Derecho administrativo I (Vol. 1). S.L. CIVITAS EDICIONES. 
González Pérez, J. (2009). El principio general de la buena fe en el derecho. S.L. CIVITAS EDICIONES.

De los Mozos, J. L. (1965). El Principio de la buena fe. Sus aplicaciones prácticas en el derecho civil español. Barcelona: Bosch Casa Editorial.

Suarez, G. (2009 ). La nueva contratación pública en Colombia. Bogotá: LEGIS.

Corte Constitucional . (Abril de 1992). Sentencia C-543 MP[José Gregorio Hernández].

Corte Constitucional . (Abril de 1996). Sentencia C-154 MP[Antonio Barrera Carbonell].

Consejo de Estado Sección Tercera. (11 de Septiembre de 1989). Sentencia Exp. 5334 MP[Gustavo De Greiff Restrepo].

Consejo de Estado Sección Tercera. (14 de Marzo de 2013). Sentencia Radicado № 19960357701 MP [Alberto Zambrano Barrera].

Consejo de Estado, Sección Tercera. (6 de Mayo de 1992). Sentencia Exp. 5931 MP[Carlos Alberto Betancourt].

Consejo de Estado, Sección Tercera. (1 de Octubre de 1992). Sentencia Exp. 6631 MP[Carlos Alberto Betancourt].

Consejo de Estado, S. T. (20 de Septiembre de 1995). Sentencia Exp. 7757 MP[Juan de Dios Montes Hernández].

Consejo de Estado, Sección Tercera. (13 de Septiembre de 1999). Sentencia Exp. 10264 MP[Ricardo Hoyos Duque].

Consejo de Estado, Sección Tercera. . (24 de Agosto de 2000). Sentencia Exp. 11318. MP [Jesús María Carillo Ballesteros].

Consejo de Estado, Sección Tercera. (20 de Octubre de 2005). Sentencia Exp. 14.579 MP[Germán Rodríguez Villamizar].

Consejo de Estado, Sección Tercera. (18 de Junio de 2008). Sentencia Exp. 29.290. MP [Mauricio Fajardo Gómez] . 
Consejo de Estado, Sección Tercera. (18 de Junio de 2008). Sentencia Exp. 29.290. MP [Mauricio Fajardo Gómez] .

Consejo de Estado, Sección Tercera. (30 de Julio de 2008). Sentencia Exp. 21574 MP [Enrique Gil Botero].

Consejo de Estado, Sección Tercera. (29 de Septiembre de 2009). Sentencia Radicado Nº 2003- 0442-01 MP [Susana Valencia Buitrago].

Consejo de Estado. (22 de Abril de 2009). Sentencia Exp. 14.667 MP [Myriam Guerrero de Escobar] .

Consejo de Estado, Sección Tercera. (17 de Marzo de 2010). Sentencia Radicado № $1992-$ 0117- 01 MP [Ruth Stella Correa Palacio].

Consejo de Estado, Sección Tercera. (23 de Junio de 2010). Sentencia Radicado Nº $1994-$ 00225- 01 MP [Enrique Gil Botero].

Consejo de Estado, Sección Primera. (16 de Junio de 2011). Sentencia Radicado N ${ }^{\circ} 2002$ 05455 MP[Marco Antonio Velilla Moreno].

Consejo de Estado, Sección Tercera. (21 de Marzo de 2012). Sentencia Exp. 39477 MP [Jaime Orlando Santofimio].

Consejo de Estado. (6 de Junio de 2013). Sentencia Radicado N²009-00245-01 MP [María Elizabeth García].

Corte Suprema de Justicia. Sala de Casación Civil. (26 de Octubre de 2001). Sentencia Exp. 942. MP [Jorge Antonio Castillo Rugeles].

Corte Suprema de Justicia. Sala de Casación Civil. (9 de Noviembre de 2004). Sentencia Exp. 12789. MP [Silvio Fernando Trejos].

Corte Suprema de Justicia, Sala de Casación Civil. (6 de Julio de 2008). Sentencia C-1194 [Rodrigo Escobar Gil]. 
Corte Suprema de Justicia, S. d. (6 de Julio de 2007). Sentencia [Carlos Ignacio Jaramillo Jaramillo].

Constitucional, C. (2008). Sentencia C-1194 [Rodrigo Escobar Gil].

CORTE SUPREMA DE JUSTICIA, S. D. (16 de Diciembre de 2014). Sentencia SC172142014 MP [Jesús Vall De Rutén Ruiz].

Corte suprema de justicia, Sala de casación civil. (16 de Diciembre de 2014). Sentencia SC17214-2014 MP [Jesús Vall De Rutén Ruiz].

Corte Constitucional, Sala Séptima de Revisión de tutelas. (s.f.). Sentencia T-694/13 MP:[Jorge Ignacio Pretelt Chaljub] . Acción de Tutela instaurada por Luis Humberto Trujillo Álvarez, contra Empresa Colombiana de Petróleos ECOPETROL S.A. .

Consejo De Estado, Sala de lo Contencioso Administrativo, Sección Tercera, Subsección B. (20 de Febrero de 2014). Radicado: 68001233100020100026201 (45310),Demandante: UNIÓN TEMPORAL MANOLO ARTEAGA - PATRICIA ZAMBRANO, Demandado: ECOPETROL S.A. Asunto: ACCIÓN CONTRACTUAL.

Consejo de Estado . (2011). Sentencia 18836.

Consejo de Estado. (2010). Sentencia 17935.

Corte Constitucional. (2006). Sentencia T-209.

Rengifo García, E. (2004). Del abuso del derecho al abuso de la posición dominante. Universidad Externado de Colombia.

Valencia Zea, A., \& Ortiz Monsalve, A. (2006). Derecho civil (Vol. 1).

Hernández Velasco, H. E., \& Pardo Martínez, O. (2014). La aplicación de la teoría del abuso del derecho en la jurisprudencia colombiana,. Opinión Jurídica , 13 (26), 109-124.

Estrada, A. J. (2000). La eficacia de los derechos fundamentales entre particulares. Bogotá: Universidad Externado de Colombia. 
Sentencia C-1194/08, Bogotá, tres (3) de diciembre de dos mil ocho (2008), Referencia: expediente D-7379, Demanda de inconstitucionalidad contra el inciso final del artículo 768 y el inciso último del artículo 1932 del Código Civil, Demandante: Mónica Andrea Hoyos, Magistrado Ponente: Dr. RODRIGO ESCOBAR GIL

Ley 80 de 1993. Estatuto de la contratación administrativa. Octubre 28 de 1993

Ley 270 de 1996. Estatutaria de la administración de justicia. Marzo 7 de 1996

Ley 1150 de 2007. Por medio de la cual se introducen medidas para eficiencia y la transparencia de la Ley 80 de 1993 y se dicten otras disposiciones generales sobre la contratación con servicios públicos. Julio 16 de 2007

Ley 1437 de 2011. Por la cual se expide el código de procedimiento administrativo y de lo contencioso administrativo. Enero 18 de 2014

Ley 1474 de 2011. Por la cual se dictan normas orientadas a fortalecer los mecanismos de prevención, investigación y sanción de actos de corrupción y la efectividad de control de la gestión pública. Julio 12 de 2011 


\section{Apéndices}

Apéndice A. Manual de contratación

\begin{tabular}{||c|c|c|c|}
\hline \multirow{2}{*}{$:-7$ MTROL } & \multicolumn{3}{|c||}{ MANUAL DE CONTRATACIÓN DE ECOPETROL S.A. } \\
\cline { 2 - 4 } & \multicolumn{3}{|c|}{$\begin{array}{c}\text { GESTIÓN DE ABASTECIMIENTO } \\
\text { VICEPRESIDENCIA JURÍDICA }\end{array}$} \\
\cline { 2 - 4 } & CODIGO & Elaborado & Versión: 1 \\
\hline
\end{tabular}

TABLA DE CONTENIDO

1. OBJETIVO

2. GLOSARIO

2.1. Términos asociados a trabajadores y áreas

2.2. Términos asociados con instrumentos y figuras contractuales ............................................................ 4

2.3. Términos orientadores de las actividades de abastecimiento............................................................ 5

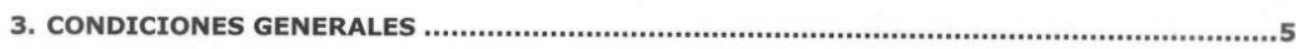

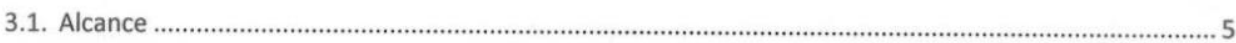

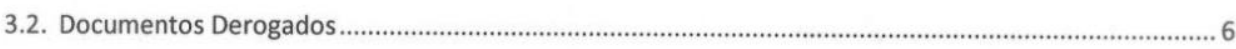

3.3. Referencia Normativa.....................................................................................................................

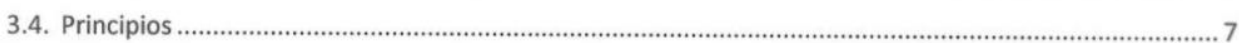

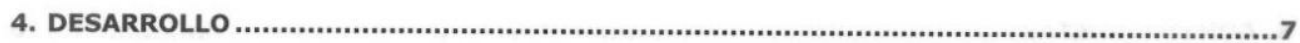

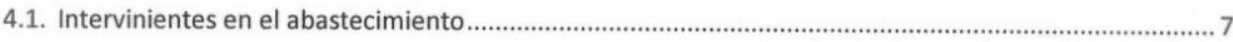

4.2. Proceso de Abastecimiento.................................................................................................................... 8

4.2.1. Planeación Estratégica............................................................................................................... 8

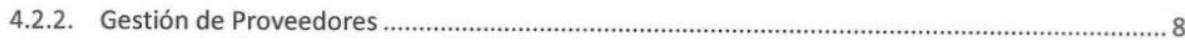

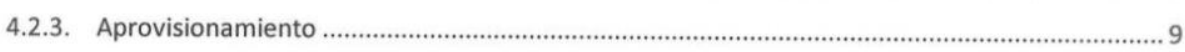

4.3. Elección de Contratista o potenciales negociadores............................................................................. 9

4.4. Aplicación del método....................................................................................................................... 10

4.5. Reglas aplicables a los diferentes métodos contractuales.................................................................. 11

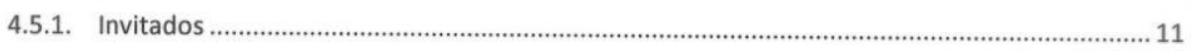

4.5.2. Ampliación de la información.................................................................................................. 11

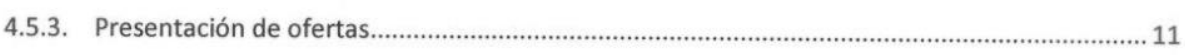

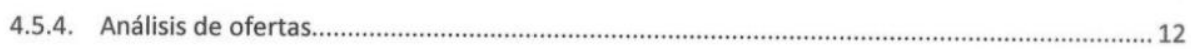

4.5.5. Conclusiones sobre el método de elección ................................................................................. 13

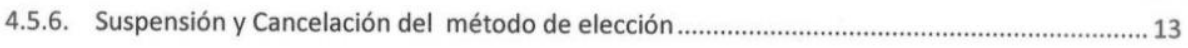

4.6. Perfeccionamiento ...................................................................................................................... 13

4.6.1. Gestión de Contratos............................................................................................................... 13

$\begin{array}{ll}\text { Plantilla } 007 & 1 / 16\end{array}$

Todos los derechos reservados para Ecopetrol S.A. Ninguna reproducción externa copia o transmisión digital de esta publicación puede ser hecha sin permiso escrito. Ningún párrafo de esta publicación puede ser reproducido, copiado o transmitido digitalmente sin un consentimiento escrito o de acuerdo con las leyes que regulan los derechos de autor y con base en la regulación vigente. 


\begin{tabular}{||c|c|c|c|}
\hline \multirow{2}{*}{$*$} & \multicolumn{3}{|c|}{ MANUAL DE CONTRATACIÓN DE ECOPETROL S.A. } \\
\cline { 2 - 4 } & \multicolumn{3}{|c|}{$\begin{array}{c}\text { GESTIÓN DE ABASTECIMIENTO } \\
\text { VICEPRESIDENCIA JURÍDICA }\end{array}$} \\
\cline { 2 - 4 } & CODIGO & Elaborado & Versión: 1 \\
\hline
\end{tabular}

4.6.2. Variaciones en las condiciones de los contratos .................................................................... 14

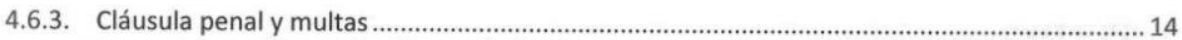

4.6.4. Terminación del vínculo contractual ................................................................................. 14

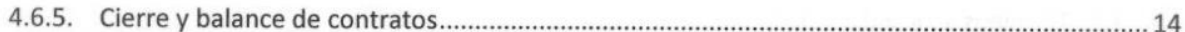

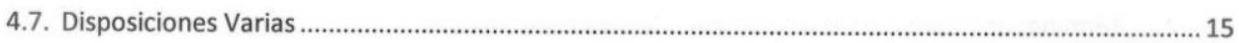

4.7.1. Formalidades de los actos contractuales ............................................................................... 15

4.7.2. Utilización de medios electrónicos......................................................................................... 15

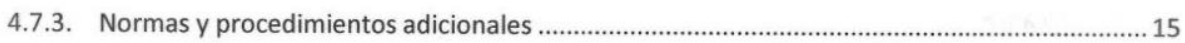

4.7.4. Legislación aplicable ................................................................................................................. 15

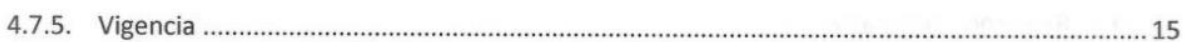

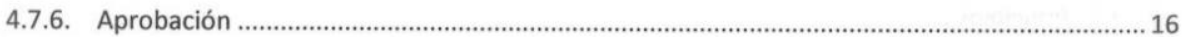

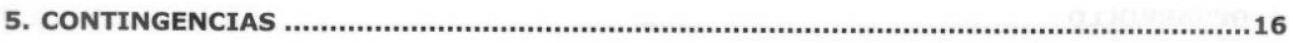

Todos los derechos reservados para Ecopetrol S.A. Ninguna reproducción externa copia o transmisión digital de esta publicación puede ser hecha sin permiso escrito. Ningún párrafo de esta publicación puede ser reproducido, copiado digital de esta publicación sin un consentimiento escrito o de acuerdo con las leyes que regulan los derechos de autor y con base en la regulación vigente. 


\begin{tabular}{||c|c|c|c|}
\hline \multirow{2}{*}{$:-7$ METROL } & \multicolumn{3}{|c|}{ MANUAL DE CONTRATACIÓN DE ECOPETROL S.A. } \\
\cline { 2 - 4 } & \multicolumn{3}{|c|}{$\begin{array}{c}\text { GESTIÓN DE ABASTECIMIENTO } \\
\text { VICEPRESIDENCIA JURÍDICA }\end{array}$} \\
\cline { 2 - 4 } & $\begin{array}{c}\text { Elaborado } \\
\text { CODIGO } \\
\text { GAB-M-001 }\end{array}$ & $20 / 12 / 2016$ & Versión: 1 \\
\hline
\end{tabular}

1. OBJETIVO

El Manual de Contratación se define como el marco normativo que orienta las actividades de abastecimiento de bienes y servicios, que adelanta Ecopetrol S.A. directamente, en su propio nombre y cuenta, y, cuando así se disponga en el acuerdo, acto o contrato, en nombre y por cuenta de terceros.

\section{GLOSARIO}

Para todos los efectos del Manual de Contratación, los términos que a continuación se relacionan tendrán el significado que seguidamente se les asigna.

Los términos que sean descritos en singular también incluyen el plural y viceversa, siempre y cuando el contexto de lo que se establezca en el presente Manual así lo determine.

\subsection{Términos asociados a trabajadores y áreas}

Administrador de Contrato: Responsable integral del relacionamiento y de la gestión contractual que demande el contrato administrado; debe prestar especial cuidado en las verificaciones necesarias para dar recibo a satisfacción de los bienes o servicios contratados, lo cual sustenta y habilita los pagos correspondientes a las obligaciones establecidas en el contrato.

Áreas intervinientes en el proceso de abastecimiento: Áreas expertas en sus distintas disciplinas, que resuelven y se hacen responsables por su intervención en el mencionado proceso, de acuerdo con su especialidad; acompañan en las decisiones y actuaciones a los funcionarios competentes en cada una de las etapas del proceso,

Área Solicitante: Cualquier área de Ecopetrol S.A. que actúe como solicitante de bienes y servicios (áreas de negocio, áreas corporativas y de soporte, y la misma área de abastecimiento). Tiene a su cargo la planeación; alineación entre las necesidades de abastecimiento de su área y el presupuesto que respalda la contratación de dichas necesidades; entrega las especificaciones técnicas, asegura la disponibilidad de presupuesto, consolida y desarrolla el Plan Integrado de Abastecimiento de su área y valora las condiciones de criticidad, impacto y valor en la contratación.

Experto Técnico de Categoría: Trabajador del Área Solicitante, con el conocimiento y experiencia necesarios, que debe hacer equipo con el Ejecutivo de Categoría o quien haga sus veces. Tiene por rol principal responder y respaldar los aspectos y exigencias técnicas de la contratación de bienes y servicios que ha sido identificada en su área como necesaria.

Funcionario Autorizado: Trabajador de Ecopetrol S.A., facultado para contratar en representación de la Sociedad; o en nombre y por cuenta de terceros, cuando se le haya encomendado por delegación, contrato o poder, para dicha actividad, conforme a los niveles de autorización establecidos por Ecopetrol S.A. para el efecto, y en consecuencia, está autorizado para adelantar las contrataciones bajo la metodología que se haya establecido para el efecto; celebrar, modificar y llevar a cabo las acciones tendientes a terminar o finalizar el contrato respectivo en los estrictos términos y facultades que se le hayan conferido.

Funcionario Solicitante: Trabajador de Ecopetrol S.A facultado para solicitar al Área de Abastecimiento, la contratación de bienes y servicios, de conformidad con la planeación y requerimientos de su Área.

Todos los derechos reservados para Ecopetrol S.A. Ninguna reproducción externa copia o transmisión digital de esta publicación puede ser hecha sin permiso escrito. Ningún párrafo de esta publicación puede ser reproducido, copiado o transmitido digitalmente sin un consentimiento escrito o de acuerdo con las leyes que regulan los derechos de autor y con base en la regulación vigente. 


\begin{tabular}{||c|c|c|c|}
\hline \multirow{3}{*}{$: 40 T R O L$} & \multicolumn{3}{|c|}{ MANUAL DE CONTRATACIÓN DE ECOPETROL S.A. } \\
\cline { 2 - 4 } & \multicolumn{3}{|c|}{$\begin{array}{c}\text { GESTIÓN DE ABASTECIMIENTO } \\
\text { VICEPRESIDENCIA JURÍdICA }\end{array}$} \\
\cline { 2 - 4 } & CODIGO & Elaborado & Versión: 1 \\
\hline
\end{tabular}

Jefe Departamento de Dominio o quien haga sus veces: Trabajador del área de abastecimiento que tiene bajo su dirección la visión integrada de varias categorías clave de bienes y servicios. Es el responsable de asegurar el funcionamiento de las categorías a su cargo, el relacionamiento estratégico con los proveedores que las abastecen y es Funcionario Autorizado de los contratos de sus categorías que por el impacto y cuantía se le asignen.

Ejecutivo de Categoría o quien haga sus veces: Trabajador del área de abastecimiento, responsable de la categoría de bienes y servicios asignada dentro del correspondiente dominio. Dentro de las actividades a su cargo, se destacan: disponer anticipadamente los vehículos comerciales para atender las necesidades de aprovisionamiento de su categoría, liderar la construcción de las estrategias de aprovisionamiento asociadas a su categoría; celebrar como Funcionario Autorizado y bajo el aseguramiento de la estrategia aprobada, los contratos de la categoría de bienes y servicios respectivos; hacer seguimiento al cumplimiento de la estrategia y a la promesa de valor asociada a la misma durante la ejecución de los contratos.

\subsection{Términos asociados con instrumentos y figuras contractuales}

Acuerdo de Bases Económicas (ABE): Es el acuerdo que Ecopetrol S.A. celebra con un proveedor de bienes o servicios, que incluye los precios de éstos en unas condiciones técnicas y comerciales determinadas, para una eventual contratación futura.

El área de abastecimiento es responsable de determinar las calidades de los proveedores con quienes se suscriban los Acuerdos de Bases Económicas.

El Acuerdo de Bases Económicas no constituye un contrato, y, por consiguiente, no es fuente de obligaciones contractuales entre las Partes. Su ejecución se hará a través de órdenes de compra y/o de servicios emitidas por el Funcionario Autorizado de Ecopetrol S.A., conforme a las definiciones previstas en el Acuerdo.

Contratación Ágil: Instrumento que procede para el aprovisionamiento de bienes y servicios definidos en el cuadrante de bienes y servicios rutinarios de la Matriz de Posición de Aprovisionamiento o para contrataciones a las que aplicare la Metodología basada en negociación bilateral. Este instrumento se caracteriza por la participación del Área Solicitante que formula un requerimiento para el aprovisionamiento mediante misiva electrónica o llamada telefónica, y el área de abastecimiento lo aprueba por "ticket". El desarrollo del proceso generalmente se hace a través de llamadas telefónicas grabadas con el proveedor seleccionado o mediante compra en almacenes de grandes superficies o especializados o mediante el uso de tarjeta de crédito.

Contratación de Emergencia: Instrumento de contratación que busca responder a situaciones que demandan la necesidad de realizar actividades o trabajos de forma inmediata y que por lo mismo requieren la contratación de determinados bienes y servicios de manera ágil y expedita, cuando se presenten circunstancias que (i) afecten o amenacen afectar de manera grave la explotación o producción de los hidrocarburos, la refinación de los mismos o, en general, el abastecimiento de combustibles; o (ii) amenacen o afecten la continuidad y seguridad de la operación, del personal involucrado o del funcionamiento normal de instalaciones, plantas o equipos.

Contratación por necesidades imprevisibles: Instrumento de contratación que procede cuando el aprovisionamiento de la necesidad en particular se requiere inmediatamente, $\sin$ que haya podido abastecerse de manera anticipada por ser imprevisible. La contratación por necesidades imprevisibles

Todos los derechos reservados para Ecopetrol S.A. Ninguna reproducción externa copia o transmisión digital de esta publicación puede ser hecha sin permiso escrito. Ningún párrafo de esta publicación puede ser reproducido, copiado o transmitido digitalmente sin un consentimiento escrito o de acuerdo con las leyes que regulan los derechos de autor y con base en la regulación vigente. 


\begin{tabular}{||c|c|c|c|}
\hline \multirow{2}{*}{ MeTROL } & \multicolumn{3}{|c|}{ MANUAL DE CONTRATACIÓN DE ECOPETROL S.A. } \\
\cline { 2 - 4 } & \multicolumn{3}{|c|}{$\begin{array}{c}\text { GESTIÓN DE ABASTECIMIENTO } \\
\text { VICEPRESIDENCIA JURÍdICA }\end{array}$} \\
\cline { 2 - 4 } & $\begin{array}{c}\text { Elaborado } \\
\text { GAB-M-001 }\end{array}$ & $20 / 12 / 2016$ & Versión: 1 \\
\hline
\end{tabular}

en Ecopetrol S.A. tendrá medición y control mensual. Su solicitud debe provenir del funcionario al que se asigne esta facultad.

Acuerdo marco con negociación: Instrumento estratégico que procede para contratar a largo plazo categorías clave de bienes y servicios. Se desarrolla mediante órdenes de compra u órdenes de servicio puntuales con plazo y precio asociados. Antes de la emisión de la respectiva orden por el Funcionario Autorizado se agotará la etapa de negociación de precios entre quienes tengan celebrado acuerdos marco con negociación para el bien o el servicio respectivo.

Acuerdo marco sin negociación: Instrumento estratégico que procede para contratar a largo plazo categorías clave de bienes y servicios de precio inelástico y de baja competencia. Se desarrolla mediante órdenes de compra u órdenes de servicio puntuales, con plazo y precio asociados sin que pueda modificarse, ni adicionarse lo pactado eh el Acuerdo marco correspondiente.

Contratación puntual: Usada para compras y contrataciones sin instrumentos de anticipación de demanda disponibles, y que no correspondan a los mecanismos asociados con la contratación por necesidades imprevisibles o contratación de emergencia.

Lista de Precios Unitarios Fijos: Es el documento elaborado y aprobado por Ecopetrol S.A., en el que se consigna el valor unitario de cada uno de los ítems, (unidades de recurso, obras, trabajo, bienes) relacionados con una actividad, y que aplica durante un periodo determinado.

\subsection{Términos orientadores de las actividades de abastecimiento}

Gestión de Riesgos: Es la manera organizada y estructurada de evaluar los efectos positivos y negativos de la toma de decisiones en el proceso y gestión contractual.

Matriz de Posicionamiento de Aprovisionamiento: Herramienta que clasifica los bienes y servicios de acuerdo con los siguientes criterios: (i) riesgo (ii) impacto en la operación; (iii) gasto de la contratación. Los cuadrantes donde terminen ubicados, (rutinarios o consumibles, cuello de botella o necesarios, de palanca o habilitadores y críticos), tienen impacto directo en el mecanismo para escoger al contratista final o negociadores y en el tipo de contrato a celebrar.

PAI: Plan de Abastecimiento Integral.

SIPROE: Herramienta que habilita el auto registro de los proveedores de bienes y servicios requeridos por Ecopetrol S.A. La información del auto registro y la adicional que se requiera para determinada categoría de bienes y servicios, será objeto de verificación y permitirá identificar a los potenciales proveedores idóneos para presentar oferta.

\section{CONDICIONES GENERALES}

\subsection{Alcance}

Este Manual se tendrá en cuenta para el abastecimiento de bienes y servicios adelantado por Ecopetrol S.A., en su propio nombre y cuenta, y cuando actúe en nombre y por cuenta de terceros en los casos en que así se haya definido en el acuerdo, acto o contrato. Las actividades de abastecimiento de bienes y servicios reguladas por este Manual, comprenden la planeación estratégica del aprovisionamiento de bienes y servicios, el alistamiento y la gestión de los proveedores de bienes y servicios, el

Plantilla 007

Todos los derechos reservados para Ecopetrol S.A. Ninguna reproducción externa copia o transmisión digital de esta publicación puede ser hecha sin permiso escrito. Ninguún párrafo de esta publicación puede ser reproducido, copiado o transmitido digitalmente sin un consentimiento escrito o de acuerdo con las leyes que regulan los derechos de autor y con base en la regulación vigente. 


\begin{tabular}{|c|c|c|c|}
\hline & MANUAL & TACIÓN DE EC & S.A. \\
\hline & & $\begin{array}{l}\text { ABASTECIMI } \\
\text { DENCIA JURÍ́ }\end{array}$ & \\
\hline$=0$ & $\begin{array}{c}\text { CODIGO } \\
\text { GAB-M-001 }\end{array}$ & $\begin{array}{c}\text { Elaborado } \\
20 / 12 / 2016\end{array}$ & Versión: 1 \\
\hline
\end{tabular}

aprovisionamiento anticipado y ajustado a una estrategia, la supervisión y gestión diferenciada de los contratos.

Este Manual no aplicará para los procesos que no se encuentren comprendidos por Ecopetrol S.A. como parte del proceso de abastecimiento de bienes y servicios. Dentro de los que se encuentran excluidos, a modo de ejemplo, se destacan los siguientes:

a. Cuando se trate de Contratos de Colaboración, Asociación o Participación, Alianzas Estratégicas o contratos societarios de cualquier tipo, que tengan por finalidad el desarrollo del objeto social de Ecopetrol S.A.

b. Cuando se trate de Convenios.

c. Cuando se determine que adherirse a contratos vigentes, emprendidos o celebrados por Ecopetrol S.A. -siendo operador o mandatario o figura similar- sea la mejor opción o negocio para atender las respectivas necesidades de contratación de la Empresa.

d. Cuando Ecopetrol S.A. actúe como contratista -proveedor o suministrador de un bien o de un servicio o ejecutor de un trabajo a favor de un tercero- (incluye los contratos de logística inversa), o cuando subcontrate para cumplir con sus obligaciones de contratista.

e. Cuando se trate de compra y venta de materias primas y productos (hidrocarburos, derivados y productos, fuentes convencionales y alternativas de energía, componentes oxigenantes y biocombustibles),

f. Cuando se trate de operaciones financieras, gestión de las personas y la organización, contratos de asociación, inversión y desinversión de activos.

El presente Manual podrá ser utilizado como guía o criterio orientador de los procesos de adquisición de bienes y servicios que no correspondan al proceso de abastecimiento de Ecopetrol S.A., si así lo disponen las áreas responsables de aquellos procesos.

\subsection{Documentos Derogados}

Manual de Contratación Ecopetrol S.A. Versión 1, y cualquier normativa interna ${ }^{1}$ que regule, incorpore - afecte el abastecimiento de bienes y servicios de Ecopetrol S.A. y que sea incompatible con lo establecido en este Manual.

Los procesos de selección que se encuentren en curso con anterioridad a la entrada en vigor del presente Manual, así como los contratos en ejecución (incluyendo los contratos adicionales u otrosíes que se suscriban con posterioridad a la emisión del presente Manual) o en liquidación, seguirán rigiéndose por el Manual y por las normas vigentes al momento de la iniciación del proceso de contratación o de la suscripción del respectivo contrato o del contrato primigenio.

1 Independiente de la denominación del documento en gestión documental: circular, directriz, manual, memorando, procedimiento y cualquier otra.

Plantilla 007

$6 / 16$

Todos los derechos reservados para Ecopetrol S.A. Ninguna reproducción externa copia o transmisión digital de esta publicación puede ser hecha sin permiso escrito. Ningún párrafo de esta publicación puede ser reproducido, copiado o transmitido digitalmente sin un consentimiento escrito o de acuerdo con las leyes que regulan los derechos de autor y con base en la regulación vigente. 


\begin{tabular}{|c|c|c|c|}
\hline & MANUAL & ITACIÓN DE EC & S.A. \\
\hline & & $\begin{array}{l}\text { E ABASTECIMII } \\
\text { DENCIA JURÍD }\end{array}$ & \\
\hline - & $\begin{array}{c}\text { CODIGO } \\
\text { GAB-M-001 }\end{array}$ & $\begin{array}{c}\text { Elaborado } \\
20 / 12 / 2016\end{array}$ & Versión: 1 \\
\hline
\end{tabular}

\subsection{Referencia Normativa}

El Manual de Contratación ha sido elaborado teniendo en cuenta que para todos los actos jurídicos, societarios, contratos, procedimientos y actividades necesarias para administrar y desarrollar el objetivo de Ecopetrol S.A., aplica el derecho privado y las demás disposiciones jurídicas que regulan la actividad y que le sean extensivas a los demás agentes económicos con los que concurre en el sector energético; en condiciones de igualdad y competitividad, de conformidad con la ley y sus estatutos sociales (artículo 6 de la Ley 1118 de 2006).

\subsection{Principios}

De acuerdo con lo indicado por el artículo 6 de la Ley 1118 de 2006, "todos los actos jurídicos, contratos y actuaciones necesarias para administrar y desarrollar el objeto social de Ecopetrol S. A., una vez constituida como sociedad de economía mixta, se regirán exclusivamente por las reglas del derecho privado, sin atender el porcentaje del aporte estatal dentro del capital social de la empresa".

Aquel referente normativo le impone a Ecopetrol S.A. adelantar sus actuaciones contractuales a partir de los principios y reglas que fundamentan el derecho privado, y, de manera acorde con el régimen jurídico de Ecopetrol S.A., los principios jurídicos que la legislación establezca, que tengan en cuenta y que estén acordes con las características de las actividades que desarrolla Ecopetrol S.A. como agente económico que interactúa en condiciones de igualdad y competitividad en el sector energético.

\section{DESARROLLO}

\subsection{Intervinientes en el abastecimiento}

El abastecimiento en Ecopetrol S.A. se ejecuta bajo un esquema de segregación de funciones, consistente en diferenciar los roles de pedir y contratar, el cual garantiza que las decisiones no estén concentradas en un área o persona; además exige el debate interdisciplinario y la trazabilidad de las decisiones.

La contratación de bienes y servicios será adelantada única y exclusivamente por los trabajadores facultados para representar a Ecopetrol S.A. en esta materia. Para efectos del presente Manual, se entenderá que la persona con capacidad para contratar corresponde al Funcionario Autorizado. En cuanto a los Funcionarios Solicitantes de abastecimiento, están facultados para hacer las solicitudes de contratación de conformidad con el plan de abastecimiento integral del respectivo negocio o área corporativa.

La identificación de los Funcionarios Solicitantes, Funcionarios Autorizados y las cuantías límite de sus actuaciones en materia de abastecimiento de bienes y servicios, serán las que sean establecidas corporativamente por Ecopetrol S.A.

Ecopetrol S.A. aplicará el régimen de inhabilidades e incompatibilidades previsto para la contratación estatal, ordenado por los artículos 13 y 14 de la Ley 1150 de 2007 o las disposiciones que las deroguen o sustituyan. Igualmente, se tendrán en cuenta las previsiones que sobre la materia han sido incluidas en el Código de Buen Gobierno y en los Estatutos Sociales.

Todos los derechos reservados para Ecopetrol S.A. Ninguna reproducción externa copia o transmisión digital de esta publicación puede ser hecha sin permiso escrito. Ningún párrafo de esta publicación puede ser reproducido, copiado o transmitido digitalmente
sin un consentimiento escrito o de acuerdo con las leyes que regulan los derechos de autor y con base en la regulación vigente. 


\begin{tabular}{|l|c|c|c|}
\hline \multirow{2}{*}{} & \multicolumn{3}{|c||}{ MANUAL DE CONTRATACIÓN DE ECOPETROL S.A. } \\
\cline { 2 - 4 } & \multicolumn{3}{|c|}{$\begin{array}{c}\text { GESTIÓN DE ABASTECIMIENTO } \\
\text { VICEPRESIDENCIA JURÍdICA }\end{array}$} \\
\hline \multirow{2}{*}{ VITROL } & CODIGO & Elaborado & Versión: 1 \\
\cline { 2 - 4 } & GAB-M-001 & $20 / 12 / 2016$ & \\
\hline
\end{tabular}

\subsection{Proceso de Abastecimiento}

El abastecimiento comprende los procesos que se describen a continuación:

\subsubsection{Planeación Estratégica}

Se sujetarán a planeación estratégica las categorías de bienes y servicios contratadas por Ecopetrol S.A., que estarán agrupadas en dominios de categorías, entre otras, servicios petroleros, compras, obras, operación y mantenimiento, soporte y servicios.

Este subproceso tiene por objetivo anticipar y planear la atención de las necesidades de compras y contratación de Ecopetrol S.A. mediante el aseguramiento del Plan de Abastecimiento Integral. Sus actividades críticas están orientadas al análisis de la demanda interna y del mercado, a consolidar los estándares técnicos aplicables por categoría, a identificar los proveedores idóneos, a priorizar las palancas de ahorros, a seleccionar y aprobar la estrategia de contratación, teniendo en cuenta las previsiones que se contemplan en este Manual; a establecer, previo análisis de riesgos, el tipo de garantías requeridas, los amparos, así como la cuantía de las mismas, y a monitorear la implantación y el desempeño de la estrategia.

El insumo principal dentro de la planeación estratégica de la función de abastecimiento en Ecopetrol S.A., corresponde a la alineación entre el Plan Financiero y el aseguramiento del Plan de Abastecimiento Integral en su fase de alto nivel, lo cual sustenta el Marco Estratégico y el Plan de Negocios de la Compañía.

En la construcción del Plan de Abastecimiento Integral se tendrá en cuenta lo consignado en los instrumentos de planeación financiera de Ecopetrol S.A. (Portafolio, Plan de Inversiones, Plan plurianual, entre otros).

Los indicadores del subproceso de planeación estratégica medirán los ahorros por la gestión de abastecimiento, el cumplimiento del Plan de Abastecimiento Integral, la cobertura estratégica del gasto, la madurez de la cadena de abastecimiento y la concentración del gasto.

\subsubsection{Gestión de Proveedores}

El objetivo de la gestión de proveedores es alistar, gestionar y mantener la base de datos de los potenciales ofertantes, y desarrollar un relacionamiento segmentado con proveedores; sus actividades críticas se orientan a la identificación del portafolio de proveedores, objetivo actualizado y listo para contratar, y al aseguramiento de buenas relaciones con los proveedores.

Se parte del universo indeterminado de proveedores de bienes y servicios requeridos por Ecopetrol S.A., quienes tienen la posibilidad de auto registrarse voluntariamente en el Sistema de Información de Proveedores (SIPROE). Así mismo se gestionará el registro de otros proveedores objetivo no auto registrados. A todos se les verificará la información suministrada, para lograr la identificación de proveedores verificados, que será objeto de actualización y revisión continua.

Serán objeto de especial seguimiento los requisitos de capacidad financiera, desempeño del proveedor, experiencia exitosa y exigencias éticas (lavado de activos y financiación de terrorismo (LAFT), el compromiso con la integridad contractual, impedimentos, inhabilidades, incompatibilidades y conflictos de interés para contratar, entre otros).

Todos los derechos reservados para Ecopetrol S.A. Ninguna reproducción externa copia o transmisión digital de esta publicación puede ser hecha sin permiso escrito. Ningún párrafo de esta publicación puede ser reproducido copiado o transmitido digitaimente sin un consentimiento escrito 


\begin{tabular}{|c|c|c|c|}
\hline \multirow{3}{*}{ : fPeTROL } & \multicolumn{3}{|c|}{ MANUAL DE CONTRATACIÓN DE ECOPETROL S.A. } \\
\hline & \multicolumn{3}{|c|}{$\begin{array}{l}\text { GESTIÓN DE ABASTECIMIENTO } \\
\text { VICEPRESIDENCIA JURÍDICA }\end{array}$} \\
\hline & $\begin{array}{c}\text { CODIGO } \\
\text { GAB-M-001 }\end{array}$ & $\begin{array}{c}\text { Elaborado } \\
\text { 20/12/2016 }\end{array}$ & Versión: 1 \\
\hline
\end{tabular}

La medición de la gestión de proveedores tendrá en cuenta el desempeño de proveedores por categoría, asegurando una evaluación segmentada y útil; cobertura de desempeño registrada y efectividad, para uso de Ecopetrol S.A. y el grupo empresarial, funciones que están adscritas al SIPROE.

\subsubsection{Aprovisionamiento}

El objetivo del subproceso de aprovisionamiento consiste en ejecutar las compras y contrataciones, la operación, el mantenimiento y los proyectos de Ecopetrol S.A., asegurando niveles óptimos de costo, oportunidad y calidad del bien o del servicio contratado.

Para el efecto, deberá gestionarse al máximo posible y de manera anticipada, el aprovisionamiento incorporado en el Plan de Abastecimiento Integral, mediante procesos y figuras comerciales diferenciadas por el tipo de contrato, en concordancia con la criticidad de la categoría y el suministro, tales como, la Contratación Ágil, Contratos de Anticipación de la Demanda, Acuerdos de Bases Económicas, Acuerdos Marco con Negociación, Acuerdos Marco sin Negociación, Contratación por Necesidades Imprevisibles, Contratación Puntual y Contratación de Emergencia.

De manera consistente con el bien o el servicio que se requiera abastecer y la forma de contratación que se apruebe, será necesaria la definición de los términos y condiciones del contrato, la lista de proveedores idóneos, la identificación de criterios técnicos, económicos y otros requeridos para la evaluación de las ofertas o los rangos de negociación si resultan aplicables, la estimación de cantidades, la entrega de especificaciones técnicas y la obtención de permisos o licencias, la necesidad de garantías y seguros y de garantías del fabricante, la construcción de la documentación regla del método de elección de contratistas, el cronograma del mismo y las actividades o insumos señalados de acuerdo con la planeación.

Los indicadores del subproceso de aprovisionamiento estarán orientados a medir el tiempo de selección y contratación.

\subsection{Elección de Contratista o potenciales negociadores}

Los bienes y servicios de las principales categorías se contratarán conforme a la estrategia adoptada por el Comité de Estrategia de Abastecimiento y los aspectos orientadores establecidos en este Manual, los cuales también se tendrán en cuenta para el abastecimiento de bienes y servicios que no correspondan a las principales categorias.

La contratación asociada al abastecimiento de bienes y servicios responde a una metodología. Dentro de los métodos que se destacan se encuentran los siguientes:

a. Metodología basada en negociación bilateral: Proceso mediante el cual se negocia y, en caso de que proceda, se contrata con una persona capaz e idónea, con fundamento en una oferta favorable resultante de una negociación integral.

b. Metodología basada en requisición para competir: Proceso en que pueden presentar oferta varias personas, y, con base en factores competitivos o de negociación, se identifica el ofrecimiento más favorable.

Todos los derechos reservados para Ecopetrol S.A. Ninguna reproducción externa copia o transmisión digital de esta publicación puede ser hecha sin permiso escrito. Ningún párrafo de esta publicación puede ser reproducido, copiado o transmitido digitalmente sin un consentimiento escrito o de acuerdo con las leyes que regulan los derechos de autor y con base en la regulación vigente. 


\begin{tabular}{|c|c|c|c|}
\hline \multirow{3}{*}{ :PETROL } & \multicolumn{3}{|c|}{ MANUAL DE CONTRATACIÓN DE ECOPETROL S.A. } \\
\hline & \multicolumn{3}{|c|}{$\begin{array}{l}\text { GESTIÓN DE ABASTECIMIENTO } \\
\text { VICEPRESIDENCIA JURÍDICA }\end{array}$} \\
\hline & $\begin{array}{c}\text { CODIGO } \\
\text { GAB-M-001 }\end{array}$ & $\begin{array}{c}\text { Elaborado } \\
20 / 12 / 2016\end{array}$ & Versión: 1 \\
\hline
\end{tabular}

Las solicitudes de oferta que realice Ecopetrol S.A. no constituyen oferta comercial. En consecuencia, no la obligan a celebrar el contrato correspondiente, pudiendo calificar el proceso basado en las metodologías indicadas, como fallido o proceder a su cancelación por los motivos que para Ecopetrol S.A. justifiquen o expliquen dicho proceder.

\subsection{Aplicación del método}

La aplicación de la metodología orientada a la contratación de bienes y servicios, hace parte de los aspectos a ser incluidos en la planeación de la actividad de abastecimiento. En dicho ejercicio de planeación, será pertinente considerar los siguientes criterios predominantes, no exclusivos, sobre las metodologías señaladas:

a. Metodología basada en negociación bilateral: La utilización de esta metodología responderá a los aspectos que desde la planeación se hayan identificado para el logro de los objetivos en materia de abastecimiento de bienes y servicios, y al régimen jurídico aplicable. En esa medida, la presente metodología estará al servicio de escenarios o situaciones que así lo requieran, destacándose, entre otras, las siguientes:

I. Cuando se presente una situación calificada como contratación de Emergencia por el Vicepresidente del área respectiva.

II. Cuando la necesidad sea satisfecha mediante el instrumento de contratación por necesidades imprevisibles.

III. Contrataciones en que el valor del objeto del contrato no sobrepase los cien salarios mínimos legales mensuales (100 S.M.L.M.), sin incluir IVA.

IV. Contrataciones llamadas a celebrarse con una persona determinada (servidumbre, arrendamiento, comodato o adquisición de bienes inmuebles, titular del derecho de propiedad intelectual o su representante, compra a fabricantes, distribuidores únicos o representantes exclusivos por requerirse técnicamente, de marcas determinadas, contratos intuito personae).

V. Contratación de médicos, especialistas y hospitales, fundamentada en la red de prestadores de salud de Ecopetrol S.A.

VI. Compra de cuota parte de bienes de los cuales sea copropietaria o comunera Ecopetrol S.A.

VII. Prueba o ensayo de bienes y servicios, con el fin de evaluar la introducción de nuevas tecnologías, posibles cambios de las mismas o en busca de mejores alternativas, y conforme a la reglamentación del Instituto Colombiano del Petróleo.

VIII. Contratos de cobertura de riesgo de precio y riesgo crediticio (garantías silenciosas); contratos de suscripciones para información de mercado internacional de hidrocarburos, de normativa, de precios de mercado, a información de "Vetting" de buque tanques, a servicios de rastreo de buque tanques, sobre riesgo crediticio; pólizas de responsabilidad civil por polución.

b. Metodología basada en requisición para competir: método basado en un proceso competitivo de elección de contratistas o de ofertantes para una eventual negociación, que toma en cuenta factores

Todos los derechos reservados para Ecopetrol S.A. Ninguna reproducción externa copia o transmisión digital de esta publicación puede ser hecha sin permiso escrito. Ningún párrafo de esta publicación puede ser reproducido, copiado o transmitido digitalmente $\sin$ un consentimiento escrito o de acuerdo con las leyes que regulan los derechos de autor y con base en la regulación vigente. 


\begin{tabular}{|c|c|c|c|}
\hline \multirow{3}{*}{ : - PETROL } & \multicolumn{3}{|c|}{ MANUAL DE CONTRATACIÓN DE ECOPETROL S.A. } \\
\hline & \multicolumn{3}{|c|}{$\begin{array}{l}\text { GESTIÓN DE ABASTECIMIENTO } \\
\text { VICEPRESIDENCIA JURÍDICA }\end{array}$} \\
\hline & $\begin{array}{c}\text { CODIGO } \\
\text { GAB-M-001 }\end{array}$ & $\begin{array}{c}\text { Elaborado } \\
20 / 12 / 2016\end{array}$ & Versión: 1 \\
\hline
\end{tabular}

competitivos o de negociación definidos por Ecopetrol S.A., a partir de la puja en costos y condiciones de aprovisionamiento.

\subsection{Reglas aplicables a los diferentes métodos contractuales}

\subsubsection{Invitados}

En categorías clave de bienes y servicios el Comité de Estrategias de Abastecimiento aprobará la estrategia de contratación y la lista de proveedores idóneos registrados en el SIPROE.

En los demás bienes y servicios, el área de abastecimiento con el apoyo del área de negocio, identificará los invitados, basados en la lista de proveedores idóneos, o las condiciones a exigir a los convocados, quienes deben estar registrados o incluirse en el SIPROE.

En cualquier caso se seguirán los lineamientos del subproceso de gestión de proveedores.

\subsubsection{Ampliación de la información}

Ecopetrol S.A. podrá celebrar una visita al sitio de ejecución del objeto del contrato y/o una audiencia con el propósito de observar las condiciones del lugar de ejecución del contrato, precisar el alcance de la contratación, el contenido de los documentos que le sirven de soporte, y resolver las inquietudes a que haya lugar, de lo cual se levantará un acta suscrita por el Funcionario Autorizado de la contratación, que se dará a conocer a todos los interesados.

Adicionalmente, los interesados podrán solicitar aclaraciones para despejar cualquier aspecto en relación con la documentación del método de elección.

Las modificaciones a la documentación se efectuarán mediante Adenda firmada por el Funcionario Autorizado.

\subsubsection{Presentación de ofertas}

Las ofertas se podrán presentar por cualquier medio previsto por la Ley, en la forma y oportunidad que se indique en la documentación del método de elección, para lo cual se dispondrá de los mecanismos, instrumentos, canales y garantías que permitan la efectividad del método de elección, los derechos y
garantías de los ofertantes.

Igualmente, se podrá autorizar, sin limitarse a ello, la presentación de (i) ofertas alternativas, indicando de manera clara y precisa las condiciones para su evaluación y aceptación; (ii) ofertas bajo la modalidad de subasta, la cual podrá ser electrónica, o bajo la modalidad interactiva, sin que dichas modalidades sean excluyentes, pudiendo, en consecuencia, ser complementarias.

Bajo la modalidad interactiva podrá haber lugar a asignaciones sucesivas. Para el efecto, quienes cumplan los aspectos técnicos mínimos y/o superen el puntaje o porcentaje mínimo atribuido a éstos, podrán presentar ofrecimientos sucesivos (técnicos y económicos), según Ecopetrol S.A. Io vaya requiriendo, de cada uno de los cuales puede resultar la asignación o negociación de un contrato independiente.

Todos los derechos reservados para Ecopetrol S.A. Ninguna reproducción externa copia o transmisión digital de esta publicación puede ser hecha sin permiso escrito. Ningún párrafo de esta publicación puede ser reproducido, copiado o transmitido digitalmente sin un consentimiento escrito o de acuerdo con las leyes que regulan los derechos de autor y con base en la regulación vigente. 


\begin{tabular}{|c|c|c|c|}
\hline \multirow{3}{*}{ :PETROL } & \multicolumn{3}{|c|}{ MANUAL DE CONTRATACIÓN DE ECOPETROL S.A. } \\
\hline & \multicolumn{3}{|c|}{$\begin{array}{l}\text { GESTIÓN DE ABASTECIMIENTO } \\
\text { VICEPRESIDENCIA JURÍDICA }\end{array}$} \\
\hline & $\begin{array}{c}\text { CODIGO } \\
\text { GAB-M-001 } \\
\end{array}$ & $\begin{array}{c}\text { Elaborado } \\
20 / 12 / 2016\end{array}$ & Versión: 1 \\
\hline
\end{tabular}

La presentación de cualquier oferta a Ecopetrol S.A. estará acompañada de una manifestación del respectivo ofertante en la que conste que conoce este Manual de Contratación de manera completa y su aceptación expresa de todas las condiciones y las normas estipuladas en el mismo. Cuando la oferta ha de presentarse por escrito, la referida manifestación se deberá entregar también por escrito a Ecopetrol S.A., conjuntamente con la oferta. Si la oferta se da a conocer a Ecopetrol S.A. de manera verbal, se acordará una fórmula entre el ofertante y Ecopetrol S.A. para dejar constancia de la misma. La falta del requisito podrá ser subsanada por el ofertante.

Si el método de elección implica negociación o presentación de ofertas durante conversaciones telefónicas, se tendrá en cuenta lo siguiente:

a. Las conversaciones telefónicas serán grabadas, quedando registradas por este medio las ofertas presentadas o las respuestas sobre no participación. Ecopetrol S.A. informará a los ofertantes que las conversaciones son objeto de grabación.

b. Con los sistemas electrónicos de grabación telefónica se podrán validar como ofertas formales las realizadas por este medio, teniendo en cuenta que bajo esa modalidad quedarán registradas las respectivas conversaciones $y$, por ende, los ofrecimientos realizados por los ofertantes. El contenido de la grabación se plasmará por escrito para dejar evidencia documental de la oferta.

c. De la negociación siempre se dejará registro (grabación telefónica, filmación de la mesa, acta de la reunión o cualquier otro). El área de abastecimiento dejará constancia escrita y debidamente documentada de los antecedentes de la negociación, la situación de mercado, el margen de precios aceptables, las características sobre el desarrollo de la negociación, el conocimiento por parte del ofertante de la totalidad del Manual de Contratación, la aceptación expresa del ofertante sobre la aplicación de las normas establecidas en el Manual de Contratación y demás aspectos relacionados con la asignación o negociación del contrato. Las grabaciones o cualquier otro medio técnico utilizado para los efectos aquí indicados, tendrán la calidad de documento y los efectos probatorios que la Ley le concede a los mismos.

\subsubsection{Análisis de ofertas}

Ecopetrol S.A. hará las comparaciones mediante el cotejo de los ofrecimientos recibidos y la consulta de precios y condiciones de mercado; además, considerará los resultados de las asesorías internas o externas que estime conveniente solicitar y aplicará los factores de evaluación que se hubieren establecido, de tal modo que se logren obtener conclusiones asociadas a dicha comparación, en desarrollo del método de elección.

El análisis de las ofertas será realizado por un comité o por el trabajador de Ecopetrol S.A. que designe el Funcionario Autorizado. Lo anterior, sin perjuicio de la posibilidad de contratar el desarrollo de esta actividad con un tercero. Los resultados del análisis pueden conducir a la celebración de un contrato o al desarrollo de una etapa de negociación.

El análisis de las ofertas se debe realizar teniendo en cuenta lo previsto en la documentación del método de elección y dentro del plazo que se haya señalado, el cual se podrá ampliar por el término que Ecopetrol S.A. estime necesario, en tanto las ofertas estén vigentes.

Todos los derechos reservados para Ecopetrol S.A. Ninguna reproducción externa copia o transmisión digital de esta publicación puede ser hecha sin permiso escrito. Ningún párrafo de esta publicación puede ser reproducido, copiado o transmitido digitalmente sin un consentimiento escrito o de acuerdo con las leyes que regulan los derechos de autor y con base en la regulación vigente. 


\begin{tabular}{|c|c|c|c|}
\hline & \multicolumn{3}{|c|}{ MANUAL DE CONTRATACIÓN DE ECOPETROL S.A. } \\
\hline & \multicolumn{3}{|c|}{$\begin{array}{l}\text { GESTIÓN DE ABASTECIMIENTO } \\
\text { VICEPRESIDENCIA JURÍDICA }\end{array}$} \\
\hline Fiat & $\begin{array}{c}\text { CODIGO } \\
\text { GAB-M-001 }\end{array}$ & $\begin{array}{c}\text { Elaborado } \\
20 / 12 / 2016\end{array}$ & Versión: 1 \\
\hline
\end{tabular}

4.5.5. Conclusiones sobre el método de elección

Las conclusiones se adoptarán dentro del plazo previsto y respetando la documentación del método de elección. El plazo se podrá ampliar en tanto las ofertas estén vigentes.

En todos los contratos a celebrar, la aceptación de la oferta y la consecuente decisión de contratar, se podrán efectuar a través de cualquier procedimiento comercial permitido, conforme al régimen jurídico aplicable.

Si el ofertante con quien se decide contratar o negociar no acepta dicha decisión y/o no suscribe el contrato dentro del término previsto en la documentación del método de elección, Ecopetrol S.A. podrá contratar o negociar con el ofertante calificado en segundo lugar, siempre y cuando su oferta fuere favorable para Ecopetrol S.A. y estuviere vigente a la fecha, para lo cual igualmente podrá aplicar procedimientos comerciales orientados a salvaguardar el ofrecimiento más acorde con los criterios establecidos por la compañía para hacerse a las mejores ofertas. Si éste tampoco suscribe el contrato o no negocia, dentro del plazo previsto en la comunicación respectiva, se aplicarán las mismas reglas con los siguientes ofertantes en el orden de elegibilidad o negociación, en tanto existan más ofertas favorables y sin perjuicio de la responsabilidad de indemnizar los posibles perjuicios inferidos a Ecopetrol S.A., y de hacer efectiva la garantía de seriedad de la oferta.

\subsubsection{Suspensión y Cancelación del método de elección}

Si existen razones objetivas que así lo justifiquen, el método de elección podrá ser suspendido o cancelado total o parcialmente. Esta decisión requiere de la respectiva justificación, del visto bueno del Funcionario Autorizado del nivel superior, y del respectivo Comité Asesor de Compras y Contratación, y será informada a los interesados u ofertantes.

\subsection{Perfeccionamiento}

A menos que la ley exigiere expresamente que se cumpla con determinada formalidad, el contrato se entiende perfeccionado cuando se acuerden sus elementos esenciales entre el Funcionario Autorizado de Ecopetrol S.A. y el contratista, o su representante legal.

Una vez perfeccionados, para efectos probatorios los contratos de Ecopetrol S.A. se consignarán en documento escrito.

\subsubsection{Gestión de Contratos}

La gestión de contratos en Ecopetrol S.A. se hará de forma diferenciada, atendiendo la complejidad del contrato, la criticidad del suministro, el desempeño y la experiencia del contratista. La gestión de contratos podrá variar entre supervisión alta con seguimiento en detalle de las actividades; media, de seguimiento aleatorio, o baja principalmente por autogestión del proveedor.

En la supervisión media y baja se deben definir alertas para variar el grado de supervisión, en caso de incumplimiento de obligaciones.

El objetivo del subproceso de gestión de contratos es asegurar el inicio, ejecución, cierre y balance de los contratos, realizando una adecuada gestión de eventualidades y haciendo la evaluación del desempeño del contratista.

Todos los derechos reservados para Ecopetrol S.A. Ninguna reproducción externa copia o transmisión digital de esta publicación puede ser hecha sin permiso escrito. Ningún párrafo de esta publicación puede ser reproducido, copiado o transmitido digitalmente
sin un consentimiento escrito o de acuerdo con las leyes que regulan los derechos de autor y con base en la regulación vigente. 


\begin{tabular}{|c|c|c|c|}
\hline \multirow{3}{*}{ : FeTROL } & \multicolumn{3}{|c|}{ MANUAL DE CONTRATACIÓN DE ECOPETROL S.A. } \\
\hline & \multicolumn{3}{|c|}{$\begin{array}{l}\text { GESTIÓN DE ABASTECIMIENTO } \\
\text { VICEPRESIDENCIA JURÍDICA }\end{array}$} \\
\hline & $\begin{array}{c}\text { CODIGO } \\
\text { GAB-M-001 } \\
\end{array}$ & $\begin{array}{c}\text { Elaborado } \\
20 / 12 / 2016 \\
\end{array}$ & Versión: 1 \\
\hline
\end{tabular}

El Administrador debe alistar su contrato para la ejecución, dando cumplimiento a los requisitos previstos para este efecto. Entre las actividades recurrentes durante la ejecución de contratos se destacan las siguientes:

a. Realizar reunión de inicio.

b. Cerciorarse y dejar documentado el recibo a satisfacción, para efectuar los pagos.

c. Evaluar periódicamente al contratista.

d. Hacer seguimiento teniendo en cuenta que en la ejecución contractual se coordine el avance del objeto del contrato, el tiempo restante de ejecución y los pagos efectuados frente al presupuesto planeado.

Las eventualidades se atenderán diligentemente en un plazo razonable, dejando documentado todas las aproximaciones que hagan las Partes para su solución y respetando las previsiones contractuales, entre otras, en relación con incumplimientos, sanciones, suspensiones, subcontratación y reclamos.

Es responsabilidad del Administrador del Contrato velar por la completitud de la información y documentación de la gestión del contrato en el archivo correspondiente.

\subsubsection{Variaciones en las condiciones de los contratos}

Los contratos en Ecopetrol S.A. deben preservarse especialmente en las condiciones de objeto, plazo y precio pactados, sin perjuicio de las variaciones en los casos en que se presenten situaciones que justifiquen de manera razonada y suficiente los cambios a los términos contractuales inicialmente pactados.

\subsubsection{Cláusula penal y multas}

Se pueden pactar en el contrato y cobrar al contratista las cláusulas penales y multas derivadas de la falta de cumplimiento parcial o total del contrato. Se podrán hacer uso de los mecanismos para su cobro pactados por las Partes, que sean acordes con el régimen jurídico aplicable a Ecopetrol S.A. EI contrato presta mérito ejecutivo, por sí solo, o mediante la conformación de un título ejecutivo complejo, siempre que contenga una obligación clara, expresa y exigible.

\subsubsection{Terminación del vínculo contractual}

Se pueden pactar en el contrato aquellos hechos que autoricen la terminación del vínculo contractual, siempre y cuando sea producto del libre consentimiento entre las Partes, se encuentre acorde con el régimen jurídico de Ecopetrol S.A., no se constituya en un acto de abuso del derecho o que se derive de conductas contrarias a la libre competencia.

\subsubsection{Cierre y balance de contratos}

Los contratos concluirán con la etapa de cierre, en la cual se hará un balance económico, financiero, técnico y operativo del contrato, se documentarán las eventualidades ocurridas y/o pendientes y se dejarán las observaciones que consideren las Partes. Dicho balance se plasmará en un documento.

Todos los derechos reservados para Ecopetrol S.A. Ninguna reproducción externa copia o transmisión digital de esta publicación puede ser hecha sin permiso escrito. Ningún párrafo de esta publicación puede ser reproducido, copiado o transmitido digitalmente sin un consentimiento escrito o de acuerdo con las leyes que regulan los derechos de autor y con base en la regulación vigente. 


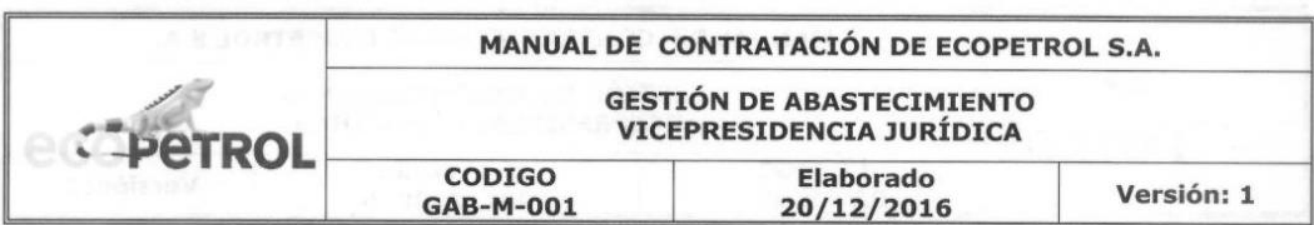

Las Partes bajo el principio de autonomía de la voluntad tienen capacidad para establecer y consentir en el documento de balance los acuerdos, conciliaciones y transacciones a que se llegue para poner fin a las divergencias presentadas y poder declararse en paz y salvo por las obligaciones asumidas en el respectivo contrato. Así mismo tienen el derecho de incluir las salvedades que a bien tengan y sobre aspectos no resueltos o solucionados entre las Partes.

Si el contratista no se presenta a la etapa de cierre o si a pesar de la libertad que tiene de dejar las observaciones o puntos de vista en el documento respectivo, no procede a firmarlo, Ecopetrol S.A. tiene la posibilidad de realizar un balance interno en las condiciones aquí estipuladas y para sus propios fines. Para efectos del balance final interno del contrato en Ecopetrol S.A., esta acta tiene valor de documento final de cierre contractual.

\subsection{Disposiciones Varias}

\subsubsection{Formalidades de los actos contractuales}

Los actos que se emitan o celebren con ocasión de la actividad contractual de Ecopetrol S.A., no constituyen actos administrativos, ni estarán sujetos a formalidades especiales, sin perjuicio de aquellas que exija la ley para su perfeccionamiento.

\subsubsection{Utilización de medios electrónicos}

En todos los trámites regulados en el presente Manual, se podrán utilizar los medios electrónicos, con el cumplimiento de los requisitos señalados en la ley de comercio electrónico y en las normas que la reglamenten, la modifiquen o complementen y de conformidad con las directrices internas de Ecopetrol S.A.

\subsubsection{Normas y procedimientos adicionales}

Ningún trabajador de Ecopetrol S.A. podrá dictar normas, controles, ni actuar con desconocimiento de los procedimientos previstos en el presente Manual.

\subsubsection{Legislación aplicable}

Los contratos que celebre Ecopetrol S.A. se regirán por la legislación especial que les sea aplicable, de conformidad con las disposiciones comerciales y civiles pertinentes.

Los contratos celebrados en el extranjero se podrán regir por las reglas del país en donde se hayan celebrado, a menos que se deban cumplir en Colombia.

En lo no previsto en este Manual y sin perjuicio de atender las disposiciones constitucionales y legales pertinentes, aplicarán las normas comerciales y civiles, las cuales se constituyen en el régimen jurídico contractual de Ecopetrol S.A.

\subsubsection{Vigencia}

El presente Manual de Contratación entrará a regir a partir del 2 de enero de 2017.

Todos los derechos reservados para Ecopetrol S.A. Ninguna reproducción externa copia o transmisión digital de esta publicación puede ser hecha sin permiso escrito. Ningún párrafo de esta publicación puede ser reproducido, copiado o transmitido digitalmente sin un consentimiento escrito o de acuerdo con las leyes que regulan los derechos de autor y con base en la regulación vigente. 


\begin{tabular}{|c|c|c|c|}
\hline \multirow{3}{*}{ "fPeTROL } & \multicolumn{3}{|c|}{ MANUAL DE CONTRATACIÓN DE ECOPETROL S.A. } \\
\hline & \multicolumn{3}{|c|}{$\begin{array}{l}\text { GESTIÓN DE ABASTECIMIENTO } \\
\text { VICEPRESIDENCIA JURÍDICA }\end{array}$} \\
\hline & $\begin{array}{c}\text { CODIGO } \\
\text { GAB-M-001 } \\
\end{array}$ & $\begin{array}{c}\text { Elaborado } \\
20 / 12 / 2016\end{array}$ & Versión: 1 \\
\hline
\end{tabular}

Los procesos de selección que se encuentren en curso con anterioridad a la entrada en vigor del presente Manual, así como los contratos en ejecución (incluyendo los contratos adicionales u otrosíes que se suscriban con posterioridad a la emisión del presente Manual) o en liquidación, seguirán rigiéndose por el Manual y por las normas vigentes al momento de la iniciación del proceso de contratación o de la suscripción del respectivo contrato o del contrato primigenio.

\subsubsection{Aprobación}

El presente Manual de Contratación se suscribe por el Presidente, teniendo en cuenta los lineamientos, fundamentos y autorizaciones aprobadas por la Junta Directiva de Ecopetrol S.A., según acta No 245 del 16 de septiembre de 2016 .

\section{CONTINGENCIAS}

No Aplica

\section{RELACIÓN DE VERSIONES}

\begin{tabular}{|c|c|c|c|}
\hline \multicolumn{4}{|c|}{ Documento Anterior } \\
\hline Versión & Fecha & Antiguo Código y Título & Cambios \\
\hline 1 & $15 / 10 / 2012$ & $\begin{array}{c}\text { GSJ-M-001 Manual de } \\
\text { Contratación de Ecopetrol } \\
\text { S.A. }\end{array}$ & Manual de Contratación de Ecopetrol S.A. \\
\hline \multicolumn{4}{|c|}{ Documento Nuevo } \\
\hline Versión & Fecha & & Cambios \\
\hline 1 & $20 / 12 / 2016$ & \multicolumn{2}{|c|}{$\begin{array}{l}\text { Terminología , procesos de contratación (modalidades de selección) y } \\
\text { etapas contractuales, nuevo código }\end{array}$} \\
\hline \multicolumn{4}{|c|}{$\begin{array}{l}\text { Para mayor información sobre este documento dirigirse a quien lo elaboró, en nombre de la } \\
\text { dependencia responsable: }\end{array}$} \\
\hline \multicolumn{4}{|c|}{$\begin{array}{l}\text { Elaboró: Diego Fernando Manrique Nieto } \\
\text { Teléfono: } 43246 \quad \text { Buzón: diego.manrique@ecopetrol.com.co } \\
\begin{array}{l}\text { Dependencia: Vicepresidencia Jurídica }\end{array}\end{array}$} \\
\hline
\end{tabular}

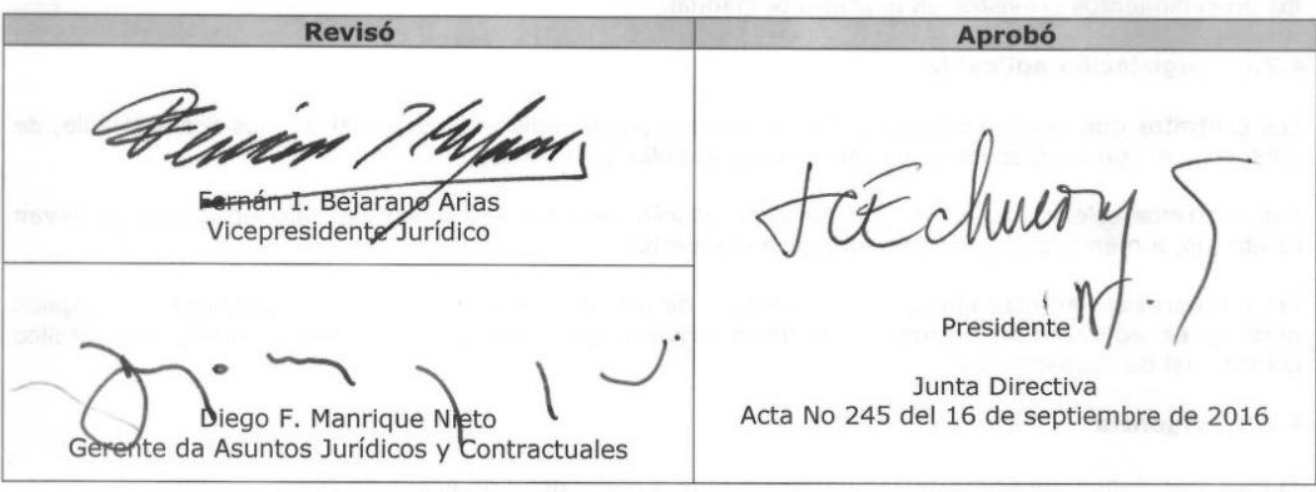

Todos los derechos reservados para Ecopetrol S.A. Ninguna reproducción externa copia o transmisión digital de esta publicación puede ser hecha sin permiso escrito. Ningún párrafo de esta publicación puede ser reproducido, copiado o transmitido digitalmente sin un consentimiento escrito o de acuerdo con las leyes que regulan los derechos de autor y con base en la regulación vigente. 
Apéndice B. Contrato MA-0018531

\author{
CONTRATO N MA-0018531
}

Contratantes o Partes: Son:

a) ECOPETROL S.A. (en adelante ECOPETROL S.A.), Sociedad de Economia Mixta, autorizada por la Ley 1118 de 2006, vinculada al Ministerio de Minas y Energía, que actúa conforme a sus estatutos y tiene su domicilio principal en Bogotá D.C., con NIT 899.999.068-1, representada por NELSON ORLANDO NEIRA ROJAS, identificado con la cédula de ciudadanía No. 11.407.690 expedida en Cáqueza Cundinamarca, quien actúa en su condición de Funcionario Autorizado Compras y Contratación Cadena Habilitadores, facultado para suscribir el presente Contrato de conformidad con lo dispuesto en el Manual de Delegaciones, y

b) UNIÓN TEMPORAL PLATAFORMAS PETROLERAS $X$, constituida según acuerdo suscrito el dos (02) de marzo de 2012, por: OBRAS Y DISENNOS S.A., sociedad constituida mediante Escritura Pública N ${ }^{\circ}$ 1698 del 12 de julio de 1990, otorgada en la Notaría 26 del Círculo Notarial de Bogotá D.C y con NIT N800.101.333-3, con domicilio principal en Bogotá D.C.; M.R. INGENIEROS LTDA., sociedad constituida mediante Escritura Pública $N^{\circ} 988$ del 26 de febrero de 1997, otorgada en la Notaria 03 del Círculo Notarial de Bucaramanga y con NIT N $804.004 .100-3$, con domicilio principal en Bucaramanga Santander; D. INGENIERIA LTDA, sociedad constituida mediante Escritura Pública $\mathrm{N}^{\circ} 1247 \mathrm{del} 09$ de junio de 1994, otorgada en la Notaría 08 del Círculo Notarial de Bucaramanga y con NIT N $^{\circ}$ 800.232.197-1, con domicilio principal en Bucaramanga - Santander; PETROLABIN LTDA., sociedad constituida mediante Escritura Pública $N^{\circ} 2621$ del 30 de octubre de 1990, otorgada en la Notaria 06 del Círculo Notarial de Bucaramanga y con NIT N $800.113 .677-3$, con domicilio principal en Bucaramanga Santander; CESAR AUGUSTO DUARTE GARZÓN., Persona Natural, mayor de edad, identificado con cédula de ciudadania $\mathrm{N}^{\circ}$ 91.245.485 expedida en Bucaramanga (Santander), y con NIT N91.245.485-1, con domicilio principal en Bucaramanga (Santander); Unión Temporal que para los efectos de este acto se denomina el CONTRATISTA, representado por CARLOS AUGUSTO RAMIREZ GOMEZ, mayor de edad, vecino de la ciudad de Bogotá, identificado con la cédula de ciudadania $N^{\circ} 16.216 .649$ expedida en Cartago Valle.

El Representante Legal del CONTRATISTA manifiesta que ni él ni la Unión Temporal que representa se encuentran incursos en causal alguna de inhabilidad o incompatibilidad previstas en la Constitución Politica o en la ley que impida la celebración de este Contrato.

En las condiciones anotadas, ECOPETROL y el CONTRATISTA hacen constar, por el presente documento, que han celebrado un Contrato, previas las siguientes,

\section{CONSIDERACIONES:}

a) ECOPETROL tramitó el PS No. 50003365 con el propósito de contratar "CONTRATOS MARCO PARA MONTAJE Y CONSTRUCCION DE FACILIDADES DE SUPERFICIE PARA PROYECTOS DE PRODUCCION Y EXPLORACIÓN A NIVEL NACIONAL Y CAMPOS MENORES ASOCIADOS A LA GERENCIA".

b) UNIÓN TEMPORAL PLATAFORMAS PETROLERAS X, presentó propuesta en el PS mencionado, la cual fue evaluada de conformidad con las reglas previstas al respecto en los DPS.

c) El día 01 de octubre de 2012, ECOPETROL aceptó la propuesta presentada por UNIÓN TEMPORAL PLATAFORMAS PETROLERAS $X$, por constituir el ofrecimiento más favorable.

d) EI CONTRATISTA cumplió todo lo que según la normatividad vigente debia cumplir y acreditar y aportar antes de suscribir este Contrato, de conformidad con lo exigido en este documento.

e) El CONTRATISTA dará estricto cumplimiento a todas las obligaciones establecidas en este Contrato y en los DPS, asi como a lo ofrecido en la propuesta con la cual participó en el PS. Adicionalmente, el CONTRATISTA se obliga a ejecutar el presente Contrato de buena fe, de conformidad con el arýculo 1603 del Código Civil; por consiguiente, se obliga no sólo a lo que en el Contrato se expresa, sino a todas las cosas que emanan precisamente de la naturaleza de las diferentes obligaciones pactadas en el mismo, o que por la ley pertenezcan a ella. En concordancia con lo anterior, a este Contrato le aplican 


\section{CONTRATO NMA-0018531}

\section{ecroterrol}

todas las disposiciones legales vigentes, por lo que las Partes se obligan a cumplirlas independientemente de que se consignen o no en este documento.

Con fundamento en lo anterior, LAS PARTES suscriben el Contrato que obra en las siguientes Cláusulas:

\section{CLÁUSULA PRIMERA.-OBJETO DEL CONTRATO}

EI CONTRATISTA, de manera oportuna y diligente, en forma independiente, con personal propio, obrando con plena autonomía administrativa, técnica, directiva y financiera, se obliga a favor de ECOPETROL S.A. a prestar los servicios de:

"CONTRATO MARCO PARA MONTAJE Y CONSTRUCCION DE FACILIDADES DE SUPERFICIE PARA PROYECTOS DE PRODUCCION Y EXPLORACIÓN EN LA GCO Y CAMPOS MENORES ASOCIADOS A ESTA GERENCIA" según el anexo 47 y bajo las condiciones técnicas previstas en los Anexos 7 al 7.5 de los
DPS.

Por ser el presente un contrato marco, las obras y servicios especificos que deberá ejecutar el CONTRATISTA, y las condiciones de tiempo, modo, lugar y otras caracteristicas de cada una de las labores serán comunicadas a través de ÓRDENES DE TRABAJO suscritas por un representante de ECOPETROL S.A. Tales órdenes estarán sujetas a las condiciones generales del presente Contrato y el CONTRATISTA se obliga desde ya a ejecutarlas cumpliendo oportunamente todo lo establecido en el presente contrato y en cada
una de las órdenes.

EI CONTRATISTA deberá tener en cuenta todas las obras y labores necesarias para el cabal cumplimiento del alcance contractual, sin que la ejecución de las mismas implique un incremento en las tarifas o en el precio establecido en el presente Contrato.

PARÁGRAFO PRIMERO: En desarrollo del presente CONTRATO, EL CONTRATISTA se compromete a no dar curso a órdenes que traten sobre temas, cantidades o conceptos adicionales a lo previsto en el presente CONTRATO ni a presentar facturación adicional por conceptos no contenidos expresamente en el alcance contractual, salvo la mediación de un documento adicional debidamente suscrito por los representantes competentes de ambas partes. Cualquier trabajo que realice por fuera del marco descrito anteriormente correrá por cuenta y riesgo de EL CONTRATISTA únicamente y no será cobrado a ECOPETROL S.A.

PARAGRAFO SEGUNDO: EL CONTRATISTA se compromete a buscar y sugerir oportunidades de mejora en el desarrollo de las obras, cuando técnica y económicamente beneficien a ECOPETROL. S.A., sin que ello
genere obligación alguna para ECOPETROL S.A.

PARÁGRAFO TERCERO: EI CONTRATISTA declara que el trabajo se llevará a cabo diligente y eficientemente, de una manera segura y de forma oportuna, de acuerdo con los estándares y especificaciones contenidas en este Contrato o sus anexos. EI CONTRATISTA cumplirá con cualquier instrucción o directriz escrita emitida por el funcionario competente de ECOPETROL S.A. con respecto a cuatquior o directriz considerado bajo esta cláusula o este Contrato.

PARÁGRAFO CUARTO: EI CONTRATISTA declara que conoce, entiende y acepta las condiciones técnicas previstas tanto en este instrumento como en sus anexos y soportes. La ejecución del Contrato bajo condiciones técnicas distintas o diferentes a las previstas en este documento o sus anexos, serán consideradas como incumplimiento de las obligaciones a cargo en este documento o sus anexos, serán bajo condiciones técnicas más gravosas para ECOPETROL incumplimiento de las obligaciones presentará facturación, solicitud a cargo del CONTRATISTA. EI CONTRATISTA manifiesta que no ejecución del Contrato acuda a condiciones técnición o demanda contra ECOPETROL. S.A., cuando en la este instrumento $o$ en sus anexos o soportes. 
CONTRATO N MA-0018531

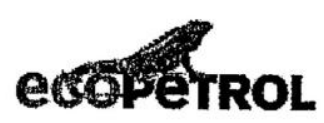

\section{CLAUUSULA SEGUNDA - GENERALIDADES DE LA ORDEN DE TRABAJO}

La orden de trabajo tendrá previsto, entre otros aspectos los siguientes:

- Lugar preciso asignado para la prestación del servicio o ejecución de las obras, en el área de Ejecución del Contrato.

Cronograma detallado de servicios u obras, especificando las fechas de inicio, período de ejecución y fecha de terminación.

En desarrollo del presente contrato el CONTRATISTA deberá involucrar como parte de las labores que debe realizar la entrega de un Plan Detallado de Trabajo - PDT por cada orden de trabajo asignada, el cual será revisado por ECOPETROL S.A. y con el se efectuará por las partes el seguimiento y control a la ejecución.

En desarrollo del presente contrato el CONTRATISTA deberá involucrar como parte de las labores que debe realizar la entrega de un PDT por obra a ejecutar y los siguientes informes:

REPORTE SEMANAL DE ACTIVIDADES Y AVANCE DEL PROYECTO. EI CONTRATISTA deberá contemplar la ejecución de un informe semanal de actividades y de acuerdo al formato establecido por ECOPETROL S.A. durante la ejecución del contrato en donde se establezcan las actividades realizadas y se indique la gestión en cumplimiento del contrato. El informe debe incluir la curva " $\mathrm{S}$ " del proyecto con el avance real semanal de las actividades VS el programado semanal o curva planeada en las herramientas, servidores y/o formatos definidos por ECOPETROL S.A. Asl mismo deberá levantar on planos las modificaciones a que diera lugar cualquier actividad ejecutada dentro del contrato. El informe semanal deberá involucrar:

- Actividades diarias descritas en orden cronológica realizadas durante la semana

- Actividades detalladas de la semana siguiente

- Observaciones

- Porcentaje de avance programado

- Porcentaje de avance real

- Porcentaje acumulado ejecutado

- Dias de atraso ò adelanto

- Personal y maquinaria utilizados en la orden de trabajo

- Registro fotográfico de las obras ejecutadas

La construcción de las obras objeto de cada orden de trabajo del presente contrato deberá cumplir con lo establecido en el diseño, que en su momento sea entregado al CONTRATISTA por ECOPETROL S.A. asi como las acciones para cumplir con los programas de trabajo establecidos.

REPORTE MENSUAL Y TRIMESTRAL POR ORDEN DE TRABAJO. EI CONTRATISTA deberá contemplar la ejecución de un informe mensual y trimestral de actividades en donde se establezcan las actividades realizadas y se indique la gestión en cumplimiento del Contrato.

\section{CLÁUSULA TERCERA.-PLAZOS DEL CONTRATO}

La vigencia del Contrato se iniciará a partir de su perfeccionamiento, y comprenderá el plazo de ejecución y el de liquidación.

El plazo de ejecución de este Contrato es de veinte (20) meses o hasta el treinta y uno (31) de diciembre de dos mil trece (2013), o lo que primero ocurra, que se contabilizarán a partir de la fecha de suscripción del Acta de Inicio o de la fecha que en ésta se indique.

El plazo de liquidación de mutuo acuerdo del Contrato es de cuatro (4) meses contados desde la fecha de finalización del plazo de ejecución o desde la fecha de terminación de la ejecución por cualquier otra causa; y el plazo de liquidación unilateral es de dos (2) meses contados desde el vencimiento del plazo previsto para l liquidación de mutuo acuerdo. ECOPETROL S.A queda expresamente facultada para realizar la liquidación té manera unilateral, en caso de que no fuere posible realizaria de mutuo acuerdo dentro del plazo señalado para el fecto. Las ordenes de trabajo deberán ser liquidadas independientemente y en los mismos plazos (4 meses bilateral y 2 meses unilateral posteriores al vencimiento de la bilateral) 
La ampliación del plazo de ejecución o del de liquidación sólo se podrá realizar mediante acuerdo de voluntades de las Partes, y siempre y cuando aquel(los) se encuentre(n) vigente(s).

\section{CLÁUSULA CUARTA - VALOR DEL CONTRATO}

El valor acordado del presente Contrato es indeterminado y su valor final será aquel que resulte de multiplicar los precios unitarios contenidos en el Cuadro de precios señalado en el presente Contrato por las cantidades de obra y/o servicios efectivamente ejecutados ANEXO No. 1 CUADRO DE CANTIDADES Y PRECIOS, que dieron lugar a la asignación del presente Contrato.

Los precios unitarios contenidos en la Propuesta del CONTRATISTA señalados en la presente cláusula, no sufrirán modificación alguna durante la ejecución del contrato, diferente a los ajustes previstos en este mismo Contrato, de tal manera que la Propuesta en los términos presentados a ECOPETROL S.A. se mantendrá vigente en todo su contenido hasta el momento en que se dé cabal y definifivo cumplimiento a su ejecución.

EI Valor ofertado por el CONTRATISTA y aceptado por ECOPETROL en el presente contrato incluye el total de costos requeridos para la ejecución del contrato, que entre otros incluyen los siguientes: costo del material y equipos requeridos, costo de transporte del personal, materiales y equipos hasta y desde el sitio de la obra costo del personal que sea necesario en el Lugar de Ejecución, costos inherentes a pruebas, costos de CONTRATISTA relacionados con salarios del personal, prestaciones sociales deberán considerar los beneficios convencionales (contemplados en la convención colectiva del trabajo USO - ECOPETROL 200 2014 y sus actos que la adicionen y/o modifiquen y que se encuentren vigentes a la fecha de presentación de la propuesta, y el valor del seguro colectivo de vida de condiciones USO y demás derechos laborales; costo de primas de las pólizas de seguro, todos los costos por administración, imprevistos y utilidades del CONTRATISTA y todo concepto relativo a impuestos de cualquier indole, directos o indirectos.

Únicamente se reconocerán reajustes salariales al Contrato cuando ECOPETROL modifique los salarios establecido para el régimen salarial convencional, al cual tienen derecho los trabajadores que laboren durante su ejecución y que no hayan sido previsibles al momento de la presentación de la oferta. En este caso ECOPETROL comunicará por escrito al CONTRATISTA el aumento correspondiente y la fecha a partir de la cual se hará efectivo y deberá calcularse el reajuste salarial.

Procedimiento:

El costo directo de la mano de obra involucrada en la ejecución de los ítems de cada acta parcial se reajustará aplicándole al salario base, a las prestaciones sociales y a los aportes al sistema de seguridad social integral los incrementos que se produzcan por directriz de ECOPETROL, en la proporción de tenga que asumir el CONTRATISTA en su calidad de empleador.

EI CONTRATISTA pagará los montos que de dicha liquidación se deriven directamente a los trabajadores, al igual que las obligaciones de seguridad social y aportes parafiscales.

El valor total del reajuste de cada acta parcial a reconocer al CONTRATISTA, corresponderá al obtenido a través de la siguiente fórmula:

$V=A^{*}\left[K+\left(m^{*}(1+P)\right)\right]$

Donde:

V: Valor del acta parcial reajustada (en su Costo Directo)

A: Valor del acta parcial objeto de reajuste (Solo costo Directo)

K: Porcentaje que representa la maquinaria, herramienta, equipos y materiales sobre el valor del contrato, el cual no debe ser mayor a $(100-m) \%$.

m: Porcentaje que representa la mano de obra sobre el valor del acta parcial de pago por especialidad del contrato, asi: mc: Porcentaje que representa la mano de obra de especialidad civil, el cual no debe ser mayor al
$17 \%$ 


\section{CONTRATO N MA-0018531}

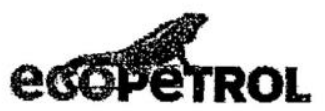

$\mathrm{mm}$ : Porcentaje que representa la mano de obra de especialidad mecánica, el cual no debe ser mayor al $37 \%$.

mi: Porcentaje que representa la mano de obra de especialidad instrumentación, el cual no debe ser mayor al $28 \%$

me: Porcentaje que representa la mano de obra de especialidad eléctrica, el cual no debe ser mayor al $22 \%$.

P: Porcentaje de reajuste indicado por ECOPETROL

El reajuste de acta parcial cubrirá todas las incidencias salariales que el CONTRATISTA esté obligado a pagar por razón del reajuste salarial y no tendrá derecho a ningún pago adicional por este concepto. No serán variables los rendimientos, el porcentaje de AlU pactado en el contrato, ni otros costos requeridos para la ejecución del mismo, argumentando que son función de la mano de obra.

En consecuencia, los reajustes, en las condiciones aquí previstas, se reconocen para la conservación del equilibrio financiero del Contrato y, por consiguiente, ECOPETROL no reconocerá suma diferente alguna por este concepto.

Respecto a la formula se precisa:

1. Aplica para salario no propios de la industria y salario propios de la industria o convencional.

2. Es aplicable siempre y cuando no se modifiquen las escalas salariales, es decir, que haya variaciones a los componentes o cargos de las escalas establecidas en las tablas en ambos regimenes y se aplique el mismo porcentaje de reajuste a todas ellas.

3. Que para ordenes integrales o conjuntas, es decir, aquellas que posean más de una especialidad, el acta parcial a reajustar deberá disgregarse por especialidad a facturar y poder aplicar la formula de manera independiente para cada especialidad y computar el valor total del acta reajustada.

ECOPETROL S.A., no realizará reajustes por concepto de MATERIALES Y EQUIPOS. Por to anterior, el CONTRATISTA debe asumir to referente a MATERIALES Y EQUIPOS durante las vigencias del Contrato (incluidas las prorrogas que de mutuo acuerdo se pacten), y se entiende incluido en el valor de la propuesta presentada por él.

ECOPETROL S.A. no se compromete a ordenar la ejecución de un máximo ni un mínimo de las obras o servicios antes señalados. Las cantidades finales serán las que correspondan a las órdenes de servicio emitidas por ECOPETROL S.A. y satisfactoriamente ejecutadas por el CONTRATISTA.

PARÁGRAFO PRIMERO: DESPLAZAMIENTOS DE PERSONAL DEL CONTRATISTA.- El costo de desplazamiento dentro del área de cobertura del contrato será asumido por el CONTRATISTA y se entiende incluido en el valor de la propuesta presențada por él.

PARÁGRAFO SEGUNDO: REAJUSTES.- ECOPETROL S.A. no despachará favorablemente reclamos o solicitudes de reajuste efectuadas por el CONTRATISTA, por concepto de costos, gastos, actividades o suministros adicionales que aquel requiera para ejecutar el Contrato, y que fueran previsibles al tiempo de presentación de su propuesta.

PARÁGRAFO TERCERO: La fórmula de reajuste de la presente clausula tendrá aplicabilidad para las actividades propias de la industria a partir del 1 de julio de 2013 y para las demás actividades a partir del 1 de enero de 2013.

\section{CLÁUSULA QUINTA.-FORMA DE PAGO}

ECOPETROL pagará mensualmente al CONTRATISTA el valor de las órdenes de trabajo asignadas en desarrollo del Contrato por avance ejecutado de trabajo y/o conforme al cumplimiento de los hitos contractuales definidos en cada orden de Trabajo, en Colombia, en PESOS COLOMBIANOS

Dicha suma será cancelada así:

5.1 PAGOS DE ORDENES DE TRABAJO 
CONTRATO N MA-0018531 $^{\circ}$

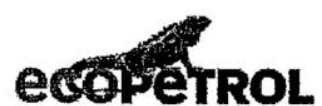

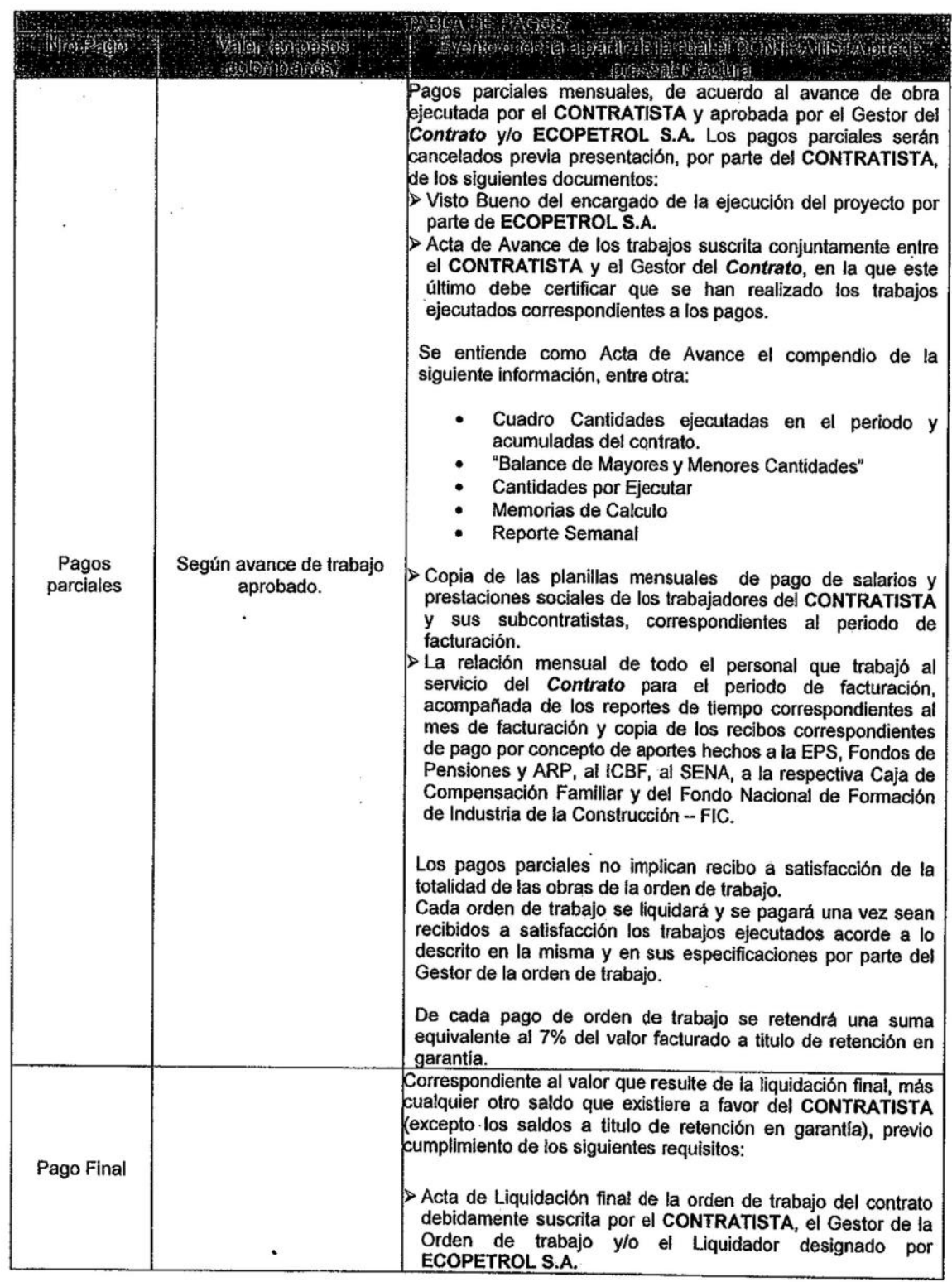




\section{CONTRATO N MA-0018531}

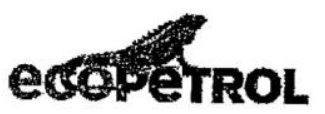

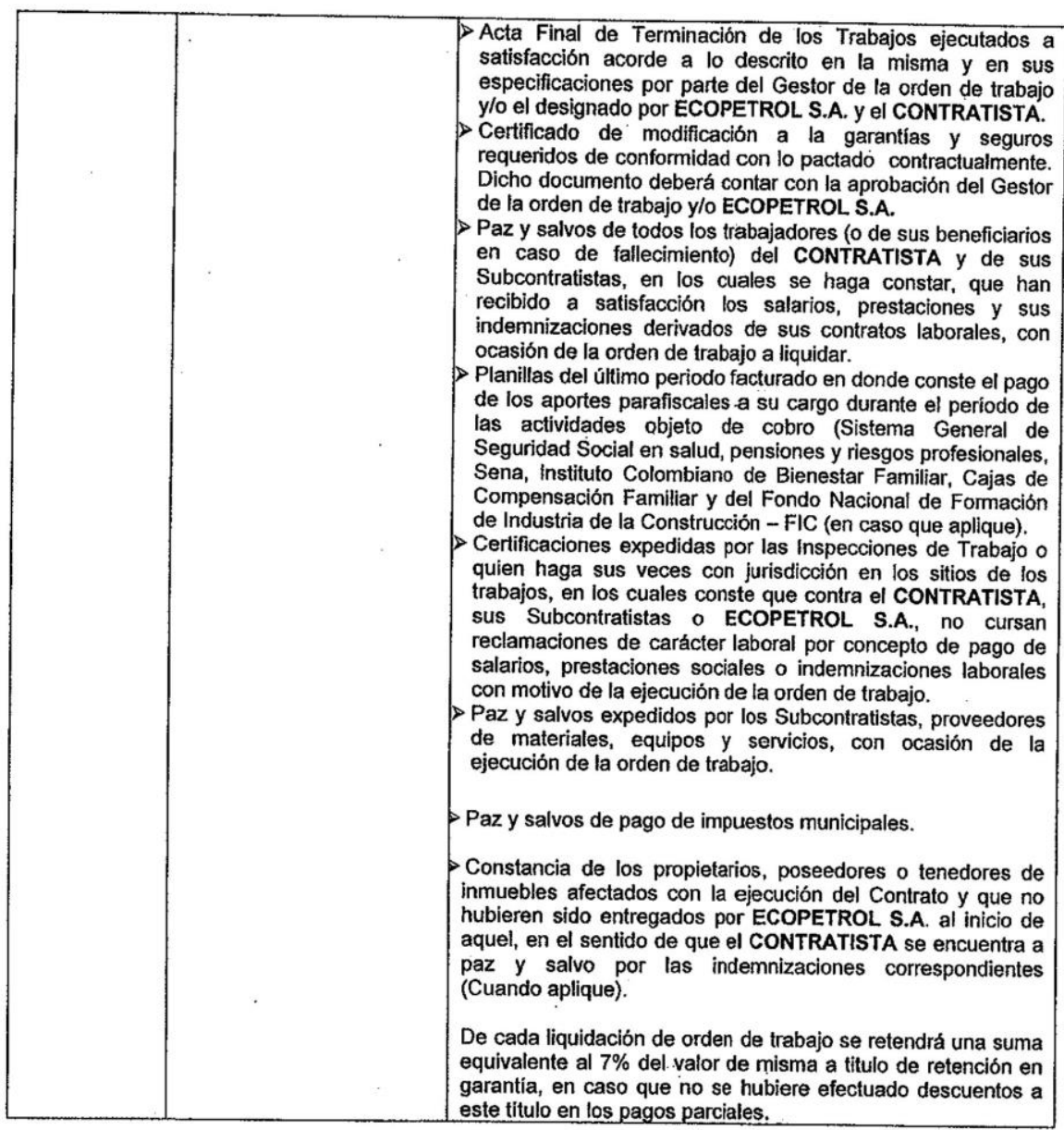

4.2 LIQUIDACION FINAL DEL CONTRATO

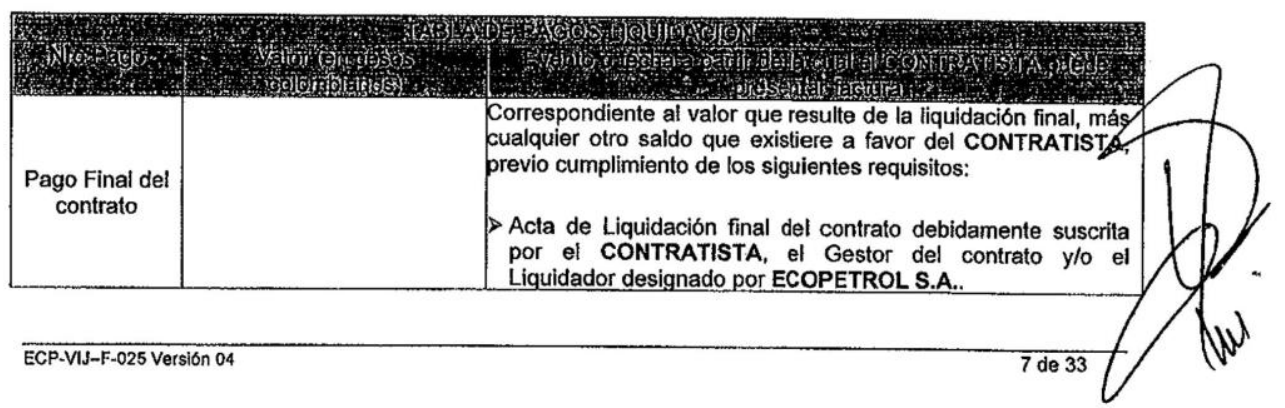




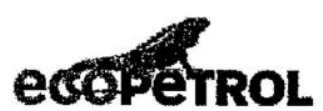

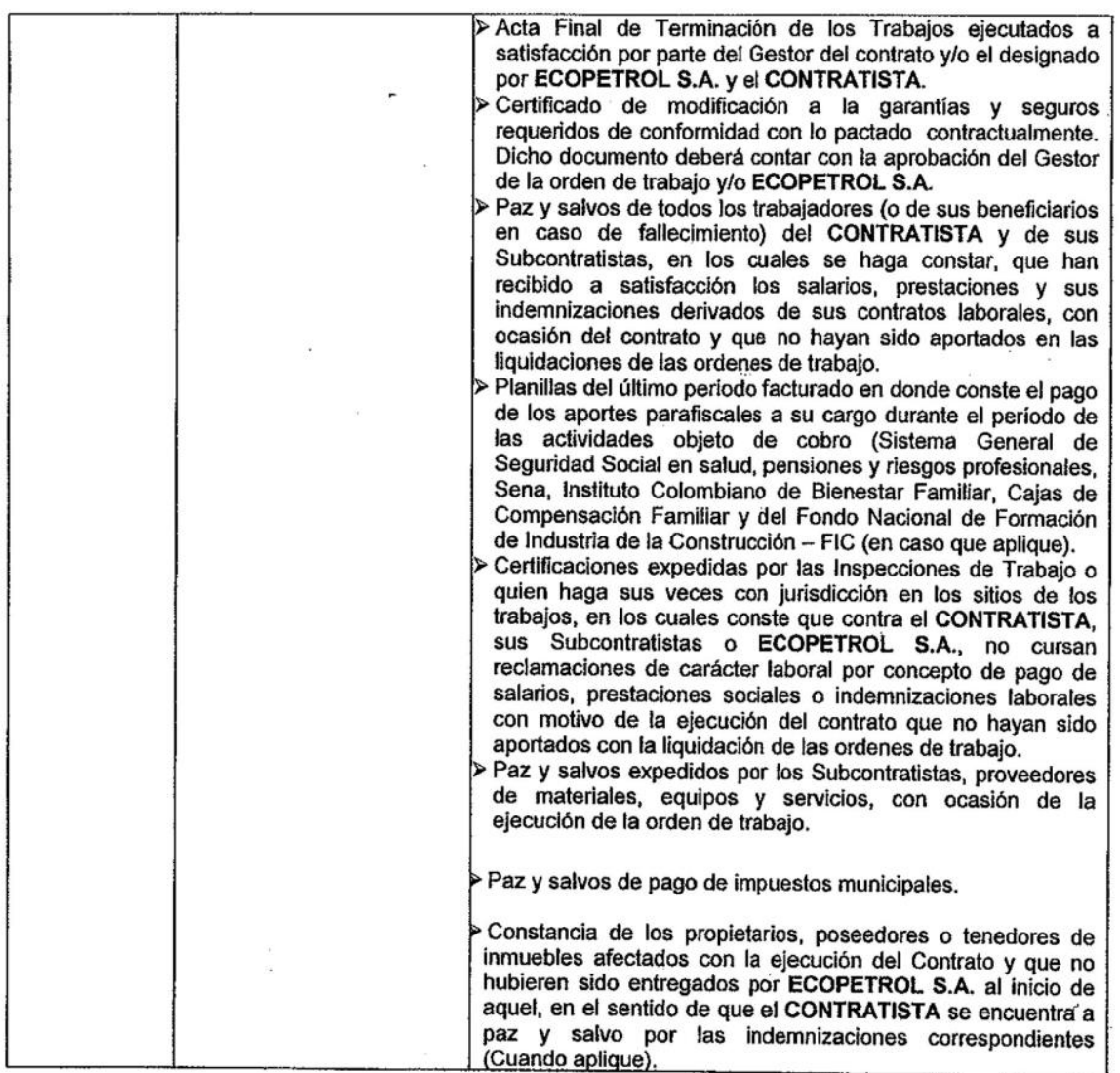

EI CONTRATISTA deberá presentar la factura en las oficinas de Cuentas por Pagar de ECOPETROL S.A. en Bogotá o las oficinas autorizadas para ello, dentro de los cinco (5) primeros días hábiles del mes siguiente al mes en que ejecutó las actividades o suministros que está facturando, excepto en el caso que se pacte contra pago de entregables, caso en el cual el CONTRATISTA deberá presentar la factura dentro de los quince (15) dias calendario siguientes al recibo a satisfacción de los mismos por parte de ECOPETROL L. El incumplimiento de esta obligación afectará la evaluación de desempeño del CONTRATISTA. mismo término el CONTRATISTA deberá entregar al Gestor del Contrato, copia de las planillas de pago de salarios y prestaciones sociales a los trabajadores del CONTRATISTA que tengan contrato laboral sometido a ley colombiana (este requisito no aplica en caso de que ECOPETROL S.A. aplique lo consignado en el Parágrafo de la Cláusula relativa a "Personal")

Los pagos sólo se realizarán si el CONTRATISTA ha realizado las actividades y entregado a satisfacción de ECOPETROL S.A. los informes, documentos u otros entregables que debiera haber presentado dentro del periodo que está facturando. 


\section{CONTRATO N MA-0018531}

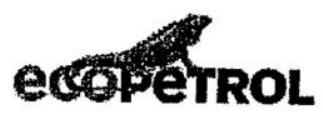

ECOPETROL S.A. efectuará los pagos a que haya lugar a los treinta $(30)$ dias calendarios siguientes a la fecha de radicación de la factura correspondiente por parte del CONTRATISTA, y previo el cumplimiento de los requisitos establecidos para ello.

Para que el CONTRATISTA pueda radicar la factura en los sitios indicados, el Gestor del Contrato deberá asegurar que previamente se ha cumplido con los requisitos previstos para el trámite de pagos.

La factura se deberá ajustar a la normatividad que le sea aplicable, y para efectos de pago se deberá presentar el original de la misma; ECOPETROL S.A. le dará trámite para pago siempre y cuando en el texto de la misma se indique:

1. El número de aprobación de la entrada de servicio o recibo (información que debe ser suministrada por el Gestor Administrativo)

2. El número del Contrato (pedido).

3. El valor de descuento del anticipo (si aplica), según el plan de descuento previsto en el Contrato.

4. Si existen cesiones o endosos autorizados por ECOPETROL S.A.: se deberá incluir la nota de traspaso del crédito, firmada por el cedente o endosante.

Adicionalmente, y en caso de que el Contrato se haya pactado por precios unitarios o tarifas, se deberá informar en la factura o en documento anexo a la misma, la cantidad de entregables / recursos / servicios / insumos / bienes a cobrar, con los correspondientes precios unitarios pactados para / resultado la sumatoria de todos los conceptos anteriores.

Todos los documentos y entregables requisito para la presentación de la factura deberán contar con la aprobación del Gestor (Administrativo y/o Técnico) designado por ECOPETROL S.A., de acuerdo con lo establecido en el procedimiento de coordinación del presente Contrato. Sin el cumplimiento de tales requisitos, la factura respectiva se tendrá como no presentada.

ECOPETROL S.A. revisará cada factura y le efectuará observaciones (si hubiere lugar a ello) por escrito dentro de los diez (10) dias calendario siguientes a la radicación de aquella. En caso de que no formulare observaciones dentro de dicho plazo, la factura se entenderá aceptada, recayendo la responsabilidad pertinente sobre el Gestor del Contrato.

PARÁGRAFO PRIMERO: Los errores aritméticos en las liquidaciones parciales presentadas por el CONTRATISTA serán susceptibles de corrección en cualquier tiempo, hasta la liquidiación final del por el Los reconocimientos o descuentos a que haya lugar se realizarán en el acta de liquidación final o mediante actas de aclaración.

Si las facturas no han sido bien elaboradas y no es posible su corrección por parte de ECOPETROL S.A., no se acompañan a ellas los documentos que para cada caso se solicitan en este Contrato, los plazos para que ECOPETROL. S.A. efectúe los pagos sólo se empezarán a contar desde la fecha en que quede corregida la factura o desde aquella en que se haya aportado el último de los documentos que debian acompañarla.

Todas las demoras que se presenten por estos conceptos serán de responsabilidad del CONTRATISTA quien por ello no tendrá derecho al pago de intereses o compensación de ninguna naturaleza.

PARÁGRAFO SEGUNDO: Los pagos parciales no implican el recibo o aprobación definitiva por parte de ECOPETROL S.A. de las actividades ejecutadas, bienes suministrados, productos entregados y, por consiguiente, no eximen al CONTRATISTA de su responsabilidad en cuanto a la calidad de los mismos o de cualquier otra obligación contractual o de responsabilidad civil.

PARÁGRAFO TERCERO: ECOPETROL S.A. efectuará, sobre cada factura, las retenciones que por ley esté autorizada a hacer, $y$ las deducciones y/o descuentos a que haya lugar.

PARÁGRAFO CUARTO: RECONOCIMIENTOS ECONÓMICOS A FAVOR DEL. CONTRATISTA. por razones ajenas a la responsabilidad del CONTRATISTA y/o subcontratistas, diferentes a aquellas generadas por factores climáticos (liuvias, crecientes de rios, etc.), los trabajos de culauier frente de obra se 
CONTRATO N MA-0018531

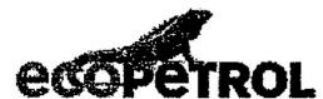

vean paralizados, ECOPETROL S.A. eventualmente y dependiendo de la imputabilidad de la causal que origina dicha parálisis, de acuerdo a la legislación aplicable, podrá hacer un reconocimiento económico al CONTRATISTA, correspondiente exclusivamente al costo directo de personal (no se incluye personal de administración) y maquinaria que se vea directamente involucrado en la paralización.

Se entienden como causas de paralizaciones imputables al CONTRATISTA y/o sus subcontratistas, entre otras, las siguientes:

- Existencia de acreencias laborales y/o comerciales del CONTRATISTA y/o sus subcontratistas y/o sus respectivos suministradores de servicios.

- El no pago de aportes al Sistema de Protección Social del CONTRATISTA y/o sus subcontratistas dentro de los términos señalados por la ley.

- Afectación por parte del CONTRATISTA y/o sus subcontratistas de áreas de trabajo diferentes a las indicadas por ECOPETROLS.A. y/o el Gestor del Contrato para la realización de los trabajos.

- La no atención oportuna de una orden de servicio programada por ECOPETROL y/o el Gestor de Contrato.

- La no realización oportuna de trabajos de conservación y mantenimiento de las vías de acceso utilizadas por el CONTRATISTA y sus subcontratistas, cuando tales trabajos estén dentro del alcance del contrato.

- La no disponibilidad de recursos de personal, maquinaria y material requeridos para el desarrollo de las actividades programadas en una determinada obra o frente de trabajo.

- Paralizaciones originadas en el incumplimiento de obligaciones comerciales; laborales o compromisos formales del CONTRATISTA y/o sus subcontratistas y/o sus suministradores de servicios, o con la comunidad.

- Las derivadas de la inobservancia de los lineamientos de indole social del área y de aquellas que se plasman en el RSE de ECOPETROL.

La valorización de los reconocimientos económicos a realizar por parte de ECOPETROL S.A., no involucrará ningún factor de actualización del dinero.

Con base en los reportes diarios de actividad o anotaciones de bitácora suscritos conjuntamente por el CONTRATISTA y el Gestor del Contrato, se establecen los recursos de maquinaria y personal directamente afectados por la paralización, entendiendo estos como aquellos que hayan presentado inactividad durante el periodo de stand by. No se efectuarán reconocimientos sobre maquinaria y personal que no estén reportes señalados. En los eventos en que los reportes no hayan sido suscritos conjuntamente, prevalecerá el que la Gestoria emita.

Para efectos de la valorización del reconocimiento económico a realizar por parte de ECOPETROL S.A., se procederá de la siguiente manera: (i) a los recursos de personal se les aplicarán las tarifas unitarias de acuerdo a los costos de las planillas de pago de dicho personal (ii) para los equipos que tengan tarifa unitaria pactada en el Contrato, se les aplicará dicha tarifa (no se entenderá como tarifa pactada en contrato la que figure como valor de hora adicional de equipo); para los equipos que no tengan tarifa unitaria pactada en Contrato, se aplicará el veinte por ciento $(20 \%)$ de la tarifa horaria de la Cámara Colombiana de la infraestructura vigentes al momento del stand by,

El reconocimiento del personal se efectuará sobre un máximo de 8 horas diarias, 48 semanales.

El reconocimiento del maquinaria y equipo se efectuará sobre un máximo de 5 horas diarias, 25 semanales. Para aquellos equipos que no tengan tarifa unitaria pactada en el Contrato, o no tengan tarifa en la Cámara Colombiana de la infraestructura, no habrá reconocimiento alguno.

Los equipos varados o en reparación, aunque se encuentren involucrados en el reporte diario de actividad, no se consideran para efectos de la valoración del reconocimiento económico a realizar por parte de ECOPETROL S.A. Tampoco se realizará reconocimiento cuando el personal y maquinaria sean utilizados en reprogramación de actividades.

De otro lado el CONTRATISTA, al momento de estimar los recursos que deberá involucrar para el desarrollo de los trabajos, debió tener en cuenta que los rendimientos de ejecución de las actividades que involucra el alcance del Contrato, se pueden ver afectados por altos períodos de lluvia que se registren dentro del plazo contractual y otros factores imprevistos. En consecuencia, el CONTRATISTA involucró en los costos de su propuesta, todos aquellos recursos adicionales que deban implementarse durante el desarrollo de los 
CONTRATO N MA-0018531

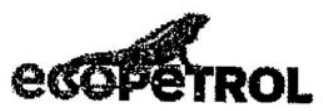

trabajos, a efecto de cumplir con el objeto del Contrato, dentro del plazo contractual. Aclarando que ECOPETROL no efectuará reconocimientos soportados en presuntas disminución de rendimientos.

PARAGRAFO QUINTO. RETENCIÓN EN GARANTÍA: Con el único objetivo de administrar los valores que en pesos colombianos y conforme a la Cláusula de Forma de Pago retenga ECOPETROL valores que Retención en Garantía, el CONTRATISTA compańía financiera debidamente autorizada por la Superintendencia Financiera; lo anterior deberá ser acreditado por el CONTRATISTA dentro de los veinte (20) dias calendario siguientes a la firma del Contrato.

En el contrato de fiducia mercantil, que deberá ser aprobado por el Gestor Administrativo, se incorporarán todas las observaciones de administración y manejo de recursos, según las previsiones establecidas en este Contrato y las que señale ECOPETROL. Adicionalmente, en él se hará constar que el CONTRATISTA este de manera incondicional el valor total de las retenciones on (patrimonio autónomo), y que cualquier desembolso con cargo al patrimonio autónomo lebe ser autorizado previamente por el Administrador del Contrato.

Todos los costos que demande la constitución y administración del contrato de fiducia mercantil serán por cuenta del CONTRATISTA.

Los valores que conforme a la Cláusula sobre Forma de Pago se retengan por este concepto y se giren a la fiduciaria se entienden como saldos a favor del CONTRATISTA, a quien corresponderán igualmente los rendimientos que se generen.

No obstante lo anterior, el valor que conformará el patrimonio autónomo, no podrá ser entregado por la sociedad fiduciaria al CONTRATISTA o a terceros, hasta tanto ECOPETROL de manera expresa lo autorice por escrito, previo el cumplimiento de los requisitos que se establecen para el pago final. ECOPETROL podrá disponer libremente de los dineros que se depositen en el patrimonio autónomo, para realizar pagos o atender obligaciones económicas a cargo del CONTRATISTA derivadas de la ejecución del presente Contrato, conforme a las estipulaciones contenidas en el mismo, por lo que en el contrato de fiducia mercantil deberán figurar como beneficiarios además del CONTRATISTA. a ECOPETROL para ordenar en cualquier momento a lo terceros (relacionados con obligaciones económicas a cargo del CONTRATISTA derivadas de la ejecución del presente Contrato) con cargo a los recursos depositados en la fiducia mercantil. Será obligación incondicional que no se autorice entregar al CONTRATISTA, una vez exista orden escrita para ello por parte de ECOPETROL.

Se aclara que de no existir reclamaciones ni cifras imputables a la retegarantia, cada seis meses contados a partir de la emisión de la primera orden de trabajo se realizará el análisis del estado del contrato y autorizará de ser el caso, la liberación de la refegarantía en un porcentaje máximo del $80 \%$ de lo alli depositado en ese periodo. Lo anterior previa presentación y gestión por parte del CONTRATISTA de un certificado de la oficina de gestión social del área de influencia de la ejecución de las ordenes de trabajo del periodo a liberar, de fijación y desfijacion de la notificación

\section{CLAUSULA SEXTA.-OBLIGACIONES DEL CONTRATISTA}

EI CONTRATISTA se obliga a ejecutar el objeto del Contrato, por to cual tendrá las siguientes obligaciones, además de las que se desprendan de otras cláusulas consignadas en este documento:

1. Respetar, con arreglo a la ley, los derechos de propiedad industrial (patentes, marcas, etc.) y los derechos patrimoniales y morales de autor.

2. Cumplir las obligaciones emanadas del Contrato de manera tal que no infrinja o viole, por obtención ilegal, derechos de patentes, secretos industriales, derechos de autor o cualquier otro derecho de propiedad de terceros.

3. Contratar, asumiendo los costos, todo el personal idóneo y calificado de directivos, profesionales, técnicos y de soporte administrativo que sean necesarios para el idóneo desarrollo del Contrato, de 


\section{ecoretrol}

conformidad con lo previsto en las CEC o en sus anexos, y/o en el cronograma de trabajo aprobado por ECOPETROL S.A.

Sobre el particular, el CONTRATISTA deberá verificar que ninguna de las personas por él vinculadas para la ejecución del Contrato, está incursa en la prohibición que consagra el articulo 47 de los Estatutos de ECOPETROL. S.A., o en la que obra en el numeral 22 del artículo 35 de la Ley 734 de 2002.

En caso de que se exija la presentación de un Equipo Minimo de Trabajo, el CONTRATISTA deberá indicar quienes serán los integrantes del mismo a más tardar en la fecha de suscripción del Acta de Inicio del Contrato, entregando debidamente diligenciado el formato que se exija, o adjuntando hoja de vida. En todo caso se deberá aportar la documentación que acredite sus estudios y experiencia.

Todo el personal integrante del Equipo Minimo de Trabajo exigido debe cumplir con todos y cada uno de los requisitos y exigencias establecidas para cada uno de los cargos a desempeñar. De lo contrario, ECOPETROL S.A. podrá proceder a imponer las sanciones previstas en el Contrato.

Excepto en el evento en que en las CEC se establezca algo diferente, una misma persona no podrá desempeñar más de uno de los cargos o perfiles. Si se ofrece a una misma persona para desempeñar más de un cargo del Equipo Minimo de Trabajo, ECOPETROL S.A. sólo la tendrá en cuenta para un cargo, y considerará vacante el (los) otro(s), pudiendo proceder a imponer las sanciones previstas en el Contrato.

4. El CONTRATISTA es libre de establecer el número de personas a utilizar en la ejecución del Contrato, de acuerdo con el enfoque de organización que dé al mismo.

No obstante lo anterior, durante la ejecución del Contrato el CONTRAȚISTA deberá contar como mínimo con el Equipo de Trabajo que se describe a continuación:

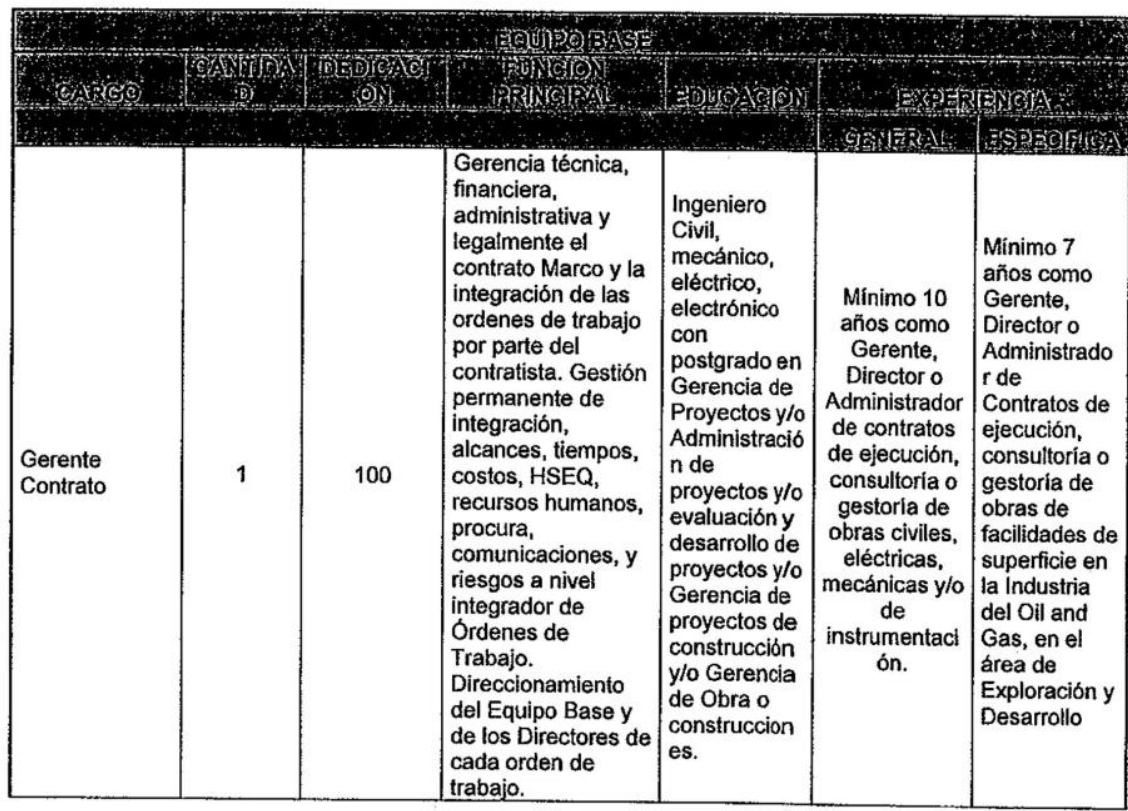


CONTRATO N MA-0018531

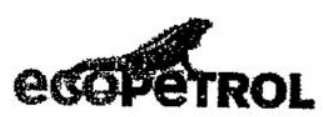

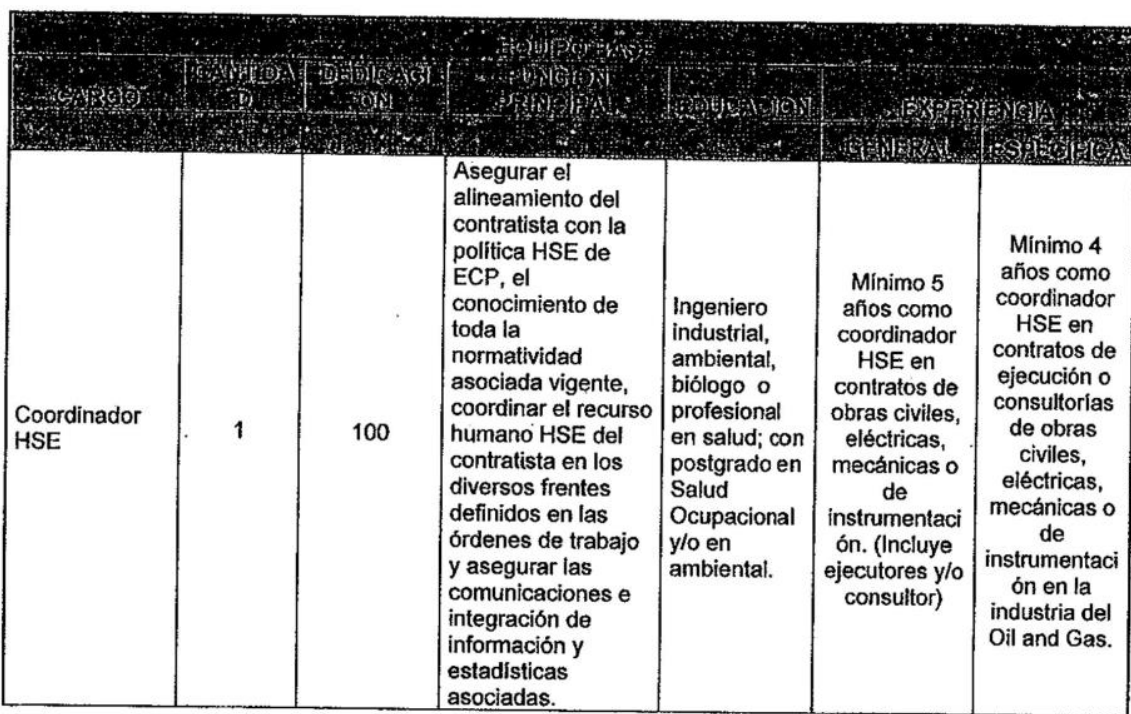

$Y$ durante la ejecución de las Ordenes de Trabajo (Dependiendo de la especialidad de la misma y de lo indicado en el texto misma de la OT) el CONTRATISTA deberá contar como mínimo con el Equipo de Trabajo que se describe a continuación:

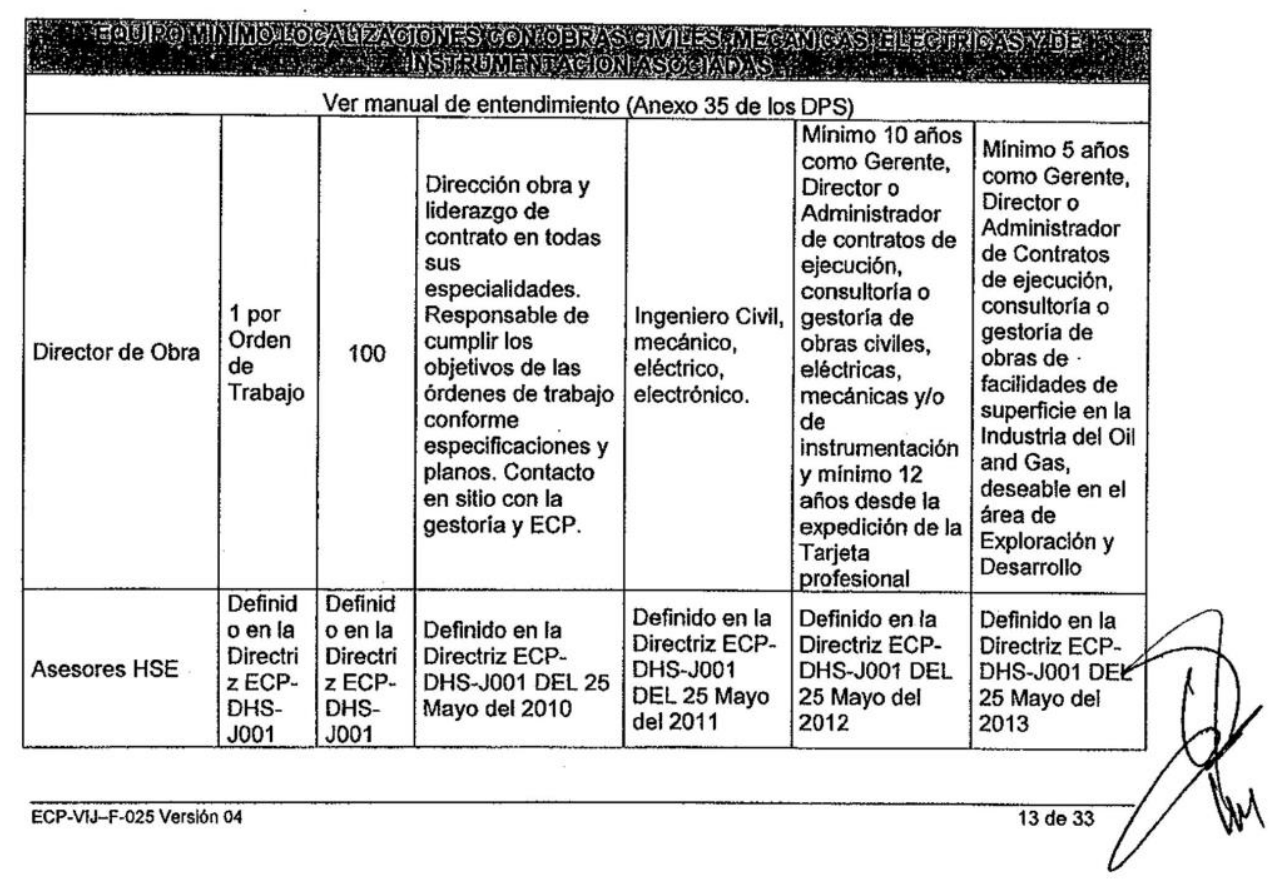


CONTRATO N MA-0018531

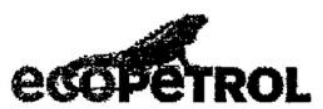

\begin{tabular}{|c|c|c|c|c|c|c|}
\hline & $\begin{array}{l}\text { DEL 25 } \\
\text { Mayo } \\
\text { del } \\
2008 .\end{array}$ & $\begin{array}{l}\text { DEL 25 } \\
\text { Mayo } \\
\text { del } \\
2009\end{array}$ & & & & \\
\hline Residente Civil & $\begin{array}{l}1 \text { por } \\
\text { Orden } \\
\text { de } \\
\text { Trabajo } \\
\text { o frente }\end{array}$ & 100 & $\begin{array}{l}\text { Responsable } \\
\text { obras civiles } \\
\text { conforme } \\
\text { especificaciones y } \\
\text { planos }\end{array}$ & Ingeniero Civil & $\begin{array}{l}\text { Mínimo } 10 \text { años } \\
\text { desde la } \\
\text { expedición de la } \\
\text { matrícula } \\
\text { profesional, } \\
\text { mínimo } 7 \text { años } \\
\text { como Director o } \\
\text { residente de } \\
\text { obras civiles }\end{array}$ & $\begin{array}{l}\text { Minimo } 5 \text { años } \\
\text { como Director o } \\
\text { residente de } \\
\text { obras civiles en } \\
\text { la Industria del } \\
\text { Oil and gas } \\
\text { especificament } \\
\text { e en } \\
\text { Localizaciones } \\
\text { u obras viales. } \\
\end{array}$ \\
\hline $\begin{array}{l}\text { Residente } \\
\text { Eléctrico }\end{array}$ & $\begin{array}{l}1 \text { por } \\
\text { Orden } \\
\text { de } \\
\text { Trabajo } \\
\text { o frente }\end{array}$ & 100 & $\begin{array}{l}\text { Responsable } \\
\text { obras eléctricas } \\
\text { conforme } \\
\text { especificaciones y } \\
\text { planos }\end{array}$ & $\begin{array}{l}\text { Ingeniero } \\
\text { Electricista }\end{array}$ & $\begin{array}{l}\text { Mínimo } 10 \text { años } \\
\text { desde la } \\
\text { expedición de la } \\
\text { matrícula } \\
\text { profesional, } \\
\text { mínimo } 7 \text { años } \\
\text { como Director o } \\
\text { residente de } \\
\text { obras Eléctricas }\end{array}$ & $\begin{array}{l}\text { Minimo } 5 \text { años } \\
\text { como Director o } \\
\text { residente de } \\
\text { obras eléctricas } \\
\text { en la Industria } \\
\text { del Oil and gas } \\
\text { especificament } \\
\text { e en Líneas } \\
\text { eléctricas } \\
\text { asociadas a } \\
\text { localizaciones y } \\
\text { subestaciones. }\end{array}$ \\
\hline $\begin{array}{l}\text { Residente } \\
\text { Mecánico }\end{array}$ & $\begin{array}{l}1 \text { por } \\
\text { Orden } \\
\text { de } \\
\text { Trabajo } \\
\text { o frente } \\
\text { si } \\
\text { incluye } \\
\text { más de } \\
\text { un } \\
\text { cluster }\end{array}$ & 100 & $\begin{array}{l}\text { Responsable } \\
\text { montajes } \\
\text { electromecánicos } \\
\text { conforme } \\
\text { especificaciones y } \\
\text { planos }\end{array}$ & $\begin{array}{l}\text { Ingeniero } \\
\text { Mecánico o } \\
\text { Electromecáni } \\
\text { co }\end{array}$ & $\begin{array}{l}\text { Mínimo } 10 \text { años } \\
\text { desde la } \\
\text { expedición de la } \\
\text { matrícula } \\
\text { profesional, } \\
\text { mínimo } 7 \text { años } \\
\text { como Director o } \\
\text { residente de } \\
\text { montajes } \\
\text { electromecánic } \\
\text { os o mecánicos }\end{array}$ & $\begin{array}{l}\text { Minimo } 5 \text { años } \\
\text { como Director o } \\
\text { residente de } \\
\text { montajes } \\
\text { mecánicos o } \\
\text { electromecánic } \\
\text { os en la } \\
\text { Industria del Oil } \\
\text { and gas } \\
\text { especificament } \\
\text { e en Lineas de } \\
\text { flujo, troncales, } \\
\text { montajes } \\
\text { mecánicos } \\
\text { asociados a } \\
\text { localizaciones }\end{array}$ \\
\hline $\begin{array}{l}\text { Residente } \\
\text { Instrumentación }\end{array}$ & $\begin{array}{l}1 \text { por } \\
\text { Orden } \\
\text { de } \\
\text { Trabajo } \\
\text { o frente } \\
\text { si } \\
\text { incluye } \\
\text { más de } \\
\text { un } \\
\text { cluster }\end{array}$ & 100 & $\begin{array}{l}\text { Responsable } \\
\text { actividades } \\
\text { Instrumentación y } \\
\text { control conforme } \\
\text { especificaciones y } \\
\text { planos }\end{array}$ & $\begin{array}{l}\text { Ingeniero } \\
\text { Electrónico o } \\
\text { Instrumentació } \\
\text { n o Carreras } \\
\text { afines }\end{array}$ & $\begin{array}{l}\text { Minimo } 10 \text { años } \\
\text { desde la } \\
\text { expedición de la } \\
\text { matrícula } \\
\text { profesional, } \\
\text { minimo } 7 \text { años } \\
\text { como Director o } \\
\text { residente de } \\
\text { obras de } \\
\text { instrumentación } \\
\text { o control } \\
\text { avanzado o } \\
\end{array}$ & $\begin{array}{l}\text { Mínimo } 5 \text { años } \\
\text { como Director o } \\
\text { residente en la } \\
\text { Industria del Oil } \\
\text { and gas } \\
\text { especificament } \\
\text { e en } \\
\text { instrumentación } \\
\text { control } \\
\text { avanzado o } \\
\text { automatización }\end{array}$ \\
\hline
\end{tabular}


CONTRATO N MA-0018531

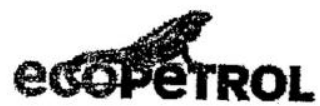

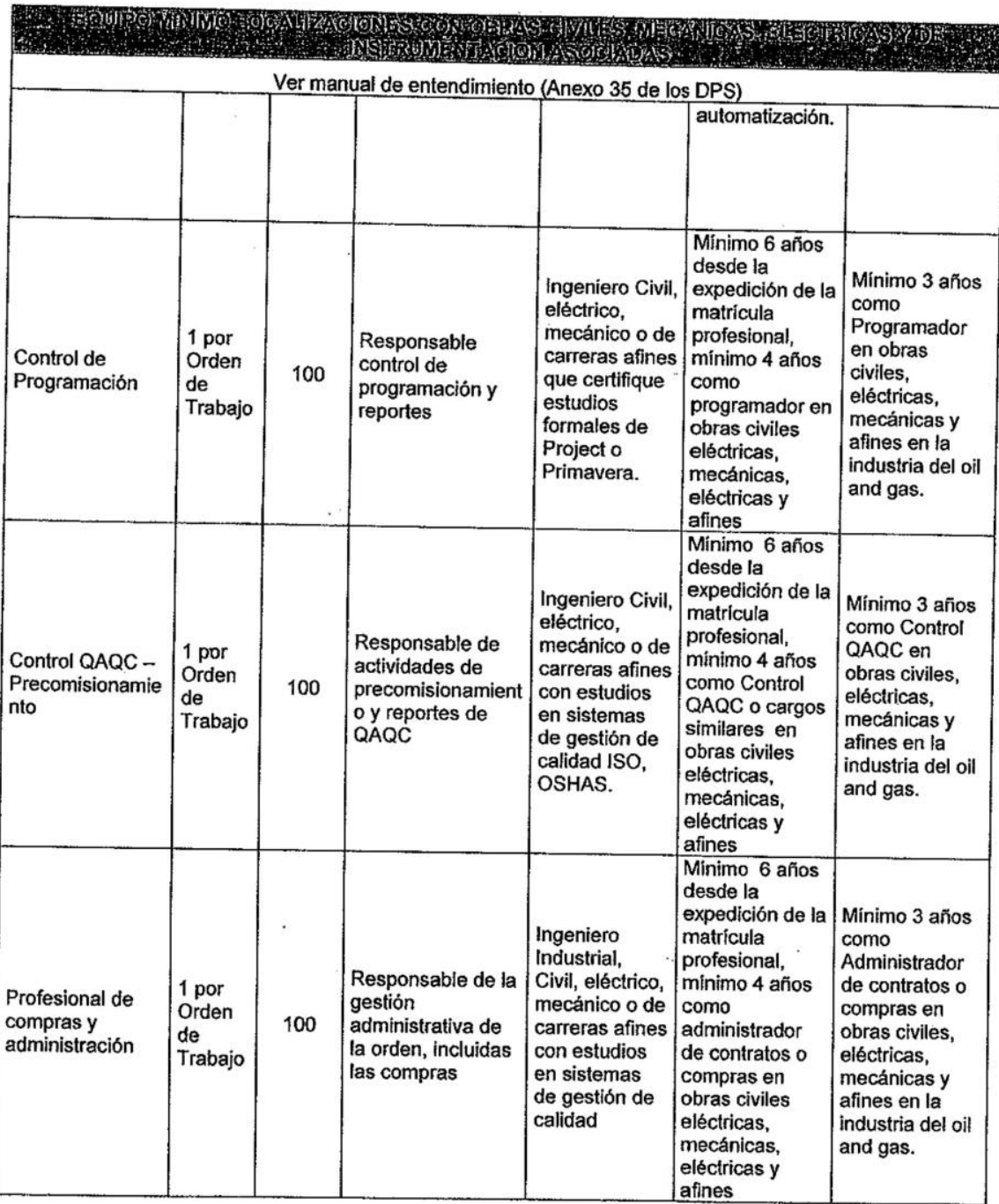


CONTRATO $N^{\circ}$ MA-0018531

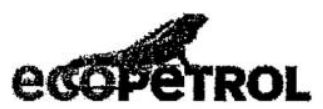

\begin{tabular}{|c|c|c|c|c|c|c|}
\hline ( & 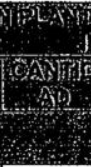 & 9 & 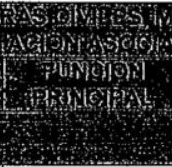 & 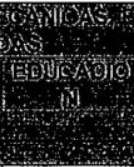 & 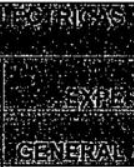 & F P \\
\hline Director de Obra & $\begin{array}{l}1 \text { por } \\
\text { Orden } \\
\text { de } \\
\text { Trabajo }\end{array}$ & 100 & $\begin{array}{l}\text { Dirección obra } \\
\text { y liderazgo de } \\
\text { contrato en } \\
\text { todas sus } \\
\text { especialidades. } \\
\text { Responsable } \\
\text { de cumplir los } \\
\text { objetivos de las } \\
\text { órdenes de } \\
\text { trabajo } \\
\text { conforme } \\
\text { especificacione } \\
\text { s y planos. } \\
\text { Contacto en } \\
\text { sitio con la } \\
\text { gestoria y ECP. }\end{array}$ & $\begin{array}{l}\text { Ingeniero } \\
\text { Civil, } \\
\text { mecánico, } \\
\text { eléctrico, } \\
\text { electrónico } \\
\text { o carreras } \\
\text { afines. }\end{array}$ & \begin{tabular}{|l} 
Minimo 12 \\
años como \\
Gerente, \\
Director o \\
Administrad \\
or de \\
contratos \\
de \\
ejecución, \\
consultoria \\
o gestoría \\
de obras \\
civiles, \\
eléctricas, \\
mecánicas \\
ylo de \\
instrumenta \\
ción y \\
minimo 15 \\
años desde \\
la \\
expedición \\
de la \\
Tarjeta \\
profesional
\end{tabular} & $\begin{array}{l}\text { Minimo } 10 \\
\text { años como } \\
\text { Gerente, } \\
\text { Directoro } \\
\text { Administrad } \\
\text { or de } \\
\text { Contratos } \\
\text { de } \\
\text { ejecución, } \\
\text { consultoria } \\
\text { o Gestoria } \\
\text { de Plantas } \\
\text { y/o } \\
\text { sistemas } \\
\text { industriales } \\
\text { en la } \\
\text { Industria del } \\
\text { Oil and } \\
\text { Gas, } \\
\text { deseable en } \\
\text { el área de } \\
\text { Exploración } \\
\text { y Desarrollo }\end{array}$ \\
\hline Coordinador HSE & 1 & 100 & $\begin{array}{l}\text { Asegurar el } \\
\text { alineamiento } \\
\text { del contratista } \\
\text { con la politica } \\
\text { HSE de ECP, el } \\
\text { conocimiento } \\
\text { de toda la } \\
\text { normatividad } \\
\text { asociada } \\
\text { vigente, } \\
\text { coordinar el } \\
\text { recurso } \\
\text { humano HSE } \\
\text { del contratista } \\
\text { en los diversos } \\
\text { frentes } \\
\text { definidos en las } \\
\text { órdenes de } \\
\text { trabajo y } \\
\text { asegurar las } \\
\text { comunicacione } \\
\text { s e integración } \\
\text { de información } \\
\text { y estadisticas } \\
\text { asociadas. } \\
\end{array}$ & $\begin{array}{l}\text { Ingeniero } \\
\text { industrial, } \\
\text { ambiental, } \\
\text { biólogo o } \\
\text { carreras } \\
\text { afines con } \\
\text { especializac } \\
\text { ión en } \\
\text { Salud } \\
\text { Ocupaciona } \\
\text { lo afines }\end{array}$ & $\begin{array}{c}\text { Mínimo } 5 \\
\text { años como } \\
\text { coordinador } \\
\text { o cargos } \\
\text { similares } \\
\text { HSE en } \\
\text { contratos } \\
\text { de } \\
\text { ejecución o } \\
\text { consultorias } \\
\text { de obras } \\
\text { civiles, } \\
\text { eléctricas, } \\
\text { mecánicas } \\
\text { o de } \\
\text { instrumenta } \\
\text { ción. }\end{array}$ & $\begin{array}{c}\text { Minimo } 4 \\
\text { años como } \\
\text { coordinador } \\
\text { HSE en } \\
\text { contratos } \\
\text { de } \\
\text { ejecución o } \\
\text { consultorias } \\
\text { de Plantas } \\
\text { o Sistemas } \\
\text { Industriales } \\
\text { en la } \\
\text { industria del } \\
\text { Oil and } \\
\text { Gas. }\end{array}$ \\
\hline
\end{tabular}


CONTRATO $N^{\circ}$ MA-0018531

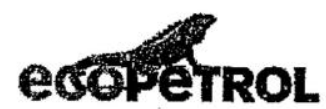

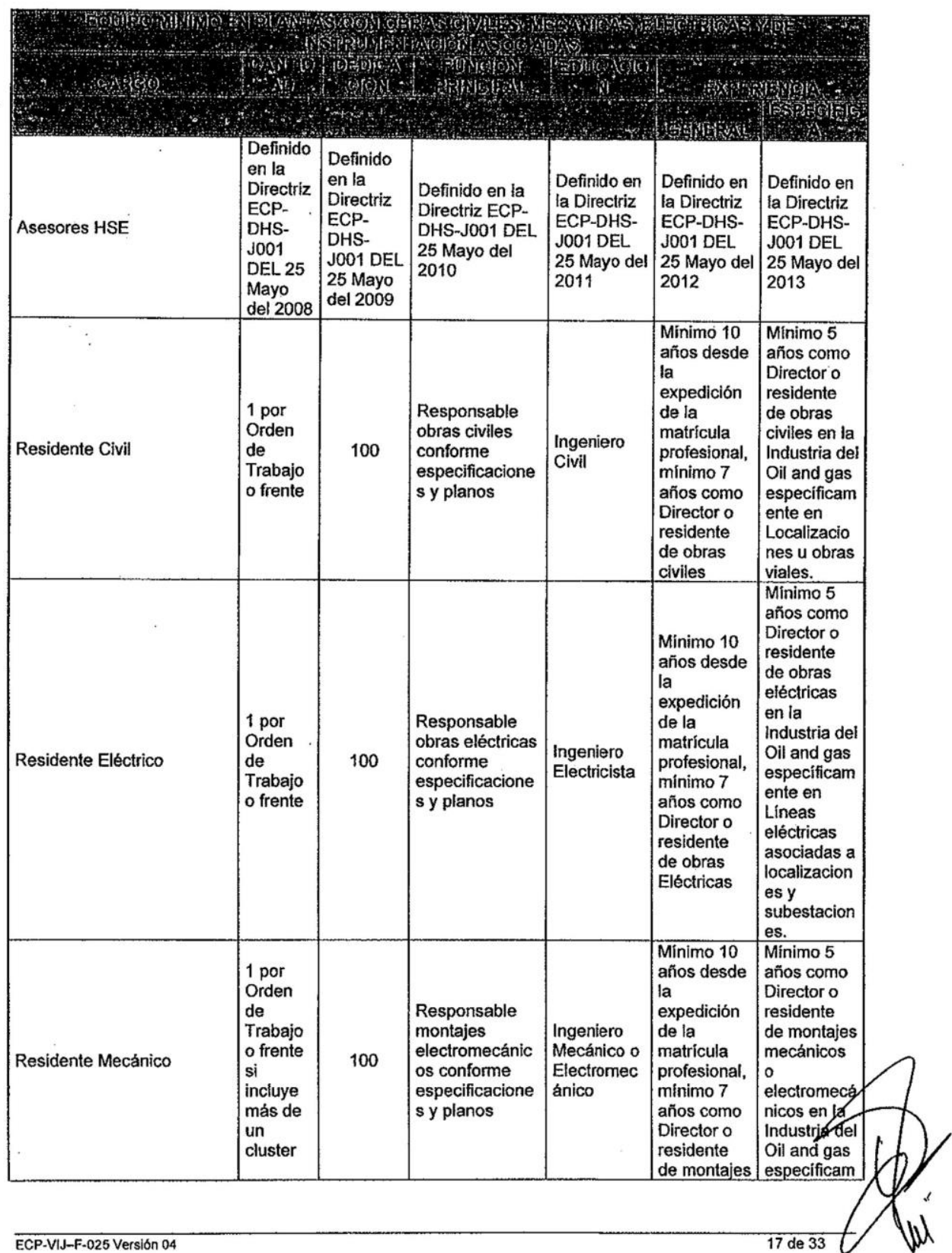


CONTRATO N'MA-0018531

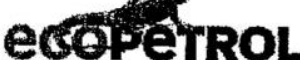

\begin{tabular}{|c|c|c|c|c|c|c|}
\hline & & . & & & \begin{tabular}{|l|} 
electromecá \\
nicos o \\
mecánicos
\end{tabular} & $\begin{array}{l}\text { ente en } \\
\text { Lineas de } \\
\text { flujo, } \\
\text { troncales, } \\
\text { montajes } \\
\text { mecánicos } \\
\text { asociados a } \\
\text { localizacion } \\
\text { es }\end{array}$ \\
\hline Residente Instrumentación & $\begin{array}{l}1 \text { por } \\
\text { Orden } \\
\text { de } \\
\text { Trabajo } \\
\text { o frente } \\
\text { si } \\
\text { incluye } \\
\text { más de } \\
\text { un } \\
\text { cluster }\end{array}$ & 100 & \begin{tabular}{|l|} 
Responsable \\
actividades \\
Instrumentación \\
y control \\
conforme \\
especificacione \\
s y planos
\end{tabular} & $\begin{array}{l}\text { Ingeniero } \\
\text { Electrónico } \\
\text { o } \\
\text { Instrumenta } \\
\text { ción o } \\
\text { Carreras } \\
\text { afines }\end{array}$ & \begin{tabular}{|l|} 
Mínimo 10 \\
años desde \\
la \\
expedición \\
de la \\
matricula \\
profesional, \\
mínimo 7 \\
años como \\
Director o \\
residente \\
de de \\
instrumenta \\
ción, control \\
avanzado o \\
automatizac \\
ión \\
\end{tabular} & \begin{tabular}{|l|} 
Mínimo 5 \\
años como \\
Director o \\
residente \\
en la \\
Industria del \\
Oil and gas \\
especificam \\
ente en \\
instrumenta \\
ción, contro! \\
avanzado o \\
automatizac \\
ión.
\end{tabular} \\
\hline Control de Programación & $\begin{array}{l}1 \text { por } \\
\text { Orden } \\
\text { de } \\
\text { Trabajo }\end{array}$ & 100 & \begin{tabular}{|l|} 
Responsable \\
control de \\
programación y \\
reportes
\end{tabular} & $\begin{array}{l}\text { Ingeniero } \\
\text { Civil, } \\
\text { eléctrico, } \\
\text { mecánico o } \\
\text { de carreras } \\
\text { afines que } \\
\text { certifique } \\
\text { estudios } \\
\text { formales de } \\
\text { Project o } \\
\text { Primavera. }\end{array}$ & \begin{tabular}{|l|} 
Mínimo 10 \\
años desde \\
la \\
expedición \\
de la \\
matrícula \\
profesional, \\
mínimo 6 \\
años como \\
programado \\
r en obras \\
civiles \\
eléctricas, \\
mecánicas, \\
eléctricas y \\
afines \\
\end{tabular} & $\begin{array}{l}\text { Mínimo } 4 \\
\text { años como } \\
\text { Programad } \\
\text { or en obras } \\
\text { Plantas y } \\
\text { Sistemas } \\
\text { industriales } \\
\text { en la } \\
\text { industria del } \\
\text { oil and gas. }\end{array}$ \\
\hline $\begin{array}{l}\text { Control QAQC - } \\
\text { Precomisionamiento }\end{array}$ & $\begin{array}{l}1 \text { por } \\
\text { Orden } \\
\text { de } \\
\text { Trabajo }\end{array}$ & 100 & $\begin{array}{l}\text { Responsable } \\
\text { de actividades } \\
\text { de } \\
\text { precomisionami } \\
\text { ento y reportes } \\
\text { de QAQC }\end{array}$ & \begin{tabular}{|l|} 
Ingeniero \\
Civil, \\
eléctrico, \\
mecánico o \\
de carreras \\
afines con \\
estudios en \\
sistemas de \\
gestión de \\
calidad ISO. \\
\end{tabular} & $\begin{array}{l}\text { Mínimo } 10 \\
\text { años desde } \\
\text { la } \\
\text { expedición } \\
\text { de la } \\
\text { matrícula } \\
\text { profesional, } \\
\text { minimo } 4 \\
\text { años como } \\
\text { Control } \\
\end{array}$ & $\begin{array}{l}\text { Minimo } 4 \\
\text { años como } \\
\text { Control } \\
\text { QAQC en } \\
\text { obras de } \\
\text { Plantas o } \\
\text { Sistemas } \\
\text { Industriales } \\
\text { en la } \\
\text { industria del }\end{array}$ \\
\hline
\end{tabular}


CONTRATO N MA-0018531

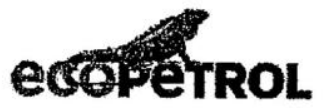

\begin{tabular}{|c|c|c|c|c|c|c|}
\hline \\
\hline \multicolumn{7}{|c|}{ 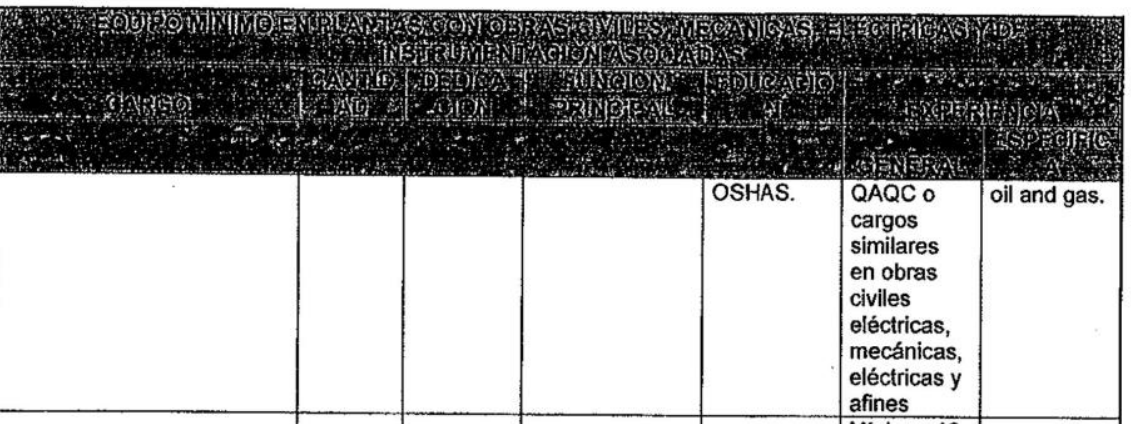 } \\
\hline $\begin{array}{l}\text { Profesional de compras y } \\
\text { administración }\end{array}$ & $\begin{array}{l}1 \text { por } \\
\text { Orden } \\
\text { de } \\
\text { Trabajo }\end{array}$ & 100 & $\begin{array}{l}\text { Responsable } \\
\text { de la gestión } \\
\text { administrativa } \\
\text { de la orden, } \\
\text { incluidas las } \\
\text { compras }\end{array}$ & $\begin{array}{l}\text { Ingeniero } \\
\text { industrial, } \\
\text { Civil, } \\
\text { eléctrico, } \\
\text { mecánico o } \\
\text { de carreras } \\
\text { afines con } \\
\text { estudios en } \\
\text { sistemas de } \\
\text { gestión de } \\
\text { calidad }\end{array}$ & $\begin{array}{l}\text { Mínimo } 10 \\
\text { años desde } \\
\text { la } \\
\text { expedición } \\
\text { de la } \\
\text { matricula } \\
\text { profesional, } \\
\text { mínimo } 6 \\
\text { años como } \\
\text { administrad } \\
\text { or de } \\
\text { contratos o } \\
\text { compras en } \\
\text { obras } \\
\text { civiles } \\
\text { eléctricas, } \\
\text { mecánicas, } \\
\text { eléctricas y } \\
\text { afines }\end{array}$ & $\begin{array}{l}\text { Minimo } 4 \\
\text { años como } \\
\text { Administrad } \\
\text { or de } \\
\text { contratos o } \\
\text { compras en } \\
\text { obras de } \\
\text { Plantas o } \\
\text { Sistemas } \\
\text { Industriales } \\
\text { en la } \\
\text { industria del } \\
\text { oil and gas. }\end{array}$ \\
\hline $\begin{array}{l}\text { Supervisores civiles, } \\
\text { eléctricos, mecánicos o e } \\
\text { instrumentación }\end{array}$ & $\begin{array}{l}1 \text { por } \\
\text { especiali } \\
\text { dad por } \\
\text { Orden } \\
\text { de } \\
\text { Trabajo }\end{array}$ & 100 & $\begin{array}{l}\text { Responsable } \\
\text { de la ejecución } \\
\text { y liderazgo de } \\
\text { cuadrillas } \\
\text { especializadas }\end{array}$ & $\begin{array}{l}\text { Tecnólogos } \\
\text { en obras } \\
\text { civiles, } \\
\text { eléctricas, } \\
\text { electromecá } \\
\text { nicas o } \\
\text { mecánicos } \\
\text { y de } \\
\text { instrumenta } \\
\text { ción }\end{array}$ & $\begin{array}{l}\text { Mínimo } 10 \\
\text { años de } \\
\text { experiencia } \\
\text { en } \\
\text { supervisión } \\
\text { de } \\
\text { actividades } \\
\text { por cada } \\
\text { especialida } \\
\text { d }\end{array}$ & $\begin{array}{l}\text { Mínimo } 5 \\
\text { años de } \\
\text { experiencia } \\
\text { en } \\
\text { supervisión } \\
\text { de } \\
\text { actividades } \\
\text { por cada } \\
\text { especialida } \\
\text { d en la } \\
\text { industrial } \\
\text { del Oil and } \\
\text { Gas. } \\
\end{array}$ \\
\hline
\end{tabular}

5. En caso de que la orden de trabajo tenga relación laboral sometida a ley colombiana con todos o algunos de los integrantes de su equipo de trabajo, el CONTRATISTA se obliga a pagarles el salario establecido por ECOPETROL S.A. e informado en los DPS, o, en defecto de dicha información, el salario que corresponda de acuerdo con la normativa interna de ECOPETROL S.A. en materia de salarios a cargo de sus contratistas, la cual podrá ser consultada en la página Web www.ecopetrol.com.co, en la rưo Compras y Contratación/Normativa Extensiva a Contratistas. En cuanto a las prestaciones sociales se deberán reconocer como minimo las consagradas en el Código Sustantivo del Trabajo y las normas que lo adicionan o modifican. 
Si durante la ejecución del Contrato ECOPETROL S.A. introduce modificaciones al salario informado en los DPS o a la normativa indicada, que impliquen incremento en el salario, no considerado en la propuesta que dio lugar al Contrato ni en éste el CONTRATISTA se obliga a cumplir con lo dispuesto en dichas modificaciones, y, para el efecto, hará los ajustes salariales, prestacionales y de protección social a sus trabajadores con derecho a los mismos. Este ajuste será reconocido por ECOPETROL en los términos descritos en la clausula cuarta FORMA DE PAGO del presente CONTRATO, en caso que la formula alli descrita no sea aplicable, ECOPETROL S.A. y el CONTRATISTA suscribirán el respectivo contrato adicional a efecto de cubrir la diferencia entre el salario con el que el CONTRATISTA estructuró su oferta y el ajuste realizado, asi como la diferencia sobre las prestaciones sociales, aportes al Sistema de Protección Social, trabajo suplementario y en dias de descanso (dominicales, festivos y horas extra). No habrá lugar al pago de Imprevistos ni de Utilidades a favor del CONTRATISTA; únicamente se pagará una Administración del $5 \%$.

Será por cuenta del CONTRATISTA el pago de salarios, prestaciones sociales e indemnizaciones de todo el personal que ocupe en la ejecución del Contrato. Por consiguiente, serán de cargo del CONTRATISTA las indemnizaciones que se causaren por concepto de terminación unilateral de contratos de trabajo.

Se precisa que es responsabilidad única y absoluta del contratista efectuar de manera correcta y oportuna los pagos de carácter laboral (salarios, prestaciones sociales, aportes al sistema de protección social, aportes al FIC) originados de la ejecución del presente contrato; ECOPETROL S.A se reserva la facultad de efectuar controles posteriores para evitar falencias o errores de cálculos o pagos; hiciera, el CONTRATISTA deberá realizar las modificaciones que se le indiquen. Por lo tanto es su obligación escoger personal idóneo en el desarrollo de estas actividades.

Si la orden de trabajo. tuviere régimen salarial y prestacional convencional, por efecto de la aplicación del Decreto 284 de 1957 o actas de acuerdo ECOPETROL S.A. - USO del 12 de diciembre de 2008 y 22 de agosto de 2009 y Disposición Salarial del 16 de septiembre de 2010 construcción y mantenimiento de sistemas contra incendio, el CONTRATISTA se obliga a pagar a todo el personal que vincule de manera exclusiva a la ejecución de aquel, como minimo, los salarios y prestaciones previstos en el Régimen Convencional de ECOPETROL S.A.

Los salarios y prestaciones del personal no escalafonado del CONTRATISTA, serán los acordados por las partes, en aplicación del principio de autonomía de la voluntad, pero en ningún caso serán inferiores a los establecidos en la Tabla de Niveles Salariales para Carrera Técnica y Administrativa de ECOPETROL S.A., la cual podrá ser consultada en la página Web www.ecopetrol.com.co, en la ruta Compras y Contratación/Normativa Extensiva a Contratistas.

6. Movilizar y mantener disponibles y en buenas condiciones, los materiales, equipos, herramientas y accesorios y todos los demás elementos necesarios para la ejecución de las obras, de acuerdo con lo ofrecido en la propuesta económica y lo exigido en los DPS. El Contratista obras, de acuerdo con lo integridad y seguridad del equipo dispuesto para la realización de las obras.

7. A suministrar, tanto en cantidad y calidad como en tiempo, toda la maquinaria de construcción, los equipos de transporte, las máquinas, herramientas, materiales, accesorios y todos los demás elementos necesarios para la construcción de las obras.

8. En los casos en que los materiales, equipos y herramientas fallen o no garanticen las obras, ECOPETROL podrá contratarlo(s) o arrendarlo(s) y cobrar al CONTRATISTA los gastos en que incurra más un $10 \%$ de administración, siempre y cuando el CONTRATISTA haya tenido la oportunidad de remediar la situación, ya sea por reemplazo o reparación, y no lo haya hecho en un lapso de 72 horas.

9. Manejar correctamente los materiales requeridos para la ejecución de las obras, realizando las labores de cargue, descargue y transporte de los mismos, manteniendo permanentemente un inventario de los materiales. 


\section{CONTRATO N MA-0018531}

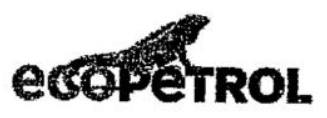

10. Suministrar y operar los generadores eléctricos necesarios para proveer sus necesidades eléctricas y los insumos tales como: combustibles, lubricantes, materiales, y provisiones requeridos para efectuar eficientemente las operaciones pactadas.

11. Proveer el transporte adecuado para cumplir con sus compromisos contractuales. Por lo tanto, será responsable por el transporte de los materiales desde su fuente hasta el sitio de ejecución de las obras, del transporte de trabajadores y del transporte de todos los equipos y provisiones requeridos para efectuar eficientemente las obras pactadas.

12. Mantener la seguridad y en consecuencia evitar accidentes y responder por los daños que se causen a personas o bienes, por imprevisión, negligencia o descuido, impericia o imprudencia, dentro o fuera del área donde se van a efectuar las obras, atribuibles al CONTRATISTA o a sus dependientes o subcontratistas. Por lo tanto es su obligación escoger personal o subcontratistas idóneos y vigilarlos en el desarrollo de sus actividades. Se aclara que la gestión de seguridad en idoneos y vigilarlos en el responsabilidad del CONTRATISTA. ECOPETROL de verificar que el CONTRATISTA cumpla con la salud, el medio ambiente y la calidad. Corresponde a este último escoger personal idóneo en el desarrollo de estas actividades y realizar las gestiones necesarias con el fin de desarrollar el concepto de autocuidado y cuidado del ambiente en sus trabajadores.

13. Limpiar y remover todos los escombros generados por el CONTRATISTA, del sitio de las obras hasta el lugar indicado como sitio de disposición, que cuente con las autorizaciones legales respectivas.

14. Mantener y entregar el sitio de trabajo en perfectas condiciones de aseo e higiene, durante la ejecución y hasta la entrega final de las actividades objeto de las órdenes de trabajo.

15. Realizar de inmediato las reparaciones o modificaciones que indique ECOPETROL, acorde a las especificaciones técnicas y lo pactado en el contrato.

16. Responder, sin perjuicios de la respectiva garantia, por la estabilidad de las obras contratadas.

17. Cumplir las disposiciones legales vigentes para el uso y protección de la infraestructura y las redes de los servicios públicos, cuando fuere necesario para la ejecución de las obras, solicitando previamente la respectiva autorización ante la Entidad competente.

18. Responder en un plazo de quince (15) dias calendario por los daños que se causen a bienes o instalaciones de ECOPETROL. S.A., infraestructura pública o privada, sea por culpa suya, de sus trabajadores o de sus subcontratistas.

19. Cumplir con las obligaciones consagradas en el instructivo de responsabilidad empresarial (ECP-DAB-P. 054) emitido por ECOPETROL S.A. Ver Anexo No. 12.

20. Iniciar la ejecución de las obras en un término máximo de tres (3) días calendario, contados a partir de la suscripción del acta de inicio de cada orden de trabajo.

21. Son obligaciones contractuales las adquiridas por el CONTRATISTA en la reunión de inicio o kick of meeting.

22. Entregar a ECOPETROL S.A., dentro de los cinco (5) dias siguientes a la fecha de notificación de cada Orden de Trabajo, un programa de trabajo por el método de la ruta critica (CPM); ECOPETROL S.A. dentro de los tres (3) dias hábiles siguientes lo revisará, objetará o aprobará; a su vez el CONTRATISTA deberá ajustar su programa en el caso que ECOPETROL. S.A. asi lo solicite, dentro de los dos (2) dias hábiles siguientes, con el fin de iniciar la obra en el término acordado en la respectiva orden de trabajo. Este programa será la base para la construcción de las obras. La entrega o aprobación del CPM no afectará el plazo fijado en el contrato para la iniciación y finalización de las obras.

23. Mantener en cada uno de los frentes de obra, en buen estado un ejemplar de las especificaciones, un gráfico donde se muestre el avance o retardo comparado con el programa de trabajo y una copia de 


\section{CONTRATO N MA-0018531}

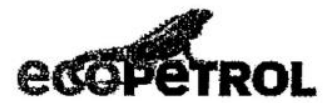

todos los documentos y planes del Proyecto en materia de Higiene, Seguridad Industrial y Salud Ocupacional.

24. Realizar las actividades de precomisionamiento a los equipos y sistemas incluidos en el alcance de los Trabajos.

25. Facilitar y acordar la participación del personal de ECOPETROL. S.A. en el "Precomisionamiento"

26. Realizar las pruebas requeridas conforme a las especificaciones técnicas del contrato para los equipos que hayan sido suministrados por el CONTRATISTA

27. Suministrar los equipos y cuadrillas que las actividades de comisionamiento requieran en coordinación con ECOPETROL S.A., las cuales serán pagadas acorde al ítem correspondiente.

28. Participar y atender las observaciones que resulten en el "Comisionamiento y Puesta en Servicio de las obras" y en las pruebas de garantias, según los términos establecidos.

29. Permitir en cualquier momento la inspección de los Trabajos por parte, de ECOPETROL S.A. y de sus representantes, así como de autoridades y funcionarios, en sus oficinas principales o en el lugar donde se estén ejecutando los Trabajos. Ninguna inspección, examen o prueba realizada por ECOPETROL S.A. o sus representantes eximirá al CONTRATISTA de ninguna de las obligaciones contenidas en este S.A. O sus representantes eximirá al CONTRATISTA de ninguna de las obligaciones contenidas en este
Contrato. Para tal efecto, ECOPETROL S.A. o sus representantes tendrán acceso a los detalles y documentos de trabajo, a especificaciones, dibujos, cálculos, órdenes de compra y subcontratos, al igual que a otros documentos preparados por el CONTRATISTA, por su Subcontratista, o por un Proveedor.

30. Cumplir con los requerimientos de Operación o Funcionamiento establecidos en las especificaciones técnicas, los cuales serán verificados mediante las pruebas de aceptación, que efectuará el céchicas, CONTRATISTA conforme a lo indicado en este Contrato. Una vez hechas la pruebas de aceptación, en e caso de que no se alcancen dichos requerimientos acorde a lo que indique ECOPETROL S.A., el CONTRATISTA presentará de manera inmediata, sus recomendaciones sobre las acciones correctivas que deben ser tomadas para el cumplimento de los mismos, debiendo el CONTRATISTA repetir las pruebas, una vez se hayan efectuado las modificaciones aprobadas por ECOPETROL S.A sin costo adicional de los equipos y/o materiales y mano de obra en que se incurra por incumplimiento de plazo posible para ECOPETROL S.A., según lo permita el esquema logistico operacional de la obra objeto del contrato y cumpliendo con los plazos establecidos en el PDT correspondiente.

31. Proporcionar, antes de que se acepten los Trabajos de acuerdo con la cláusula respectiva, las instrucciones de operación y mantenimiento dispuestas en manuales, catálogos mecánicos, además de los dibujos "As Built" de los Trabajos tal y como fueron terminados. Estos manuales y dibujos deberán estar presentados en la forma y con los detalles que permitan a ECOPETROL S.A. hacer funcionar, mantener, ajustar y reparar todas las partes de la Obra. Se anexa procedimiento de "ECP-GTD-P-001".

32. Coordinar con el personal que ECOPETROL S.A. designe, la operación de los sistemas incluidos en el alcance de los Trabajos.

33. Designar a quien actuará como su representante o interlocutor frente a ECOPETROL S.A. en el desarrollo del Contrato.

34. Abstenerse de sustituir a los miembro(s) del Equipo de Trabajo, sin previa autorización expresa y escrita otorgada por el Gestor de la Orden de trabajo, incluido(s) en la propuesta presentada por CONTRATISTA, cuando la presencia de dicho personal fuere requerida de acuerdo con lo exigido en CEC, en este Contrato, en sus anexos, en la propuesta, o en el cronograma de trabajo aprobado por ECOPETROL S.A.

35. En caso que el personal del CONTRATISTA (o de subcontratistas suyos, si los DPS le permiten subcontratar o ECOPETROL S.A. lo autoriza de manera expresa, por escrito) trabaje en instalaciones de 


\section{CONTRATO N'MA-0018531}

\section{ecopertroL}

ECOPETROL S.A., el CONTRATISTA se obliga a mantener actualizada la información de aquel en relación con los siguientes aspectos:

Nombre,

Documento de identificación,

Domicilio,

Constancia de afiliación a los sistemas de salud, riesgos profesionales y pensiones,

Cargo que desempeña,

Salario, $y$

Los demás documentos que requiera ECOPETROL. S.A. para poder hacer revisiones del cumplimiento de obligaciones laborales a cargo del CONTRATISTA.

36. Impedir que uno o varios de los miembros de su personal (o el de sus subcontratistas, si los DPS le permiten subcontratar o ECOPETROL. S.A. lo autoriza de manera expresa, por escrito) que trabajen o ingresen a las instalaciones de ECOPETROL. S.A. esté bajo la influencia de licor, drogas o sustancias ingresen a las incinos.
alucinogenas.

37. Acatar la normatividad colombiana en la contratación de nacionales y extranjeros, al igual que el Régimen de Extranjería.

38. Vincular a la totalidad del personal, para la ejecución del Contrato, mediante contrato laboral y cumplir con sus obligaciones para con los sistemas de salud, riesgos profesionales, pensiones y aportes a las Cajas de Compensación Familiar, Instituto Colombiano de Bienestar Familiar y Servicio Nacional de Aprendizaje.

Tratándose de trabajadores extranjeros, éstos deben ser afiliados a los regimenes de salud y de riesgos profesionales de Colombia. En lo que hace al régimen de pensiones, si el extranjero se encuentra cubierto por algún sistema pensional de su país de origen o de cualquier otro diferente de Colombia, tal condición debe ser acreditada por el CONTRATISTA, y en ese evento la afiliación al régimen de pensiones colombiano será voluntaria. En el caso en que el extranjero no se encuentre afiliado a ningún régimen o sistema pensional de su pais de origen o de cualquier otro diferente de Colombia, el CONTRATISTA deberá afiliarlo obligatoriamente.

El Gestor de la orden de trabajo verificará el cumplimiento de estas obligaciones en la fecha de suscripción del acta de recibo parcial de los trabajos o servicios, teniendo en cuenta que las mismas se hayan causado, es decir, que de acuerdo con las normas legales que las regulan, sean exigibles al empleador.

39. Cumplir con el numeral 4.5.3 del Anexo No. 12 PROCEDIMIENTO RESPONSABILIDAD SOCIAL EMPRESARIAL de los DPS.

40. Cumplir con los compromisos comerciales que, para la ejecución del Contrato, adquiera con proveedores de bienes y servicios y/o subcontratistas (si los DPS le permiten subcontratar o ECOPETROL S.A. 10 autoriza de manera expresa, por escrito).

41. En desarrollo de su autonomla administrativa y conforme a las previsiones contenidas en la Política de Responsabilidad Social Empresarial de ECOPETROL S.A., atender y manejar las relaciones que con ocasión del Contrato establezca con sus trabajadores y grupos de interés, y en concordancia con ello, asistir a reuniones y responder las solicitudes, quejas, reclamos y demás eventos que se llegaren a presentar y que puedan afectar la ejecución de aquel, sin la intervención de ECOPETROL S.A., a menos que esta Sociedad considere conveniente su participación.

42. Entregar al Gestor de la orden de trabajo, en la fecha de suscripción del Acta de Inicio de la misma, identificación de las tareas críticas y los respectivos procedimientos e instructivos de tratajo cada una de ellas.

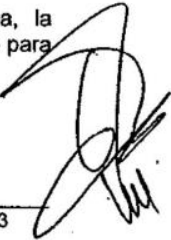




\section{CONTRATO $N^{\circ}$ MA-001853}

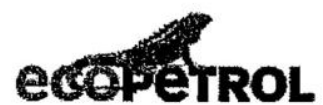

Se deberá cumplir con esta obligación únicamente en el evento en que personas del equipo de CONTRATISTA vayan a realizar trabajos en: Alturas mayores o iguales a un (1) metro, en espacios confinados (tanques de almacenamiento, silos, ductos de ventilación, túneles, tuberias, $u$ otros), con llama abierta o chispa (corte y soldadura con oxiacetileno, soldadura eléctrica, esmerilado, pulido, lijado, trabajo con chorro de abrasivos, rotura de concreto en seco, operación de equipos elécíricos no a prueba de explosión, u otros), o trabajos mecánicos y/o eléctricos.

43. Cuando con ocasión del objeto o alcance del Contrato se deban realizar actividades tales como construcción, interventoría o Gestión, recepción, operación, mantenimiento o inspección, que conlleven intervención de una instalación eléctrica, aquellas deberán ser ejecutadas en su totalidad por profesionales (ingenieros electricistas, ingenieros electromecánicos, ingenieros de distribución y redes eléctricas, o ingenieros electrónicos - lo ultimo únicamente en los temas de electrónica de potencia, control o compatibilidad electromagnética-), o por tecnólogos en electricidad, tecnólogos en electromecánica o técnicos electricistas, según sea requerido.

El CONTRATISTA, por lo menos cuatro (4) dias hábiles antes de iniciar actividades que impliquen intervención de una instalación eléctrica, deberá entregar al Gestor de la orden de trabajo un escrito en el que consigne los nombres de las personas que las realizarán, adjuntando en relación con cada una copia de su tarjeta profesional (para el caso de ingenieros) o del documento que acredite la especialidad correspondiente y la habilitación para el ejercicio de la misma (en el caso de tecnólogos). Este plazo no aplicara en caso de urgencias; en este ultimo evento, el CONTRATISTA deberá entregar al Gestor de la orden de trabajo la documentación anterior dentro de los tres (3) días hábiles siguientes a la solución de la urgencia, indicando por qué se presentó la misma.

EI CONTRATISTA deberá entregar certificado de vigencia de la inscripción y de conducta expedido por el Consejo Profesional competente dentro de los tres (3) meses anteriores, en relación con las personas para las cuales el Gestor de la Orden de trabajo to solicite.

44. Acatar las instrucciones de ECOPETROL S.A., o las impartidas por las personas designadas por esta Sociedad para ello, siempre y cuando éstas se impartan en desarrollo de las funciones que les corresponden con ocasión de la ejecución del Contrato.

45. Guardar, conservar y poner a disposición de ECOPETROL S.A. cuando esta Empresa to requiera, todos los comprobantes, registros, libros, recibos de cotizaciones, órdenes de compra, facturas, correspondencia y cualquier documentación de soporte, relacionada con el Contrato, durante el plazo de mismo y dos (2) años más. Durante dicho plazo ECOPETROL S.A. queda expresamente facultada por el CONTRATISTA para revisar sus tibros de contabilidad, su correspondencia y demás registros, con el propósito de verificar la exactitud de la información relativa al Contrato.

46. Entregar al Gestor de la orden de trabajo o al Administrador la documentación que ellos soliciten para verificar el cumplimiento de las obligaciones del CONTRATISTA en materias técnica, laboral, u otras.

47. Presentar las facturas para el cobro de los trabajos, servicios y/o suministros realizados a satisfacción de ECOPETROL S.A., dentro del plazo previsto en este Contrato, y anexar a ellas o aportar dentro de los términos de que dispone ECOPETROL. S.A. para aceptarlas o rechazarlas, los documentos contractualmente previstos para que su pago sea exigible.

48. Asistir, a través de su representante legal o de la persona designada como interlocutor ante ECOPETROL S.A. para efectos de la ejecución del Contrato, a por lo menos uno de los Talleres para la Prevención del Delito a los que convoque ECOPETROL.S.A.

49. Abstenerse de utilizar cualquier operación cambiaria o de comercio exterior que realice, como instrumento para el ocultamiento, manejo, inversión o aprovechamiento, en cualquier forma, de dinero u otros bienes provenientes de actividades delictivas o para dar apariencia de legalidad a las transacciones y fondos vinculados con las mismas.

50. Informar a ECOPETROL S.A. (Teléfonos 018000917045 - 2343345 - 2344092) y denunciar ante la autoridad competente los delitos de cuya comisión tenga conocimiento (corrupción, extorsión, falsedad 


\section{CONTRATO N MA-0018531}

\section{ecoriêrrol}

documental, lavado de activos, financiamiento del terrorismo y demás), según lo exige el articulo 67 del Código de Procedimiento Penal (Ley 906 de 2004 y las que la modifiquen o deroguen).

51. Conforme lo exige el artículo 93 de la Ley 418 de 1997 (prorrogada por la Ley 1106 de 2006), terminar unilateralmente los subcontratos que celebre en desarrollo del Contrato, cuando establezca que el subcontratista incurrió en alguna de las conductas descritas en el Parágrafo de la Cláusula de Terminación Anticipada del Contrato. Igualmente deberá terminarlos cuando se lo solicite ECOPETROL S.A., el Fiscal General de la Nación o el Procurador General de la Nación, en razón de que se establezca la ocurrencia de los hechos a que se ha hecho referencia.

Cuando, sin justa causa, el CONTRATISTA no dé por terminado unilateralmente el subcontrato, o cuando no atienda la solicitud que en tal sentido le formule ECOPETROL S.A., el Fiscal o el Procurador, habrá lugar a la aplicación de la Cláusula Penal de Apremio prevista en el Contrato, y, si es del caso, a declarar su caducidad.

La terminación unilateral a que hace referencia el presente numeral, no requerirá decisión judicial ni dará lugar al pago de indemnización de perjuicios.

ECOPETROL S.A. podrá también solicitar al CONTRATISTA dar por terminados los subcontratos que éste celebre, por hechos adicionales a los previstos en el Parágrafo de la Cláusula de Terminación Anticipada del Contrato, los cuales tengan que ver con el apoyo y financiación al terrorismo.

52. Cumplir a cabalidad con las disposiciones legales sobre prevención y control de lavado de activos y financiación del terrorismo (LAFT) que le sean aplicables, implementando con eficiencia y oportunidad las políticas y los procedimientos necesarios para tal fin.

53. No subcontratar ni realizar operaciones con personas o entidades cuyos recursos provengan de actividades ilicitas de las contempladas en el Código Penal Colombiano o en cualquier norma que lo sustituya, adicione, o modifique, o que se encuentren relacionadas con dichas actividades.

54. Cumplir con los compromisos comerciales que, para la ejecución de este Contrato, haya adquirido con proveedores de bienes y servicios y/o subcontratistas (si los DPS le permiten subcontratar o ECOPETROL lo autoriza de manera expresa, por escrito).

55. Ejecutar todas las obligaciones que se deriven de la naturaleza de este Contrato, las que se consignen en otras cláusulas del mismo y las que se desprendan del Código de Comercio y el Código Civil.

56. Cumplir el Código de Ética de ECOPETROL y las Directrices de Responsabilidad Social Empresarial en la Contratación y Subcontratación.

57. Condiciones técnicas adicionales que el CONTRATISTA debe observar, de acuerdo con las condiciones especificas del servicio u obra que el CONTRATISTA deba ejecutar.

58. La metodología para la inspección de los equipos se acordará mediante una reunión que concreta el procedimiento de coordinación al inicio de cada orden de trabajo

59. EI CONTRATISTA se obliga a dar acatamiento a las directrices y compromisos sociales del área, dentro de los limites que haya fijado para ello ECOPETROL.

60. Los aspectos técnicos y económicos de la actividad contratada son aquellos expresados en los siguientes documentos, que se incorporan como parte integral del presente contrato:

- Condiciones Especificas de Contratación CEC y sus anexos emitidos por ECOPETROL S.A. en el proceso de selección.

61. Suministrar alimentación y transporte a su personal vinculado por contrato de trabajo con dedicación exclusiva a los que aplica la Tabla de niveles salariales para actividades contratadas no propias de industria del petróleo. La alimentación debe suministrarse en el lugar de ejecución del contrato y el transporte desde su residencia al sitio de trabajo y viceversa. 
CONTRATO N MA-0018531

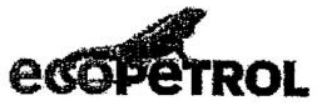

En Bogotá y en las áreas donde no sea posible el suministro del transporte y alimentación en especie, circunstancia que debe ser motivada por el contratista, ECOPETROL verificará la posibilidad de autorizar su compensación en dinero, asi:

Transporte: equivalente al subsidio mensual legal del transporte de acuerdo al año de vigencia del contrato.

Alimentación: equivalente al pago de un auxilio diario de $\$ 9.545$.

Nota: Estos valores no tienen incidencia salarial.

\section{CLAUSULA SEPTIMA.-OBLIGACIONES DEL CONTRATISTA EN MATERIA DE HSE}

EI CONTRATISTA se obliga a cumplir con todas las condiciones, previsiones y obligaciones contenidas en el Anexo denominado "Obligaciones del Contratista en materia de HSE", el cual declara conocer y acepta que hace parte integral del presente Contrato.

\section{CLAUSULA OCTAVA.-OBLIGACIONES DE ECOPETROL}

Para la ejecución del Contrato, ECOPETROL. S.A.se obliga a:

1) Entregar al CONTRATISTA, en la fecha de suscripción del Acta de Inicio del Contrato ylo en las fechas de inicio de cada una de las órdenes de trabajo, la información técnica y demás información requerida para la ejecución de los trabajos.

2) Tramitar y efectuar los pagos al CONTRATISTA dentro de los términos establecidos.

3) Emitir la solicitud de los Requerimientos de Trabajo, conforme al procedimiento señalado en el Anexo No.7 "Alcance y Especificaciones Técnicas" de los DPS.

4) Facilitar oportunamente el acceso a la información requerida por el CONTRATISTA para la ejecución del Contrato y/o cada orden de trabajo, de acuerdo con lo pactado.

5) Evaluar el desempeño del CONTRATISTA de conformidad con lo establecido en el Procedimiento de Gestión de Contratistas y en la metodología que obra como anexo de los DPS.

6) Tramitar los permisos necesarios para el ingreso del personal del CONTRATISTA al interior de las instalaciones de ECOPETROL S.A.

7) Las demás que se deriven de la naturaleza del Contrato que se celebre, las que se consignen en otras cláusulas del mismo, y las que se desprendan de la ley y que resulten aplicables.

\section{CLÁUSULA NOVENA.-PERSONAL}

1. Todas las instrucciones, observaciones y notificaciones que el Gestor del Contrato, en desarrollo de sus funciones, le imparta a quien el CONTRATISTA hubiere designado como su representante o interlocutor en el desarrollo del Contrato, se entenderán como hechas por ECOPETROL S.A. al CONTRATISTA.

2. Todos los documentos que suscriba la persona designada por el CONTRATISTA como su representante o interlocutor frente a ECOPETROL S.A. con ocasión de la ejecución del Contrato, tendrán tanta validez como si hubieran sido emitidos por el propio CONTRATISTA.

3. En caso de que el CONTRATISTA requiera sustituir alguno(s) de los integrantes del Equipo de Trabajo (personal) que fue objeto de evaluación durante el PS (para cumplimiento de requisitos mínimos o para la documento contractual, deberá solicitarlo a través de escrito dirigido al Gestor Administrativo de Contrato en el cual indique, como minimo:

a) Cuál es la persona que requiere sustituir;

b) Nombre, títulos y experiencia de la persona propuesta para ocupar el cargo del sustituido, y 


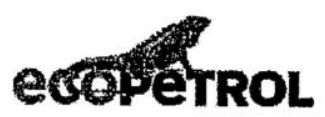

c) El escrito debe estar acompañado de la documentación soporte que permita verificar información contenida en aquel.

Para que ECOPETROL S.A. autorice la sustitución en cuestión, el personal reemplazante deberá reunir, cuando menos, las mismas caracteristicas del que fue objeto de evaluación y que va a ser reemplazado, es decir, debe cumplir con todos los requisitos mínimos y obtener el mismo puntaje que el obtenido por la persona a reemplazar, de ser evaluado de conformidad con las CEC, o cumplir con los requisitos estipulados para el perfil en cuestión.

El Gestor Administrativo del Contrato se pronunciará por escrito en relación con las solicitudes de sustitución de personal dentro de los cinco (5) días hábiles siguientes a la radicación de la totalidad de la información requerida en el Contrato para autorizar la sustitución en cuestión.

$\mathrm{Si}$ el Gestor Administrativo del Contrato no se pronuncia dentro de dicho plazo, se entenderá que aceptó la solicitud de sustitución de personal. Si el Gestor Administrativo del Contrato se niega a autorizar la sustitución, deberá indicar las razones.

4. El personal del CONTRATISTA no tiene ni adquirirá, por razón de la ejecución del Contrato, vínculo laboral alguno con ECOPETROL S.A. Toda la responsabilidad derivada de los contratos de trabajo correrá a cargo exclusivo del CONTRATISTA.

5. El CONTRATISTA, al seleccionar y vincular el personal con el cual ejecutará el Contrato, deberá tener en cuenta que ECOPETROL S.A. podrá abstenerse de dar permiso de acceso a sus instalaciones industriales, a personas que hallándose bajo la influencia de licor, drogas o sustancias alucinógenas, hubieran provocado incidentes 0 accidentes en aquellas.

6. ECOPETROL S.A. se reserva el derecho de ser el único que pueda determinar si cualquiera de los ingenieros o técnicos del CONTRATISTA está o no adecuadamente capacitado y el CONTRATISTA se compromete a reemplazarlo en cuanto el representante de ECOPETROL S.A. asil lo solicite, todo ello de acuerdo con los requisitos minimos de experiencia contenidos en los DPS.

7. Dotar a todo el personal a su cargo de los elementos estipulados en la normatividad de seguridad industrial (guantes, botas, uniformes, impermeables, cascos, respiradores, protectores auditivos, mascarillas, arneses, etc.), en caso que se requieran visitas de campo.

8. EI CONTRATISTA está obligado a prestar el servicio médico a sus trabajadores en la siguiente forma: a) A través del Instituto de Seguros Sociales o EPS en los sitios en los cuales estas entidades prestan servicios. En este caso deberá asumir la cuota establecida por la ley. b) Prestación directa del servicio médico en los sitios donde el Instituto de Seguro Social o EPS no presten este servicio. ECOPETROL S.A.no considerará el personal del CONTRATISTA apto para realizar los trabajos, sin la correspondiente certificación de la afiliación al sistema de seguridad social.

PARÁGRAFO: EI CONTRATISTA autoriza a ECOPETROL para que, en caso de que no efectúe oportunamente el pago de cualquiera de las obligaciones (laborales, relativas al Sistema de Seguridad Social Integral y parafiscales, $u$ otras) a cargo de aquél en relación con el personal que ocupe en la ejecución del Contrato, o de obligaciones adquiridas con Subcontratistas y/o proveedores con quienes hubiere establecido relaciones para la ejecución del objeto del Contrato (en tanto se tenga certeza sobre su existencia y exigibilidad) ECOPETROL descuente y pague las sumas correspondientes de los saldos a favor del CONTRATISTA. Dicha autorización comporta una cesión anticipada (desde la firma del Contrato) a favor de ECOPETROL de los dineros en cuestión, a efectos de que pueda disponer de los mismos.

De las sumas retenidas, ECOPETROL pagará directamente a los trabajadores las acreencias laborales y realizará los pagos por concepto de aportes a los sistemas de salud, riesgos profesionales, pensiones y a las Cajas de Compensación Familiar, Instituto Colombiano de Bienestar Familiar y Servicio Nacional de Aprendizaje. Lo anterior, en concordancia con lo señalado en este Parágrafo y en cumplimiento del articulo 50 de la Ley 789 de 2002.

\section{CLÁUSULA DÉCIMA - GARANTIAS Y SEGUROS}

Dentro de los cinco (5) dias hábiles siguientes a la suscripción del Contrato, el CONTRATISTA deberá constituir por su cuenta, ante una compañila de seguros legalmente autorizada para funcionar en Colombia, entregar a ECOPETROL

1. Una Garantia de Cumplimiento otorgada a favor de ECOPETROL S.A., que se rija por el Clausulado General de la Garantia Única de Cumplimiento anexo, y que contenga los siguientes amparos: 


\section{CONTRATO N MA-0018531}

\section{ecopêtrol}

a) De Cumplimiento de las obligaciones emanadas del Contrato, que garantice el cumplimiento de todas y cada una de las obligaciones a cargo del CONTRATISTA, el pago de la cláusula penal de apremio y de la cláusula penal pecuniaria, y que tenga:

- Un valor asegurado igual a $\operatorname{COL} \$ 100.000 .000$, y

- Una vigencia igual al término de vigencia del Contrato y un (1) mes más. Es decir: la vigencia de la póliza debe ser igual a la sumatoria del plazo de ejecución, más el plazo de liquidación de mutuo acuerdo, más un (1) mes.

2. Seguros:

Adicionalmente y dentro del mismo término el CONTRATISTA deberá constituir y entregar a ECOPETROL S.A. los siguientes seguros:

a) Un seguro de Responsabilidad Civil Extracontractual, por un valor asegurado de COL $\$ 100.000 .000$ pesos colombianos, equivalente, con una vigencia igual a la del plazo de ejecución del Contrato. ECOPETROL S.A. debe figurar como asegurado y beneficiario adicional.

Adicional a lo anterior, para cada orden de trabajo (acorde a lo que se indique en el texto de la misma) dentro de los cinco (5) días hábiles siguientes a la notificación de la misma, el CONTRATISTA deberá constituir por su cuenta, ante una compañía de seguros legalmente autorizada para funcionar en Colombia, y entregar a ECOPETROL S.A.:

1. Una Garantia de Cumplimiento otorgada a favor de ECOPETROL S.A., que se rija por el Clausulado General de la Garantia Única de Cumplimiento anexo, y que contenga los siguientes amparos:

a) De Cumplimiento de las obligaciones emanadas del Contrato, que garantice el cumplimiento de todas y cada una de las obligaciones a cargo del CONTRATISTA, el pago de la cláusula penal de apremio y de la cláusula penal pecuniaria, y que tenga:

- Un valor asegurado igual al $10 \%$ del valor estimado de la orden de trabajo emitida, y

- Una vigencia igual al término de vigencia de la orden de trabajo y un (1) mes más. Es decir: la vigencia de la póliza debe ser igual a la sumatoria del plazo de ejecución, más el plazo de liquidación de mutuo acuerdo de la orden de trabajo, más un (1) mes.

b) De pago de salarios, prestaciones sociales e indemnizaciones laborales al personal vinculado para la ejecución del Contrato, que tenga:

Un valor asegurado igual al $5 \%$ del valor estimado de la orden de trabajo, y

- Una vigencia igual al término de vigencia de la orden e trabajo y tres (3) años más. Es decir: la vigencia del amparo debe ser igual a la sumatoria del plazo de ejecución, más el plazo de liquidación de mutuo acuerdo de la orden de trabajo, más tres (3) años.

c) De calidad de los servicios, que tenga:

- Un valor asegurado igual al $10 \%$ del valor final de la orden de trabajo, y

Una vigencia que comprenda el plazo de liquidación de la orden de trabajo de común acuerdo y un (1) año más, contada desde la fecha de terminación de la orden de trabajo.

d) De estabilidad de la obra, que tenga:

- Un valor asegurado igual al $10 \%$ del valor final de la orden de trabajo, y

Una vigencia de cinco (5) años contados a partir de la fecha de terminación de la orden de trabajo.

e) De correcto funcionamiento de los equipos suministrados, vendidos, instalados, reparados por el CONTRATISTA, que tenga:

- Un valor asegurado igual al $10 \%$ del valor estimado de la orden de trabajo y.

- Una vigencia igual al término de vigencia de la orden de trabajo y un (1) mes más. Es decir: la vigencia del amparo debe ser igual a la sumatoria del plazo de plazo de ejecución, más el plazo de liquidación de mutuo acuerdo de la orden de trabajo, más un (1) mes. 


\section{CONTRATO N $^{\circ}$ MA-0018531}

\section{ecofertrol}

f) De buen manejo y cuidado de los bienes entregados por ECOPETROL. S.A. para la ejecución de la orden de trabajo, que tenga:

- Un valor asegurado igual al $10 \%$ del valor estimado de la orden de trabajo, y

- Una vigencia igual al término de vigencia de la orden de trabajo y un (1) mes más. Es decir: la vigencia del amparo debe ser igual a la sumatoria del plazo de plazo de ejecución, más el plazo de liquidación de mutuo acuerdo de la orden de frabajo, más un (1) mes.

2. Seguros:

Adicionalmente y dentro del mismo término el CONTRATISTA deberá constituir y entregar a ECOPETROL S.A. los siguientes seguros:

a) Un seguro de Responsabilidad Civil Extracontractual, por un valor asegurado equivalente al diez por ciento $(10 \%)$ del valor estimado de la orden de trabajo, con una vigencia igual a la del plazo de ejecución del Contrato. ECOPETROL S.A. debe figurar como asegurado y beneficiario adicional.

b) Seguro obligatorio de accidentes de tránsito SOAT, para todos los vehiculos automotores al servicio del Contrato, en caso de tener vehículos asignados al desarrollo del mismo.

c) Seguro de automóviles contra todo riesgo que ampare todos los vehiculos automotores al servicio del Contrato, en caso de tener vehículos asignados al desarrolio del mismo. Dicho seguro deberá tener como minimo las siguientes coberturas: responsabilidad civil extracontractual, pérdida parcial o total por daños, pérdida total o parcial por hurto, gastos de grúa, transporte y protección del vehículo accidentado, temblor, terremoto, erupción volcánica, amparo patrimonial, asistencia jurídica en proceso penal y en proceso civil.

d) Suscribir una póliza de Seguro Colectivo de Vida que ampare a los trabajadores vinculados para la ejecución del CONTRATO frente a los riesgos de muerte, accidentes, incapacidad por accidente de trabajo o enfermedad profesional y riesgo común que cubra la diferencia entre las prestaciones establecidas en el régimen convencional de ECOPETROL. S.A. y lo establecido en el Sistema de Seguridad Social integral por el término de vigencia del contrato.

PARAGRAFO PRIMERO: Para efectos de constitución de estas pólizas para las órdenes de trabajo, en cada una de ellas se establecerá las garantias y seguros individuales según su naturaleza acorde a la matriz de pólizas que se consigna en el Anexo No. 35 del contrato (Manual de entendimiento).

\section{PARAGRAFO SEGUNDO: Disposiciones comunes a las garantías y seguros.}

a) Las pólizas deben contener una estipulación expresa en la que se manifieste que toda solicitud de cancelación, modificación o renovación a los términos consignados en las mismas, formulada por el CONTRATISTA a la compañia aseguradora, debe contar con el visto bueno por escrito de ECOPETROL S.A. para poder ser tramitada.

b) Si se estableció que las garantias o seguros se deben tomar en dólares, en la póliza se debe consignar que serán pagaderas(os) en pesos colombianos a la tasa representativa del mercado vigente certificada por la Superintendencia Financiera para la fecha en que se efectúe el pago de la indemnización correspondiente.

c) Las carátulas deben contener en forma clara y expresa el alcance y monto del riesgo amparado.

d) EI CONTRATISTA deberá reponer las garantias o seguros cuando el valor de los mismos se vea afectado por razón de siniestros.

e) En el evento en que se aumente el valor del Contrato o se prorrogue su vigencia, el CONTRATISTA deberá ampliar o prorrogar las correspondientes garantias y seguros.

f) Los costos por la expedición de las garantías y seguros, sus adiciones o prórrogas, serán exclusivamente a cargo del CONTRATISTA, quien puede negociar los deducibles correspondientes según su conveniencia.

PARAGRAFO TERCERO: EI CONTRATISTA podrá optar por constituir una garantía bancaria o una carta de crédito "Stand-by; en tal caso entregará a ECOPETROL S.A. una o más cartas de crédito "Stand-by" irrevocables o garantias bancarias expedidas por una institución financiera aceptada por ECOPETROL S. A que tenga representación, o un banco confirmador y pagador en Colombia , para garantizar el cumplimiento de las obligaciones contenidas en el Contrato por una cantidad (en dólares de los Estados Unidos de América 
CONTRATO N MA-0018531

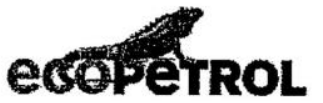

o en pesos colombianos) equivalente al $10 \%$ del valor global o estimado del Contrato (según lo pactado en la Minuta). La garantía deberá estar vigente por un térmíno que comprenda el plazo de ejecución, el plazo de liquidación del Contrato de mutuo acuerdo y un (1) mes más. Las cartas de crédito "Stand-by" o garantias bancarias que se expidan para garantizar el cumplimiento del Contrato, deben ser irrevocables y garantias a primer requerimiento o primera demanda.

En el caso de instituciones financieras locales, en la garantía debe constar expresamente que el emisor renuncia al beneficio de excusión contemplado en el artículo 2383 del Código Civil.

ECOPETROL S.A. aceptará las cartas de crédito "Stand-by" o garantías bancarias que se expidan conforme a las Reglas y Usos Uniformes relativos a créditos Documentarios (Uniform Customs and Practice for Documentary Credits - UPC), revisión de 2007, Publicación $\mathrm{N}^{\circ} 600$ de la Cámara de Comercio Internacional.

\section{CLÁUSULA DECIMA PRIMERA - IMPUESTOS}

Todos los impuestos que se causen por razón de la suscripción, desarrollo, ejecución y liquidación del Contrato y/o cada una de sus órdenes de trabajo, con excepción de los que estrictamente correspondan a ECOPETROL S.A., son de cargo exclusivo del CONTRATISTA. ECOPETROL S.A. no ror alguna por impuestos, así éstos fueren establecidos con posterioridad al vencimiento del plazo de presentación de propuestas y celebración del Contrato y siempre y cuando en las CEC no se establezca algo diferente.

En materia de Impuestos, ECOPETROL S.A. efectuará a las cuentas o facturas del CONTRATISTA las retenciones que establezca la ley.

El Impuesto al Valor Agregado -IVA- estará a cargo de ECOPETROL S.A., y se liquidará y pagará sobre la base gravable y la cuantia establecida por la ley.

Las devoluciones o exenciones a que crea tener derecho el CONTRATISTA deberán ser tramitadas por éste ante la respectiva Administración de Impuestos, sin responsabilidad alguna por parte de ECOPETROL S.A. costo para la Sociedad.

\section{CLAUSULA DECIMA SEGUNDA. - CLAUSULA PENAL DEAPREMIO}

Por el hecho de suscribir el Contrato, el CONTRATISTA acepta y autoriza expresamente que en caso de que no realice alguna de las actividades a su cargo, o la realice de manera diferente a como fue pactado o a normas técnicas que apliquen, o por fuera de los plazos acordados o de los previstos en la ley, ECOPETROL le descuente de los saldos a su favor o de cualquier suma que le fuere debida por esta Sociedad, la suma o porcentaje a descontar corresponderá a

1. Cero punto setenta y cinco por ciento $(0.75 \%)$ del valor de la Orden de trabajo, cuando dicho incumplimiento se relaciones con i) Especificaciones técnicas o normas técnicas; ii) tiempos contractuales de cumplimiento; iii) incumplimientos laborales; iv) Desfase superior al $10 \%$ rempos del PDT o $5 \%$ frente a actividades criticas del PDT; v) EI CONTRATISTA subcontrate respecto Contrato sin la autorización previa, expresa y escrita de ECOPETROL.

Sin perjuicio de procedencia frente al incumplimiento de otras obligaciones que se consignen en los DPS y que se presenten durante la vigencia del Contrato, darán lugar al descuento a que se refier esta Cláusula, EI CONTRATISTA subcontrate o ceda el Contrato sin la autorización previa, expresa y escrita de ECOPETROL El descuento procederá por cada situación o hecho que lo motive, o por cada dia en que el mismo se prolongue hasta un máxima con cada situación o hecho; y se hará efectivo con cargo a la factura siguiente a aquel en que le fuere comunicado por el Administrador del Contrato, o a los saldos que existieren del mismo.

2. Cualquier otro incumplimiento de las obligaciones pactadas en el contrato, tendrá un apremio equivalente a cero punto cuatro por ciento $(0.4 \%)$ del valor acumulado de las ordenes de trabajo libradas por ECOPETROL a la fecha del incumplimiento, EI descuento procederá por cada situací́ o hecho que lo motive, o por cada día en que el mismo se prolongue hasta un máximo cada situación días continuos en relación con cada situación o hecho; y se hará efectivo con cargo a la factura 


\section{CONTRATO N MA-0018531}

\section{edorthol}

siguiente a aquel en que le fuere comunicado por el Administrador del Contrato, o a los saldos que existieren del mismo.

En caso de no haberse librado ninguna orden de trabajo, el valor del apremio corresponderá a la suma de siete millones quinientos mil pesos colombianos (7.500.000), El descuento procederá por cada situación o hecho que lo motive, o por cada día en que el mismo se prolongue hasta un máximo de quince (15) dias continuos en relación con cada situación o hecho; y se hará efectivo con cargo a la factura siguiente a aquel en que le fuere comunicado por el Administrador del Contrato, o a los saldos que existieren del mismo.

Para que el descuento opere se surtirá el siguiente procedimiento:

(i) El Gestor del Contrato comunicará por escrito al CONTRATISTA el hecho presentado.

(ii) Recibida la comunicación, dentro de los tres (3) dias hábiles siguientes, el CONTRATISTA podrá indicar las razones por las cuales estima que no tiene responsabilidad en relación con el hecho comunicado.

(iii) El Administrador del Contrato analizará las explicaciones suministradas por el CONTRATISTA; y, de resultar aceptables, se lo hará saber a éste; en caso contrario le comunicará que se procederá al descuento previsto en ésta Cláusula (igual comunicación se dará en caso de que el CONTRATISTA no indique razón alguna).

Si no existen saldos a favor del CONTRATISTA para descontar las sumas que resulten de la aplicación de esta Cláusula, las mismas se harán efectivas con cargo al amparo de cumplimiento de la garantia respectiva. Si ni lo uno ni lo otro fuere posible, ECOPETROL las cobrará por la via ejecutiva, para lo cual el Contrato, junto con las comunicaciones a través de las cuales se agota el procedimiento previsto en esta Cláusula,

prestará mérito de título ejecutivo. Contrato, ni se eximirá al CONTRATISTA de la indemnización de los perjuicios correspondientes, ni se impedirá a ECOPETROL efectuar registros negativos sobre el desempeño del CONTRATISTA, los cuales se podrán consignar en la respectiva certificación de experiencia.

\section{CLAUSULA DECIMA TERCERA. PENAL PECUNIARIA}

De acuerdo con lo establecido en la CLAUSULA 22 PENAL PECUNARIA de las CONDICIONES GENÉRICAS DE LA CONTRATACIÓN CGC.

\section{CLAUSULA DECIMA CUARTA-CESIÓN Y SUBCONTRATACION}

\section{EI CONTRATISTA no podrá:}

1. Ceder total o parciaimente el Contrato a persona alguna sin previa autorización expresa y escrita de ECOPETROL.

2. Subcontratar la ejecución de una o varias de las actividades a su cargo, salvo que ECOPETROL lo autorice de manera previa, expresa, por escrito, caso en el cual se debe dar aplicación al Procedimiento de Responsabilidad Social Empresarial en la Contratación y Subcontratación. La subcontratación no autorizada de manera previa, expresa y por escrito, además de conilevar un incumplimiento contractual, no será oponible para ningún efecto a ECOPETROL, ni por el CONTRATISTA ni por el subcontratista.

PARÁGRAFO: EI CONTRATISTA no podrá subcontratar ni ceder el Contrato a personas o entidades cuyos recursos provengan de actividades ilícitas de las contempladas en el Código Penal Colombiano o en cualquier norma que lo sustituya, adicione, o modifique, o que se encuentren relacionadas con dichas actividades Autorizada y efectuada la subcontratación o cesión, el subcontratista o el cesionario deberán cumplir/a cabalidad con las disposiciones legales sobre prevención y control de lavado de activos y financiación/del cabalidad con las disposiciones legales sobre prevención y control de lavado de activos y financiaciónder
terrorismo (LAFT) que le sean aplicables, implementando con eficiencia y oportunidad las políticas y los procedimientos necesarios para tal fin. 
CONTRATO N MA-0018531

\title{
ecopetrol
}

\section{CLAUSULA DECIMA QUINTA - DOMICILIO CONTRACTUAL, LEY} Y JURISDICCIÓN APLICABLE

\begin{abstract}
El domicilio contractual, para todos los fines legales y procesales, será la ciudad de Bogotá, la cual no se entenderá como base del ejercicio contractual.

Para todos los efectos, el presente Contrato se regirá por las leyes de la República de Colombia.

En lo relativo a las diferencias que surjan en cuanto a las obligaciones y derechos originados en el presente Contrato, el CONTRATISTA de manera expresa manifiesta que las mismas se someterán a la jurisdicción colombiana, y renuncia a intentar reclamación diplomática, salvo el caso de denegación de justicia.
\end{abstract}

\section{CLÁUSULA DECIMA SEXTA - SOLUCIÓN DE CONFLICTOS}

En el caso de diferencias, conflictos o disputas relacionados con la interpretación, ejecución y aplicación de este Contrato, las Partes procurarán acudir a los mecanismos alternativos de solución de conflictos regulados legalmente.

\section{CLÁUSULA DECIMA SEPTIMA.-OTROS CONTRATOS}

ECOPETROL S.A. se reserva el derecho de suscribir y ejecutar otros Contratos que tengan relación con el objeto de este Contrato. El CONTRATISTA deberá entonces darle la colaboración necesaria a ECOPETROL S.A. y a los contratistas de ECOPETROL S.A. trabajando en el Lugar de Ejecución, para asegurar donde sea necesario que todas las partes del servicio que se están llevando a cabo, se integren adecuadamente con otros materiales, equipos y servicios suministrados por ECOPETROL S.A. o por un contratista de éste, y para que el programa general de ECOPETROL S.A. se cumpla.

En el evento en que el CONTRATISTA tenga alguna queja acerca de la falta de cooperación de los otros contratistas (distintos a los que él es responsable) en el Lugar de Ejecución, este deberá inmediatamente informar a ECOPETROL S.A. por escrito, sobre el particular para que ECOPETROL S.A. determine las acciones a seguir.

\section{CLAUSULA DECIMA OCTAVA.-NOTIFICACIONES}

Todos los avisos, solicitudes, comunicaciones o notificaciones que las Partes deban dirigirse en virtud de este Contrato, se efectuarán por escrito y se considerarán realizadas desde el momento en que el documento correspondiente sea radicado en la dirección que a continuación se indica.

\section{CONTRATISTA}

$\begin{array}{ll}\begin{array}{l}\text { Dirección } \\ \text { Teléfono } \\ \text { e-mail }\end{array} & \begin{array}{l}\text { Calle 25 No. 39-30 Bogotá. } \\ \text { (571) 7442525 Ext. 218 } \\ \text { licitaciones@obrasydisenos.com.co }\end{array} \\ \text { ECOPETROL S.A. } & \text { (Gestor Administrativo) } \\ \begin{array}{l}\text { Dirección } \\ \text { Teléfono } \\ \text { e-mail }\end{array} & \begin{array}{l}\text { CAT Cúcuta - Norte de Santander } \\ \text { 2344000 ext. 40361 }\end{array} \\ & \text { Edgar.amado@ecopetrol.com.co }\end{array}$

ECOPETROL S.A. (Administrador) 


\title{
CONTRATO N MA-0018531
}

\section{ectopetroL}

\author{
Dirección Calle 37 \# 8-43 Piso 9 Edificio Colgás Bogotá. \\ Teléfono 2344000 ext. 50832 \\ e-mail Ciro.castaneda@ecopetrol.com.co
}

Las comunicaciones enviadas via fax se considerarán como cursadas una vez recibido el mensaje de comunicación exitosa de la máquina en donde se origina el envio de ésta.

En constancia, se firma el presente documento en Bogotá D.C., a los seis (06) dias del mes de noviembre de 2012.

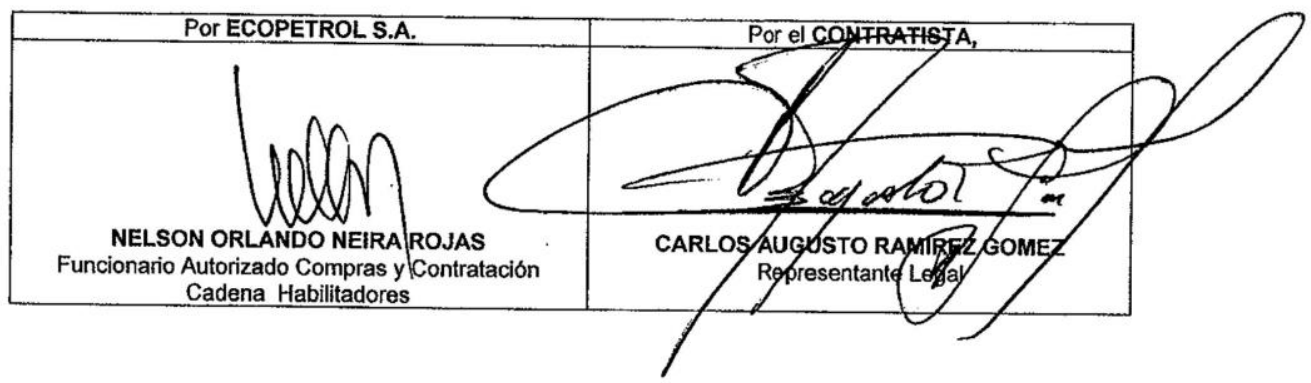

